\title{
Combustion and Gasification Characteristics of Chars From Four Commercially Significant Coals of Different Rank
}

\author{
EPRI AP.2601 \\ Research Project 1654-6 \\ Final Report, September 1982 \\ Prepared by \\ COMBUSTION ENGINEERING, INC. \\ Power Systems Division \\ Kreisinger Development Laboratory \\ 1000 Prospect Hill Road \\ Windsor, Connecticut 06095 \\ Program Manager \\ G. J. Goetz \\ Principal Investigators \\ N. y. Nsakala \\ R. L. Patel \\ T. C. Lao
}

\section{NOTICE}

PORTIONS OF THIS REPORT ARE ILLEGIBLE, It

has been reproduced from the best available copy to permit the broadest possible availability.

\section{Prepared for}

Electric Power Research Institute

3412 Hillview Avenue

Palo Alto, California 94304

EPRI Project Manager

G. H. Quentin

Clean Gaseous Fuels Program Advanced Power Systems Division
This document is PUBLICLY RELEASABLE Bam Stealo Authorizing Official

Date: $4-19-17$

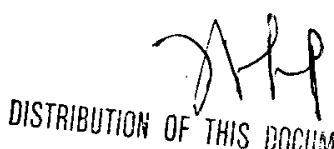

DISTRIBUTIOA OF THIS DOCUAERT IS UMULARTED 


\section{DISCLAIMER}

This report was prepared as an account of work sponsored by an agency of the United States Government. Neither the United States Government nor any agency Thereof, nor any of their employees, makes any warranty, express or implied, or assumes any legal liability or responsibility for the accuracy, completeness, or usefulness of any information, apparatus, product, or process disclosed, or represents that its use would not infringe privately owned rights. Reference herein to any specific commercial product, process, or service by trade name, trademark, manufacturer, or otherwise does not necessarily constitute or imply its endorsement, recommendation, or favoring by the United States Government or any agency thereof. The views and opinions of authors expressed herein do not necessarily state or reflect those of the United States Government or any agency thereof. 


\section{DISCLAIMER}

Portions of this document may be illegible in electronic image products. Images are produced from the best available original document. 


\section{ORDERING INFORMATION}

Requests for copies of this report should be directed to Research Reports Center (RRC), Box 50490, Palo Alto, CA 94303, (415) 965-4081. There is no charge for reports requested by EPRI member utilities and affiliates, contributing nonmembers, U.S. utility associations, U.S. government agencies (federal, state, and local), media, and foreign organizations with which EPRI has an information exchange agreement. On request, RRC will send a catalog of EPRI reports.

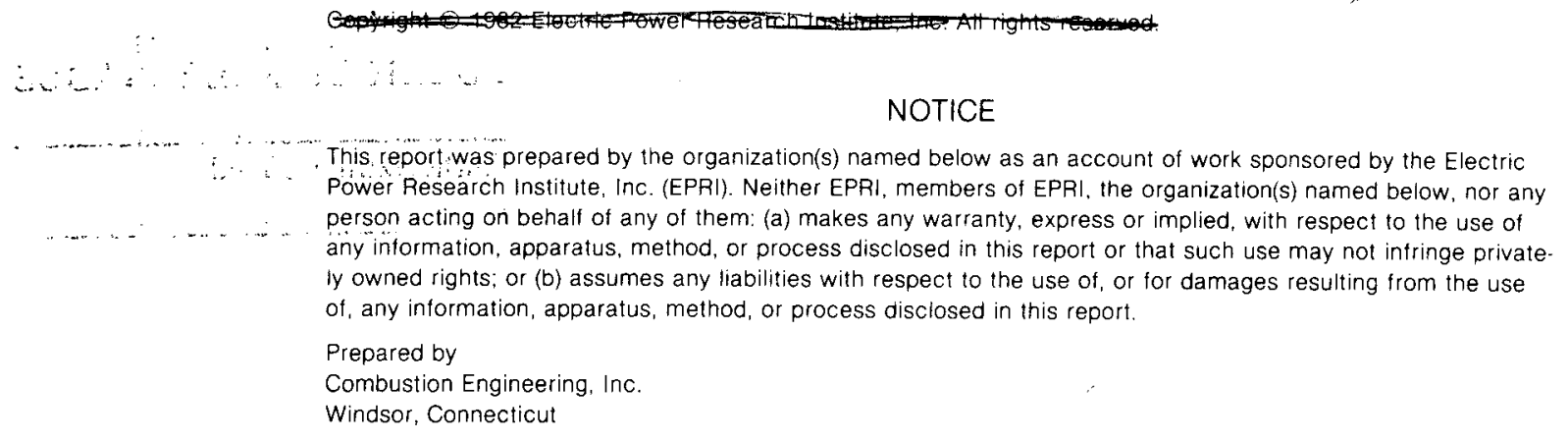


ABSTRACT

The combustion and gasification kinetics of four size graded coal chars were investigated experimentally in Combustion Engineering's Drop Tube Furnace System (DTFS). The chars were prepared in the DTFS from commercially significant coals representing a wide range of rank; these included a Pittsburgh No. 8 Seam hvAb coal, an Illinois No. 6 Seam huCb coal, a Wyoming Sub C, and a Texas Lignite A. Additionally, a number of standard ASTM and special bench scale tests were performed on the coals and chars to characterize their physicochemical properties.

Results showed that the lower rank coal chars were more reactive than the higher rank coal chars and that combustion reactions of chars were much faster than the corresponding gasification reactions. Fuel properties, temperature, and reactant gas partial pressure had a significant influence on both combustion and gasification, and particle size had a mild but discernible influence on gasification.

Fuel reactivities were closely related to pore structure. Computer simulation of the combustion and gasification performances of the subject samples in the DTFS supported the experimental findings. 
$\ominus$

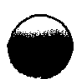




\section{EPRI PERSPECTIVE}

\section{PROJECT DESCRIPTION}

This final report for RP1654-1, entitled Combustion and Gasification Characteristics of Chars From Four Commercially Significant Coals of Different Rank, describes a bench-scale experimental study of chemical kinetics with an entrained flow reactor. This project was originally intended to provide background and support for the test program (under RP244) involving the Combustion Engineering, Inc., (C-E) atmospheric entrained gasifier at the 120-ton-per-day process development unit (PDU) in Windsor, Connecticut. However, by determining key reaction parameters for a wide range of coal chars, the study also provides valuable results of broad interest. For example, this information should be directly applicable for engineering analysis of entrained flow gasification reactors, in general, using detailed computer simulation models such as those developed under RP1037 and reported in EPRI Final Report AP-1179, Volume 1.

Additionally, the pyrolys is of coal in the bench-scale reactor during this study was analyzed by Advanced Fuel Research, Inc., using Fourier transform infrared (FTIR) spectroscopy under RP1654-7 and reported in EPRI Final Report AP-2602.

Taken together, these related studies provide a complementary treatment of the dominant coal reactions that occur in a large-scale gasifier.

\section{PROJECT OBJECTIVES}

The original objective was to determine the combustion and gasification characteristics of coals and chars from the C-E/PDU gasifier in both bench-scale and pilotscale reactors. These experimental results, in turn, were to form the basis for evaluating the performance of various coals and chars in the POU gasifier.

Unfortunately the PDU gasifier test program was discontinued before this study could be completed. This led to a change in objectives whereby the larger pilot-scale laboratory reactor study was abandoned for lack of sufficient quantities of PDU char 
as feedstock. Instead, a more comprehensive program of testing on the bench-scale flow reactor, or drop-tube furnace system (DTFS), was adopted. Chars for the alternate study were to be prepared in the DTFS from four coals of differing rank, including Texas lignite A coal, Wyoming subbituminous $C$ coal, and $I 1$ linois No. 6 hvCb and Pittsburgh No. 8 hvab bituminous coals. In addition to the studies of combustion, gasification, and pyrolysis kinetics in the entrained flow reactor DTFS, a number of supplementary bench-scale tests were to be made to measure the physicochemical properties of the coals and chars.

\section{PROJECT RESULTS}

These reaction rate studies indicate that gasification reactivity of char is inversely proportional to coal rank. For combustion, however, the three coals of lowest rank produced chars with comparable reactivity; this reactivity was much greater than that of the fourth, higher-rank Pittsburgh seam coal.

With respect to the larger C-E/PDU gasifier tests, such results imply that the decision to focus completely on Pittsburgh seam coal in that program may have contributed to the inability to fully achieve anticipated performance levels. For example, the PDU did not demonstrate suitable carbon conversion rates at design conditions. This generally created a sizable accumulation of unconverted coal char and product gas heating values that were lower than expected. The DTFS results suggest that this apparent inability to fully consume the recycled coal char in the first, or combustor, stage of the PDU may be tied strongly to the poor combustion features of the Pittsburgh coal feedstock. Furthermore, the relatively low gas heating values observed from the PDU may also be inferred from low rates of gasification of Pittsburgh coal in the DTFS reactor. There were undoubtedly other factors contributing to the overal1 PDU gasifier performance as we11. However, the PDU test program unfortunately did not accomplish its objective to test other coals as planned. In retrospect, if coals of lower rank (such as those reported here) had been tested in the PDU, many unresolved questions regarding gasifier performance might have been answered. In a more general sense, the importance of having a program of fundamental research in direct support of a larger gasifier development effort has been amply demonstrated.

The contribution of the results of this study to the overall data base on coal gasification reaction chemistry is also significant. Surveys of coal gasification reaction rate kinetics in the published literature indicate that data which are pertinent for commercial gasifier development are not readily available. Indeed, in many engineering analyses, it has often been necessary to use reaction parameters 
from old experiments with char from unrelated sources or with specimens that were not consistently prepared.

The use of the bench-scale DTFS entrained flow reactor also demonstrated significant advantages for such reaction studies. Much of the existing gasification rate data has been determined using thermogravimetric analysis (TGA). The typical TGA apparatus is essentially a small batch (nonflow) reactor that determines reaction rates by weight-loss measurements. By contrast the DTFS is a flow reactor in which coal or char particles are entrained in a gas stream composed of the chosen reaction environment (e.g., oxygen, carbon dioxide, and steam). The DTFS, therefore, emulates particle reaction conditions more like those in large entrained gasifiers. Such laboratory reactors also enable measurement of gas composition as evolved, which permits a component-specific determination of reaction rates as an alternative to weight-loss methods. For example, it has been possible to measure specifically the rate at which carbon monoxide is formed by gasifying carbon in char with carbon dioxide. Additionally, with the DTFS reactor, it is also possible to conduct in situ measurements of gas evolution using modern instruments, such as the FTIR technique being applied by Advanced Fuel Research in RP1654-8 and to be reported in EPRI Final Report AP-2603.

This report should be of special interest to those engineers and scientists involved in coal gasifier development and applications.

George H. Quentin, Project Manager

Advanced Power Systems Division 
•

• 1.

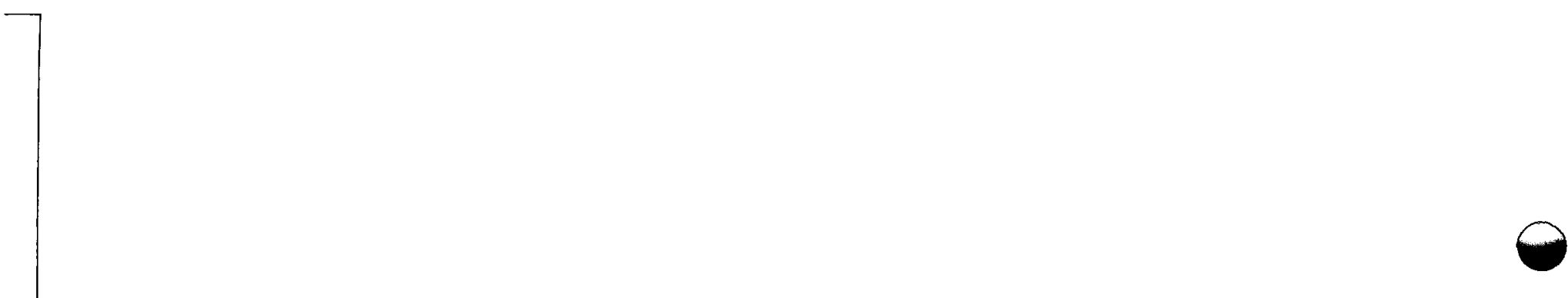

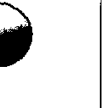


The work presented in this report was performed by Combustion Engineering, Inc., (C-E) under the Electric Power Research Institute (EPRI) Contract RP 1654-6. The work was carried out under the supervision of EPRI's Project Manager, Dr. George H. Quentin.

Testing was performed at C-E's Kreisinger Development Laboratory. Messrs. Dana R. Raymond and Donald J. Holeman of the Fuels Research Section conducted all the Drop Tube Furnace System tests. Messrs. Gilbert L. Hale, David E. Gaughan, Kurt W. Johnson, Alan J. Garvey, Joseph R. Fliss, Robert M. Eaton, and Douglas E. Sharpe of the Fuels Laboratory provided all the fuel analyses. Messrs. Tony Stathoplos, Carl R. Bozzuto, Richard W. Borio, M. Rao Gogineni, Frank T. Matthews, S. Ron Wysk, Cairn R. Russe11, Alan R. Griggs, and Dr. Robert W. Koucky provided constructive review of test procedures, data reduction techniques, and reports.

Finally the efforts of Mrs. JoEllen W. Allen and C-E's Secretarial Services are acknowledged. 
$\bullet$

$\bullet$ 1
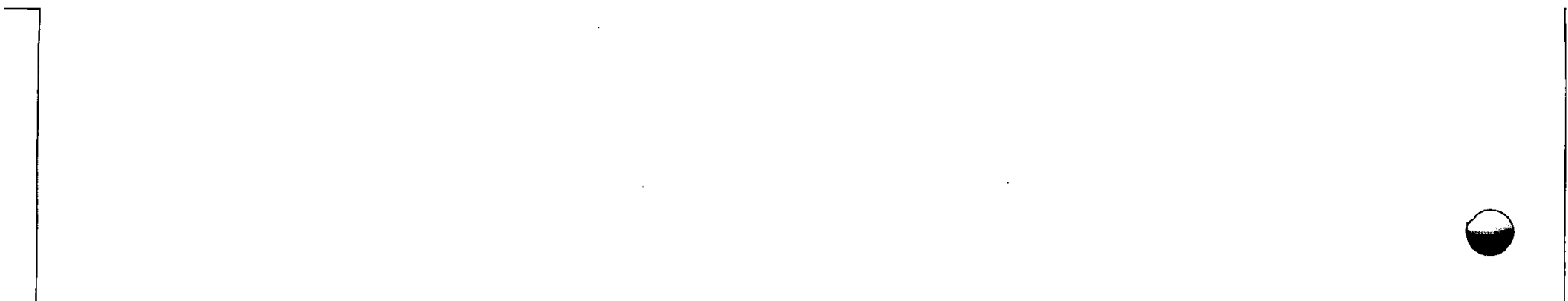


\section{CONTENTS}

Section

Page

SUMMARY, CONCLUSIONS, AND RECOMMENDATIONS S-1

1 INTRODUCTION 1-1

PDU Process 1-1

Summary of Previous Work $1-3$

Char Gasification $1-3$

Char Combustion $1-3$

Project Objective and Technical Approach 1-4

Selection of Parent Coals $1-4$

2 EXPERIMENTAL PROCEDURES 2-1

Characterization of Coal, Ash, and Char Samples 2-1

ASTM Techniques 2-1

Special Techniques 2-1

Flammability Index 2-1

Micro-Proximate Analyses 2-1

Specific Surface Areas 2-2

Thermo-Gravimetric Analyses 2-2

Combustion, Gasification, and Pyrolys is of Size Graded Coals

and Chars in the Drop Tube Furnace System (DTFS) 2-2

Test Matrix 2-2

Char Preparation 2-5

Sampling and Analysis 2-7

3 DROP TUBE FURNACE SYSTEM DATA REDUCTION PROGRAM 3-1

Ash Tracer Method 3-1

Carbon Monoxide Concentration Method 3-1

Char Combustion and Gasification Kinetics 3-2 
Characteristics of Coal, Char, and Ash Samples 4-1

Coal Analyses 4-1

Flammability Indices 4-1

Ash Analyses 4-1

Char Characteristics 4-3

Analyses 4-3

Particle Size Distributions 4-3

Pore Surface Areas 4-3

Thermo-Gravimetric Reactivities 4-7

Surface Area-Reactivity Relationships 4-10

Pyrolysis, Combustion, and Gasification of Coals and Chars

in the Drop Tube Furnace System (DTFS) 4-10

Pyrolysis of Coals and Char 4-10

Combustion of Coals 4-13

Combustion of Chars 4-18

Effect of Temperature 4-18

Effect of Fuel Properties 4-18

Effect of 0xygen Partial Pressure $\left(\mathrm{P}_{2}\right)$ 4-21

Kinetic Parameters 4-21

Gasification of Chars 4-28

Effect of Temperature 4-28

Effect of Fuel Properties 4-28

Effect of Particle Size 4-32

Effect of Carbon Dioxide Partial Pressure $\left(\mathrm{P}^{\mathrm{P}} \mathrm{CO}_{2}\right)$ 4-32

Effect of Gasification Medium 4-35

Carbon Mass Balance During Char Gasification in $\mathrm{CO}_{2}$ 4-35

Kinetic Parameters 4-39

Comparison Between Combustion and Gasification Reaction Rates

of Chars 4-47

Surface Area-Reactivity Relationships $\quad$ 4-47

Morphology of Coals and Chars 4-49

5 APPLICATION 5-1

DTFS Performance Predictions $\quad 5-1$

Char Combustion 5-1

Char Gasification $\quad 5-4$

Coal Gasification $\quad 5-9$ 
APPENDIX A TEST FACILITIES

APPENDIX B REACTION KINETIC PARAMETER DETERMINATIONS

APPENDIX C SUMMARY OF DROP TUBE FURNACE SYSTEM (DTFS) TEST DATA

$c-1$

APPENDIX D CHAR COMBUSTION/GASIFICATION MODEL

$D-1$ 
$\vartheta$

0 
Figure $\quad \underline{\text { Page }}$

1-1 Combustion Engineering Atmospheric Gasification Process Development Unit (PDU)

$1-2$

2-1 Typical TGS-2 System Micro-Proximate Analysis of Coal 2-3

2-2 Typical TGS-2 System Thermogram 2-4

4-1 Thermo-Gravimetric Burn-Off Curves in Air at $700^{\circ} \mathrm{C}$ for
Various $200 \times 400$ Mesh DTFS Chars

4-2 Thermo-Gravimetric Gasification Curves in Carbon Dioxide
at $950^{\circ} \mathrm{F}$ for Various Chars

4-3 Influence of BET Pore Surface Area $\left(S_{B E T}\right)$ on TGA

Combustion and Gasification Reactivity Parameters $\left(R_{T}\right)$

for $200 \times 400$ Mesh Chars

4-4 Axial Gas Temperature Profiles in the Drop Tube Furnace System Reaction Zone

4-5 Effect of Gas Temperature on DTFS Combustion Efficiencies of $200 \times 400$ Mesh Coals

4-6 Effect of Gas Temperature on DTFS Combustion Efficiencies of Various $200 \times 400$ Mesh Chars

4-7 Effect of Fuel Type on DTFS Combustion Efficiencies of Various $200 \times 400$ Mesh Chars at Three Gas Temperatures

4-8 Effect of Oxygen Partial Pressure on DTFS Combustion Efficiency of $200 \times 400$ Mesh PSC Char at $2650^{\circ} \mathrm{F}$ Gas Temperature

4-9 Arrhenius Plots for $200 \times 400$ Mesh Char Combustion in the DTFS

4-10 Variation of Combustion Surface Reaction Rate Coefficient with Temperature for Various Chars in the DTFS

4-11 Variation of In $\mathrm{K}^{\prime}$ s with $\mathrm{ln}\left[\mathrm{0}_{2}\right]$ for $200 \times 400$ Mesh PSC Char Combustion in the DTFS at $2650^{\circ} \mathrm{F}$ Gas Temperature

4-12a Effect of Gas Temperature on DTFS Gasification Efficiencies of TXL and JRC $200 \times 400$ Mesh Chars

4-12b Effect of Gas Temperature on DTFS Gasification Efficiencies of ILC and PSC $200 \times 400$ Mesh Chars 
4-13 Effect of Fue 1 Type on DTFS Gasification Efficiencies of Various $200 \times 400$ Mesh Chars at Three Gas Temperatures

4-14 Effect of Particle Size on DTFS Gasification Efficiencies of Various Chars at $2650^{\circ} \mathrm{F}$ Gas Temperature

4-15 Effect of Carbon Dioxide Partial Pressure on DTFS Gasification Efficiency of $200 \times 400$ Mesh PSC Char at $2650^{\circ} \mathrm{F}$ Gas Temperature

4-16 Effect of Gas Temperature on DTFS Gasification Efficiency of $200 \times 400$ Mesh JRC Char in Steam

4-36

4-17 Effect of Temperature and Reaction Medium on DTFS Gasification Efficiency of $200 \times 400$ Mesh JRC Char

4-36

4-18 Comparison Between Ash Tracer and Co Composition Methods for Calculating Gasification Efficiencies of Various Chars

4-38

4-19a Arrhenius Plots for Gasification of $200 \times 400$ Mesh TXL and JRC Chars in the DTFS

4-41

4-19b Arrhenius Plots for Gasification of $200 \times 400$ Mesh ILC and PSC Chars in the DTFS

$4-42$

4-20 Variation of Gasification Surface Reaction Rate Coefficient with Temperature for Various Chars in the DTFS

4- 44

4-21 Variation of $1 n \mathrm{~K}^{\prime}$ s with $\mathrm{ln}\left[\mathrm{CO}_{2}\right]$ for $200 \times 400$ Mesh PSC Char Gasification in the DTFS at $2650^{\circ} \mathrm{F}$ Gas Temperature

4-22 Relationship of BET Pore Surface Area $\left(S_{B E T}\right)$ with DTFS Combustion and Gasification Surface Reaction Rate Coefficients $\left(\mathrm{K}_{\mathrm{S}}\right)$ for $200 \times 400$ Mesh Chars

4-23 Scanning Electron Micrographs of $200 \times 400$ Mesh Coals 4-50

4-24 Scanning Electron Micrographs of TXL Chars 4-51

4-25 Scanning Electron Micrographs of JRC Chars 4-52

4-26 Scanning Electron Micrographs of ILC Chars 4-53

4-27 Scanning Electron Micrographs of PSC Chars 4-54

5-1 Effect of Gas Temperature on Predicted DTFS Combustion Efficiencies of Various $200 \times 400$ Mesh Chars

5-2 Effect of Percent Excess Air on Predicted Combustion Efficiency of $200 \times 400$ Mesh PSC Char at an Isothermal Temperature of $3000^{\circ} \mathrm{F}$ 
5-3a Effect of Gas Temperature on Predicted DTFS Gasification Efficiencies of TXL and JRC $200 \times 400$ Mesh Chars

5-3b Effect of Gas Temperature on Predicted DTFS Gasification Efficiencies of ILC and PSC $200 \times 400$ Mesh Chars

5-4 Effect of Carbon Dioxide Partial Pressure on Predicted DTFS Gasification Efficiency of $200 \times 400$ Mesh PSC Char at $2650^{\circ} \mathrm{F}$ Gas Temperature

5-5 Effect of Particle Size on Predicted DTFS Gasification Efficiencies of Various Chars at $2650^{\circ} \mathrm{F}$ Gas Temperature

5-6 Effect of Fuel Type on Predicted DTFS Gasification Efficiencies of $70 \%-200$ Mesh Coals

5-7 Effect of Temperature, Particle Size, and Carbon Dioxide Partial Pressure on Predicted DTFS Gasification Efficiencies of PSC Coal

A-1 Schematic of Flammability Apparatus

$A-2$

A-2 Schematic of the Combustion Engineering Drop Tube Furnace System. 
$\ominus$

•

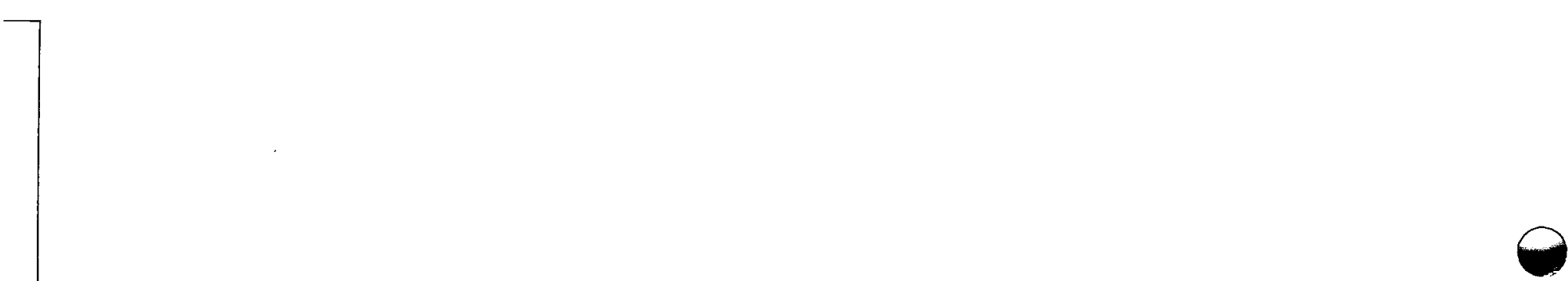


TABLES

$\underline{T a b l e}$

1-1 Sources and ASTM Ranks of Coals 1-6

2-1 Test Matrix for Drop Tube Furnace System (DTFS) Evaluation of Coals and Chars

4-1 Analyses of Parent Coals 4-2

4-2 Proximate and Ultimate Analyses of Size Graded Coals and Chars

4-4

4-3 Particle Size Distributions for Size Graded Coals and Chars 4-5

4-4 Surface Area $\left(S_{X}\right)$ and Reactivity Parameter $\left(R_{T}\right)$ Results for Coal Chars

$4-6$

4-5 Swelling Factors of Coals During DTFS Pyrolys is in Nitrogen at $2650^{\circ} \mathrm{F}$ Gas Temperature

$4-14$

4-6 Particle Size Changes During Pyrolysis in Nitrogen at $2650^{\circ} \mathrm{F}$ for Pittsburgh Seam Coal and Char

$4-15$

4-7 Comparison Between ASTM Volatile Matters of Coals and Their DTFS Pyrolysis Weight Losses in Nitrogen at $2650^{\circ} \mathrm{F}$ Gas

Temperature

$4-16$

4-8 Particle Size changes During DTFS Char Combustion at $2650^{\circ} \mathrm{F}$ Gas Temperature

$4-21$

4-9 Kinetic Data from Combustion of $200 \times 400$ Mesh Chars in 0.03 0xygen Atmosphere and $1800-2650^{\circ} \mathrm{F}$ Temperature Range

4-23

4-10 Data for Evaluating Combustion Reaction Order of $200 \times 400$

Mesh PSC Char

$4-28$

4-11 Carbon Mass Balance for Gasification of Chars in 0.3 Carbon Dioxide Atmosphere at Various Gas Temperatures

4-12 Partcle Size Changes During DTFS Char Gasification at $2650^{\circ} \mathrm{F}$ Gas Temperature

4-13 Kinetic Data from Gasification of $200 \times 400$ Mesh Chars in 0.3 Carbon Dioxide Atmosphere and $2000-2650^{\circ} \mathrm{F}$ Temperature Range $4-40$

4-14 Data for Evaluating Gasification Reaction Order of $200 \times 400$ Mesh PSC Char

4-15 Ratios of Combustion to Gasification Surface Reaction Rate Coefficients of $200 \times 400$ Mesh Chars 
SUMMARY, CONCLUSIONS, AND RECOMMENDATIONS

PROJECT BACKGROUND AND OBJECTIVE

Combustion Engineering, Inc., (C-E) has been developing coal gasification technology geared towards producing a clean low-Btu fuel gas suitable for electric power generation. Pilot scale testing has been carried out on a five-ton per hour Process Development Unit (PDU) using a Pittsburgh seam coal. Three other commercially significant coals of different rank were selected for potential testing in the PDU, including a Texas lignite, a Wyoming subbituminous coal, and an Illinois No. 6 coal. However, the PDU program was terminated before such additional coals could be tested.

During the course of process development, substantial differences between actual and predicted gasification rates with the Pittsburgh seam coal were found. Hence, the need arose to characterize the fundamental behavior of coals and chars undergoing combustion and gasification reactions under commercial conditions.

The ultimate objective of this study was to develop detailed fundamental information on the combustion and gasification characteristics of the four designated commercially significant coals and their chars. This information could subsequently be used by the PDU gasification project to assess the effect of operating parameters and fuel properties on performance.

\section{TEST FACILITIES AND PROCEDURES}

Standard ASTM (American Society for Testing Materials) procedures along with special bench scale tests and the Drop Tube Furnace System (DT.FS) were employed in this program. Standard ASTM tests consisted of proximate, ultimate, and screen analyses, higher heating value, ash composition, ash fusibility temperatures, and Hardgrove Grindability Index. Special bench scale tests consisted of Micro-Proximate, Micro-Ultimate $(H, C, N)$, and Coulter Counter Analyses, Flammability Index, Pore Surface Area, Thermo-Gravimetric Reactivity, and Scanning Electron Microscopy (SEM). 
The Perkin-Elmer TGS-2 System was used to determine both the micro-proximate analyses of coals and chars and the thermo-gravimetric combustion and gasification reactivities of chars. The Perkin-Elmer 240 Elemental Analyzer was used to determine micro-ultimate analyses of coals and chars.

The Quantachrome Corporation Surface Area Analyzer was used to measure both the $\mathrm{N}_{2}$ and $\mathrm{CO}_{2}$ pore surface areas of chars in conjunction with the Brunauer, Emmett, and Teller (BET) and Dubinin-Kaganer gas adsorption principles $(\underline{1}, \underline{2})$. The Flammability Index Apparatus was used to determine relative ignition temperatures of coals in an oxygen atmosphere.

The electrically-heated Drop Tube Furnace System (DTFS) was used to determine the pyrolysis, combustion and gasification characteristics of coals and/or chars in the $1800-2650^{\circ} \mathrm{F}$ gas temperature range. The reaction histories were monitored by solid/gas sampling at various points along the DTFS reaction zone with a two-inch inner diameter and a sixteen-inch length.

\section{TEST PROGRAM}

Chars for this study were prepared from four parent coals in the DTFS in the presence of helium at $2650^{\circ} \mathrm{F}$. Parent coals consisted of a Pittsburgh No. 8 Seam (PSC) hvAb, an I1linois No. 6 Seam (ILC) hvCb, a Wyoming wyodak Seam (JRC) Sub C, and a Texas Wilcox Seam ( $T X L$ ) Lig $A$. Residence time under the operating conditions was about 0.5 second. Physical and chemical properties of size-graded chars were determined along with those of parent coals in the standard ASTM and special bench scale tests previously identified.

Selected chars were subjected to thermo-gravimetric combustion in air at $700^{\circ} \mathrm{C}$ $\left(1292^{\circ} \mathrm{F}\right)$ and gasification in carbon dioxide at $950^{\circ} \mathrm{C}\left(1742^{\circ} \mathrm{F}\right)$. The effect of particle size on char gasification was also investigated.

Size graded coals were pyrolyzed in the DTFS in the presence of nitrogen at $2650^{\circ} \mathrm{F}$ to assess their swelling characteristics and pyrolysis efficiencies. Pyrolysis efficiencies were compared with corresponding ASTM-determined volatile matter yields.

The DTFS was used extensively to examine the effects of various experimental parameters (temperature, residence time, reactant gas partial pressure, and 
particle size) on the combustion and gasification characteristics of size-graded chars. The effects were quantified in the form of kinetic rate expressions for combustion and gasification.

A plug-flow combustion/gasification model was subsequently used to predict DTFS combustion and gasification performance of the coal chars under specific conditions.

\section{RESULTS}

Combustion and gasification studies in both the DTFS and TGA apparatus showed that the lower rank coal chars were more reactive than the higher rank coal chars and that the combustion reaction was much faster than the gasification reaction. Fuel properties, temperature, and reactant gas partial pressure had significant effects on both combustion and gasification. Combustion and gasification char reactivities were closely related to char pore structure.

Char combustion was sensitive to the nature of the fuel, temperature, and oxygen partial pressure. Relative char combustion reactivities were: TXL $>$ ILC $>$ JRC $>$ PSC. At $2650^{\circ} \mathrm{F}$ gas temperature, $0.03 \mathrm{~atm} .0_{2}$, and $0.6 \mathrm{sec}$. residence time corresponding combustion efficiencies were $97 \%, 95 \%, 88 \%$, and $72 \%$. Activation energies for combustion ranged from $17 \mathrm{Kcal} / \mathrm{mole}$ (ILC char) to $20 \mathrm{Kcal} / \mathrm{mole}$ (PSC char). The PSC char was studied in more detail than the other three chars. Its combustion efficiency increased with increasing temperature and oxygen partial pressure as follows: (1) from $30 \%$ to $72 \%$ as the temperature increased from $1800^{\circ} \mathrm{F}$ to $2650^{\circ} \mathrm{F}$ at $0.030_{2}$ atm. and $0.6 \mathrm{sec}$. residence time; and (2) from $30 \%$ to $97 \%$ as the $0_{2}$ partial pressure increased from 0.01 atm. to $0.05 \mathrm{~atm}$. at $2650^{\circ} \mathrm{F}$ gas temperature and $0.6 \mathrm{sec}$. residence time. The reaction rate of this char exhibited near first order (0.92) dependence on oxygen concentration.

Char gasification was even more sensitive to fuel and temperature variations than combustion. Carbon dioxide partial pressure also had a pronounced effect on gasification. Relative char gasification reactivities were: TXL > JRC > ILC > PSC. At $2650^{\circ} \mathrm{F}$ gas temperature, $0.3 \mathrm{~atm} . \mathrm{CO}_{2}$, and $0.6 \mathrm{sec}$. residence time corresponding gasification efficiencies were $76 \%, 66 \%, 19 \%$, and $6 \%$. The lower rank coal (TXL and JRC) chars had much higher reactivities than higher rank coal (ILC and $P S C$ ) chars. Activation energies for gasification ranged from $39.5 \mathrm{Kcal} / \mathrm{mole}$ (TXL char) to $56 \mathrm{Kcal} / \mathrm{mole}$ (ILC char) indicating the pronounced effect of temperature. The PSC char was studied in more detail than the other three chars. Its 
gasification efficiency increased with increasing temperature and $\mathrm{CO}_{2}$ partial pressure and decreasing particle size as follows: (1) from less than $1 \%$ to $6 \%$ as the temperature increased from $2200^{\circ} \mathrm{F}$ to $2650^{\circ} \mathrm{F}$ at $0.3 \mathrm{CO}_{2}$ atm. and $0.6 \mathrm{sec}$. residence time, (2) from $6 \%$ to $16 \%$ as the particle size distribution decreased from $200 \times 400$ mesh to -400 mesh at $2650^{\circ} \mathrm{F}$ gas temperature, $0.3 \mathrm{CO}_{2}$ atm., and 0.6 sec. residence time; and (3) from $3 \%$ to $9 \%$ as the $\mathrm{CO}_{2}$ partial pressure increased from $0.15 \mathrm{~atm}$. to $0.6 \mathrm{~atm}$. at $2650^{\circ} \mathrm{F}$ gas temperature and $0.6 \mathrm{sec}$. residence time. The reaction rate of this char exhibited near first order $(0.91)$ dependence on $\mathrm{CO}_{2}$ concentration.

Carbon mass balance determinations were conducted during DTFS gasification of PSC, ILC, JRC, and TXL chars in $0.3 \mathrm{~atm}$. of carbon dioxide at various temperatures. Results indicate carbon closures in the $85-103 \%$ range. Nine out of a total of sixteen data points were within $90-100 \%$ range.

Pore structure plays a major role in determining fuel gasification and combustion reactivity. Scanning Electron Microscopy (SEM) of DTFS chars indicated very high porosity and a large open pore structure for the TXL and JRC chars accounting for their high reactivities. It also confirmed the agglomerating nature of the PSC coal which resulted in a spherical-shaped char with lower porosity and a relatively closed pore structure, accounting for its low reactivity. Gasification reactivities also closely followed char BET surface areas indicating the important effect of pore structure. BET surface areas of the TXL, JRC, ILC, and PSC DTFS chars were $213,97,54$, and $13 \mathrm{~m}^{2} / \mathrm{g}$ on a dry-ash-free basis, respectively.

Studies on particle size changes were also conducted during pyrolysis, combustion, and gasification experiments to determine reaction mechanisms and aid in modelling efforts. These studies indicated that: (1) the PSC coal swelled (increase in diameter of 40\%) while the other coals were non-swelling; (2) DTFS (high heating rate) volatile losses were $10 \%$ and $20 \%$ greater than ASTM volatile matter determinations for the ILC and PSC coals respectively; and (3) combustion and gasification could be assumed to proceed by the "shrinking core" mechanism.

Reaction kinetics and mechanisms determined from the DTFS studies were incorporated into a computer simulation of the DTFS. Results of this simulation agreed well with experimental results and quantified the importance of such factors as temperature and reactant partial pressure. 


\section{CONCLUSIONS}

The major conclusions that can be drawn from the results of this study are the following:

- Chars from Texas Lignite, Wyoming Sub C, and Illinois No. 6 hvCb coals are comparable in combustion reactivity and are significantly more reactive than the char from Pittsburgh No. 8 hvAb coal. Nevertheless, computer simulations based on DTFS kinetic information indicate that Pittsburgh hvab coal char can be successfully burned provided that operational conditions (temperature, oxidant to fuel ratio, particle size, and residence time) are favorable.

- Char gasification reactivites follow this trend: Texas Lignite > Wyoming Sub $C>$ Illinois No. 6 hvCb $>$ Pittsburgh No. 8 hvAb. The difference between the least reactive char and most reactive char is greater than a factor of 10 .

- Pore structure plays a major role in determining fuel reactivity for both gasification and combustion. Char gasification reactivities follow the same trend as BET surface areas. In addition, Scanning Electron Micrographs indicate that the Texas Lignite and Wyoming Sub $C$ chars had large, open pores while the Pittsburgh No. 8 hvAb char generally exhibited a closed pore structure. The Illinois No. 6 hvCb char exhibited intermediate porosity.

- Char gasification rates are highly dependent on temperature and reactant gas concentration. Activation energies are in the $39.5-56 \mathrm{Kcal} / \mathrm{mole}$ range. The reaction rate exhibited near first order (0.9) dependency with respect to carbon doxide concentration. Char gasification efficiencies also increase with increasing residence time and decreasing particle size.

- While the Pittsburgh No. 84 hvab coal swelled by $40 \%$ during pyrolysis at the high heating rates $\left(10^{4}{ }^{\circ} \mathrm{C} / \mathrm{sec}\right.$.) encountered in the DTFS, the other three coals did not. Pyrolysis weight losses in the DTFS were $20 \%$ and $10 \%$ greater than ASTM volatile matter yields for the Pittsburgh No. 8 hvAb and Illinois No. 6 hvCb coals, respectively. However, the Wyoming Sub $C$ coal and Texas lignite did not show significant differences between DTFS pyrolysis weight losses and ASTM volatile matter yields.

- Computer simulations of the DTFS based on kinetic information determined in this study indicate that the Pittsburgh coal char is relatively unreactive during gasification such that practically attainable operational parameters (temperature, residence time, particle size, and reactant gas $\left(\mathrm{CO}_{2}\right)$ partial pressure) fail to substantially increase its gasification efficiency at atmospheric pressure in the DTFS. Either char recycle or char combustion or both must be employed to substantially increase the total carbon conversion for Pittsburgh char. Most of the conversion of the Pittsburgh No. 8 coal in the DTFS is due to pyrolysis rather than char gasification.

\section{RECOMMENDATIONS}

Practical application of results should take into consideration the high dependence of gasification efficiency on fuel properties, temperature, and carbon 
dioxide partial pressure, and the mild dependence of gasification efficiency on particle size. With respect to coal gasification at atmospheric pressure in a two stage reactor (combustor and reductor) the following is recommended:

- Screen candidate coals through computer simulations based on DTFS kinetics. This will eliminate the risks involved in using literature kinetic parameters which were generally derived under different conditions.

- Fire the combustor as intensely as possible with fuel ground as fine as commercially feasible (on the order of $80 \%$ through 200 mesh). This will serve to elevate temperatures which will enhance gasification. 
Section 1

INTRODUCTION

Coal gasification offers the potential for utilizing our nation's abundant coal reserves in a highly efficient environmentally acceptable manner. In most coal gasification processes a portion of the coal is burned to provide heat for the endothermic gasification reactions. The dependence of coal char combustion and gasification rates on gasifer operating parameters and fuel property effects plays a major role in determining gasifier performance.

PDU PROCESS

Combustion Engineering's (C-E) Coal Gasification Process Development Unit (PDU) was designed to gasify 5 tons of coal per hour in order to demonstrate the conversion of pulverized coal into a clean low-Btu fuel gas suitable for electric power generation.

The PDU has been described by Patterson and Darling ( $\underline{3}$ ), and Darling, Koucky, and Tanca (4). The PDU is a two-stage, air-blown, entrained-flow process operating at atmospheric pressure. Figure 1-1 depicts the process in block diagram. Coal (sized to 70\% -200 mesh), preheated air, and recycle char are blown tangentially into the first stage of the gasifier, the combustor, where they are burned substoichiometrically. This stage liberates the sensible energy in the gas required to drive the gasification reactions in the second stage. Hot gases (ca. $3000^{\circ} \mathrm{F}$ ) produced in the combustor rise through the necked-down entrance to the reductor zone and swirl upward. In the reductor zone fresh coal reacts with the hot gases. The resultant low-Btu gas contains mainly $\mathrm{N}_{2}, \mathrm{CO}, \mathrm{CO}_{2}$ and $\mathrm{H}_{2}$. The reductor outlet temperature is maintained above $1700^{\circ} \mathrm{F}$ to prevent the formation of tars and oils. The $3000^{\circ} \mathrm{F}$ combustor temperature is sufficient to melt the ash in the coal and char fired to the combustor. The molten ash drips through a slag tap hole located on the combustor floor. This slag flows by gravity to an ash quench tank where the slag is solidified, cooled and ground into a suitable size for disposal. 


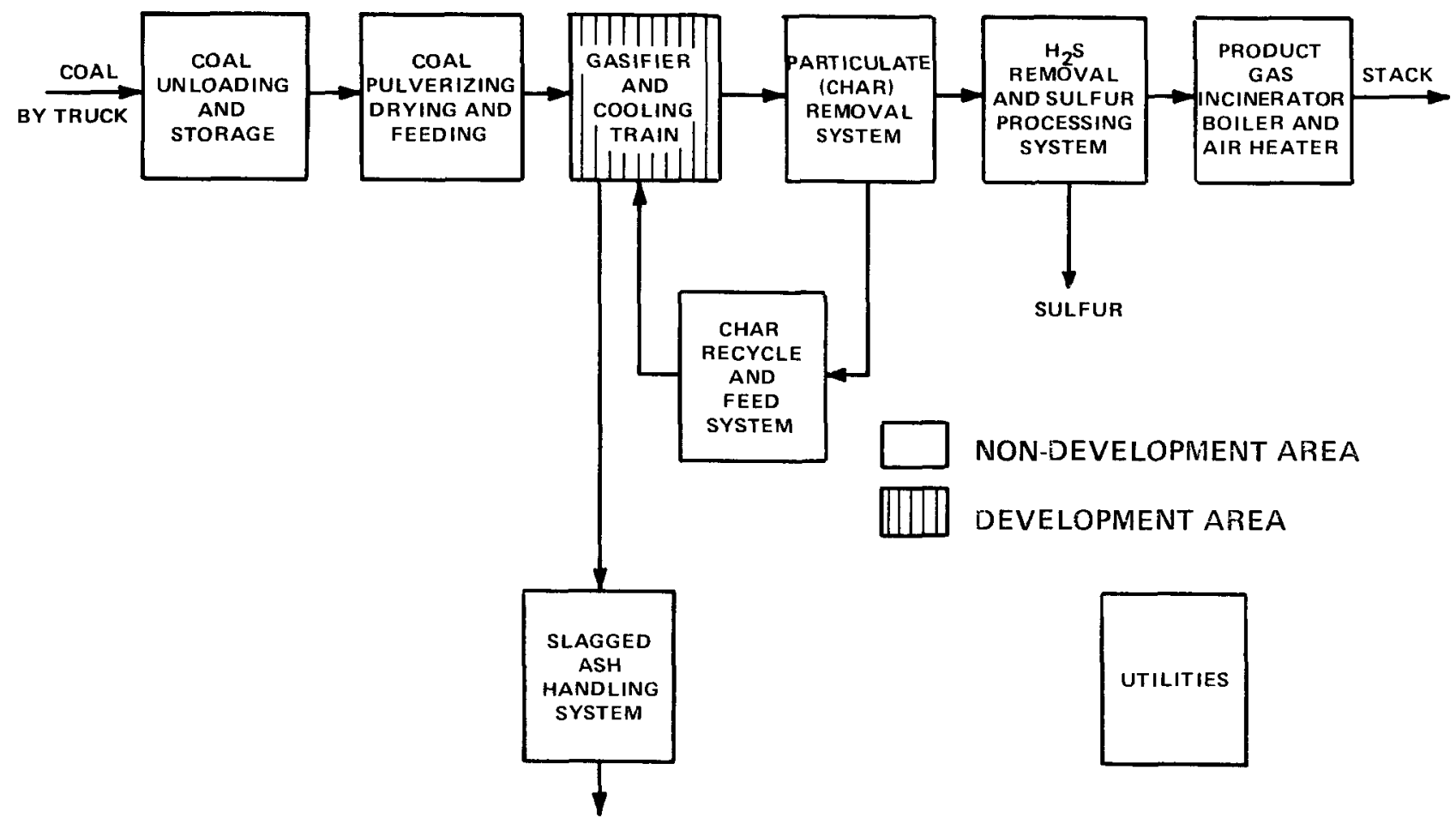

FIGURE 1-1 COMBUSTION ENGINEERING ATMOSPHERIC GASIFICATION PROCESS DEVELOPMENT UNIT (PDU) 
Particulates in the form of carbon and ash leave the gasifier, entrained in the low-Btu gas stream. A particulate removal/char recycle system is utilized to remove particulate (char) from the gas stream. A wet scrubber system and baghouse are employed for final particulate removal. The char is stored and recycled back to the combustor via pneumatic transport with preheated air. The resultant dust-free gas leaving the particulate removal system is fed to a Stretford sulfur removal system. The sulfur, mainly in the form of $\mathrm{H}_{2} \mathrm{~S}$, is scrubbed from the gas stream, producing a clean-burning fuel. The sulfur collected from the gas stream is transformed into elemental sulfur. The product gas leaving the sulfur removal system is a low-Btu fuel gas suitable for use in utility boilers, gas turbines, or as a process fuel.

\section{SUMMARY OF PREVIOUS WORK}

\section{Char Gasification}

Limited work has been done on the kinetics of char gasification in entrained-flow systems similar to the DTFS used in this program. The work summarized below is relevant to this work. Wen and Chuang (ㅁ) used in their entrained-bed coal gasification modelling studies kinetic parameters derived by Dobner ( $\underline{6}$ ) from Gray and Kimber's work at BCURA (British Coal Utilization Research Association) (7) (performed in the $3680-4580^{\circ} \mathrm{F}$ temperature range). The kinetic paramters proposed by Dobner for char gasification in carbon dioxide and steam are $42 \mathrm{Kcal} / \mathrm{mole}$ for activation energy (E) and $247 \mathrm{~g} \mathrm{~cm}^{-2} \mathrm{sec}^{-1} \mathrm{~atm}^{-1}$ for frequency factor (A).

Most recently, Knight and Sergeant ( 8 ) conducted kinetic studies on four Australian coal chars in carbon dioxide in a thermo-gravimetric analysis apparatus. They found that for their low reactivity Lithgow coal char, reactivity increased with increasing $\mathrm{CO}_{2}$ concentration and decreasing particle size. Their apparent reaction order with respect to $\mathrm{CO}_{2}$ concentration was 0.7 . The activation energies for the four chars studied were in the $52-56 \mathrm{Kcal} / \mathrm{mole}$ (performed in the $1472-1900^{\circ} \mathrm{F}$ range).

\section{Char Combustion}

There also is a paucity of data on the kinetics of coal char combustion in entrained-flow reactors. Field and co-workers (9) carried out work in this area at BCURA. They derived, by the method of least squares fit, kinetic parameters from data found in the literature. They came up with values of $35.7 \mathrm{kcal} / \mathrm{mole}$ for activation energy and $8710 \mathrm{~g} \mathrm{~cm}^{-2} \mathrm{sec}^{-1} \mathrm{~atm}^{-1}$ for frequency factor. 
Field (10, 11) also gives a step-by-step method of calculating kinetic parameters ( $E$ and $A$ ) of coal char combustion. This method was followed in this program and is illustrated in section 3.

\section{PROJECT OBJECTIVE AND TECHNICAL APPROACH}

The PDU, designed to develop coal gasification technology, has been supported by the US Department of Energy, Combustion Engineering, Inc., and Electric Power Research Institute (EPRI). EPRI support was under RP244-1. A Pittsburgh Seam Coal has been extensively investigated in the PDU, and three other commercially significant coals varying in rank from high volatile bituminous to lignite (see below) were prime candidates for study in this unit.

In the course of PDU studies it was decided to develop, under EPRI RP1654-6, fundamental data on combustion and gasification of four coals and chars produced therefrom. This study was carried out in bench scale equipment where various operational parameters (particle size, partial pressure of the reactant gas, temperature, residence time, and nature of coal) could be varied with greater flexibility than was practically possible with the 5 tons/hr PDU. The objective of this project was to support coal gasification development by determining detailed and quantitative information on the combustion and gasification characteristics of four coals and their chars.

Bench scale tests were conducted to characterize parent coals' chemical and physical properties, and ignition behavior. Physical, chemical, and thermogravimetric reactivity characteristics of the chars derived from parent coals were also determined. Tests performed in C-E's suspension-fired Drop Tube Furnace System (DTFS) were designed to quantify combustion and gasification characteristics of coal chars from a reaction kinetic standpoint.

Data obtained from the DTFS were computer processed to calculate char combustion and gasification kinetic parameters (activation energy and frequency factor). These kinetic parameters were subsequently used to predict combustion and gasification performance of the subject coal chars under specific conditions.

\section{SELECTION OF PARENT COALS}

Coals were selected for gasification technology development on the bas is of the following criteria: (1) they were from coal mines of commercial significance; 
(2) they covered a wide range of rank; and (3) they had certain specific properties which would be important in a gasification process (moisture contents, sulfur contents, ash fusion temperatures, caking properties, etc.).

The four coals selected for this purpose are identified in Table 1-1. They range from high volatile bituminous $A$ coal (hvAb) to lignite $A$ (lig A) as follows: (1) A high volatile bituminous coal (hvAb) from Pittsburgh No. 8 Seam, Delton Mine, Harrison County in West Virginia; (2) A high volatile bituminous $C$ coal (hvCb) from Illinois No. 6 Seam, Crown II Mine, Macoup in County in Illinois; (3) A subbituminous $C$ coal (Sub $C$ ) from Wyodak Seam, Jacobs Ranch Range Mine, Campbe11 County in Wyoming; and (4) A lignite A (Lig A) from Wilcox Seam, Monticello Mine, Titus County in Texas.

To facilitate their identification, these coals have been assigned the following codes: PSC for the Pittsburgh No. 8 coal, ILC for the Illinois No. 6 coal, JRC for the Jacobs Ranch Range coal, and IXL for the Texas coal. Their respective chars produced in the DTFS are identified as PSCC, ILCC, JRCC, and TXLC. 
Table 1-1

SOURCES AND ASTM RANKS OF COALS

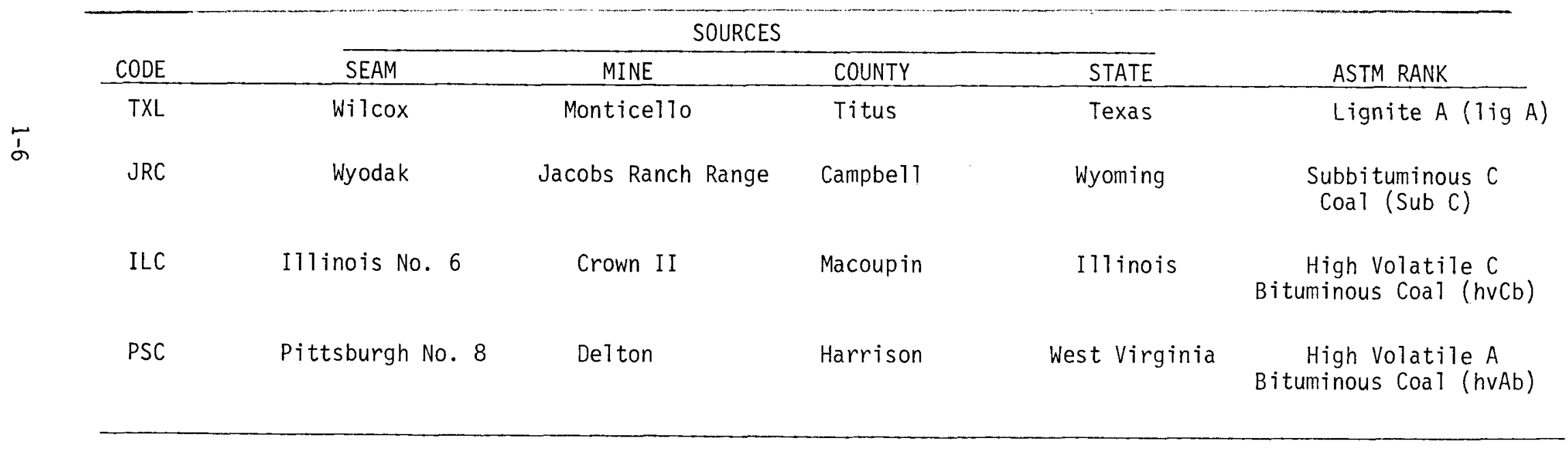




\section{Section 2}

EXPERIMENTAL PROCEDURES

CHARACTERIZATION OF COAL, ASH, AND CHAR SAMPLES

\section{ASTM Techniques}

ASTM (American Society for Testing Materials) techniques were used to determine the proximate, ultimate, screen analyses, Higher Heating Values, and Hardgrove grindability indices of parent coals, and coal ash fusibility temperatures and compositions. The proximate, ultimate, and screen analyses of coal chars were also determined by ASTM techniques.

\section{Special Techniques}

Special in-house techniques were used to determine the following: (1) the Flammability Indices of the parent coals; (2) the micro-proximate analyses, specific pore surface areas, and Thermo-Gravimetric Analyses of size graded chars. These techniques are briefly described in the following sub-sections. The morphologies and particle size distributions of the size graded chars were also determined using Scanning Electron Microscopy (SEM) and Coulter Counter techniques, respectively.

Flammability Index. The Flammability Index is a relative ignition temperature obtained by running tests under a given set of conditions in a specific apparatus. Briefly, testing involves firing 0.2 gram of fuel (typically 100 percent through 200 mesh) in an oxygen atmosphere through a preheated furnace. The temperature of the furnace is increased incrementally until a point is reached where the fuel will ignite. This temperature is called the Flammability Index. The value of the Flammability Index compared to other fuels indicates the flame ignition temperature/stability on a relative basis. This apparatus is described in Appendix A.

Micro-Proximate Analyses. The Perkin-Elmer TGS-2 System was used to determine the micro-proximate analyses of chars after it had been established that this apparatus yielded volatile matter results which were virtually indistinguishable 
from the corresponding ASTM proximate analyses. This method was used to save DTFS testing time since only milligrams, instead of one gram, of samples were required to determine their proximate analyses.

In this test procedure, a sample $(4-6 \mathrm{mg})$ is purged with nitrogen to remove oxygen traces. The moisture loss is obtained by heating in an inert atmosphere (nitrogen) to $105^{\circ} \mathrm{C}$ and holding for three minutes. Subsequently, the sample is heated at $100^{\circ} \mathrm{C} / \mathrm{min}$ to $950^{\circ} \mathrm{C}$ and held at this temperature for five minutes to obtain volatile matter. After this, the temperature is lowered to $750^{\circ} \mathrm{C}$ and a switching valve is used to introduce oxygen for the combustion of fixed carbon at this temperature. The residue represents the ash content. A sample plot of this analysis is shown in Figure 2-1. The TGS-2 equipment used for this analysis is described in Appendix A.

Specific Surface Areas. The principle of physical absorption of gases is used to determine specific surface areas of the solid fuels. Data obtained from nitrogen and carbon dioxide adsorptions at 77 and $298^{\circ} \mathrm{K}$, respectively, in the Quantasorb Surface Area Analyzer (manufactured by Quantachrome Corporation) are used in conjunction with the Brunauer, Emmett, and Teller (BET), and Dubinin-Kaganer Equations $(\underline{1}, \underline{2})$ to determine the BET $\left(\mathrm{N}_{2}\right)$ and $\mathrm{CO}_{2}$ specific surface areas of the subject fuels. The Surface Area Analyzer is described in Appendix A.

Thermo-Gravimetric Analyses. The Perkin-Elmer TGS-2 System is used to determine char combustion and gasification reactivities under isothermal conditions. A 4-6 mg sample is placed in the TGS-2 System and heated in the presence of nitrogen at $20^{\circ} \mathrm{C} / \mathrm{min}$ to the reactivity temperature $\left(700^{\circ} \mathrm{C}\right.$ for combustion and $950^{\circ} \mathrm{C}$ for gasification). After stabilization at this temperature, the reaction medium (air for combustion and carbon dioxide for gasification) is introduced. The percent weight of the unburned or ungasified char and rate of weight loss are recorded on a strip chart as a function of time. These thermo-grams (Figure 2-2) are subsequently used to determine the char combustion or gasification efficiency history and reactivity parameter (which indicates the maximum rate of weight loss per unit weight of the original sample in the TGS-2 System).

COMBUSTION, GASIFICATION, AND PYROLYSIS OF SIZE GRADED COALS AND CHARS IN THE DROP TUBE FURNACE SYSTEM (DTFS)

\section{Test Matrix}

The DTFS testing of four coals (Pittsburgh No. 8 Seam hvAb, Illinois No. 6 Seam hvCb, Wyoming Jacobs Ranch Range Sub $C$, and Monticello lignite A) and chars pre- 


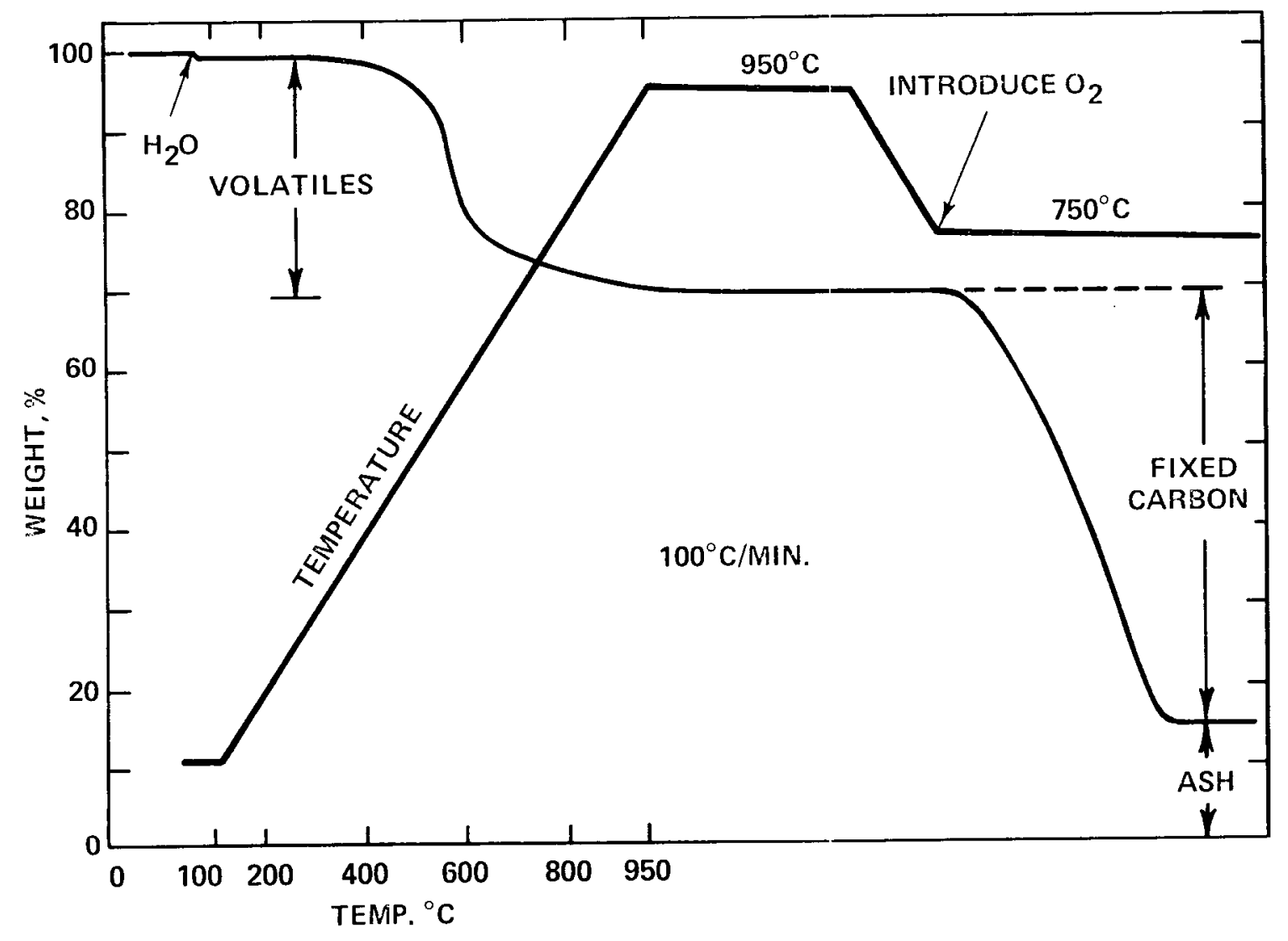

FIGURE 2-1 TYPICAL TGS-2 SYSTEM MICRO-PROXIMATE ANALYSIS OF COAL 


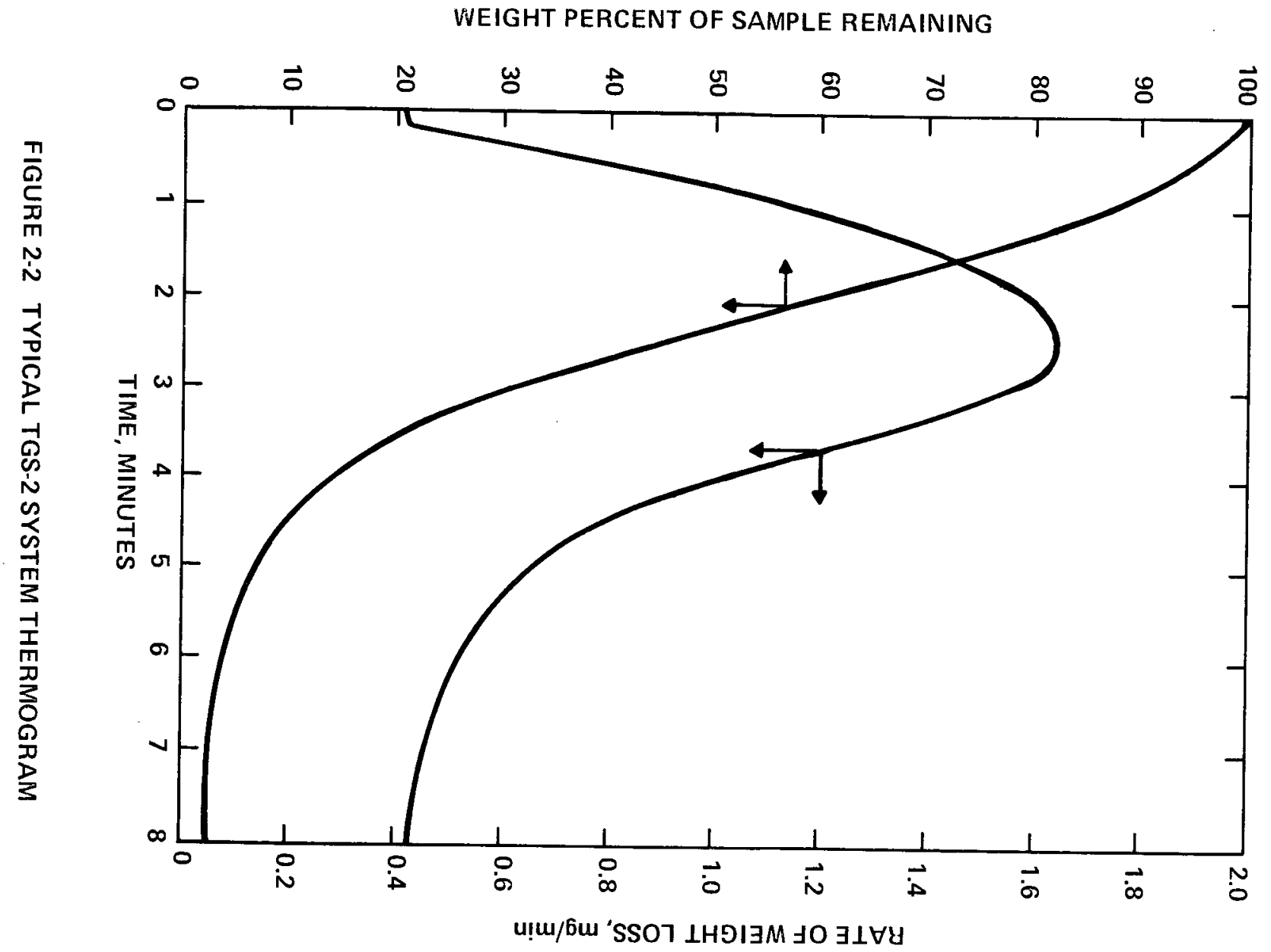


pared therefrom was designed to study the effects of various operational parameters on their combustion, gasification, and pyrolysis characteristics.

Combustion was studied as a function of oxygen concentration ( $1-5 \% \mathrm{O}_{2}$ in nitrogen balance) and gas temperature $\left(1800-2650^{\circ} \mathrm{F}\right)$. Gasification was studied as a function of carbon dioxide concentration (15-60\% in nitrogen balance), gas temperature $\left(2000-2650^{\circ} \mathrm{F}\right)$, particle size $(200 \times 400$ mesh and -400 mesh), and gasification medium (carbon dioxide and steam). Pyrolysis was studied in nitrogen and helium at gas temperatures of $2650^{\circ} \mathrm{F}$ and $1700^{\circ} \mathrm{F}$, respectively. Test conditions are summarized in the matrix shown in Table 2-1.

\section{Char Preparation}

Al1 the coal chars were prepared in the DTFS under strictly similar conditions so that differences in their physical and chemical characteristics were due solely to differences in the nature of their parent coals.

The preparation procedure involved the following. Pulverized coal was size graded to $200 \times 400$ mesh. The undersize particles $(-400)$ mesh were discarded. However, all the oversize $(+200$ mesh) particles were ground and size graded to $200 \times 400$ mesh; this fraction was added to the first fraction. This procedure enhanced the degree of representativeness of the coal in the $200 \times 400$ mesh fraction.

The $200 \times 400$ mesh coal was heat treated in the DTFS in the presence of helium under the following conditions: (1) coal feed rate $=1 \mathrm{~g} / \mathrm{min}$, (2) helium flow rate $=16 \ell / \mathrm{min} ;(3)$ reaction zone 1 ength $=16$ inches $(40.6 \mathrm{~cm})$; and $(4)$ temperature $=2650^{\circ} \mathrm{F}$. The particle heating rate under the prevailing conditions was of the order of $10^{4} \mathrm{o} / \mathrm{sec}$. Sufficient char was made to perform a given number of experiments. The resulting char was size graded to $200 \times 400$ mesh. The oversize particles (especially important for agglomerating coals) were ground and size graded to $200 \times 400$ mesh. This fraction was added to the first size cut. The undersize particles $(-400$ mesh) were saved, and this particular size fraction was subsequently used to study the effect of particle size on the char gasification efficiency. 
Table 2-1

TEST MATRIX FOR DROP TUBE FURNACE SYSTEM (DTFS) EVALUATION OF COALS ANO CHARS

\begin{tabular}{|c|c|c|c|c|c|}
\hline Fuel & Test No. & $\begin{array}{l}\text { Size Grades } \\
\text { (Mesh) }\end{array}$ & Study & $\begin{array}{l}\text { Reaction Medium } \\
\text { (Vol. x) }\end{array}$ & $\begin{array}{c}\text { Gas } \\
\text { Temp } \\
\left({ }^{\circ} \mathrm{F}\right)\end{array}$ \\
\hline \multirow[t]{5}{*}{$\begin{array}{l}\text { Pfttsburgh } \\
\text { No. } 8 \mathrm{COal} \text { (PSC) }\end{array}$} & $\begin{array}{l}\text { PSC-I-1 } \\
\text { PSC-I-5 }\end{array}$ & $\begin{array}{l}200 \times 400 \\
200 \times 400\end{array}$ & $\begin{array}{l}\text { Combustion } \\
\text { Combustion }\end{array}$ & $\begin{array}{lll}3 \% & 0_{2} / 97 \% & N_{2} \\
3 \% & 0_{2}^{2} / 97 \% & N_{2}^{2}\end{array}$ & $\begin{array}{l}1800 \\
2650\end{array}$ \\
\hline & PSC-IA-I & $200 \times 400$ & Pyrolysis & Hel fum ${ }^{1}$ & 1700 \\
\hline & PSC-1 I-5 & $200 \times 400$ & Pyrolysis & Nitrogen ${ }^{2}$ & 2650 \\
\hline & $\begin{array}{l}\text { PSCC-I-1 } \\
\text { PSCC-I-3 } \\
\text { PSCC-I -5 }\end{array}$ & $\begin{array}{l}200 \times 400 \\
200 \times 400 \\
200 \times 400\end{array}$ & $\begin{array}{l}\text { Combustion } \\
\text { Combustion } \\
\text { Combustion }\end{array}$ & 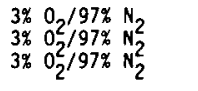 & $\begin{array}{l}1800 \\
2200 \\
2650\end{array}$ \\
\hline & $\begin{array}{l}\text { PSCC-II-5 } \\
\text { PSCC-III-5 }\end{array}$ & $\begin{array}{l}200 \times 400 \\
200 \times 400\end{array}$ & $\begin{array}{l}\text { Combustion } \\
\text { Combustion }\end{array}$ & 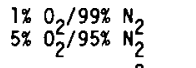 & $\begin{array}{l}2650 \\
2650\end{array}$ \\
\hline \multirow{6}{*}{$\begin{array}{l}\text { Pittsburgh Seam } \\
\text { Coal Chars } \\
\text { (PSCC) Prepared } \\
\text { in the DTFS }\end{array}$} & PSCC-IV-5 & $200 \times 400$ & Pyrolysis & Nitrogen ${ }^{2}$ & 2650 \\
\hline & $\begin{array}{l}P S C C-V A-5 \\
\text { PSCC-VB-5 } \\
\text { PSCC-VC-5 }\end{array}$ & $\begin{array}{l}200 \times 400 \\
200 \times 400 \\
200 \times 400\end{array}$ & $\begin{array}{l}\text { Gasification } \\
\text { Gasification } \\
\text { Gasification }\end{array}$ & $\begin{array}{lll}15 \% & \mathrm{CO}_{2} / 85 \% & \mathrm{~N}_{2} \\
30 \% & \mathrm{CO}_{2}^{2} / 70 \% & \mathrm{~N}_{2}^{2} \\
60 \% & \mathrm{CO}_{2}^{2} / 40 \% & \mathrm{~N}_{2}^{2}\end{array}$ & $\begin{array}{l}2650 \\
2650 \\
2650\end{array}$ \\
\hline & $\begin{array}{l}\text { PSCC-VI -3 } \\
\text { PSCC-VI-4 }\end{array}$ & $\begin{array}{l}200 \times 400 \\
200 \times 400\end{array}$ & $\begin{array}{l}\text { Gasification } \\
\text { Gasification }\end{array}$ & $\begin{array}{lll}30 \% & \mathrm{CO}_{2} / 70 \% & \mathrm{~N}_{2} \\
30 \% & \mathrm{CO}_{2}^{2} / 70 \% & \mathrm{~N}_{2}^{2}\end{array}$ & $\begin{array}{l}2200 \\
2450\end{array}$ \\
\hline & PSCC-VII-5 & $-400^{3}$ & Gasification & $30 \% \mathrm{CO}_{2} / 70 \% \mathrm{~N}_{2}$ & 2650 \\
\hline & PSCC-VIII-5 & $-400^{4}$ & Gasification & $30 \% \mathrm{CO}_{2} / 70 \% \mathrm{~N}_{2}$ & 2200 \\
\hline & $\begin{array}{l}\text { PSCC-IX-3 } \\
\text { PSCC-IX-5 }\end{array}$ & $\begin{array}{l}200 \times 400 \\
200 \times 400\end{array}$ & $\begin{array}{l}\text { Gasification } \\
\text { Gasification }\end{array}$ & $\begin{array}{lll}30 \% & \mathrm{H}_{2} \mathrm{O} / 70 \% & \mathrm{~N}_{2} \\
30 \% & \mathrm{H}_{2}^{2} \mathrm{O} / 70 \% & \mathrm{~N}_{2}^{2} \\
\end{array}$ & $\begin{array}{l}2200 \\
2650\end{array}$ \\
\hline \multirow{2}{*}{$\begin{array}{l}\text { Illinois No. } 6 \\
\text { Coal (ILC) }\end{array}$} & $\begin{array}{l}\text { ILC-I - I } \\
\text { ILC-I-5 }\end{array}$ & $\begin{array}{l}200 \times 400 \\
200 \times 400\end{array}$ & $\begin{array}{l}\text { Combustion } \\
\text { Combustion }\end{array}$ & $\begin{array}{lll}3 \% & 0_{2} / 97 \% & N_{2} \\
3 \% & 02 / 97 \% & N_{2}^{2}\end{array}$ & $\begin{array}{l}1800 \\
2650\end{array}$ \\
\hline & ILC-IA-I & $200 \times 400$ & Pyrolys is & Hel ium ${ }^{1}$ & 1700 \\
\hline & ILC-II-5 & $200 \times 400$ & Pyrolysis & Nitrogen ${ }^{2}$ & 2650 \\
\hline \multirow{3}{*}{$\begin{array}{l}\text { I1linois No. } 6 \\
\text { Coal Char } \\
\text { (ILCC) } \\
\text { Prepared in } \\
\text { the OTFS }\end{array}$} & $\begin{array}{l}\text { ILCC-I-I } \\
\text { ILCC-I-3 } \\
\text { ILCC-I-5 }\end{array}$ & $\begin{array}{l}200 \times 400 \\
200 \times 400 \\
200 \times 400\end{array}$ & $\begin{array}{l}\text { Combustion } \\
\text { Combustion } \\
\text { Combustion }\end{array}$ & $\begin{array}{lll}3 \% & 0_{2} / 97 \% & N_{2} \\
3 \% & 0_{2} / 97 \% & N_{2}^{2} \\
3 \% & 0_{2}^{2} / 97 \% & N_{2}^{2}\end{array}$ & $\begin{array}{l}1800 \\
2200 \\
2650\end{array}$ \\
\hline & $\begin{array}{l}\text { ILCC-III-3 } \\
\text { ILCC-II-4 } \\
\text { ILCC-II-5 }\end{array}$ & $\begin{array}{l}200 \times 400 \\
200 \times 400 \\
200 \times 400\end{array}$ & $\begin{array}{l}\text { Gasification } \\
\text { Gasification } \\
\text { Gasification }\end{array}$ & $\begin{array}{lll}30 \% & \mathrm{CO}_{2} / 70 \% & N_{2} \\
30 \% & \mathrm{CO}_{2}^{2} / 70 \% & N_{2}^{2} \\
30 \% & \mathrm{CO}_{2}^{2} / 70 \% & N_{2}^{2}\end{array}$ & $\begin{array}{l}2200 \\
2450 \\
2650\end{array}$ \\
\hline & ILCC-III-5 & $-400^{3}$ & Gasification & $30 \% \mathrm{CO}_{2} / 70 \% \mathrm{~N}_{2}$ & 2650 \\
\hline \multirow{4}{*}{$\begin{array}{l}\text { Jacobs Ranch } \\
\text { Range Coal } \\
\text { (JRC) }\end{array}$} & $\begin{array}{l}\text { JRC-I-1 } \\
\text { JRC-I -5 }\end{array}$ & $\begin{array}{l}200 \times 400 \\
200 \times 400\end{array}$ & $\begin{array}{l}\text { Combustion } \\
\text { Combustion }\end{array}$ & $\begin{array}{lll}3 \% & 0_{2} / 97 \% & N_{2} \\
3 \% & 0_{2}^{2} / 97 \% & N_{2}^{2}\end{array}$ & $\begin{array}{l}1800 \\
2650\end{array}$ \\
\hline & JRC-IA-1 & $200 \times 400$ & Pyrolysis & Hel ium ${ }^{1}$ & 1700 \\
\hline & $J R C-I I-5$ & $200 \times 400$ & Pyrolysis & Nitrogen ${ }^{2}$ & 2650 \\
\hline & $\begin{array}{l}\text { JRCC }-1-1 \\
\text { JRCC-I-3 } \\
\text { JRCC-I -5 }\end{array}$ & $\begin{array}{l}200 \times 400 \\
200 \times 400 \\
200 \times 400\end{array}$ & $\begin{array}{l}\text { Combustion } \\
\text { Combustion } \\
\text { Combustion }\end{array}$ & 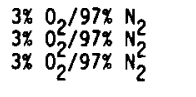 & $\begin{array}{l}1800 \\
2200 \\
2650\end{array}$ \\
\hline \multirow[t]{3}{*}{$\begin{array}{l}\text { Jacobs Ranch } \\
\text { Range Coal Chars } \\
\text { (JRCC) } \\
\text { Prepared in } \\
\text { the DTFS }\end{array}$} & $\begin{array}{l}\text { JRCC - II - } 2 \\
\text { JRCC-II - } \\
\text { JRCC-1I-4 } \\
\text { JRCC-II -5 }\end{array}$ & $\begin{array}{l}200 \times 400 \\
200 \times 400 \\
200 \times 400 \\
200 \times 400\end{array}$ & $\begin{array}{l}\text { Gasification } \\
\text { Gasification } \\
\text { Gasification } \\
\text { Gasification }\end{array}$ & $\begin{array}{lll}30 \% & \mathrm{CO}_{2} / 70 \% & \mathrm{~N}_{2} \\
30 \% & \mathrm{CO}_{2} / 70 \% & \mathrm{~N}_{2}^{2} \\
30 \% & \mathrm{CO}_{2} / 70 \% & N_{2}^{2} \\
30 \% & \mathrm{CO}_{2} / 70 \% & N_{2}^{2}\end{array}$ & $\begin{array}{l}2000 \\
2200 \\
2450 \\
2650\end{array}$ \\
\hline & $J R C-I I I-5$ & $-400^{3}$ & Gasification & $30 \% \mathrm{CO}_{2} / 97 \% \mathrm{~N}_{2}$ & 2650 \\
\hline & $\begin{array}{l}\text { JRCC-IV-3 } \\
\text { JRCC-IV-5 }\end{array}$ & $\begin{array}{l}200 \times 400 \\
200 \times 400\end{array}$ & $\begin{array}{l}\text { Gasification } \\
\text { Gasification }\end{array}$ & $\begin{array}{lll}30 \% & \mathrm{H}_{2} 0 / 70 \% & \mathrm{~N}_{2} \\
30 \% & \mathrm{H}_{2}^{2} 0 / 70 \% & \mathrm{~N}_{2}^{2} \\
\end{array}$ & $\begin{array}{l}2200 \\
2650\end{array}$ \\
\hline \multirow{2}{*}{$\begin{array}{l}\text { Texas Lignite } \\
(T \times L)\end{array}$} & $T X L-I-5$ & $200 \times 400$ & Combustion & $3 \% \mathrm{O}_{2} / 97 \% \quad \mathrm{~N}_{2}$ & 2650 \\
\hline & $T X L-11-5$ & $200 \times 400$ & Pyrolys is & Nitrogen 2 & 2650 \\
\hline \multirow{2}{*}{$\begin{array}{l}\text { Texas Lignite } \\
\text { Char (TXIC) } \\
\text { Prepared in } \\
\text { the DTfS }\end{array}$} & $T X L C-I-5$ & $200 \times 400$ & Combustion & $3 \% \mathrm{O}_{2} / 97 \% \mathrm{~N}_{2}$ & 2650 \\
\hline & $\begin{array}{l}T X L C-I 1-2 \\
T X L C-[1-3 \\
T X L C-[1]-5\end{array}$ & $\begin{array}{l}200 \times 400 \\
200 \times 400 \\
200 \times 400\end{array}$ & $\begin{array}{l}\text { Gasification } \\
\text { Gasification } \\
\text { Gasification }\end{array}$ & $\begin{array}{lll}30 \% \mathrm{CO}_{2} / 70 \% & \mathrm{~N}_{2} \\
30 \% \mathrm{CO}_{2} / 70 \% & \mathrm{~N}_{2} \\
30 \% \mathrm{CO}_{2} / 70 \% & \mathrm{~N}_{2}^{2}\end{array}$ & $\begin{array}{l}2000 \\
2200 \\
2650\end{array}$ \\
\hline
\end{tabular}

1. Samples obta ined for Advanced Fuel Research, East Hartford, CT.

2. To determine particle size change during coal pyrolysis.

3. Samples obtained by grinding a portion of $200 \times 400$ mesh chars.

4. Samples obtained by size grading the whole chars. 


\section{Sampling and Analysis}

The DTFS testing procedure entailed the following: (1) feed the fuel at a precisely known rate (in the $0.055-0.095 \mathrm{~g} / \mathrm{min}$ range) through a water-cooled injector into the test furnace reaction zone; (2) allow the fuel and its transport gas (ca. $150 \mathrm{~cm}^{3} / \mathrm{min}$ ) to rapidly mix with a pre-heated down-flowing secondary gas stream (12-16 l/min); (3) allow combustion, gasification, and/or pyrolysis to occur for a specified time (dictated by the transit distance); (4) quench the reactions by aspirating the products in a water-cooled sampling probe; (5) separate the solids from the gaseous products in a filter medium; and (6) determine on-line the $\mathrm{NO}_{\mathrm{X}}, \mathrm{O}_{2}, \mathrm{CO}_{2}$, and $\mathrm{CO}$ concentrations in the effluent gas stream. The particle heating and cooling rates in the DTFS are of the order of $10^{4} \mathrm{o} / \mathrm{sec}$. This is consistent with the findings of other research teams employing similar reactors $(12, \underline{13})$. The DTFS is described in Appendix A.

The data obtained from this study were processed by a computer program developed by Combustion Engineering, Inc. The data reduction techniques used are briefly described in Section 3. 
Section 3

DROP TUBE FURNACE SYSTEM DATA REDUCTION PROGRAM

The salient features of this program are (1) calculate the residence time of fuel particles as they flow down the DTFS reaction zone taking into account the reactant gas velocities as well as solid free fall velocities (14, 15); (2) calculate the combustion or pyrolysis efficiency by ash tracer method and gasification efficiency by $C O$ concentration method; and (3) calculate the reaction kinetic parameters (apparent activation energy and frequency factor) for char combustion and gasification. An existing Combustion Engineering ( $C-E$ ) data reduction computer program accomplishes all three tasks. The calculation methods used here are briefly described below.

\section{ASH TRACER METHOD}

This method is predicated on the assumption that the ash does not undergo appreciable changes during coal combustion or pyrolysis. As such, the combustion or pyrolysis efficiency $(\eta)$ can be calculated from the values of the ash contents in the feed sample and partially reacted char (collected at a given DTFS reaction zone position). This method is expressed in mathematical form (12, 16) as follows:

$$
\eta=100\left[1-\left(A_{0} /\left(100-A_{0}\right)\right)\left(\left(100-A^{\prime}\right) / A^{\prime}\right)\right]
$$

where $A_{0}$ and $A^{\prime}$ are the percent ash contents (dry basis) of the feed sample and partially reacted char, respectively.

\section{CARBON MONOXIDE CONCENTRATION METHOD}

The DTFS char gasification efficiencies were generally low compared with their combustion efficiencies. Therefore, it was decided to use the values of co concentrations in the effluent gas stream to determine all the char gasification efficiencies in this study. It was difficult to discern small differences in ash contents (ash tracer) but small concentrations of $\mathrm{CO}$ could be measured with high resolutions using Infrared Industries' CO Analyzer Model 703-021. 
This method is based on the following formula:

$$
\mathrm{C}+\mathrm{CO}_{2}=2 \mathrm{CO}
$$

which indicates that one mole of carbon in the char reacts with one mole of carbon dioxide to produce two moles of carbon monoxide. Based on Eq. (3-2) one can calculate the char gasification efficiency $(\eta)$ as follows:

$$
\eta=\left(V / V_{0}\right)[(1 / 2)(C 0)] /[\dot{m} \mathrm{c} / 12]
$$

where $V$ is the volumetric flow rate of the reactant gas (corrected to STP), $V_{0}$ is the STP volume occupied by one mole of an ideal gas, (CO) is the co concentration in volume percent, $\dot{m}$ is the mass feed rate of char, and $C$ is the percentage of carbon in the char.

CHAR COMBUSTION AND GASIFICATION KINETICS

The details of this calculation are given in Appendix B. Briefly, the overall reaction rate coefficient $(K)$ was determined as follows $(\underline{10}, \underline{11})$ :

$$
K=q / P_{g}
$$

where $q$ is the rate of removal of carbon per unit external surface $\left(\mathrm{g} \mathrm{cm}^{-2} \mathrm{sec}^{-1}\right)$ and $P_{g}$ is the reactant gas (oxygen or carbon dioxide) partial pressure in the free stream. It was determined from particle size distributions of the feed and partially reacted chars that both combustion and gasification reactions proceeded principally by a shrinking core mechanism. Hence, q was calculated on the basis of this assumption.

The diffusional reaction rate coefficient $\left(K_{\text {DIFF }}\right)$ is given by $(\underline{9}, \underline{10}, \underline{11})$

$$
K_{D I F F}=24 \emptyset D / \bar{X} R T
$$

where $D$ denotes the diffusion coefficient of the reactant $\left(0_{2}\right.$ or $\left.\mathrm{CO}_{2}\right)$ through the carrier $\left(\mathrm{N}_{2}\right)$ at temperature $T, T$ is the temperature of gas in the boundary layer around the particle $\left({ }^{\circ} \mathrm{K}\right), \bar{x}$ is the mean weight particle size $(\mathrm{cm}), R$ is the universal gas constant ( $82.06 \mathrm{~atm} . \mathrm{cm}^{3} \mathrm{~mole}^{-1} \mathrm{o}^{-1}$ ), and $\emptyset$ is a mechanism factor. 
The surface reaction rate coefficient $\left(K_{S}\right)$ was determined from the overall diffisional reaction rate coefficients Eqs. (3-4) and (3-5) as follows (10, 11)

$$
1 / K=1 / K_{D I F F}+1 / K_{S}
$$

A rearrangement of Eq. (3-6) yielded

$$
\left.K_{S}=K_{D I F F}{ }^{K /\left(K_{D I F F}\right.}{ }^{-K}\right)
$$

The Arrhenius Equation was used in conjunction with Eq. (3-7) to determine the apparent activation energy (E) and frequency factor (A) for char combustion or gasification in the temperature ranges studied $\left(1800-2650^{\circ} \mathrm{F}\right.$ for combustion and 2000-2650 $\mathrm{F}$ for gasification). That is,

$$
K_{S}=A \exp (-E / R T)
$$

where $R$ is the universal gas constant ( $1.986 \mathrm{cal} / \mathrm{deg} .{ }^{\circ} \mathrm{K}$ mole) and $T$ is reaction temperature in degrees Kelvin. The values of $E$ and $A$ were determined from the slopes and intercepts of the least squares fits of the $i n K_{S} v s .1 / T$ plots. 
Section 4

RESULTS

CHARACTERISTICS OF COAL, CHAR, AND ASH SAMPLES

\section{Coal Analyses}

Analyses and ranking of the as-received coal samples are presented in Table 4-1. The fuels ranged in rank from the Pittsburgh No. 8 high volatile A bituminous coal to the Texas lignite. Proximate analyses and Higher Heating Values are consistent with the rankings of these fuels. Table 4-1 depicts the criteria on which each coal was selected: (1) low moisture, high sulfur and Higher Heating Value, and caking properties for Pittsburgh No. 8 hvAb coal; (2) medium moisture and Higher Heating Value, high sulfur, and non-caking properties for Illinois No. 6 hvCb coal; (3) high moisture, low sulfur and Higher Heating Value for Wyoming Sub $C$; and (4) high moisture, ash, and ash fusion temperature, and low Higher Heating Value for Texas Lignite.

The Hardgrove grindability indices of these coals (49-64) indicate that pulverization of all the fuels fall within typically encountered commercial ranges and that no problems regarding the ease of pulverization should be encountered.

\section{Flammability Indices}

The Flammability Indices $\left(900-1010^{\circ} \mathrm{F}\right.$ ) are in the range typically encountered for fuels of these ranks (lignite to high volatile bituminous). In fact, some bituminous coals have exhibited Flammability Indices as high as $1200^{\circ} \mathrm{F}$. For reference, anthracites can have Flammability Indices of as high as $1700^{\circ} \mathrm{F}$. Results of the four fuels tested indicate that they ignite relatively easily and that turndown/ flame stability should not be a problem.

\section{Ash Analyses}

Ash fusibility temperatures and compositions are also presented in Table 4-1. Analyses of the Pittsburgh and Illinois coals ashes are typical of "Eastern" coal ashes (the $\mathrm{Fe}_{2} \mathrm{O}_{3}$ content being greater than the sum of the alkali and alkaline earth contents) while the Wyoming and Texas coal ashes are typical of "Western" ashes (the sum of the alkali and alkaline earth contents being higher than the 
Table 4-1

ANALYSES OF PARENT COALS

\begin{tabular}{|c|c|c|c|c|c|c|c|c|}
\hline \multirow[t]{2}{*}{ Analysis } & \multicolumn{2}{|c|}{$\begin{array}{c}\text { Texas } \\
\text { (Monticello) } \\
\text { Lignite A }\end{array}$} & \multicolumn{2}{|c|}{$\begin{array}{c}\text { Wyoming } \\
\text { (Jacobs Ranch Range) } \\
\text { Sub C }\end{array}$} & \multicolumn{2}{|c|}{$\begin{array}{c}\text { Illinois No. } 6 \\
\text { (Freeman) } \\
\text { hvCb }\end{array}$} & \multicolumn{2}{|c|}{$\begin{array}{l}\text { Pittsburah No. } 8 \\
\text { (Delton) } \\
\text { hvAb }\end{array}$} \\
\hline & $\begin{array}{c}\text { As } \\
\text { Received }\end{array}$ & $\begin{array}{l}\text { Dry-Ash- } \\
\text { Free }\end{array}$ & $\begin{array}{c}\text { As } \\
\text { Received }\end{array}$ & $\begin{array}{c}\text { Dry-Ash- } \\
\text { Free }\end{array}$ & $\begin{array}{c}\text { As } \\
\text { Received } \\
\end{array}$ & $\begin{array}{l}\text { Dry-Ash- } \\
\text { Free } \\
\end{array}$ & $\begin{array}{c}\text { As } \\
\text { Received }\end{array}$ & $\begin{array}{c}\text { Dry-Ash- } \\
\text { Free }\end{array}$ \\
\hline $\begin{array}{l}\text { Proximate, Wt. Percent } \\
\text { Moisture (Total) } \\
\text { Volatile Matter } \\
\text { Fixed Carbon } \\
\text { Ash } \\
\text { Total }\end{array}$ & $\begin{array}{r}29.3 \\
30.0 \\
25.5 \\
15.2 \\
100.0\end{array}$ & $\begin{array}{r}54.0 \\
46.0 \\
100.0\end{array}$ & $\begin{array}{r}28.0 \\
32.2 \\
34.2 \\
5.6 \\
100.0\end{array}$ & $\begin{array}{r}-- \\
48.6 \\
51.4 \\
-- \\
100.0\end{array}$ & $\begin{array}{r}19.4 \\
31.3 \\
40.4 \\
8.9 \\
100.0\end{array}$ & $\begin{array}{r}-- \\
43.6 \\
56.4 \\
-- \\
100.0\end{array}$ & $\begin{array}{r}0.8 \\
38.1 \\
52.6 \\
8.5 \\
100.0\end{array}$ & $\begin{array}{c}-- \\
42.1 \\
57.9 \\
-- \\
100.0\end{array}$ \\
\hline $\begin{array}{l}\text { Ultimate, Wt. Percent } \\
\text { Moisture (Total) } \\
\text { Hydrogen } \\
\text { Carbon } \\
\text { Sulfur } \\
\text { Nitrogen } \\
\text { Oxygen (Diff.) } \\
\text { Ash } \\
\text { Total }\end{array}$ & $\begin{array}{r}29.3 \\
3.2 \\
39.4 \\
1.0 \\
0.7 \\
11.2 \\
15.2 \\
100.0\end{array}$ & $\begin{array}{r}-- \\
5.7 \\
71.0 \\
1.9 \\
1.3 \\
20.1 \\
-- \\
100.0\end{array}$ & $\begin{array}{r}28.0 \\
3.5 \\
49.3 \\
0.4 \\
0.8 \\
12.4 \\
5.6 \\
100.0\end{array}$ & $\begin{array}{r}-- \\
5.2 \\
74.3 \\
0.6 \\
7.1 \\
18.8 \\
-- \\
00.0\end{array}$ & $\begin{array}{r}19.4 \\
3.6 \\
53.0 \\
3.0 \\
1.0 \\
11.1 \\
8.9 \\
100.0\end{array}$ & $\begin{array}{r}-- \\
5.1 \\
73.9 \\
4.2 \\
1.4 \\
15.4 \\
\frac{-.}{100.0}\end{array}$ & $\begin{array}{r}0.8 \\
5.1 \\
75.9 \\
2.5 \\
1.4 \\
5.8 \\
8.5 \\
100.0\end{array}$ & $\begin{array}{r}-. \\
5.6 \\
83.7 \\
2.8 \\
1.5 \\
6.4 \\
-- \\
100.0\end{array}$ \\
\hline $\begin{array}{l}\text { Higher Heating Value, } \\
\text { Btu/lb }\end{array}$ & 6920 & 12455 & 8525 & 12845 & 9380 & 13075 & 13655 & 15055 \\
\hline $\begin{array}{l}\text { Ash Loading, Ibs/mm } \\
\text { Btu }\end{array}$ & 21.9 & -- & 6.6 & -- & 9.5 & -- & 6.2 & -- \\
\hline Flammability Index, ${ }^{\circ} \mathrm{F}$ & 930 & -- & 900 & -- & 1010 & -- & 990 & -- \\
\hline $\begin{array}{l}\text { Hardgrove Grindability } \\
\text { Index }\end{array}$ & 64 & -- & 49 & -- & 58 & -- & 63 & -- \\
\hline $\begin{array}{l}\text { Ash Fusibility (Red. } \\
\text { Atm.), }{ }^{\circ} \mathrm{F} \\
\text { I.T. } \\
\text { S.T. } \\
\text { H.T. } \\
\text { F.T. } \\
\Delta T \text { (F.T.-I.T.) }\end{array}$ & $\begin{array}{r}2200 \\
2290 \\
2450 \\
2490 \\
290\end{array}$ & $\begin{array}{l}-- \\
-- \\
-- \\
--\end{array}$ & $\begin{array}{r}2070 \\
2110 \\
2170 \\
2240 \\
170\end{array}$ & $\begin{array}{l}-- \\
-- \\
-- \\
--\end{array}$ & $\begin{array}{r}1980 \\
2040 \\
2210 \\
2260 \\
280\end{array}$ & $\begin{array}{l}-- \\
-- \\
-- \\
--\end{array}$ & $\begin{array}{r}2060 \\
2190 \\
2270 \\
2350 \\
290\end{array}$ & $\begin{array}{l}-- \\
-- \\
-- \\
--\end{array}$ \\
\hline $\begin{array}{l}\text { Ash Composition, } \\
\text { Wt. Percent } \\
\mathrm{SiO}_{2}\end{array}$ & 52.4 & -. & 32.8 & -- & 56.0 & - & 45.6 & $\pi$ \\
\hline $\mathrm{Al}_{2} \mathrm{O}_{3}$ & 17.2 & -- & 15.4 & -- & 16.8 & -- & 19.4 & -- \\
\hline $\mathrm{Fe}_{2} \mathrm{O}_{3}$ & 3.5 & -- & 5.8 & -- & 15.0 & $\cdots$ & 25.6 & $-\cdot$ \\
\hline $\mathrm{CaO}$ & 11.6 & -- & 26.1 & -- & 3.4 & -- & 2.0 & -- \\
\hline $\mathrm{MgO}$ & 1.7 & $\cdots$ & 4.7 & -- & 0.9 & -- & 0.7 & -- \\
\hline $\mathrm{Na}_{2} \mathrm{O}$ & 0.7 & -- & 2.1 & -- & 0.4 & -- & 0.8 & - \\
\hline $\mathrm{K}_{2} \mathrm{O}$ & 0.2 & -- & 0.3 & -- & 1.4 & -- & 1.0 & -- \\
\hline $\mathrm{TiO}_{2}$ & 2.5 & -- & 1.1 & -- & 0.8 & - & 1.2 & -- \\
\hline $\mathrm{SO}_{3}$ & 10.8 & -- & 11.6 & -- & 4.0 & -- & $\underline{2.5}$ & -- \\
\hline Total & 100.0 & & 100.0 & & 100.0 & & 100.0 & \\
\hline
\end{tabular}


$\mathrm{Fe}_{2} \mathrm{O}_{3}$ content). Each of the fuels, with the exception of the Texas lignite, has a relatively low ash fusibility temperature. The Illinois coal ash has a moderately high iron content $\left(15 \% \mathrm{Fe}_{2} \mathrm{O}_{3}\right)$ while the Pittsburgh coal ash has a very high iron content $\left(26 \% \mathrm{Fe}_{2} \mathrm{O}_{3}\right)$. The Wyoming coal ash has a moderate sodium content (2.1\% $\mathrm{Na}_{2} \mathrm{O}$ ) and relatively high calcium content ( $26 \% \mathrm{CaO}$ ). These features are probably largely responsible for the relatively low ash fusibility temperatures.

\section{Char Characteristics}

Analyses. Proximate and ultimate analyses of the size graded chars are given in Table 4-2 along with those of the $200 \times 400$ mesh air-dried size fractions of their corresponding parent coals. Proximate and ultimate analyses of the feed samples were used in conjunction with those of partially reacted chars to determine combustion, gasification, and pyrolysis efficiencies, and carbon mass balance in the Drop Tube Furnace System.

Particle Size Distributions. Two methods were used to determine the particle size distributions of the feed samples. Dry sieve analysis was used for the 200 $\times 400$ mesh size fractions, and Coulter counter was used for -400 mesh size fractions. These data were analyzed by the Rosin-Rammler method (17) to determine the fineness factor $\left(X^{\prime}\right)$, dispersion factor $(n)$, and mean weight particle size $(\bar{X})$ of all the samples. Results are given in Table 4-3 along with those from the $200 \times 400$ mesh size cuts of the parent coals.

Table 4-3 shows that $\bar{x}$ for the $200 \times 400$ mesh coal and char samples are in the 50-55 $\mu \mathrm{m}$ range. It is important to note that $\bar{x}$ for the -400 mesh fraction obtained from grinding a portion of $200 \times 400$ mesh is $32 \%$ smaller than that of the -400 mesh fraction obtained from size grading the whole PSC char ( $13 \mathrm{vs.} 19 \mu \mathrm{m}$ ). This finding indicates that grinding the chars created smaller particles than those from -400 mesh obtained from size grading of char.

Pore Surface Areas. The BET $\left(\mathrm{N}_{2}\right)$ and $\mathrm{CO}_{2}$ specific pore surface areas of the size graded chars are presented in Table 4-4. Both of these surface areas increase with decreasing rank of the parent coal. The BET surface areas of the $200 \times 400$ mesh samples increase from 13 to $213 \mathrm{~m}^{2} / \mathrm{g}$ (dry-ash-free basis) as the parent coal ranks decrease from Pittsburgh hvAb coal to Texas lignite. The corresponding increase in the $\mathrm{CO}_{2}$ surface area is in the same range $\left(13-200 \mathrm{~m}^{2} / \mathrm{g}\right)$. 
Table 4-2

PROXIMATE AND ULTIMATE AMALYSES OF SIZE GRADED COALS AND CHARS

\begin{tabular}{|c|c|c|c|c|c|c|c|c|c|c|c|c|}
\hline \multirow[b]{2}{*}{ Analysis } & \multicolumn{2}{|c|}{$\begin{array}{l}\text { Texas } \\
\text { (Monticello) } \\
\text { Lignite A }\end{array}$} & \multicolumn{3}{|c|}{$\begin{array}{l}\text { Wyoming } \\
\text { (Jacobs Ranch Range) } \\
\text { Sub C }\end{array}$} & \multicolumn{3}{|c|}{$\begin{array}{c}\text { IITnois Ko. } 6 \\
\text { (Freeman) } \\
\text { hvCb }\end{array}$} & \multicolumn{3}{|c|}{$\begin{array}{c}\text { Pittsburgh No. } 8 \\
\text { (Del ton) } \\
\text { hvAb }\end{array}$} & \multirow[b]{2}{*}{$\begin{array}{l}-400 \\
\text { Mesh } \\
\text { Char }\end{array}$} \\
\hline & $\begin{array}{l}200 \times 400 \\
\text { Mesh } \\
\text { Coal }\end{array}$ & $\begin{array}{l}200 \times 400 \\
\text { Mesh } \\
\text { Char }\end{array}$ & $\begin{array}{l}200 \times 400 \\
\text { Mesh } \\
\text { Coal }\end{array}$ & $\begin{array}{l}200 \times 400 \\
\text { Mesh } \\
\text { Char }\end{array}$ & $\begin{array}{l}-400 \\
\text { Mesh } \\
\text { Char }\end{array}$ & $\begin{array}{l}200 \times 400 \\
\text { Mesh } \\
\text { Coal }\end{array}$ & $\begin{array}{l}200 \times 400 \\
\text { Mesh } \\
\text { Char }\end{array}$ & $\begin{array}{l}-400 \\
\text { Mesh } \\
\text { Char }\end{array}$ & $\begin{array}{l}200 \times 400 \\
\text { Mesh } \\
\text { Coal }\end{array}$ & $\begin{array}{l}200 \times 400 \\
\text { Mesh } \\
\text { Char }\end{array}$ & $\begin{array}{l}-400 \\
\text { Mesh } \\
\text { Char } 1\end{array}$ & \\
\hline \multicolumn{13}{|c|}{ Proximate, Wt. Percent } \\
\hline Moisture & 6.0 & 0.1 & 5.4 & 0.7 & 0.5 & 4.0 & 0.6 & 0.5 & 1.2 & 0.3 & 0.4 & 0.2 \\
\hline Volatile Matter & 39.8 & 4.1 & 41.3 & 4.6 & 7.0 & 37.6 & 2.7 & 3.9 & 39.3 & 1.4 & 1.7 & 1.1 \\
\hline Fixed Carbon & 35.5 & 59.8 & 47.4 & 83.3 & 80.3 & 50.2 & 82.3 & 80.0 & 51.8 & 84.2 & 83.7 & 89.9 \\
\hline Ash & 18.7 & 36.0 & 5.9 & 11.4 & 12.2 & 8.2 & 14.4 & 15.6 & 7.7 & 14.1 & 14.2 & 8.8 \\
\hline Total & 100.0 & 100.0 & 100.0 & 100.0 & 100.0 & 100.0 & 100.0 & 100.0 & 100.0 & 100.0 & 100.0 & 100.0 \\
\hline \multicolumn{13}{|c|}{ Ultimate, Wt. Percent } \\
\hline Moisture & 6.0 & 0.1 & 5.4 & 0.7 & 0.5 & 4.0 & 0.6 & 0.5 & 1.2 & 0.3 & 0.4 & 0.2 \\
\hline Hydrogen & 4.2 & 0.2 & 4.8 & 0.3 & 0.3 & 4.5 & 0.5 & 0.2 & 5.3 & 0.3 & 0.3 & 0.2 \\
\hline Carbon & 58.7 & 61.6 & 62.0 & 76.9 & 79.6 & 64.3 & 76.9 & 76.0 & 74.5 & 82.1 & 82.0 & 88.2 \\
\hline Sulfur & 1.4 & 1.4 & 0.6 & 0.5 & 0.6 & 3.1 & 2.1 & 2.1 & 2.9 & 1.6 & 1.7 & 1.7 \\
\hline Nitrogen & 0.1 & 0.5 & 0.9 & 0.5 & 0.5 & 1.2 & 0.9 & 0.7 & 1.4 & 0.9 & 1.1 & 0.7 \\
\hline Oxygen (Diff) & 10.9 & 0.2 & 19.5 & 9.7 & 6.3 & 14.7 & 4.6 & 4.9 & 7.0 & 0.7 & 0.3 & 0.2 \\
\hline Ash & 18.7 & 36.0 & 6.8 & 11.4 & 12.2 & 8.2 & 14.4 & 15.6 & 7.7 & 14.1 & 14.2 & 8.8 \\
\hline Total & 100.0 & 100.0 & $\overline{100.0}$ & 100.0 & $\overline{100.0}$ & 100.0 & $\overline{100.0}$ & $\overline{100.0}$ & $\overline{100.0}$ & $\overline{100.0}$ & $\overline{100.0}$ & $\overline{100.0}$ \\
\hline
\end{tabular}

1. Samples obtained by grinding portions of $200 \times 400$ mesh chars.

2. Samples obtained by size grading the whole chars. 
Table 4-3

PARTICLE SIZE DISTRIBUTIONS FOR SIZE GRADED COALS AND CHARS

(a) Dry-Sieve Analyses on $200 \times 400$ Mesh Samples

\begin{tabular}{|c|c|c|c|c|c|c|c|c|}
\hline \multirow{3}{*}{ 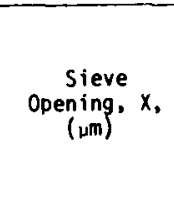 } & \multicolumn{6}{|c|}{ Cummulative Weight Percent Greater Than $X$} & & \\
\hline & \multicolumn{2}{|c|}{$\begin{array}{l}\text { Texas } \\
\text { (Monticello) } \\
\text { Lignite }\end{array}$} & \multicolumn{2}{|c|}{$\begin{array}{l}\text { Wyoming } \\
\text { (Jacobs Ranch Range) } \\
\text { Sub C }\end{array}$} & \multicolumn{2}{|c|}{$\begin{array}{c}111 \text { inois No: } 6 \\
\text { (Freeman) } \\
\text { hvCb }\end{array}$} & \multicolumn{2}{|c|}{$\begin{array}{c}\text { Pittsburgh No. } 8 \\
\text { (Delton) } \\
\text { hvAb }\end{array}$} \\
\hline & Coal & Char & Coal & Char & Coal & Char & Coal & Char \\
\hline $\begin{array}{l}75 \\
63 \\
53 \\
44 \\
38\end{array}$ & $\begin{array}{r}1.7 \\
16.9 \\
41.2 \\
88.0 \\
98.2\end{array}$ & $\begin{array}{r}0.6 \\
4.1 \\
25.4 \\
81.3 \\
98.1\end{array}$ & $\begin{array}{r}0.3 \\
16.1 \\
51.6 \\
73.1 \\
98.1\end{array}$ & $\begin{array}{r}0.0 \\
4.2 \\
27.0 \\
56.7 \\
95.7\end{array}$ & $\begin{array}{r}0.3 \\
14.1 \\
46.6 \\
68.8 \\
97.5\end{array}$ & $\begin{array}{r}0.3 \\
11.9 \\
49.5 \\
88.6 \\
97.1\end{array}$ & $\begin{array}{r}0.6 \\
15.1 \\
48.8 \\
85.5 \\
96.6\end{array}$ & $\begin{array}{r}0.8 \\
10.5 \\
45.1 \\
75.5 \\
98.1\end{array}$ \\
\hline \multicolumn{9}{|l|}{$\begin{array}{l}\text { Rosin-Ranmler } \\
\text { Parameters }\end{array}$} \\
\hline$x^{\prime} \stackrel{n}{(\mu m)}^{n}$ & $\begin{array}{r}7.5 \\
58.0\end{array}$ & $\begin{array}{r}7.5 \\
54.0\end{array}$ & $\begin{array}{r}9.0 \\
57.0\end{array}$ & $\begin{array}{r}7.6 \\
54.0\end{array}$ & $\begin{array}{r}8.0 \\
58.0\end{array}$ & $\begin{array}{r}8.0 \\
58.0\end{array}$ & $\begin{array}{r}7.1 \\
57.0\end{array}$ & $\begin{array}{r}7.1 \\
57.0\end{array}$ \\
\hline $\bar{x} \quad(\mu m)$ & 55.0 & 57.0 & 54.0 & 51.0 & 55.0 & 55.0 & 53.0 & 53.0 \\
\hline
\end{tabular}

(b) Coulter-Counter Analyses on -400 Mesh Samples

\begin{tabular}{|c|c|c|c|c|}
\hline \multirow[b]{2}{*}{$\begin{array}{c}\begin{array}{c}\text { Sieve } \\
\text { Opening, } \\
(\mu \mathrm{m})\end{array} \\
\mathrm{x},\end{array}$} & \multicolumn{3}{|c|}{ Cummulative Weight Percent Greater than $X$} & \multirow[b]{2}{*}{$\begin{array}{c}\text { Pittsburgh No. } 8 \\
\text { Char }^{8}\end{array}$} \\
\hline & $\begin{array}{l}\text { Wyoming } \\
\text { JRC Char }\end{array}$ & $\underset{\text { Char }}{\text { Illinois,No. } 6}$ & $\begin{array}{c}\text { Pittsburgh No. } 8 \\
\text { Char }\end{array}$ & \\
\hline $\begin{array}{r}32.0 \\
25.4 \\
20.2 \\
16.0 \\
12.7 \\
10.1 \\
8.0 \\
6.4 \\
5.0 \\
4.0 \\
3.2\end{array}$ & $\begin{array}{r}1.0 \\
3.5 \\
9.5 \\
17.0 \\
27.0 \\
37.5 \\
49.0 \\
61.0 \\
73.5 \\
84.0 \\
93.5\end{array}$ & $\begin{array}{r}3.0 \\
6.0 \\
10.0 \\
16.0 \\
24.0 \\
33.0 \\
43.5 \\
55.0 \\
67.5 \\
80.0 \\
91.0\end{array}$ & $\begin{array}{r}2.0 \\
9.5 \\
17.0 \\
26.0 \\
38.5 \\
51.5 \\
64.0 \\
75.0 \\
83.0 \\
90.0 \\
96.0\end{array}$ & $\begin{array}{l}19.0 \\
30.5 \\
37.5 \\
43.0 \\
48.5 \\
56.5 \\
60.0 \\
66.0 \\
74.0 \\
83.0 \\
92.5\end{array}$ \\
\hline \multicolumn{5}{|l|}{$\begin{array}{l}\text { Rosin-Rammler } \\
\text { Parameters }\end{array}$} \\
\hline$x \cdot \stackrel{n}{(n m)}$ & $\begin{array}{r}1.6 \\
10.5\end{array}$ & $\begin{array}{r}1.3 \\
10.0\end{array}$ & $\begin{array}{r}1.6 \\
14.0\end{array}$ & $\begin{array}{r}0.9 \\
18.0\end{array}$ \\
\hline $\bar{x}(u m)$ & 9.0 & 9.0 & 13.0 & 19.0 \\
\hline
\end{tabular}

1. From grinding a $200 \times 400$ mesh char.

2. From size grading a whole char. 
Table $4-4$

SURFACE AREA $\left(S_{X}\right)$ AND REACTIVITY PARAMETER $\left(R_{T}\right)$ RESULTS FOR COAL CHARS

\begin{tabular}{|c|c|c|c|c|c|c|c|c|c|}
\hline \multirow{2}{*}{\multicolumn{2}{|c|}{ Parameter }} & \multirow{2}{*}{$\begin{array}{l}\text { Monticello } \\
\text { Lignite Char } \\
200 \times 400 \text { Mesh }\end{array}$} & \multicolumn{2}{|c|}{ JRC Char } & \multicolumn{2}{|c|}{$\begin{array}{c}\text { I1Tino is No. } 6 \\
\text { Char }\end{array}$} & \multicolumn{3}{|c|}{$\begin{array}{c}\text { Pittsburgh No. } 8 \\
\text { Char }\end{array}$} \\
\hline & & & $\begin{array}{l}200 \times 400 \\
\text { Mesh }\end{array}$ & $\begin{array}{l}-400 \\
\text { Mesh }\end{array}$ & $\begin{array}{l}200 \times 400 \\
\text { Mesh }\end{array}$ & $\begin{array}{l}-400 \\
\text { Mesh }\end{array}$ & $\begin{array}{l}200 \times 400 \\
\text { Mesh }\end{array}$ & $\begin{array}{l}-400 \\
\text { Mesh }\end{array}$ & $\begin{array}{l}-400 \\
\text { Mesh }^{2}\end{array}$ \\
\hline \multicolumn{10}{|c|}{ Surface Area, $\mathrm{S}_{\mathrm{x}}, \mathrm{m}^{2} / \mathrm{g}$} \\
\hline \multirow[t]{2}{*}{$\cdot \mathrm{S}_{\mathrm{BET}}:$} & $\begin{array}{l}\text { Dry Basis } \\
\text { Dry-Ash-Free }\end{array}$ & 135.0 & 84.9 & 112.2 & 45.5 & 70.0 & 11.9 & 20.4 & 23.3 \\
\hline & Bas is & 213.0 & 97.4 & 128.8 & 54.4 & 83.7 & 12.9 & 24.0 & 25.6 \\
\hline \multirow[t]{2}{*}{$\cdot \mathrm{SCO}_{2}:$} & Dry Basis & 126.6 & 164.9 & 166.4 & 67.0 & 115.5 & 10.9 & 16.4 & 8.0 \\
\hline & Basis & 200.0 & 189.1 & 191.0 & 80.1 & 138.4 & 12.7 & 19.3 & 8.8 \\
\hline
\end{tabular}

TGA Reactivity Parameter,

$\mathrm{R}_{\mathrm{T}}, \mathrm{mg} \min ^{-1} \mathrm{mg}^{-1}$

- $R_{700}$ (in air at $700^{\circ} \mathrm{C}$ )

0.379

0.362

0.329

0.359

0.363

$\begin{array}{llll}0.322 & 0.336 & 0.339\end{array}$

$\cdot \mathrm{R}_{950}$ (in $\mathrm{CO}_{2}$ at $950^{\circ} \mathrm{C}$ )

0.153

0.1043

$0.0813 \quad 0.0223$

0.0148

$0.00398 \quad 0.00558 \quad 0.00330$

1. From $200 \times 400$ Mesh Char.

2. From size grading of a whole char. 
It is interesting to note that while the BET and $\mathrm{CO}_{2}$ surface areas of the $200 \mathrm{x}$ 400 mesh Pittsburgh (PSC) and Texas lignite (TXL) chars are comparable (12.9 vs. $12.7 \mathrm{~m}^{2} / \mathrm{g}$ and 213 vs. $200 \mathrm{~m}^{2} / \mathrm{g}$, respectively), those from I11inois (ILC) and Jacobs Ranch Range (JRC) chars are not (54 vs. $80 \mathrm{~m}^{2} / \mathrm{g}$ and $97 \mathrm{vs} .189 \mathrm{~m}^{2} / \mathrm{g}$, respectively). These results indicate that: (1) carbon dioxide is as inaccessible as nitrogen to the relatively non-porous PSC char; (2) carbon dioxide is as accessible as nitrogen to the relatively porous TXL char; and (3) the pores in the JRC and ILC chars are predominantly in the molecular size range to which $\mathrm{CO}_{2}$ is known to be more accessible (18).

Results in Table 4-4 also show that grinding $200 \times 400$ mesh fractions to -400 mesh increases internal surface areas of the materials (for example, the BET surface area of the PSC char increases by $85 \%$ from 13 to $24 \mathrm{~m}^{2} / \mathrm{g}$ ).

Since the fuel reactivity is dependant upon the internal surface area, these results indicate two important points: (1) the finer the particle size, the more reactive the char is expected to be; and (2) the lower the rank of the parent coal, the higher the char reactivity is expected to be.

Thermo-Gravimetric Reactivities. Thermo-gravimetric burn-off curves in air at $700^{\circ} \mathrm{C}\left(1292^{\circ} \mathrm{F}\right)$ for $200 \times 400$ mesh chars are given in Figure $4-1$. The following reactivity $(\eta)$ trend emerges: $\eta_{T X L C}>\eta_{\text {JRCC }} \approx \eta_{\text {ILCC }}>\eta_{\text {PSCC }}$. That is, Texas lignite char is the most reactive, followed by Jacobs Ranch Range and Illinois chars which are comparable, and Pittsburgh char is the least reactive char.

Carbon gasification reaction in carbon dioxide is endothermic and sluggish principally at low temperatures (19). In this study, it was found that $700^{\circ} \mathrm{C}$ was too low a temperature for char gasification studies in the TGA. Hence, this particular study was conducted at $950^{\circ} \mathrm{C}\left(1742^{\circ} \mathrm{F}\right)$. Results are shown in Figure 4-2.

The following trend was observed: $\eta_{\text {TXLC }}>\eta_{\text {JRCC }}>\eta_{\text {ILCC }}>\eta_{\text {PSCC }}$. It should be noted that the gasification reactions are much slower than the combustion reactions and that differences in reactivities between the chars are wider than those found in combustion. After 82 minutes, both lignite and subbituminous chars are gasified to completion, whereas Illinois and Pittsburgh chars are gasified only to $73 \%$ and $32 \%$, respectively. During combustion all reactions are complete within 8 minutes. 


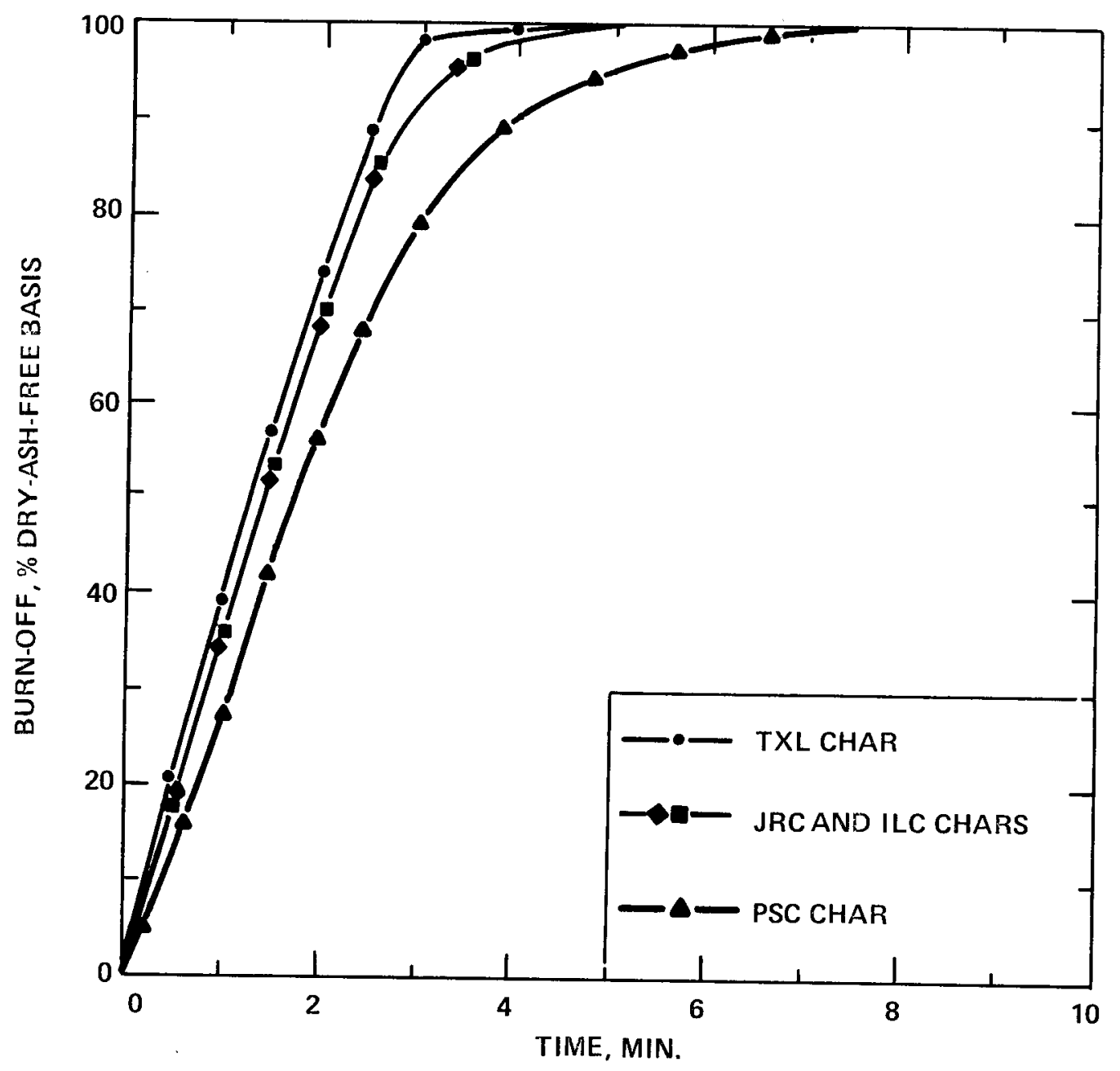

FIGURE 4-1 THERMO-GRAVIMETRIC BURN-OFF CURVES IN AIR AT $700^{\circ} \mathrm{C}$ FOR VARIOUS $200 \times 400$ MESH DTFS CHARS 


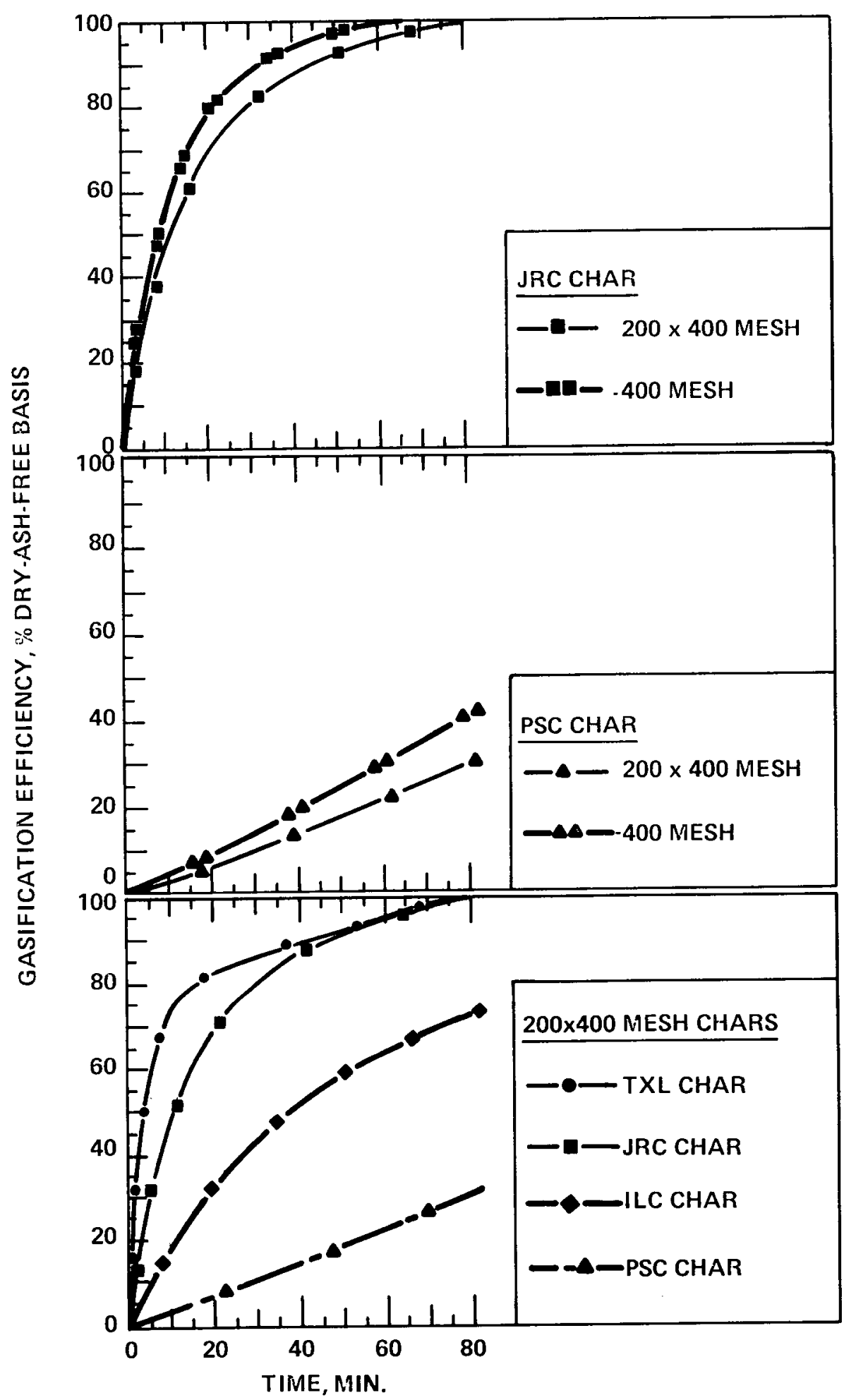

FIGURE 4-2 THERMIO-GRAVIMETRIC GASIFICATION CURVES IN CARBON DIOXIDE AT $950^{\circ} \mathrm{C}$ FOR VARIOUS CHARS 
The effect of particle size on the gasification reactivites of JRC and PSC chars was also studied. In both cases, the -400 mesh size fraction (obtained by grinding a portion of $200 \times 400$ mesh size fraction) is relatively more reactive than the $200 \times 400$ mesh size fraction as clearly depicted in Figure 4-2.

Surface Area-Reactivity Relationships. The results presented above show that the internal pore surface area of a char plays a major role in determining its combustion or gasification characteristics. Surface area $\left(S_{X}\right)$ - Reactivity parameter $\left(R_{T}\right)$ data are presented in Table 4-4. Plots of $S_{B E T}$ vs. $R_{T}$ (which indicates the maximum weight loss rate per unit weight of starting material) are shown in Figure 4-3. They indicate that as the BET surface areas increase from 13 to 213 $\mathrm{m}^{2} / \mathrm{g}$, the reactivity parameters increase from 0.322 to $0.379 \mathrm{mg} \mathrm{min}^{-1} \mathrm{mg}^{-1}$ in air and from 0.00398 to $0.153 \mathrm{mg} \mathrm{min} \mathrm{mg}^{-1}$ in carbon dioxide. That is, the higher the char surface area, the higher is its normalized maximum combustion or gasification rate. Results also indicate that maximum gasification rate is much more sensitive to surface area than is maximum combustion rate.

PYROLYSIS, COMBUSTION, AND GASIFICATION OF COALS AND CHARS IN THE DROP TUBE FURNACE SYSTEM (DTFS)

The controls of the DTFS are designed to maintain the wall temperatures of the preheater and test furnace at certain values. These values dictate the ultimate gas temperature profiles in the reaction zone of the test furnace. A small suction pyrometer was used to measure all the gas temperature profiles.

Results are shown in Figure 4-4. Gas temperatures are seen to rise and to leveloff after a certain distance. The isothermal zone is located within the last eight to ten inches of the sixteen-inch reaction zone. These isothermal temperatures are the ones that are referred to throughout this report. Example, $T_{5}=$ $2650^{\circ} \mathrm{F}$ indicates that the isothermal zone was at this temperature. A11 the temperature profiles used for obtaining char combustion and gasification kinetics are given in Figure $4-4$.

\section{Pyrolysis of Coals and Char}

The $200 \times 400$ mesh size fraction of each parent coal was pyrolyzed in nitrogen at $2650^{\circ} \mathrm{F}$ and chars were collected at 16 -inch reaction zone. The objective of this experiment was to determine the swelling factor $(\alpha)$ and the Q-factor of each coal. 


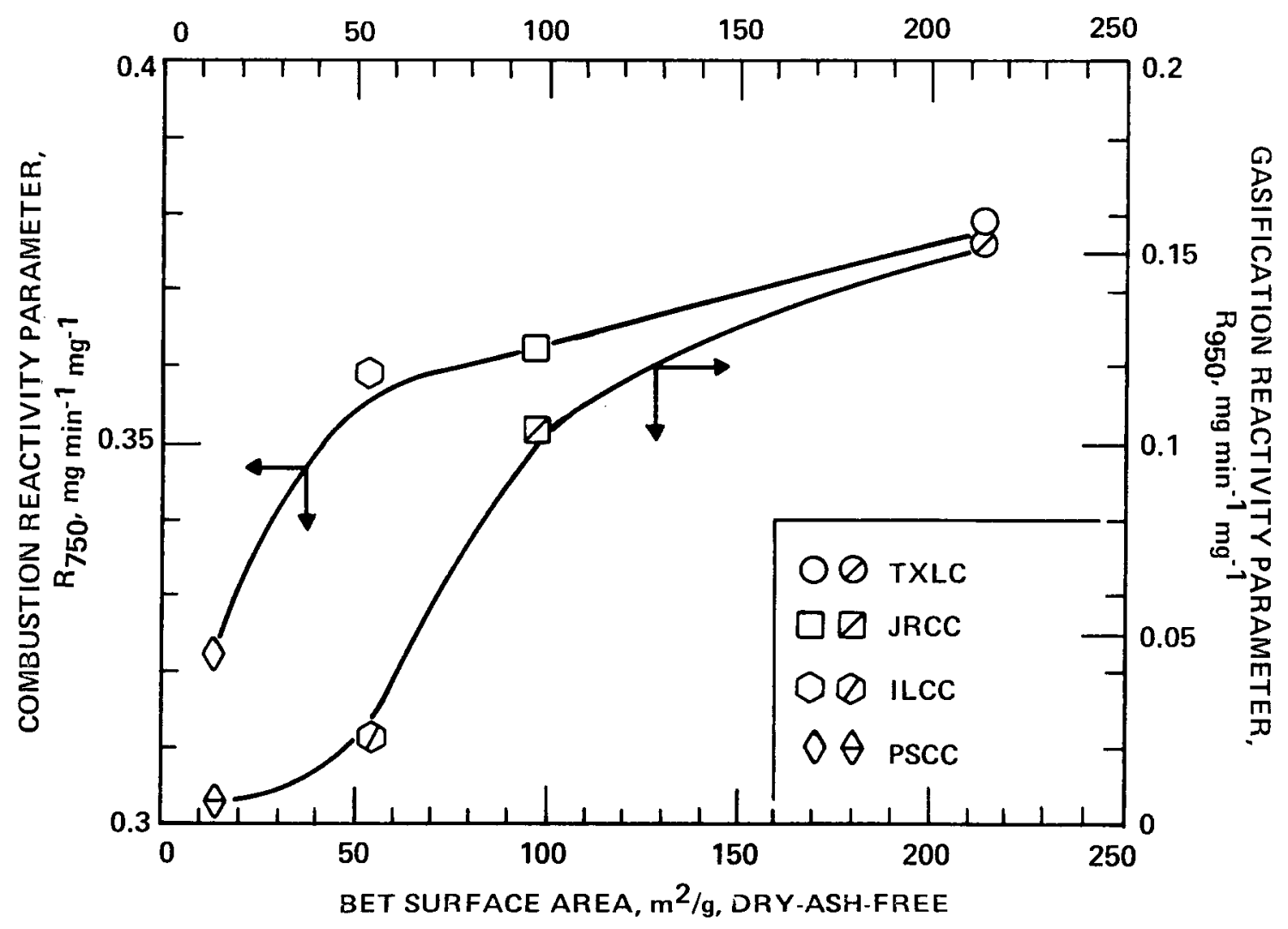

FIGURE 4-3 INFLUENCE OF BET PORE SURFACE AREA ( $S_{B E T}$ ) ON TGA COMBUSTION AND GASIFICATION REACTIVITY PARAMETERS $\left(\mathrm{R}_{\mathrm{T}}\right)$ FOR $200 \times 400$ MESH CHARS 


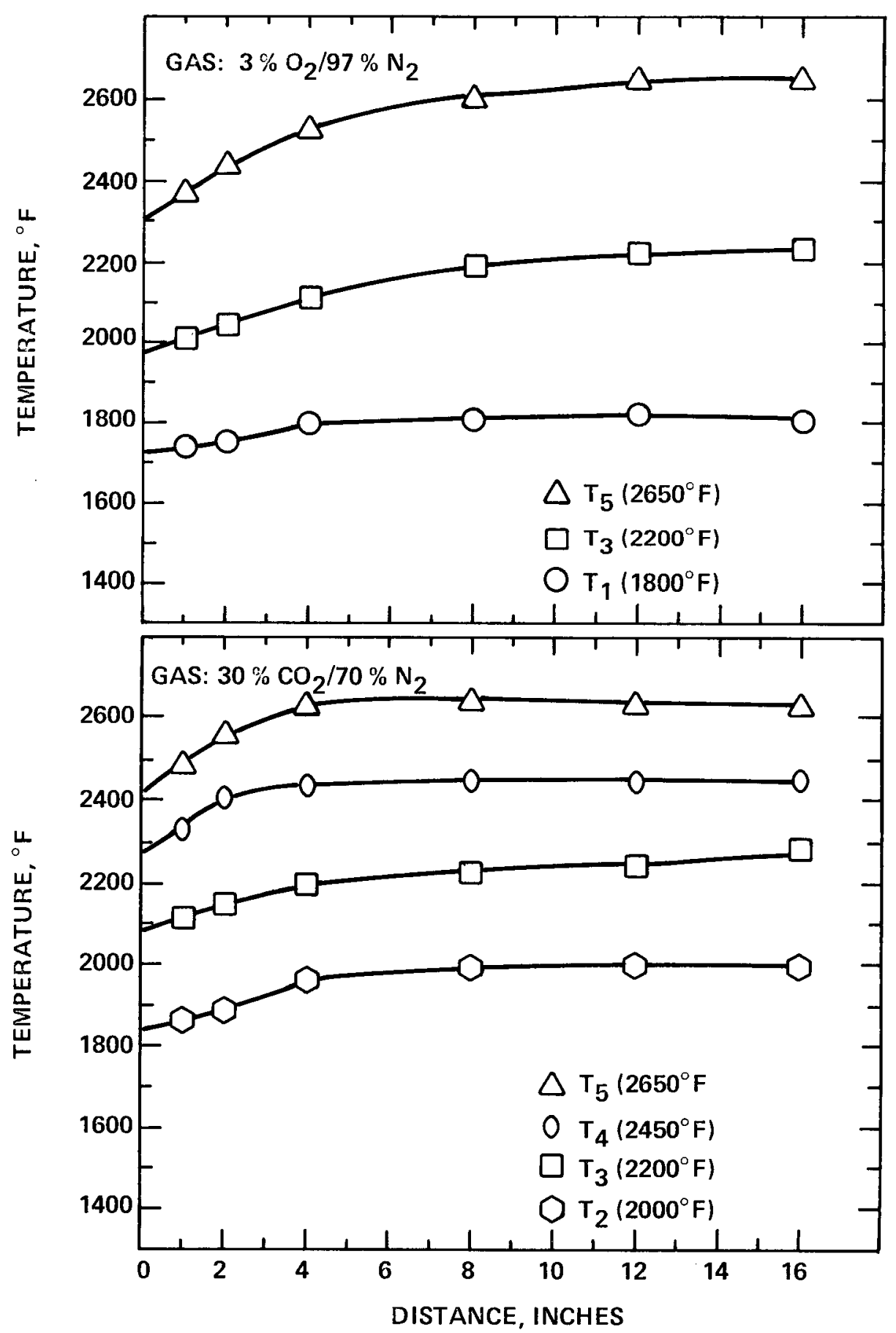

FIGURE 4-4 AXIAL GAS TEMPERATURE PROFILES IN THE DROP TUBE FURNACE SYSTEM REACTION ZONE 
The swelling factor is defined as the ratio of the mean weight particle size of the 16-inch char $\left(\underline{\bar{x}}_{16}\right)$ to that of the feed coal $\left(\bar{x}_{0}\right)$. Results (Tab1e 4-5) indicate values of $1.4,1.0,1.0$, and 0.8 for the PSC, ILC, JRC, and TXL coals, respectively. That is, the PSC coal swelled by $40 \%$, both the ILC and JRC did not swell, and the TXL actually showed particle decrepitation (20\% reduction in size). Results (Table 4-6) on the PSC coal indicate that most of the swelling takes place very early, at the one-inch reaction zone (ca. 40 milliseconds). The $200 \times 400$ mesh size fraction of the PSC char was also pyrolyzed in nitrogen. Results in Table 4-6 show, as expected, no swelling of char throughout the reaction zone. These $\alpha$ values are important input data in any modelling studies of these coals.

The Q-factor is simply the ratio of the dry-ash-free weight loss at 16-inch reaction zone $\left(V_{16}\right)$ to the dry-ash-free ASTM volatile matter $\left(V_{0}\right)$. Results, Table 4-7, show Q-factors of 1.2, 1.1, 1.0, and 1.0, for the PSC, ILC, JRC, and TXL coals, respectively. The PSC and ILC coals show, respectively, a $20 \%$, and $10 \%$ enhancement in the volatile matter yield in the entrained-flow DTFS over ASTM values. Both JRC and TXL coals show no substantial changes between the ASTM and DTFS volatile matter yields. These data are also important in evaluating the extents of devolatilization of these coals for modelling purposes.

Combustion of Coals

The combustion of $200 \times 400$ mesh size fractions of coals was studied in $3 \% \mathrm{O}_{2} /$ $97 \% \mathrm{~N}_{2}$ (\% by volume) at 1800 and $2650^{\circ} \mathrm{F}$ gas temperatures. Combustion efficiency results, plotted in Figure 4-5, show the importance of temperature and nature of coal on coal combustion efficiencies $(\eta)$. The following trend is observed:

$\eta_{T X L}=\eta_{J R C}>\eta_{I L C}>\eta_{P S C}$. More specifically: (1) at $1800^{\circ} \mathrm{F}$ and $0.6 \mathrm{sec} ., \eta_{J R C}=$ $78 \%, \eta_{I L C}=69 \%$, and $\eta_{P S C}=61 \%$; and (2) at $2650^{\circ} \mathrm{F}$ and $0.6 \mathrm{sec}, \eta_{T X L}=98 \%, \eta_{J R C}=$ $98 \%, \eta_{I L C}=95 \%$, and $\eta_{P S C}=85 \%$.

Figure 4-5 shows that the trend given above is due solely to differences in char burn-out rates rather than to differences in devolatilization rates. In fact, devolatilization rates in the early stages of combustion of these coals are found to be similar at $2650^{\circ} \mathrm{F}$; at $1800^{\circ} \mathrm{F}$, the devolatilization rate of the Pittsburgh coal is more rapid than those of the other coals. Computer printouts of coal combustion data are given in Appendix $\mathrm{C}$. 
Table 4-5

SWELLING FACTORS OF COALS DURING DTFS PYROLYSIS IN NITROGEN AT $2650^{\circ} \mathrm{F}$ GAS TEMPERATURE

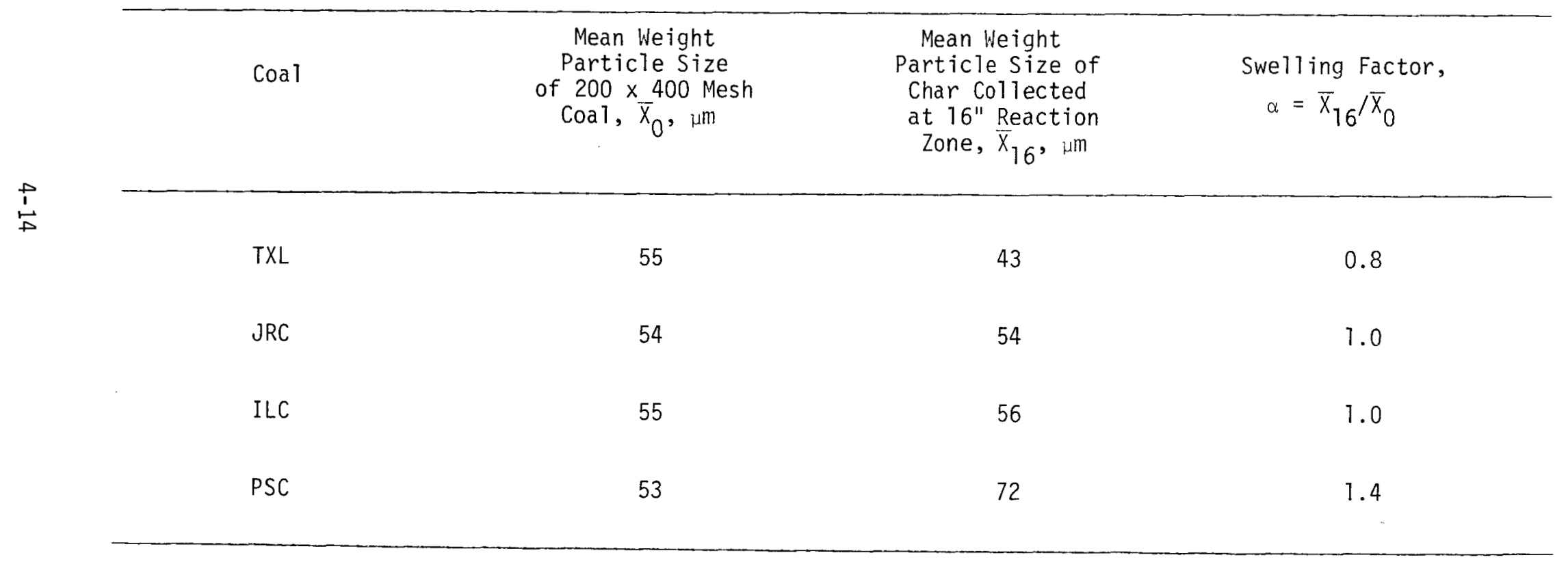


Table 4-6

PARTICLE SIZE CHANGES DURING PYROLYSIS IN NITROGEN AT $2650^{\circ} \mathrm{F}$ FOR PITTSBURGH SEAM COAL AND CHAR ${ }^{\prime}$

\begin{tabular}{|c|c|c|c|c|c|c|c|c|c|c|c|c|c|c|}
\hline \multirow{3}{*}{ 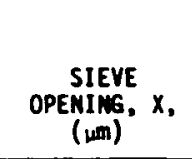 } & \multicolumn{13}{|c|}{ CUMMULATIVE WEIGHT PERCENT GREATER THAN $X$} & \\
\hline & \multicolumn{6}{|c|}{ COAL (TEST NO. PSC-II-5) } & \multicolumn{8}{|c|}{ CHAR (TEST NO. PSCC-IV-5) } \\
\hline & $0^{\prime \prime 1}$ & e 1" & (2" & (" & $8 "$ & $12 "$ & (16" & $0^{11}$ & ?" & $2 "$ & 4" & $8 "$ & e 12" & e 16" \\
\hline 75 & 0.6 & 43.5 & 56.4 & 41.8 & 34.5 & 38.2 & 45.1 & 0.7 & 0.6 & 0.7 & 0.5 & 0.8 & 0.4 & 0.3 \\
\hline 44 & 85.5 & 86.8 & 88.5 & 75.6 & 72.5 & 72.9 & 80.3 & 70.0 & 71.0 & 74.3 & 77.0 & 77.2 & 80.3 & 82.6 \\
\hline 38 & 96.6 & 95.1 & 96.3 & 90.5 & 91.0 & 91.5 & 93.7 & 95.5 & 93.3 & 95.2 & 96.9 & 93.3 & 96.4 & 97.4 \\
\hline & \multicolumn{14}{|c|}{$\begin{array}{l}\text { ROSIN-RAYMLER } \\
\text { PARAMETERS } \\
\end{array}$} \\
\hline$n$ & 7.1 & 3.5 & 3.9 & 2.9 & 3.3 & 3.3 & 3.4 & 6.0 & 5.5 & 6.3 & 6.5 & 6.0 & 7.5 & 7.5 \\
\hline$X^{\prime} \quad(\mu \pi)$ & 57.0 & 80.0 & 87.0 & 78.0 & 71.0 & 78.0 & 80.0 & 57.0 & 56.0 & 58.0 & 59.0 & 59.0 & 58.0 & 58.0 \\
\hline $\bar{X}(\mu m)$ & 53.0 & 72.0 & 79.0 & 70.0 & 64.0 & 70.0 & 72.0 & 53.0 & 52.0 & 54.0 & 55.0 & 55.0 & 55.0 & 55.0 \\
\hline
\end{tabular}

1. Feed Sample 
Table 4-7

COMPARISON BETWEEN ASTM VOLATILE MATTERS OF COALS AND THEIR DTFS PYROLYSIS WEIGHT LOSSES IN NITROGEN AT $2650^{\circ} \mathrm{F}$ GAS TEMPERATURE

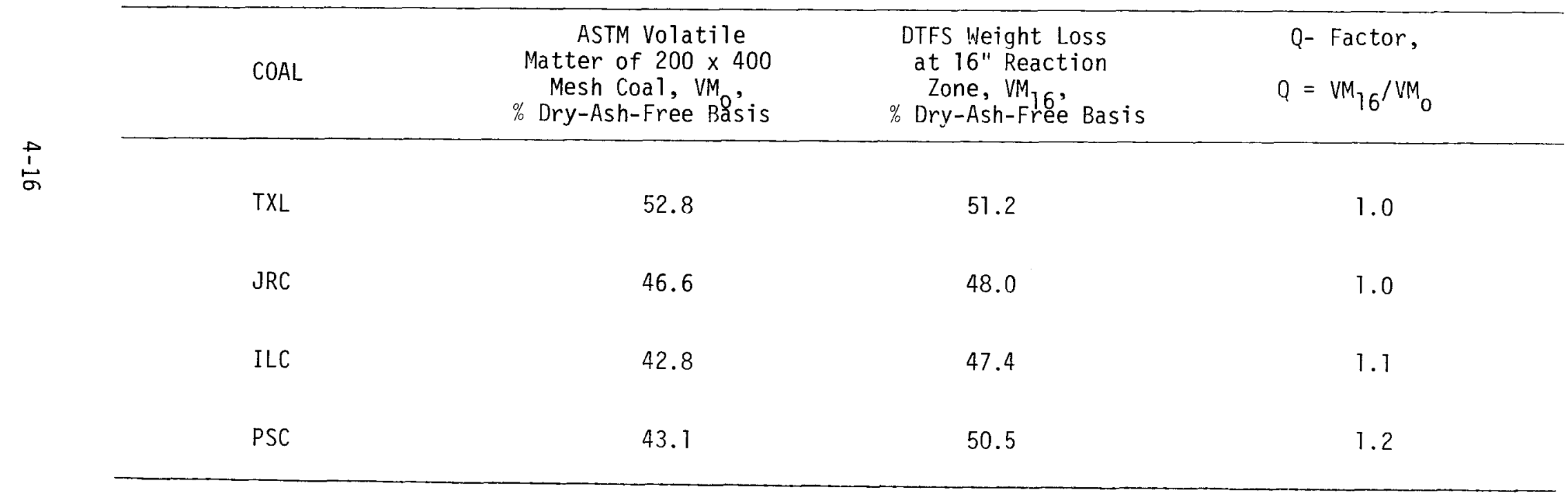




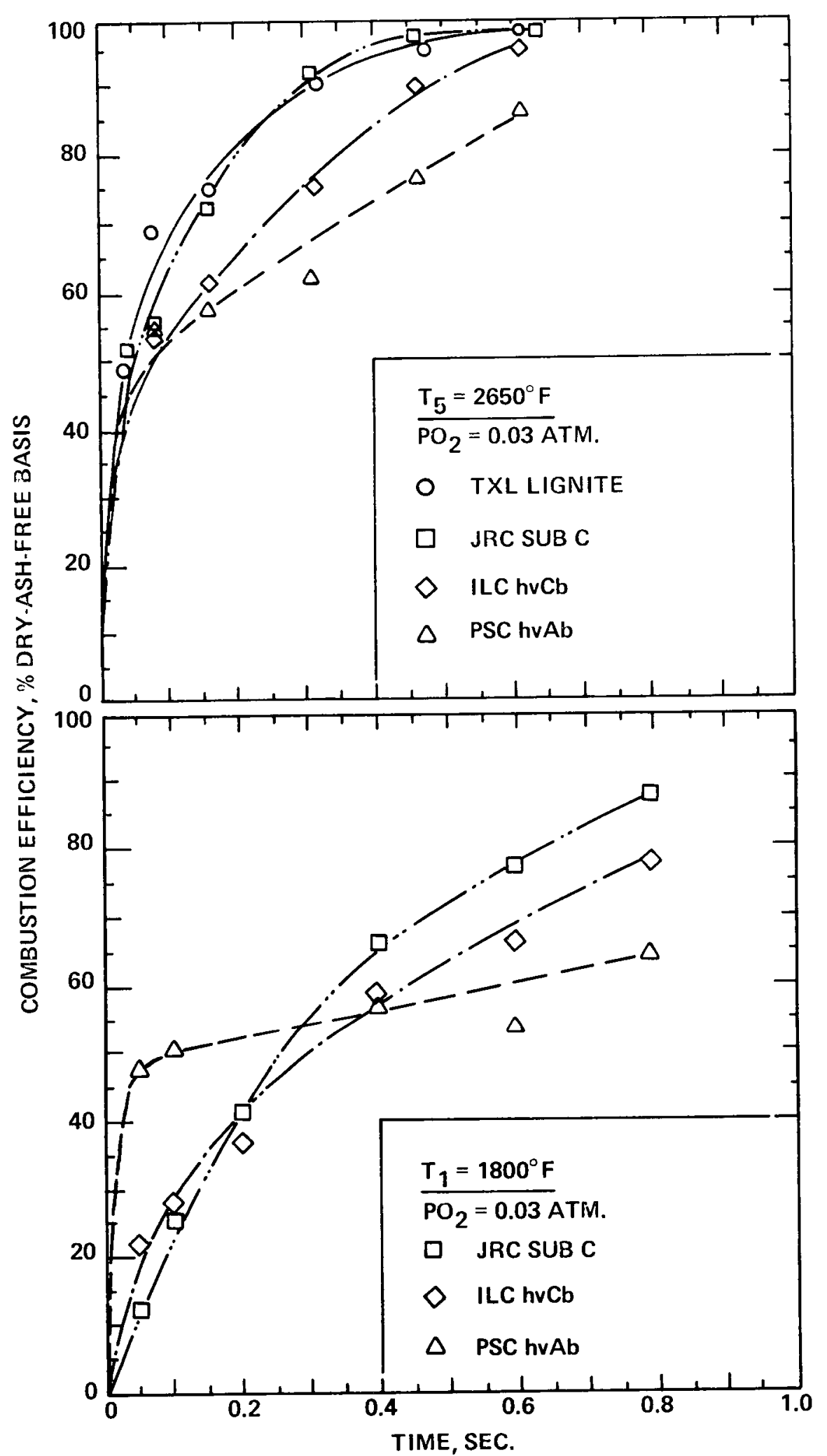

FIGURE 4-5 EFFECT OF GAS TEMPERATURE ON DTFS COMBUSTION EFFICIENCIES OF $200 \times 400 \mathrm{MESH}$ COALS 
Combustion of Chars

Effect of Temperature. The $200 \times 400$ mesh PSC, ILC, and JRC chars were studied at three gas temperatures $\left(1800,2200\right.$, and $2650^{\circ} \mathrm{F}$ ) in the presence of oxygen partial pressure of 0.03 atmosphere in nitrogen balance. Results are given in Figure 4-6. Combustion efficiencies are plotted as a function of residence time. The plots show that: (1) at a given temperature, the combustion efficiency increases with increasing residence time; and (2) at a given time, the combustion efficiency increases with increasing temperature. The latter is pronounced. For example, at $0.6 \mathrm{sec}$. residence time the combustion efficiency of the PSC char increased from $30 \%$ to $72 \%$ as temperature increased from $1800^{\circ} \mathrm{F}$. to $2650^{\circ} \mathrm{F}$. Data reproducibility, examined with PSC and ILC chars, was found to be good as clearly shown in Figure 4-6.

Effect of Fuel Properties. In order to more clearly compare combustion efficiencies between chars prepared from coals of different ranks, the curves in Figure 4-6 are re-plotted in Figure 4-7. The combustion efficiency curve of the TXL char at $2650^{\circ} \mathrm{F}$ is added to the appropriate figure frame. Figure 4-7 shows that (1) at $1800^{\circ} \mathrm{F}$ the following reactivity trends emerge: $\eta_{\text {JRCC }}>\eta_{\text {ILCC }}>\eta_{\text {PSCC }}$; and (2) at 2200 and $2650^{\circ} \mathrm{F}$ the trend is $\eta_{\text {ILCC }}>\eta_{\text {JRCC }}>\eta_{\text {PSCC }}$. Texas lignite char was tested at $2650^{\circ} \mathrm{F}$ only; its combustion is slightly better than that of the Illinois char.

Results indicate that the chars from Texas lignite, I1linois No. 6, and Jacobs Ranch coals are relatively comparable in reactivity and are more reactive than the Pittsburgh No. 8 coal char. During coal analyses it was determined that the first three coals are non-agglomerating while the Pittsburgh No. 8 coal is agglomerating. It should also be noted that chars from the more reactive coals are relatively porous having BET surface areas in the $54-213 \mathrm{~m}^{2} / \mathrm{g}$ range (Table $4-4$ ) while the Pittsburgh No. 8 char is relatively non-porous having a BET surface area of $13 \mathrm{~m}^{2} / \mathrm{g}$. These physical differences are believed to be largely responsible for combustion reactivity differences. This will be elaborated on in a subsequent section (Surface Area- Reactivity Relationships).

The combustion efficiency data given in Figure 4-6 were used to calculate the kinetic parameters (apparent activation energy and frequency factor) for each char. Results are presented in the "Kinetic Parameters" Section given later in the text. 


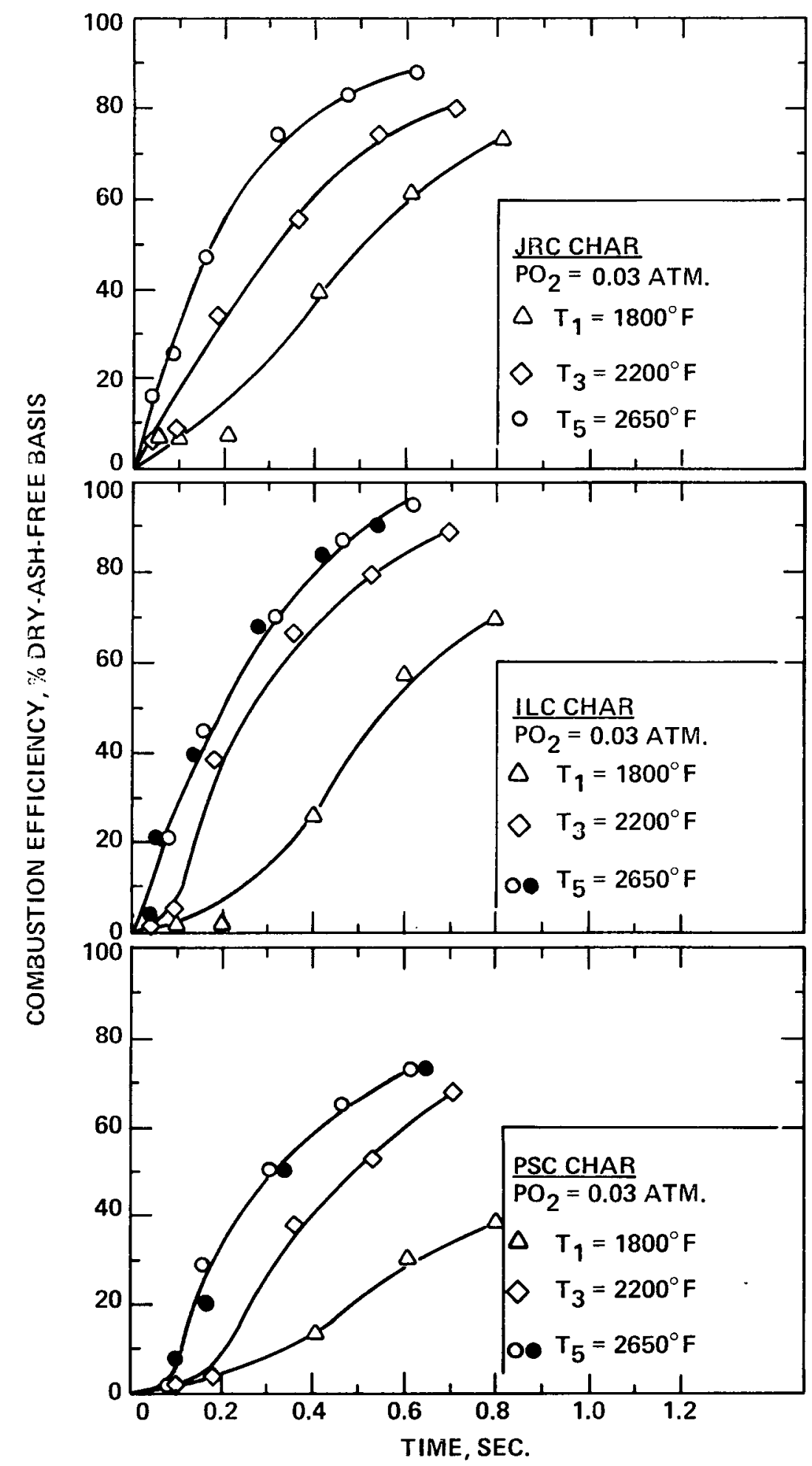

FIGURE 4-6 EFFECT OF GAS TEMPERATURE ON DTFS COMBUSTION EFFICIENCIES OF VARIOUS 200×400 MESH CHARS 


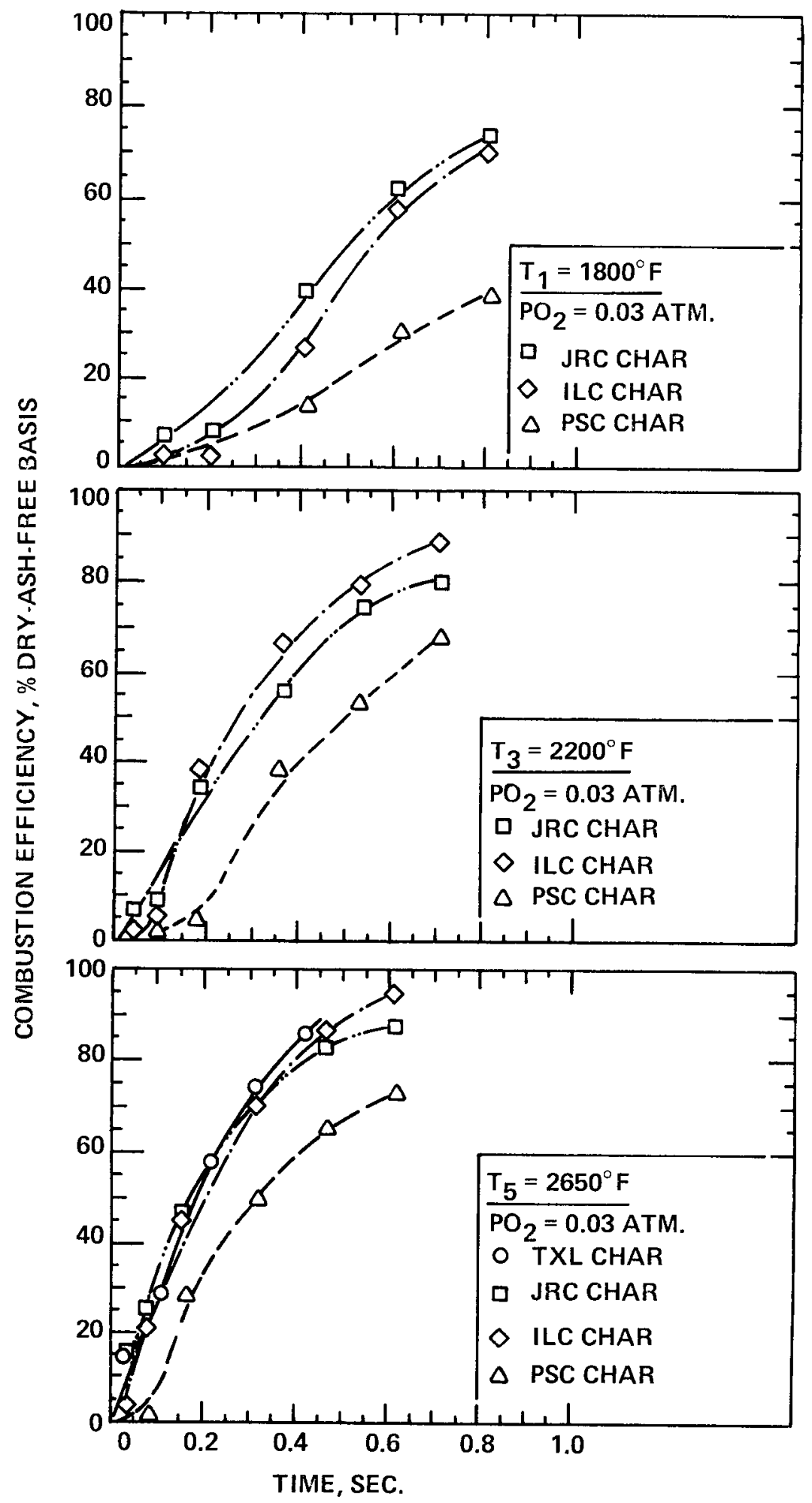

FIGURE 4-7 EFFECT OF FUEL TYPE ON DTFS COMBUSTION EFFICIENCES OF VARIOUS 200×400 MESH CHARS AT THREE GAS TEMPERATURES 
Effect of Oxygen Partial Pressure $\left(\mathrm{P}_{0}\right)$. The $200 \times 400$ mesh PSC char was also studied in the presence of oxygen partial pressures of 0.01 and 0.05 atmospheres at $2650^{\circ} \mathrm{F}$. Results, Figure 4-8, show that oxygen partial pressure has a significant effect on the combustion efficiency of PSC char. For example, at $0.6 \mathrm{sec}$. the combustion efficiency is 31,72 , and $97 \%$, respectively, for oxygen partial pressure of $0.01,0.03$, and 0.05 atmosphere.

Data in Figure 4-8 were used to calculate the char reaction order with respect to oxygen partial pressure. Results are presented in the following section.

Kinetic Parameters. All the kinetic parameters were determined as specified in Section 3. The mechanism mode (shrinking core versus constant diameter) was explored experimentally. This was done by determining the particle size distributions of the feed and partially reacted chars. Mean weight particle size results (Table 4-8) clearly show that combustion could be assumed to take place by a shrinking core mechanism. Therefore, q (rate of removal of carbon per unit external surface area) was calculated on the basis of this assumption.

Table 4-8

PARTICLE SIZE CHANGES DURING DTFS CHAR COMBUSTION AT $2650^{\circ} \mathrm{F}$ GAS TEMPERATURE

\begin{tabular}{ccccc} 
Reaction Zone & \multicolumn{5}{c}{ MEAN PARTICLE SIZE, $\bar{X}, \mu \mathrm{m}$} \\
Length, Inches & TXL Char & JRC Char & ILC Char & PSC Char \\
\hline $0^{1}$ & 51 & 51 & 55 & 53 \\
8 & 26 & 28 & 27 & 33 \\
12 & -- & -- & -- & -- \\
16 & 23 & 22 & 24 & 26
\end{tabular}

Note: $\quad$ 1. Feed char $(200 \times 400$ Mesh $)$

The values of surface reaction rate coefficients $\left(K_{S}\right)$ obtained by Eq. (3-7) for each char are given in Table 4-9. These $K_{S}$ values were used in conjunction with their corresponding temperatures (Eq. (3-8)) to derive the Arrhenius plots given 


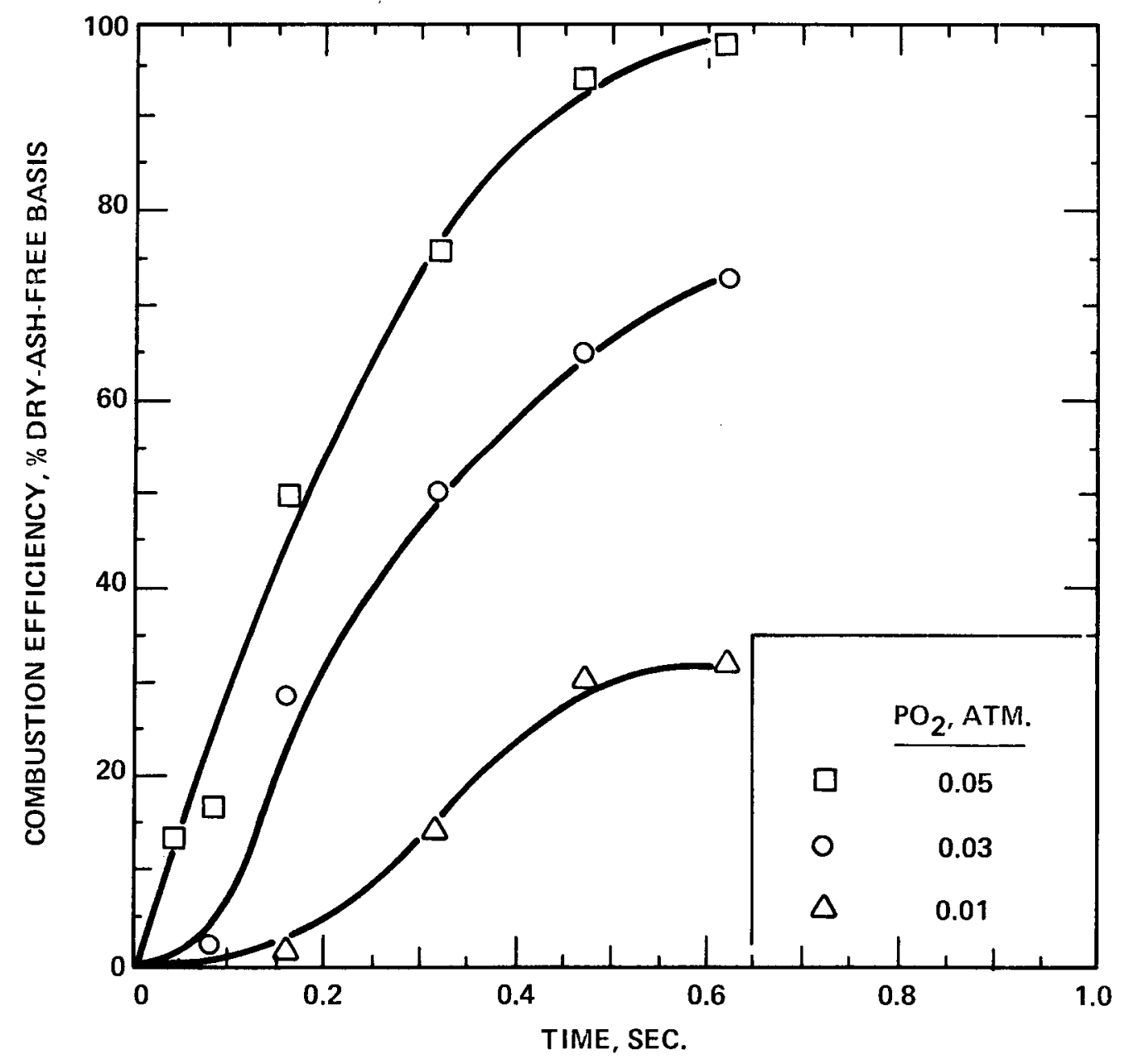

FIGURE 4-8 EFFECT OF OXYGEN PARTIAL PRESSURE ON DTFS COMBUSTION EFFICIENCY OF 200×400 MESH PSC CHAR AT $2650^{\circ} \mathrm{F}$ GAS TEMPERATURE 
Table 4-9

KINETIC DATA FROM COMBUSTION OF $200 \times 400$ MESH CHARS IN 0.03 OXYGEN ATMOSPHERE AND $1800-2650^{\circ} \mathrm{F}$ TEMPERATURE RANGE

\begin{tabular}{|c|c|c|c|c|c|c|}
\hline Char-Type & $\underset{{ }^{\circ} \mathrm{K}}{\text { Temp. }}$ & $\mathrm{gm} / \mathrm{cm}^{2}-\mathrm{ses}_{\mathrm{K}}^{\mathrm{K}} \cdot \mathrm{atm}$ & $\begin{array}{c}\mathrm{E} \\
\mathrm{cal} / \mathrm{mole}\end{array}$ & $\mathrm{gm} / \mathrm{cm}^{2}-\mathrm{sec}$ & atm & $Y$ \\
\hline$J R C$ & $\begin{array}{l}1227 \\
1257 \\
1259 \\
1258 \\
1409 \\
1449 \\
1481 \\
1492 \\
1567 \\
1594 \\
1636 \\
1679 \\
1713 \\
1726\end{array}$ & $\begin{array}{l}.01770 \\
.04484 \\
.07871 \\
.08981 \\
.11110 \\
.12362 \\
.20348 \\
.19479 \\
.20310 \\
.17227 \\
.26113 \\
.48106 \\
.52590 \\
.39209\end{array}$ & 19970 & 145 & & -0.92 \\
\hline ILC & $\begin{array}{l}1257 \\
1259 \\
1258 \\
1409 \\
1449 \\
1481 \\
1492 \\
1594 \\
1636 \\
1679 \\
1713 \\
1726\end{array}$ & $\begin{array}{l}.02647 \\
.06783 \\
.07989 \\
.13971 \\
.30481 \\
.25937 \\
.27593 \\
.14412 \\
.24737 \\
.29370 \\
.40921 \\
.39119\end{array}$ & 17150 & 60 & & -0.86 \\
\hline PSC & $\begin{array}{l}1257 \\
1259 \\
1258 \\
1449 \\
1481 \\
1492 \\
1636 \\
1679 \\
1713 \\
1726\end{array}$ & $\begin{array}{l}.01123 \\
.02118 \\
.02357 \\
.06005 \\
.07655 \\
.10114 \\
.09267 \\
.12611 \\
.17151 \\
.17698\end{array}$ & 20360 & 66 & : & -0.96 \\
\hline
\end{tabular}

$K_{S}=$ Surface Reaction Rate Coefficient

$E^{S}=$ Apparent Activation Energy

$A=$ Frequency Factor

$Y=$ Correlation Coefficient of $\ln \mathrm{K}_{\mathrm{S}}$ vs. $1 / T$ 
in Figure 4-9. The apparent activation energy ( $E$ ) and frequency factor ( $A$ ) values were determined from the slopes and intercepts of the least squares fits of $1 n K_{S}$ vs. $1 / T$ plots.

The apparent activation energies obtained from this study are 20360, 17150, and $19970 \mathrm{cal} / \mathrm{mole}$ for PSC, ILC, and JRC chars, respectively. The corresponding frequency factors are 66,60 , and $145 \mathrm{~g} \mathrm{~cm}^{-2} \mathrm{sec}^{-1} \mathrm{~atm}^{-1}$. The plots in Figure 4-9 yielded correlation coefficients of -0.86 to -0.96 . A11 the kinetic data from this study are presented in Table 4-9.

To compare the relative reactivites of these chars from a theoretical standpoint, their $E$ and $A$ values are plugged in the Arrhenius Equation and the surface reaction rate coefficients $\left(K_{S}\right)$ are calculated as a function of temperature alone. Results are plotted in Figure 4-10. These curves show that while the ILC char is slightly more reactive than the JRC char at lower temperatures, the converse is true at higher temperatures. The PSC char is much less reactive than JRC and ILC chars, and is generally comparable in reactivity to a fuel representing the values of $E(35700 \mathrm{cal} / \mathrm{mole})$ and $A\left(8710 \mathrm{~g} \mathrm{~cm}^{-2} \mathrm{sec}^{-1} \mathrm{~atm}^{-1}\right)$ obtained by Field and co-workers at BCURA ( $\underline{9}$ ) from the least squares fits on 1 in $K_{S} v s .1 / T$ data found in the literature. At $2650^{\circ} \mathrm{F}$, the $K_{S}$ values of JRC, ILC, BCURA, and PSC chars are $0.430,0.405,0.264,0.175 \mathrm{~g} \mathrm{~cm}^{-2} \mathrm{sec}^{-1} \mathrm{~atm}^{-1}$, respectively.

The combustion kinetic reaction order with respect to oxygen concentration was evaluated for PSC char. The method used by Knight and Sergeant ( $\underline{8}$ ) was also used here. That is

$$
K_{S}^{\prime}=K^{\prime}\left[0_{2}\right]^{n}
$$

where $K_{S}^{\prime}$ is the reaction rate coefficient, $\mathrm{g} \mathrm{cm}^{-2} \mathrm{sec}^{-1}, K^{\prime}$ is a constant, and $n$ is the reaction order. Manipulating Eq. (4-1) yields

$$
\ln K_{S}^{\prime}=\ln K^{\prime}+n \ln \left[0_{2}\right]
$$

A plot of $\ln \mathrm{K}_{S}^{\prime}$ vs. In $\left[\mathrm{O}_{2}\right]$ gives a straight line whose slope is equal to $\mathrm{n}$.

This method was used as shown in Table 4-10 and Figure 4-11. The value of $n$ in this figure is equal to 0.92 , which is very close to first order. Computer printouts of char combustion data are given in Appendix $C$. 

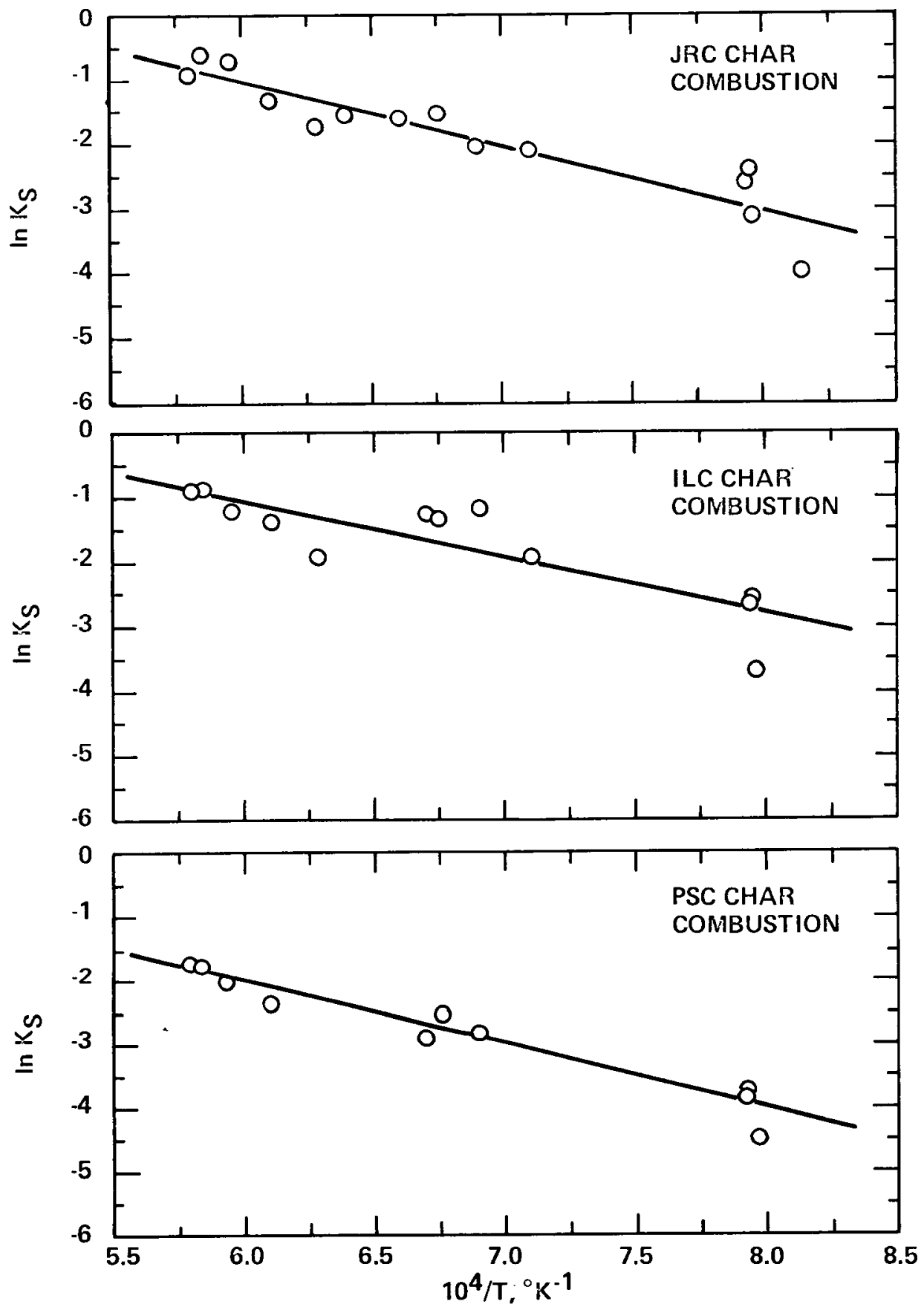

FIGURE 4-9 ARRHENIUS PLOTS FOR $200 \times 400 \mathrm{MESH}$ CHAR COMBUSTION IN THE DTFS 


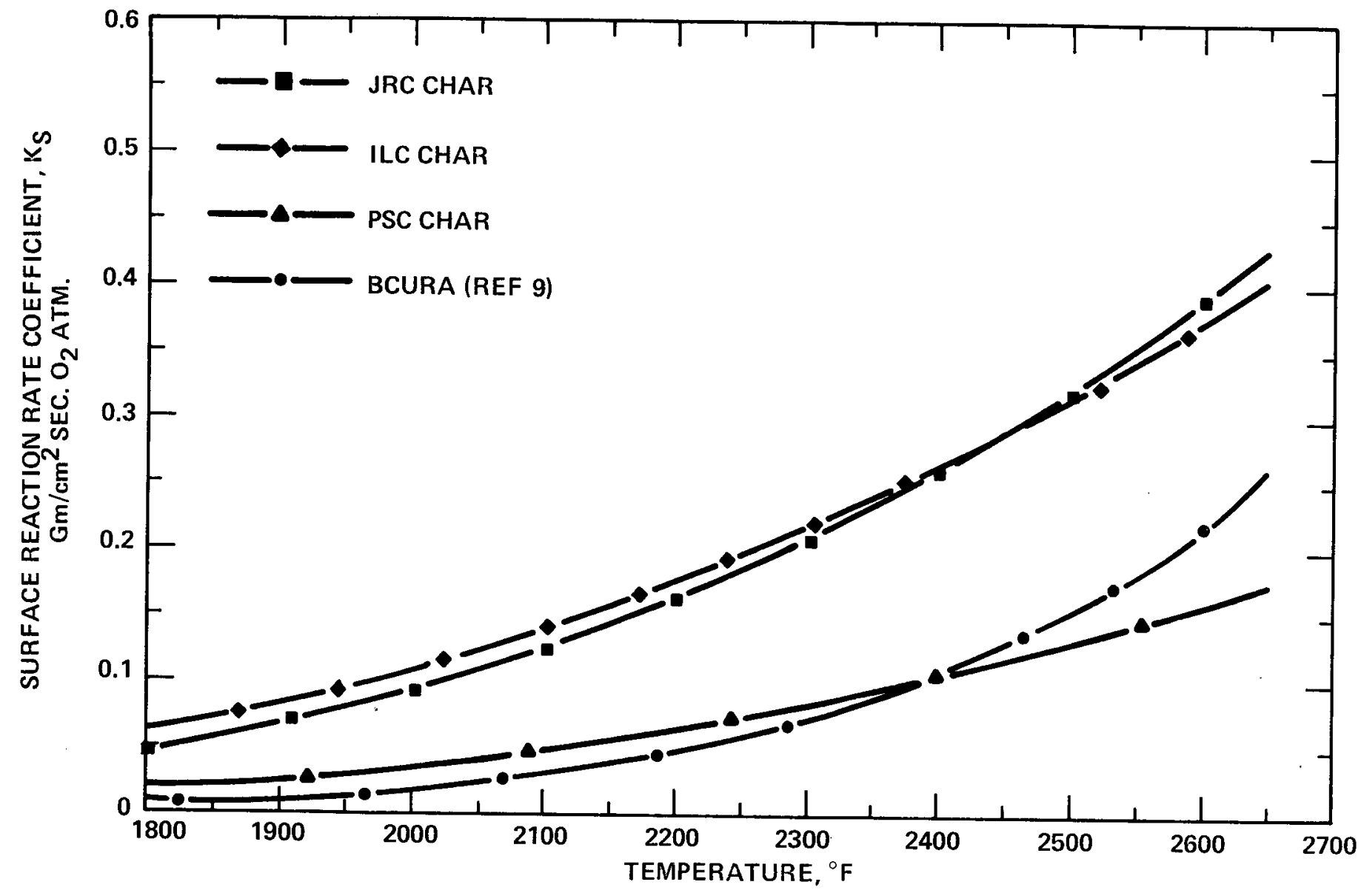

FIGURE 4-10 VARIATION OF COMBUSTION SURFACE REACTION RATE COEFFICIENT WITH TEMPERATURE FOR VARIOUS CHARS IN THE DTFS 


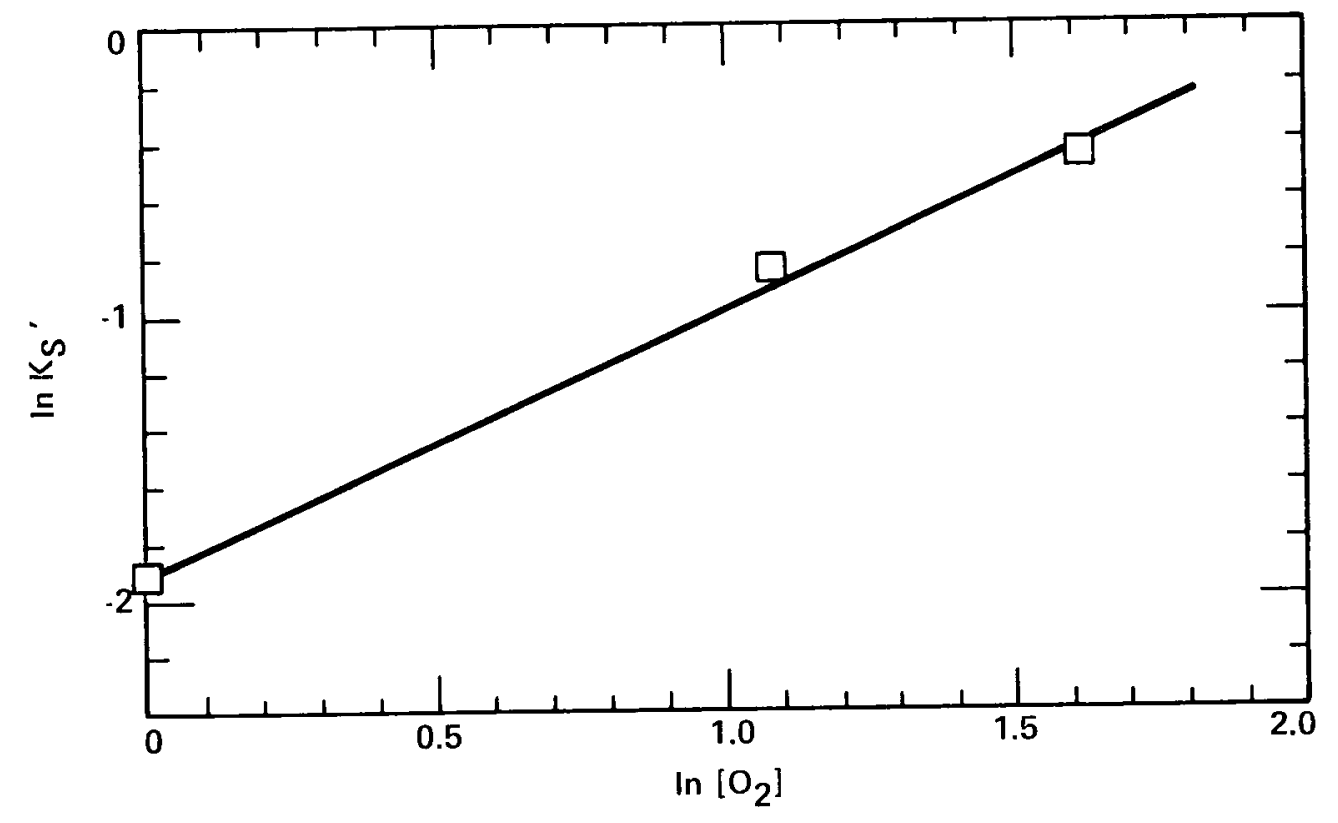

FIGURE 4-11 VARIATION OF In $\mathrm{K}_{S}{ }^{\prime}$ WITH In [O $\mathrm{O}_{2}$ ] FOR $200 \times 400$ MESH PSC CHAR COMBUSTION IN THE DTFS AT $2650^{\circ} \mathrm{F}$ GAS TEMPERATURE 
Table 4-10

DATA FOR EVALUATING COMBUSTION REACTION ORDER

OF $200 \times 400$ MESH PSC CHAR

\begin{tabular}{|c|c|c|c|}
\hline $\begin{array}{l}{\left[0_{2}\right]} \\
\% \\
\end{array}$ & $\ln \left[0_{2}\right]$ & $\begin{array}{l}\mathrm{K}_{\mathrm{S}}^{\prime}=\overline{\mathrm{K}}_{\mathrm{S}_{2}} \times\left[\mathrm{O}_{2}\right]_{1}^{*} \\
\mathrm{~g} \mathrm{~cm}^{-2} \mathrm{sec}^{*}\end{array}$ & $\ln \mathrm{K}_{\mathrm{S}}^{\prime}$ \\
\hline 1 & 0.00 & 0.1462 & -1.922 \\
\hline 3 & -1.10 & 0.4254 & -0.855 \\
\hline 5 & -1.61 & 0.6369 & -0.451 \\
\hline
\end{tabular}

$\bar{*}_{\bar{K}_{S}}$ are averages of $K_{S}$ values found at each oxygen partial pressure.

Gasification of Chars

Effect of Temperature. The gasification of $200 \times 400$ mesh JRC char was studied at $2000,2200,2450$, and $2650^{\circ} \mathrm{F}$ in the presence of carbon dioxide partial pressure of 0.30 atmosphere in nitrogen balance. The TXL char was studied at 2000 , 2200 , and $2650^{\circ} \mathrm{F}$. The ILC and PSC chars were sluggish at $2000^{\circ} \mathrm{F}$. Therefore, they were studied only at 2200,2450 , and $2650^{\circ} \mathrm{F}$. Results on gasification efficiency vs. time are plotted in Figures $4-12 a$ and $4-12 b$. These plots show that:

(1) at a given temperature, the gasification efficiency increases with increasing residence time; and (2) at a given time, the gasification efficiency increases with increasing temperature. The latter effect is pronounced. For example, at $0.6 \mathrm{sec}$. residence time the gasification efficiency of PSC char increased from less than $1 \%$ to $6 \%$ as temperature increased from $2200^{\circ} \mathrm{F}$ to $2650^{\circ} \mathrm{F}$.

Effect of Fuel Properties. To show more clearly the comparison in gasification efficiencies between chars prepared from coals of different ranks, the curves in Figures $4-12 a$ and $4-12 b$ are re-plotted in Figure 4-13. The gasification efficiency ( $n$ ) trend in all cases is $\eta_{\text {TXLC }}>\eta_{\text {JRCC }}>\eta_{\text {ILCC }}>\eta_{P S C C}$. However, it is important to note that the gasification efficiencies of PSC and ILC chars are much lower than those of TXL and JRC chars. For example, at $2650^{\circ} \mathrm{F}$ after 0.6 second of reaction time, $\eta_{T X L C}=76 \%, \eta_{J R C C}=66 \%, \eta_{I L C C}=19 \%$, and $\eta_{P S C C}=6 \%$. These differences are believed to be largely attributable to differences in internal surface area and follow similar trends to the BET areas (Table 4-4) which were $213,97,54$, and $13 \mathrm{~m}^{2} / \mathrm{g}$ for the TXL, JRC, ILC, and PSC chars, respectively. 


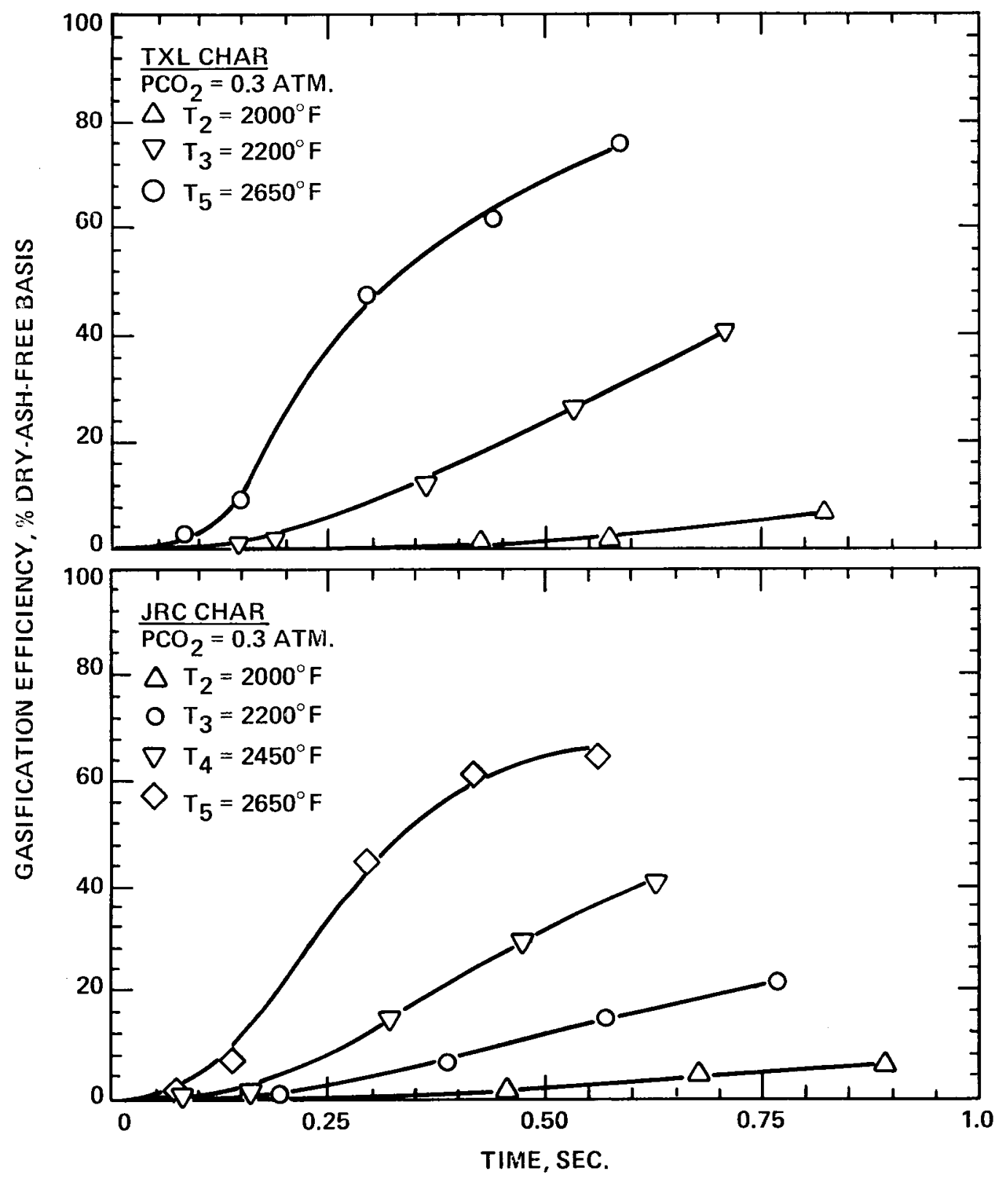

FIGURE 4-12a EFFECT OF GAS TEMPERATURE ON DTFS

GASIFICATION EFFICIENCIES OF TXL AND JRC

200×400 MESH CHARS 


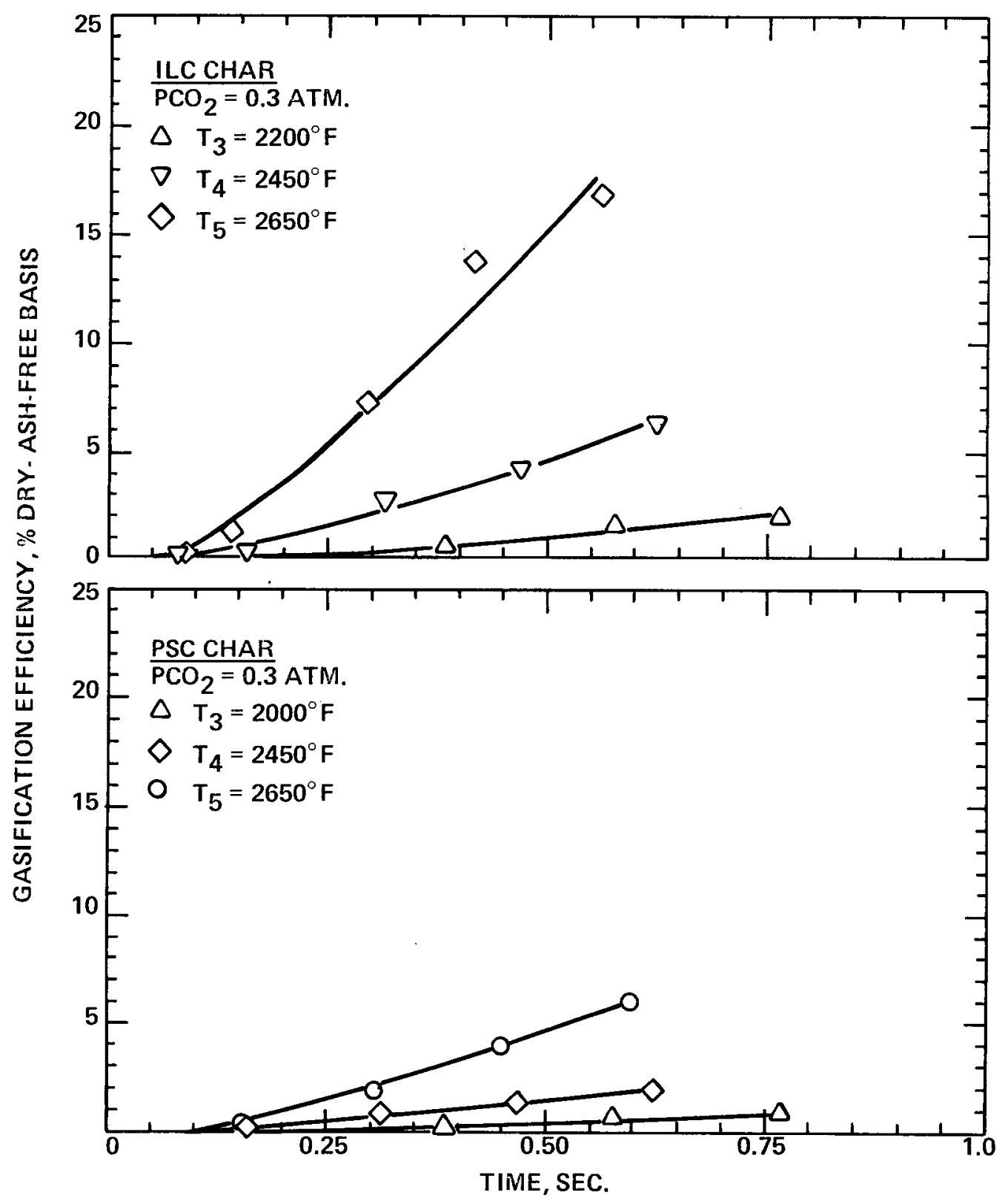

FIGURE 4-12b EFFECT OF GAS TEMPERATURE ON DTFS GASIFICATION EFFICIENCIES OF ILC AND PSC 200×400 MESH CHARS 


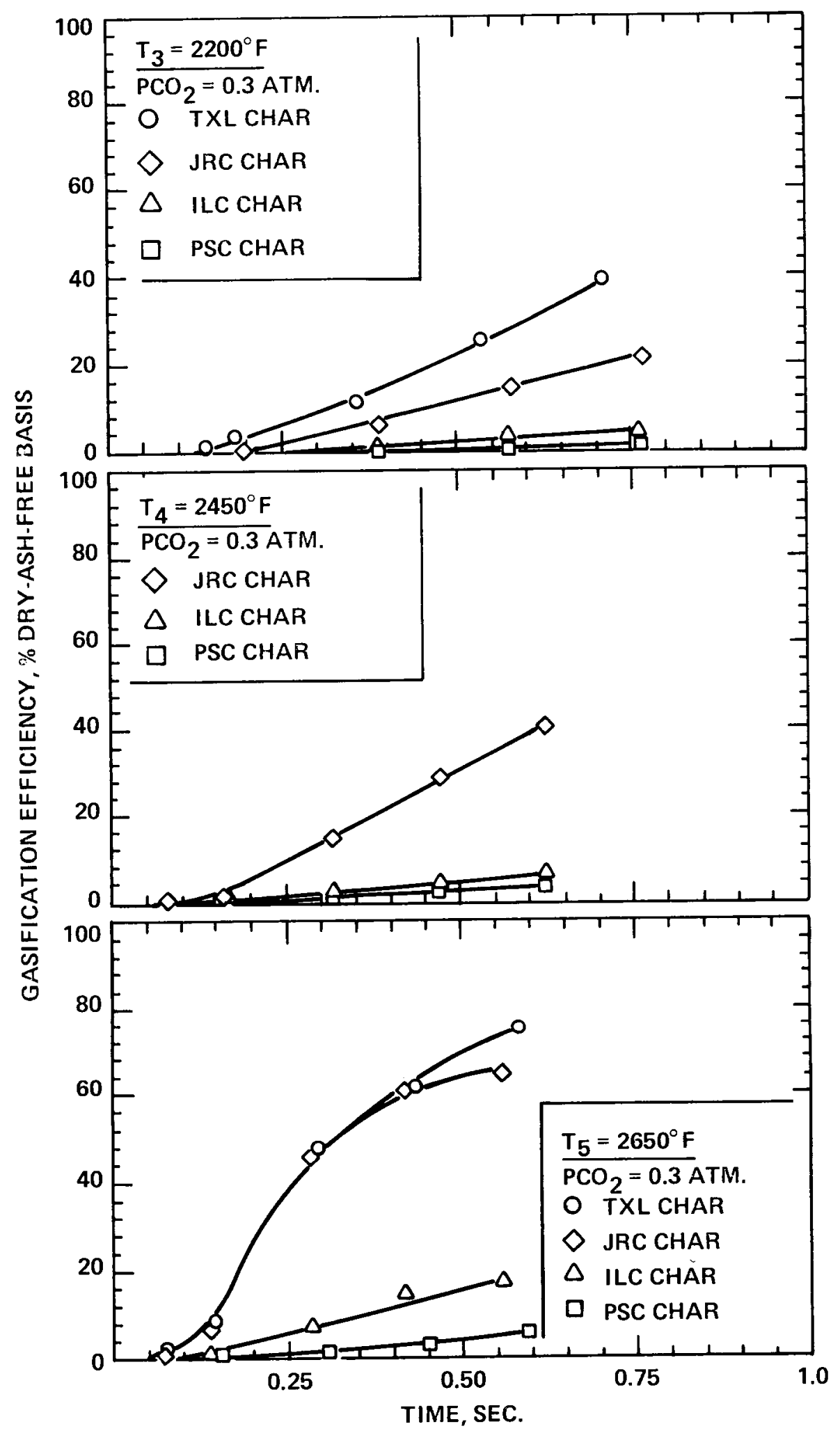

FIGURE 4-13 EFFECT OF FUEL TYPE ON DTFS GASIFICATION EFFICIENCIES OF VARIOUS $200 \times 400 \mathrm{MESH}$ CHARS AT THREE GAS TEMPERATURES 
The gasification efficiency data given in Figures $4-12 a$ and $4-12 b$ were used to calculate the kinetic parameters (apparent activation energy and frequency factor) for each char. Results are presented in the "Kinetic Parameters" Section presented later in the text.

Effect of Particle Size. Two size fractions, $200 \times 400$ mesh and -400 mesh obtained by grinding a portion of $200 \times 400$ mesh, were used to determine the effect of particle size on the gasification efficiencies of JRC, ILC, and PSC chars. A third size, -400 mesh obtained from size grading the whole char, was studied in the case of PSC char. Results, given in Figure 4-14, show that gasification efficiency is inversely proportional to particle size. For example, after 0.6 sec. reaction time, the gasification efficiencies are $66 \%$, and $96 \%$, respectively, for $200 \times 400$ mesh and -400 mesh JRC chars. The corresponding values for ILC and PSC chars are 20 and $30 \%$, and 6 and $16 \%$, respectively. It is interesting to note that the -400 mesh PSC char obtained from size grading the whole char is only marginally more reactive than the $200 \times 400$ mesh char.

These results are in agreement with TGA gasification reactivity results presented earlier in Figure 4-2. Grinding the $200 \times 400$ mesh chars to -400 mesh increases the available internal surface area for reactivity. The BET pore surface area results, Table 4-4, bear out this postulate. Knight and Sergeant also found from their thermo-gravimetric gasification studies in carbon dioxide of Australian coal chars that reactivity varied inversely with particle size for their low reactivity Lithgow coal char ( 8 ).

The particle size effects indicate that gasification is a surface rather than volumetric reaction. Further the fact that the -400 mesh cut (obtained by size grading) was only marginally more reactive than the $200 \times 400$ mesh cut indicates that the intrinsic reactivity of the fuel may be a function of not only particle size but also of other factors (such as the content and degree of dispersion of mineral impurities).

Effect of Carbon Dioxide Partial Pressure $\left({ }^{P} \mathrm{CO}_{2}\right)$. The $200 \times 400$ mesh PSC char was also studied in the presence of carbon dioxide partial pressures of 0.15 and 0.60 atmospheres at $2650^{\circ} \mathrm{F}$. Results, Figure $4-15$, show that carbon dioxide partial pressure has a significant effect on the gasification efficiency of PSC char. For example, at $0.6 \mathrm{sec}$. the gasification efficiency is 3,6 , and $9 \%$, respectively, for carbon dioxide partial pressures of $0.15,0.30$, and 0.60 atmosphere. 


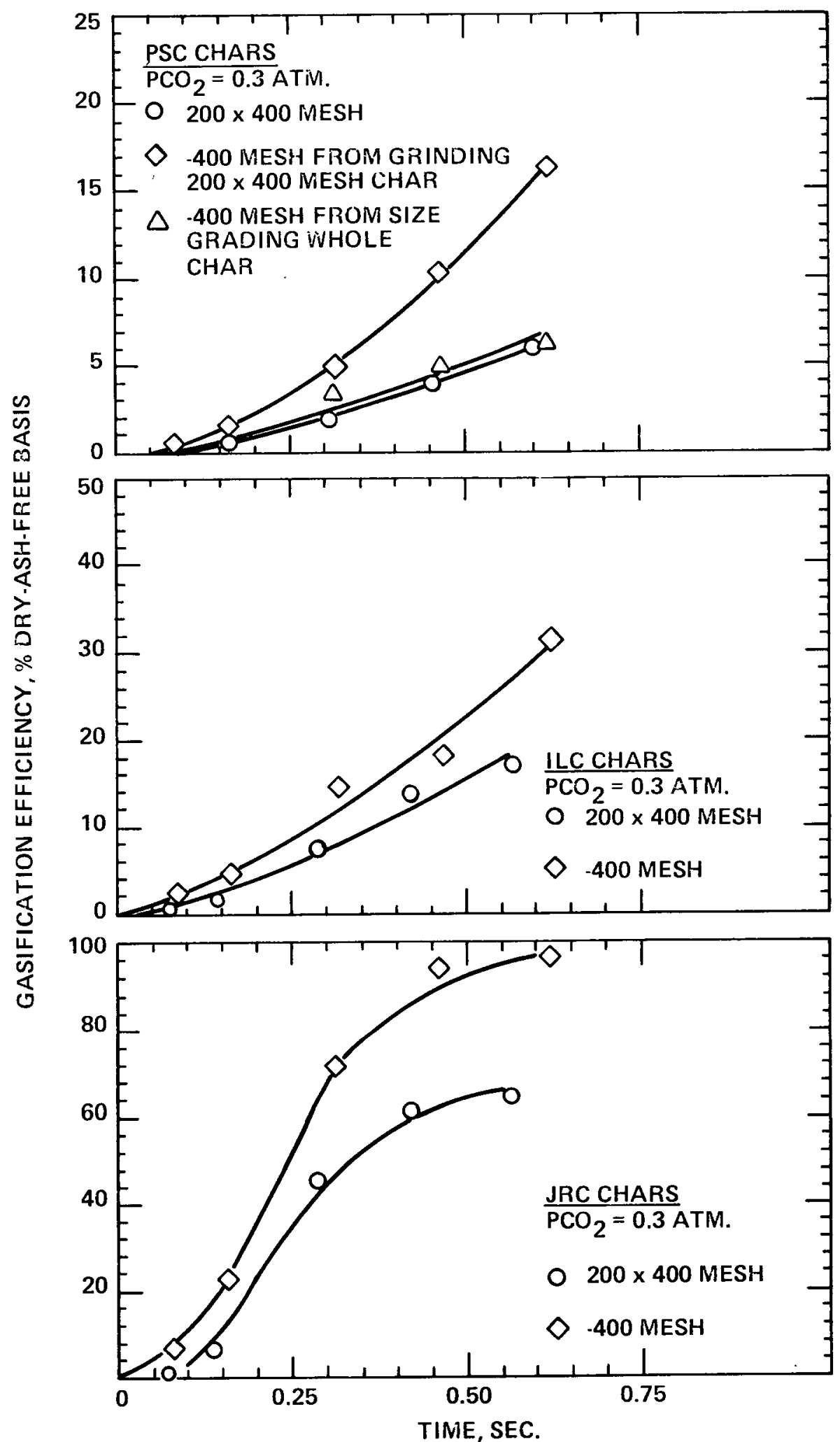

FIGURE 4-14 EFFECT OF PARTICLE SIZE ON DTFS GASIFICATION EFFICIENCIES OF VARIOUS CHARS AT $2650^{\circ} \mathrm{F}$ GAS TEIMPERATURE 


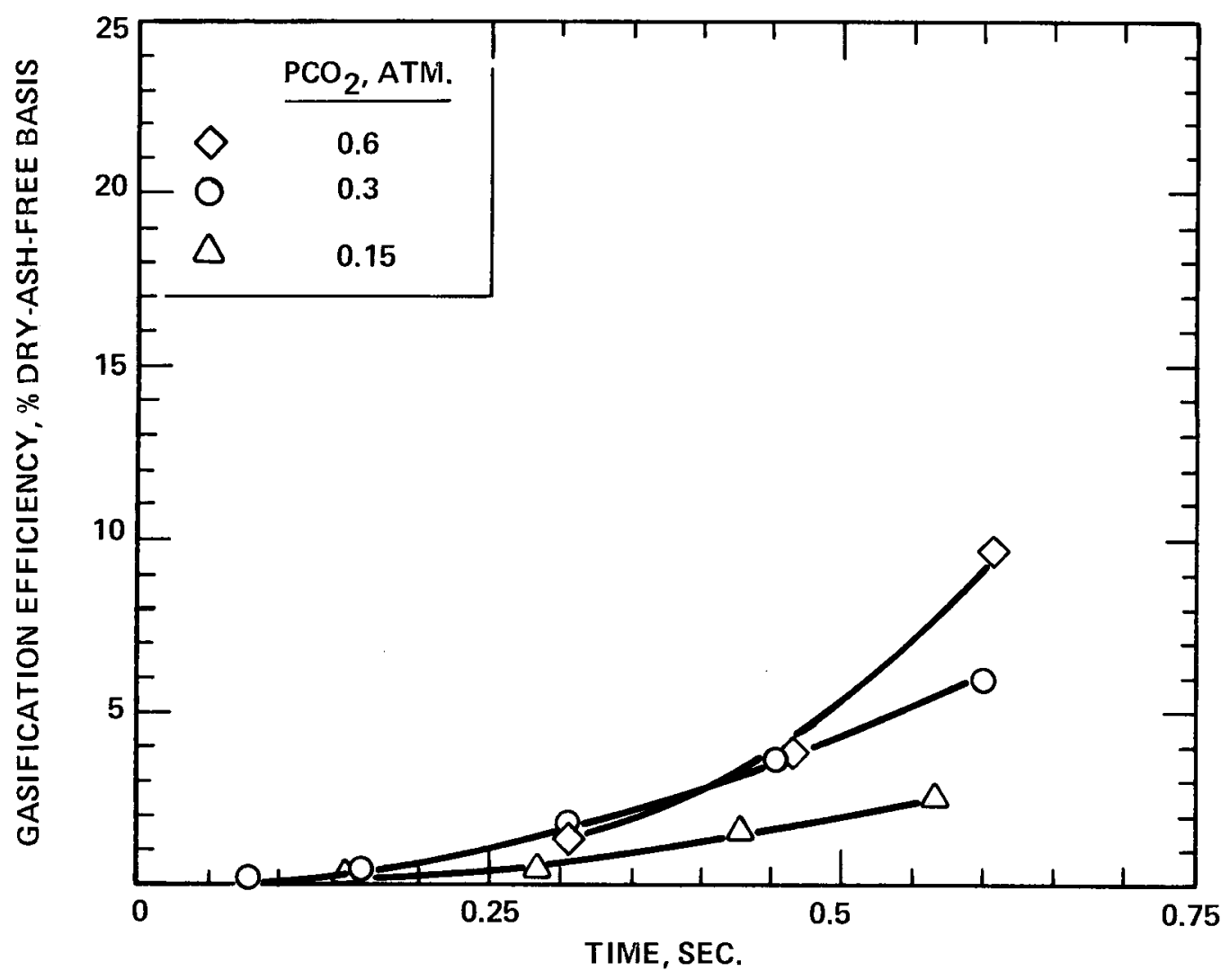

FIGURE 4-15 EFFECT OF CARBOIN DIOXIDE PARTIAL PRESSURE ON DTFS GASIFICATION EFFICIENCY OF $200 \times 400 \mathrm{MESH}$

PSC CHAR AT $2650^{\circ} \mathrm{F}$ GAS TEMPERATURE 
Data in Figure 4-15 were used to calculate the char reaction order with respect to carbon dioxide partial pressure. Results from this calculation are presented in the "Kinetic Parameters" Section given later in the text.

Effect of Gasification Medium. The $200 \times 400$ mesh PSC and JRC chars were also studied in the presence of 0.30 atmosphere of steam in nitrogen balance. Results for JRC char are given in Figure 4-16. The effect of temperature on the gasification efficiency of this char in steam is also discernible. For example, at $0.45 \mathrm{sec}$, the gasification efficiencies are $2 \%$ and $22 \%$ for gas temperatures of $2200^{\circ} \mathrm{F}$ and $2650^{\circ} \mathrm{F}$ respectively. The PSC char reactivity in steam was too low to measure in the $2000-2650^{\circ} \mathrm{F}$ temperature range.

JRC gasification efficiencies in steam and carbon dioxide are compared in Figure 4-17. It is found that gasification is more efficient in carbon dioxide than it is in steam. For example, at $2650^{\circ} \mathrm{F}$ and $0.45 \mathrm{sec}$. the gasification efficiencies are 61 and $22 \%$, for $\mathrm{C}-\mathrm{CO}_{2}$ and $\mathrm{C}-\mathrm{H}_{2} \mathrm{O}$ reactions, respectively. The disparity in reactivites between $\mathrm{C}-\mathrm{CO}_{2}$ and $\mathrm{C}-\mathrm{H}_{2} \mathrm{O}$ reactions will be discussed in the section on "Kinetic Parameters" given below.

Carbon Mass Balance During Char Gasification in $\mathrm{CO}_{2-}$ - A few char samples were collected at the sixteen-inch reaction zone of the DTFS throughout this gasification testing phase. During these particular runs, the experiments were carefully timed and the chars collected in the filter housing were weighed and their proximate and ultimate ( $\mathrm{C}, \mathrm{H}$, and $\mathrm{N}$ only) analyses were determined. Since the char feed rates were known accurately, it was possible to calculate carbon mass balance. The $200 \times 400$ mesh ILC char was also used to run two repeat carbon mass balance tests using a fixed probe fitted unto the bottom of the DTFS. Results are presented in Table 4-11. The ash tracer method was used to determine char gasification efficiency in all cases. These values were compared with the corresponding gasification efficiencies obtained by $\mathrm{CO}$ concentrations in the effluent gas streams. These results are plotted in Figure 4-18.

Results in Table 4-11 show carbon balance closure values in the $85-103 \%$ range. It is important to note that $56 \%$ of these values are within the $90-100 \%$ range. Data depicted in Figure 4-18 also show the agreement between the char gasification efficiencies determined by ash tracer and co concentration methods. Data are almost evenly distributed on both sides of the perfect-agreement line, indicating that neither of these two methods shows a particular bias. Nevertheless, the ash 


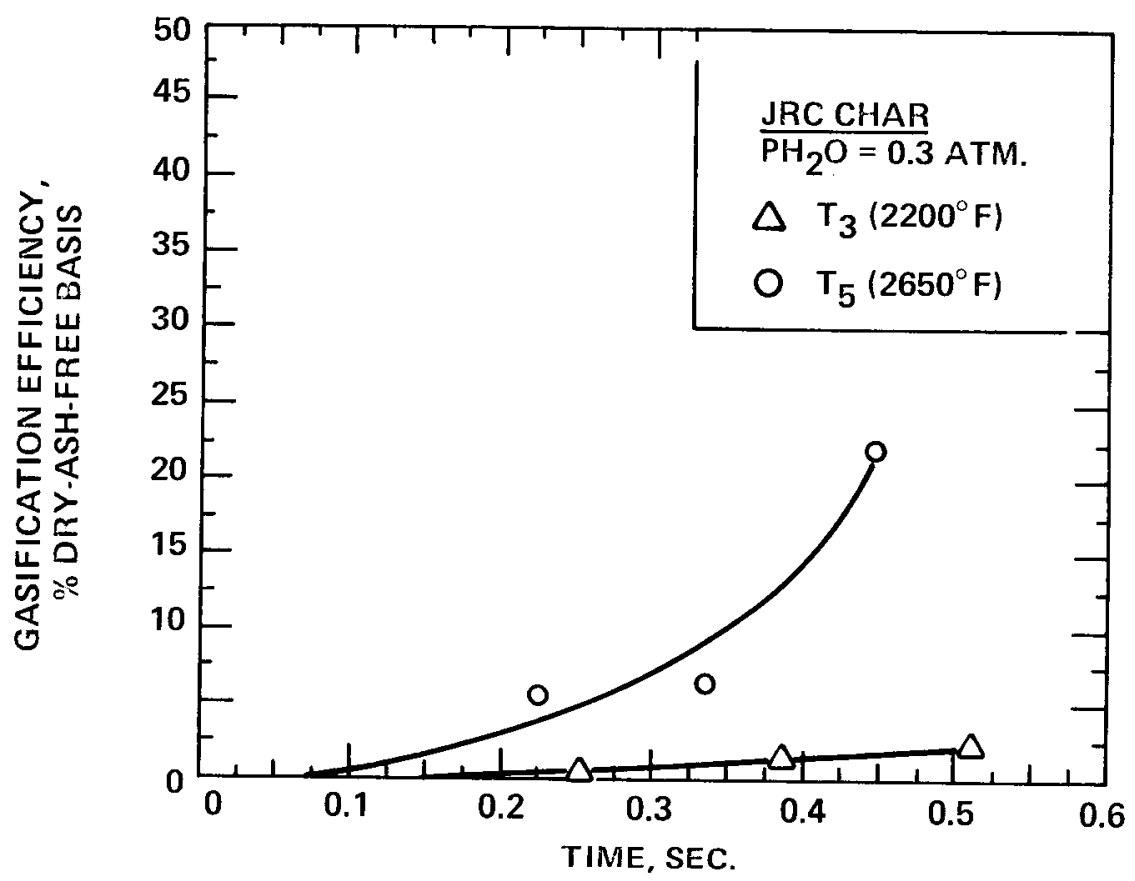

FIGURE 4-16 EFFECT OF GAS TEMPERATURE ON DTFS GASIFICATION EFFICIENCY OF 200×400 MESH JRC CHAR IN STEAM

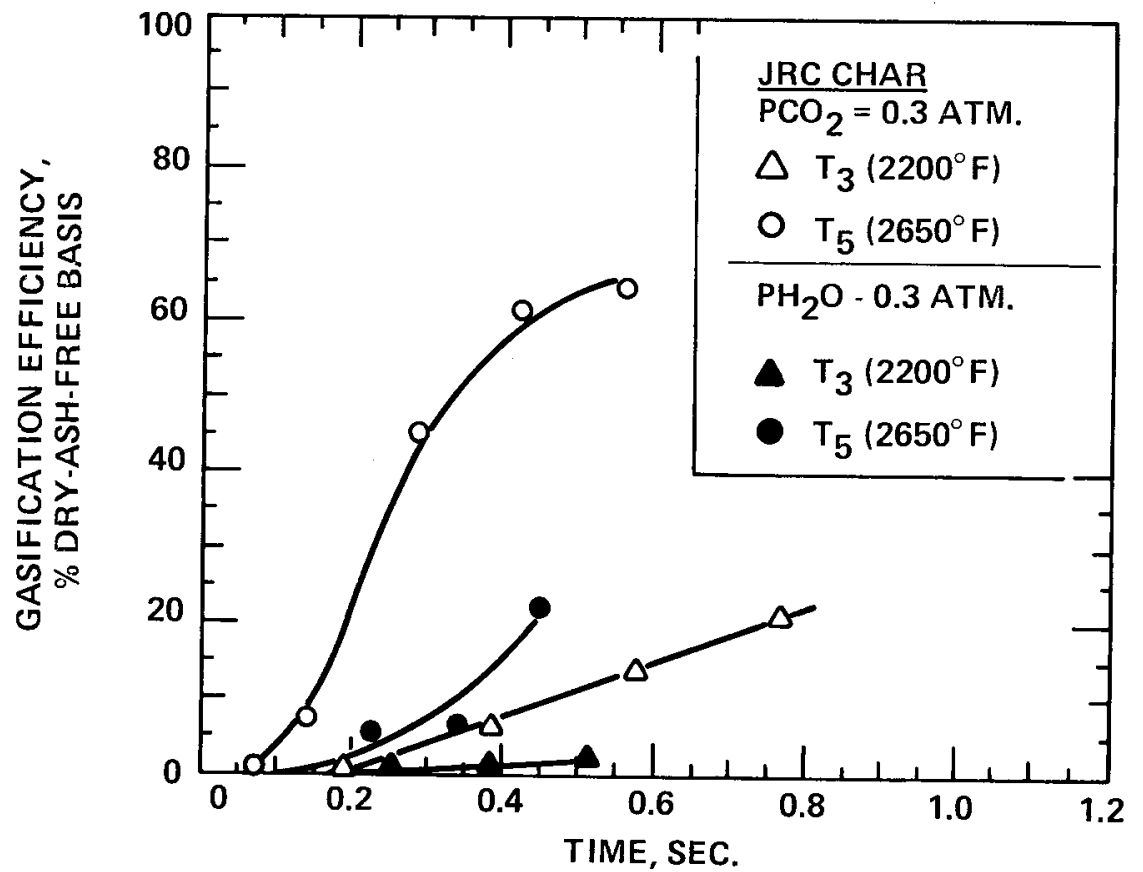

FIGURE 4-17 EFFECT OF TEMPERATURE AND REACTION MEDIUM ON DTFS GASIFICATION EFFICIENCY OF 200×400 MESH JRC CHAR 
Table 4-11

CARBON MASS BALANCE FOR GASIFICATION OF CHARS IN 0.3 CARBON DIOXIDE ATMOSPHERE AT VARIOUS GAS TEMPERATURES

\begin{tabular}{|c|c|c|c|c|c|c|c|c|}
\hline \multirow[b]{2}{*}{ CHAR-TYPE } & \multirow[b]{2}{*}{ TEST NO. } & \multirow[b]{2}{*}{$\begin{array}{l}\text { TEMPERATURE } \\
{ }^{\circ} \mathrm{F}\end{array}$} & \multicolumn{4}{|c|}{ CARBON MASS BALANCE } & \multicolumn{2}{|c|}{$\begin{array}{c}\text { GASIFICATION } \\
\text { EFFICIENCY } \\
\%, \text { DAF }\end{array}$} \\
\hline & & & $\begin{array}{c}\text { CARBON IN } \\
\text { FEED CHAR, } \\
\mathrm{g} / \mathrm{min}\end{array}$ & $\begin{array}{l}\text { CARBON IN } \\
\mathrm{CO}, \mathrm{g} / \mathrm{min}\end{array}$ & $\begin{array}{c}\text { CARBON IN } \\
\text { REACTED CHAR, } \\
\mathrm{g} / \mathrm{min}\end{array}$ & $\begin{array}{c}\text { CARBON } \\
\text { CLOSURE } \\
\text { (PCT) }\end{array}$ & $\begin{array}{l}\text { CO } \\
\text { CONC. }\end{array}$ & $\begin{array}{l}\text { ASH } \\
\text { TRACER }\end{array}$ \\
\hline $\begin{array}{l}\text { PSC } \\
\text { Chars }\end{array}$ & $\begin{array}{l}\text { PSCC-VI -3 } \\
\text { PSCC-VI-4 } \\
\text { PSCC-VI -5 } \\
\text { PSCC-VI-5 }\end{array}$ & $\begin{array}{l}2200 \\
2450 \\
2650 \\
2650\end{array}$ & $\begin{array}{l}0.06568 \\
0.07143 \\
0.06896 \\
0.05644\end{array}$ & $\begin{array}{l}0.00051 \\
0.00137 \\
0.00406 \\
0.00906\end{array}$ & $\begin{array}{l}0.06514 \\
0.06119 \\
0.05949 \\
0.04879\end{array}$ & $\begin{array}{r}100.0 \\
87.6 \\
92.1 \\
102.5\end{array}$ & $\begin{array}{r}0.8 \\
1.9 \\
5.9 \\
16.1\end{array}$ & $\begin{array}{r}0.1 \\
5.4 \\
11.7 \\
11.7\end{array}$ \\
\hline $\begin{array}{l}\text { JRC } \\
\text { Chars }\end{array}$ & $\begin{array}{l}\text { JRCC - I I - 3 } \\
\text { JRCC-I I -4 } \\
\text { JRCC-I I - } 5^{2}\end{array}$ & $\begin{array}{l}2200 \\
2450 \\
2650\end{array}$ & $\begin{array}{l}0.06690 \\
0.00690 \\
0.04617\end{array}$ & $\begin{array}{l}0.01445 \\
0.02697 \\
0.04462\end{array}$ & $\begin{array}{l}0.04860 \\
0.02969 \\
0.00155\end{array}$ & $\begin{array}{r}94.2 \\
84.7 \\
100.0\end{array}$ & $\begin{array}{l}21.6 \\
40.3 \\
96.6\end{array}$ & $\begin{array}{l}16.5 \\
44.3 \\
94.7\end{array}$ \\
\hline $\begin{array}{l}\text { ILC } \\
\text { Chars }\end{array}$ & $\begin{array}{l}\text { ILCC-I I - } \\
\text { ILCC-I I -4 } \\
\text { ILCC-I I-5 } \\
\text { ILCC-II-52 } \\
\text { ILCC-FP-13 } \\
\text { ILCC-FP-2 }\end{array}$ & $\begin{array}{l}2200 \\
2450 \\
2650 \\
2650 \\
2650 \\
2650\end{array}$ & $\begin{array}{l}0.04999 \\
0.04922 \\
0.05075 \\
0.05700 \\
0.05092 \\
0.05016\end{array}$ & $\begin{array}{l}0.00096 \\
0.00309 \\
0.00856 \\
0.01738 \\
0.00985 \\
0.00963\end{array}$ & $\begin{array}{l}0.04404 \\
0.04214 \\
0.03812 \\
0.03188 \\
0.03306 \\
0.03388\end{array}$ & $\begin{array}{l}90.0 \\
92.0 \\
92.0 \\
86.4 \\
84.3 \\
86.7\end{array}$ & $\begin{array}{l}1.9 \\
6.3 \\
16.9 \\
30.5 \\
19.3 \\
19.2\end{array}$ & $\begin{array}{r}1.5 \\
8.5 \\
15.2 \\
32.1 \\
19.3 \\
22.5\end{array}$ \\
\hline $\begin{array}{l}\text { TXL } \\
\text { Chars }\end{array}$ & $\begin{array}{l}\text { TXLC-II-2 } \\
\text { TXLC-II -3 } \\
\text { TXLC-II-3R }\end{array}$ & $\begin{array}{l}2000 \\
2200 \\
2200\end{array}$ & $\begin{array}{l}0.03962 \\
0.03714 \\
0.03714\end{array}$ & $\begin{array}{l}0.00090 \\
0.00337 \\
0.01458\end{array}$ & $\begin{array}{l}0.03673 \\
0.03234 \\
0.02371\end{array}$ & $\begin{array}{r}95.0 \\
96.2 \\
103.1\end{array}$ & $\begin{array}{r}2.3 \\
9.1 \\
39.2\end{array}$ & $\begin{array}{r}7.5 \\
5.1 \\
25.5\end{array}$ \\
\hline
\end{tabular}

1. Most of the chars were collected at 16-inch DTFS reaction zone; other chars were collected through a fixed probe fitted unto the bottom of the DTFS. Feed chars were $200 \times 400$ mesh unless otherwise specified.

2. These -400 mesh chars were obtained from grinding portions of $200 \times 400$ mesh chars.

3. Data obtained with a fixed probe.

4. Carbon Closure $=100$ [Carbon in Products/Carbon in Feed Char.] 


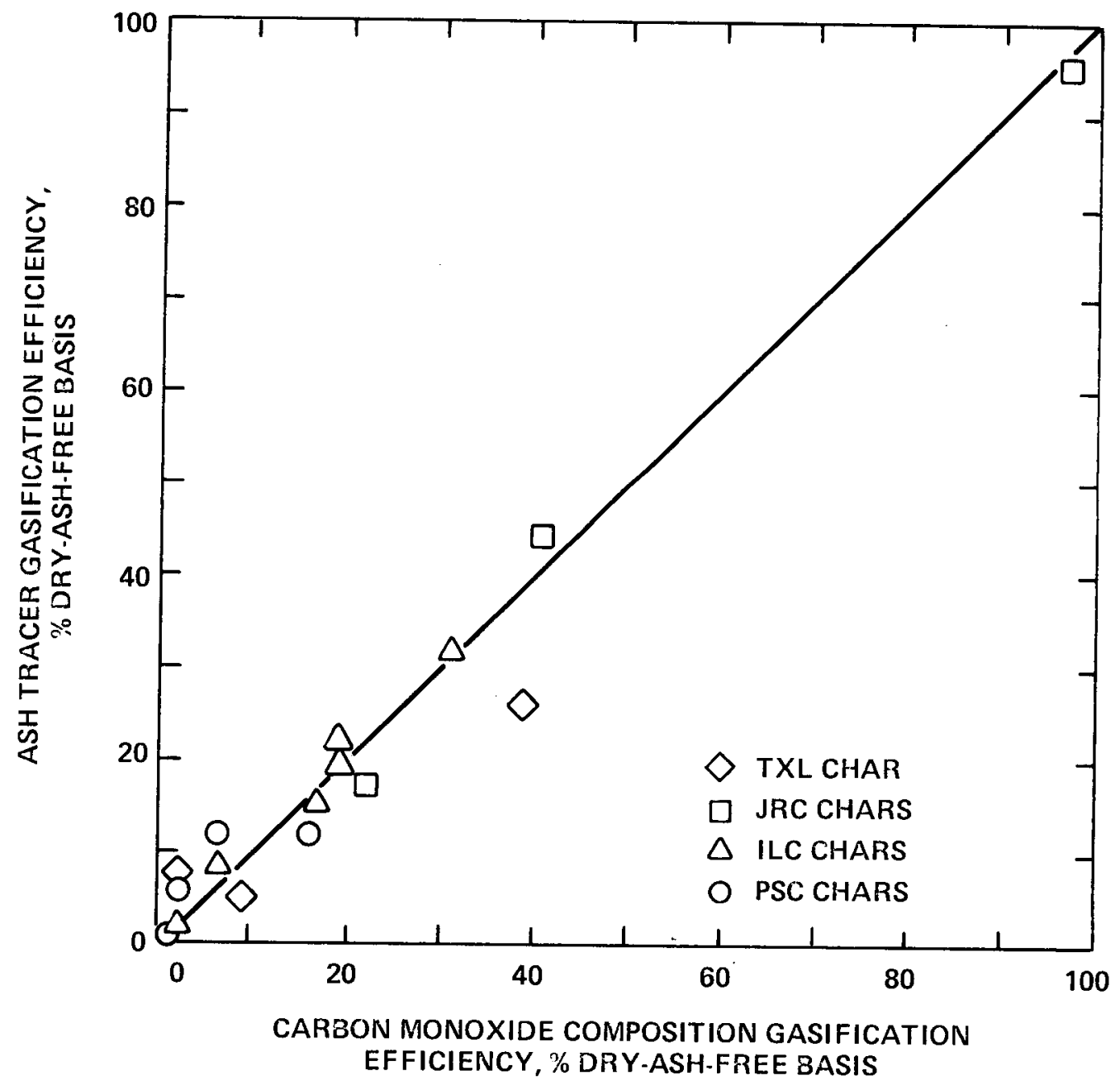

FIGURE 4-18 COMPARISON BETWEEN ASH TRACER AND CO COMPOSITION METHODS FOR CALCULATING GASIFICATION EFFICIENCIES OF VARIOUS CHARS 
tracer method was found to be prone to yielding spurious (sometimes negative) results in the low gasification efficiency range. In addition, because it is possible to measure low concentrations of CO (down to $50 \mathrm{ppm}$ ) this gas tracer technique should provide better resolution, particularly at low carbon conversion efficiencies.

Kinetic Parameters. All the kinetic parameters were determined as specified in Section 3. Data in Table 4-12 show that char gasification could be assumed to proceed by a shrinking core mechanism. Therefore, q (rate of removal of carbon per unit external surface area) was determined on the basis of this assumption.

Table 4-12

PARTICLE SIZE CHANGES DURING DTFS CHAR GASIFICATION AT $2650^{\circ} \mathrm{F}$ GAS TEMPERATURE

\begin{tabular}{ccccc}
$\begin{array}{l}\text { Reaction Zone } \\
\text { Length, Inches }\end{array}$ & TXL Char & JRC Char & ILC Char & PSC Char \\
\hline $0^{1}$ & 51 & 51 & 55 & 53 \\
8 & 28 & 22 & -- & -- \\
12 & -- & -- & -- & 50 \\
16 & 30 & 22 & 43 & 43
\end{tabular}

Note: $\quad$ 1. Feed char $(200 \times 400$ Mesh $)$

The values of surface reaction rate coefficients $\left(K_{S}\right)$ obtained by $E q$. (3-7) for each char are presented in Table 4-13. These values were used in conjunction with their corresponding temperatures (Eq. (3-8)) to derive the Arrhenius plots given in Figures 4-19a and 4-19b. The apparent activation energy (E) and frequency factor $(A)$ values were determined from the slopes and intercepts of the least squares fits of $\ln \mathrm{K}_{\mathrm{S}}$ vs. $\mathrm{l} / \mathrm{T}$ plots.

The apparent activation energies obtained from this study are: 53700,56360 , 42470, and 39490 cal/mole for PSC, ILC, JRC, and TXL char, respectively. The corresponding frequency factors are: $1390,12950,1040$, and $660 \mathrm{~g} \mathrm{~cm}^{-2} \mathrm{sec}^{-1} \mathrm{~atm}^{-1}$. 
Table 4-13

KINETIC DATA FROM GASIFICATION OF $200 \times 400$ MESH CHARS IN 0.3 CARBON DIOXIDE ATMOSPHERE AND $2000-2650^{\circ} \mathrm{F}$ TEMPERATURE RANGE

\begin{tabular}{|c|c|c|c|c|c|}
\hline Char-Type & $\underset{{ }^{\circ}}{\operatorname{Temp}}$ & $\mathrm{gm} / \mathrm{cm}^{2}{ }^{\mathrm{K}_{\mathrm{S}}} \mathrm{s}_{\mathrm{c}} \cdot \mathrm{atm}$ & $\begin{array}{c}E \\
\mathrm{cal} / \mathrm{mole}\end{array}$ & $\mathrm{gm} / \mathrm{cm}^{2}-\mathrm{sec} \cdot \mathrm{atm}$ & $\gamma$ \\
\hline TXL & $\begin{array}{l}1365 \\
1485 \\
1498 \\
1488 \\
1721 \\
1724 \\
1720\end{array}$ & $\begin{array}{l}.00019 \\
.00098 \\
.00152 \\
.00188 \\
.00578 \\
.00548 \\
.00582\end{array}$ & 39490. & 660 & -0.96 \\
\hline$J R C$ & $\begin{array}{l}1294 \\
1332 \\
1365 \\
1485 \\
1498 \\
1488 \\
1613 \\
1616 \\
1617 \\
1697 \\
1721 \\
1724 \\
1720\end{array}$ & $\begin{array}{l}.00004 \\
.00020 \\
.00016 \\
.00046 \\
.00071 \\
.00087 \\
.00148 \\
.00196 \\
.00219 \\
.00137 \\
.00579 \\
.00577 \\
.00461\end{array}$ & 42470 & 1040 & -0.96 \\
\hline ILC & $\begin{array}{l}1485 \\
1498 \\
1488 \\
1613 \\
1616 \\
1617 \\
1721 \\
1724 \\
1720\end{array}$ & $\begin{array}{l}.00006 \\
.00008 \\
.00008 \\
.00026 \\
.00028 \\
.00031 \\
.00081 \\
.00106 \\
.00099\end{array}$ & 56360 & 12950 & -0.99 \\
\hline PSC & $\begin{array}{l}1485 \\
1498 \\
1488 \\
1574 \\
1602 \\
1613 \\
1616 \\
1617 \\
1721 \\
1724 \\
1720\end{array}$ & $\begin{array}{l}.00001 \\
.00003 \\
.00003 \\
.00004 \\
.00004 \\
.00007 \\
.00007 \\
.00009 \\
.00016 \\
.00026 \\
.00030\end{array}$ & 53700 & 1390 & -0.94 \\
\hline
\end{tabular}

$K_{S}=$ Surface Reaction Rate Coefficient

$E^{S}=$ Apparent Activation Energy

$A=$ Frequency Factor

$Y=$ Correlation Coefficient of $1 n K_{S}$ vs. $T / T$ 

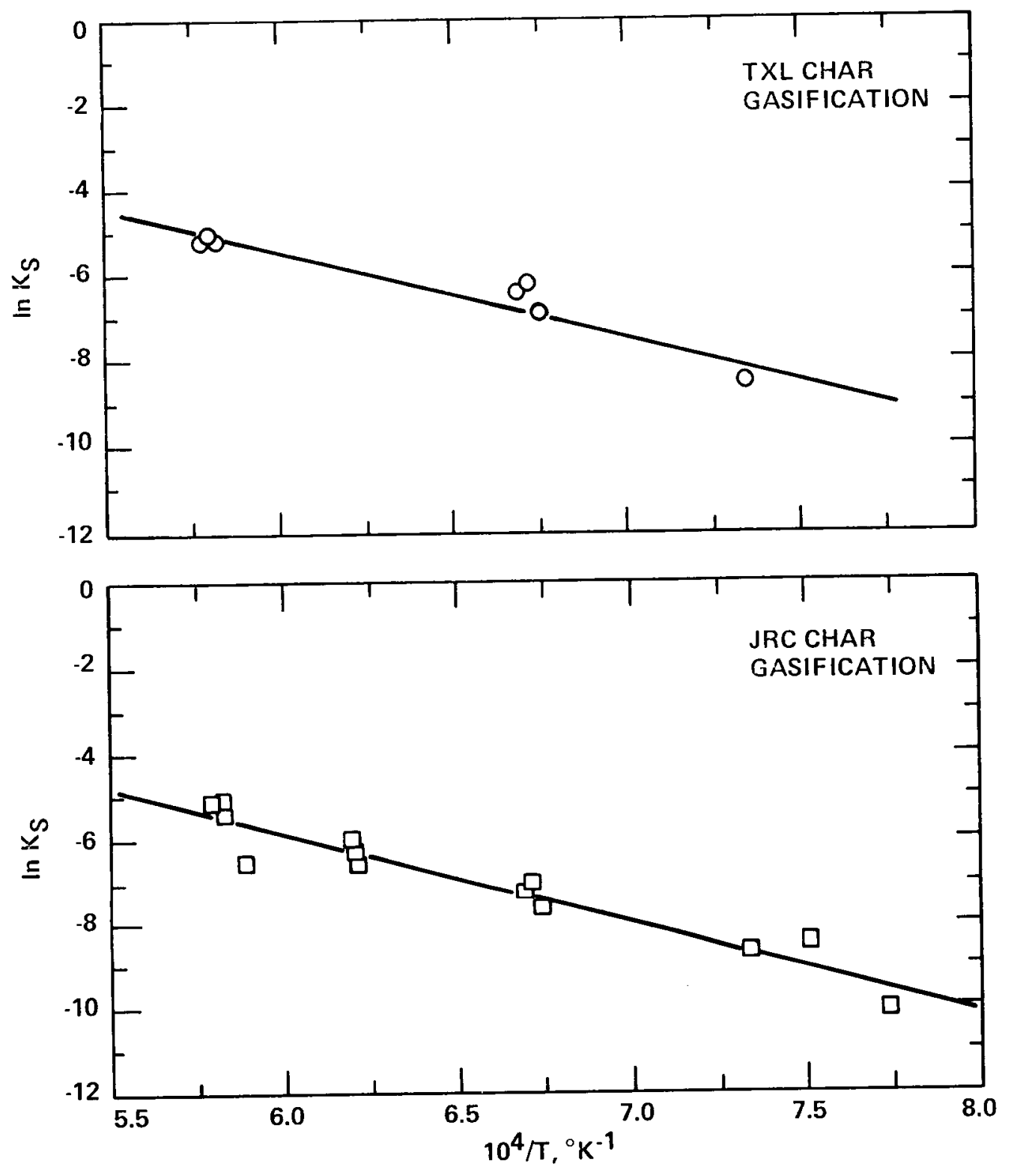

FIGURE 4-19a ARRHENIUS PLOTS FOR GASIFICATION OF

200x400 MESH TXL AND JRC CHARS IN THE DTFS 

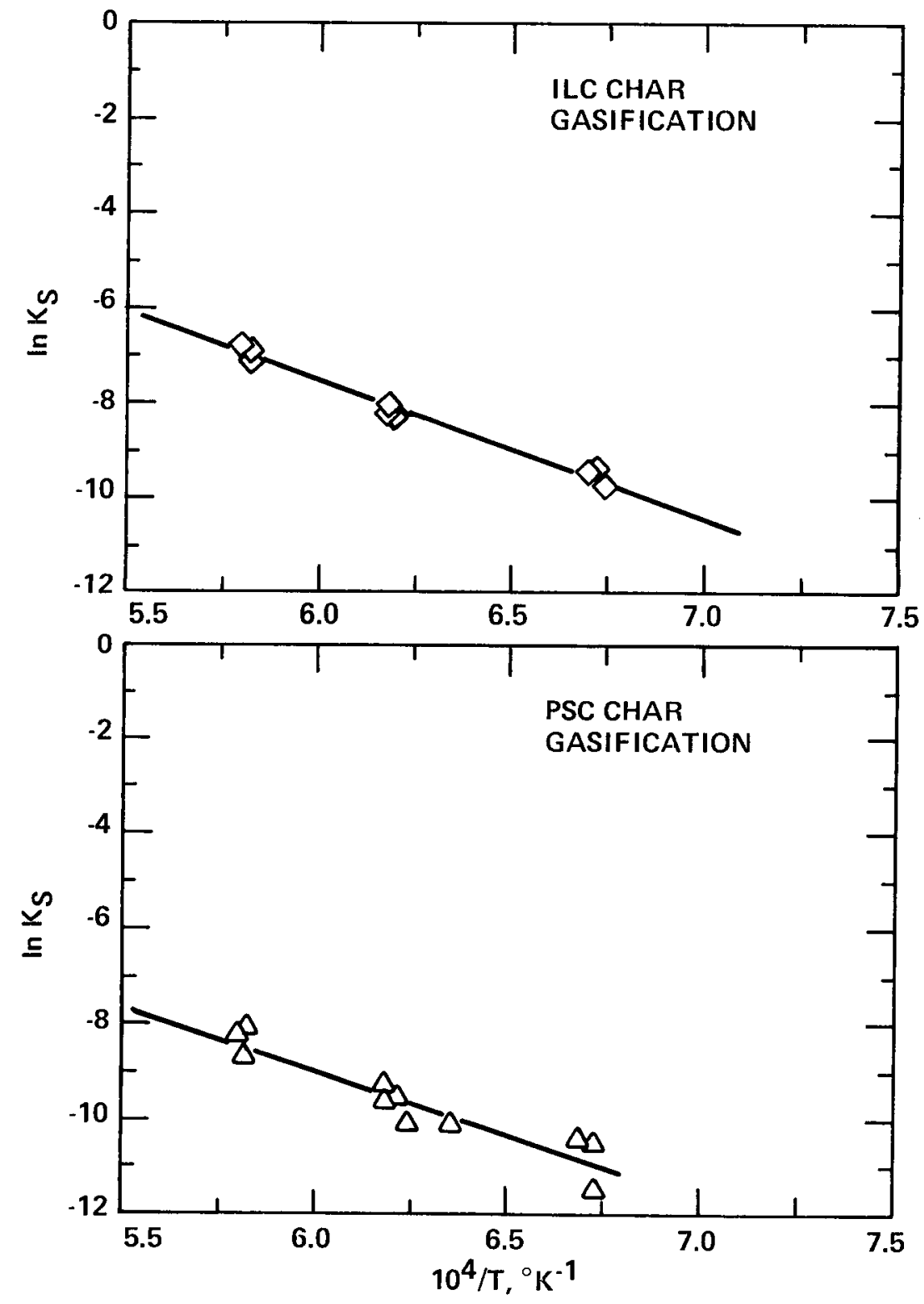

FIGURE 4-19b ARRHENIUS PLOTS FOR GASIFICATION OF 200×400 MESH ILC AND PSC CHARS IN THE DTFS 
The plots in Figures $4-19 a$ and $4-19 b$ yielded correlation coefficients in the range of -0.94 to -0.99 . All the kinetic data from this study are given in Table 4-13.

Wen and Chuang ( $\underline{5}$ ) have used kinetic parameter values derived by Dobner ( 6 ) from the data obtained by Gray and Kimber in their laminar flow reactor using a commercial charcoal prepared from coal by steam activation (7). These values are 42 $\mathrm{kcal} / \mathrm{mole}$ for activation energy (E) and $247 \mathrm{~g} \mathrm{~cm}^{-2} \mathrm{sec}^{-1} \mathrm{~atm}^{-1}$ for frequency factor (A). The values of activation energy found by Knight and Sergeant ( 8 ) in their thermo-gravimetric gasification studies of four chars are in a rather narrow range of $219-233 \mathrm{~kJ} / \mathrm{mole}(52-56 \mathrm{kcal} / \mathrm{mole})$. Results obtained from the present study are quite clearly in the range of those found by these research teams ( $\underline{5}$, $\underline{6}, \underline{7}, \underline{8})$.

To classify the relative reactivities of the chars studied, from a theoretical standpoint, their $E$ and $A$ values are plugged into the Arrhenius Equation and the surface reaction rate coefficients $\left(K_{S}\right)$ are calculated as a function of temperature alone. Wen and Chuang's values are included for comparison. Results, Figure 4-20, show that TXL and JRC chars are much more reactive than ILC and PSC chars and that Wen and Chuang's char (WCC) is slightly more reactive than ILCC char. For example, at $2650^{\circ} \mathrm{F}$ the $K_{S}$ values of TXLC, JRCC, WCC, ILCC, and PSCC are $0.00663,0.00436,0.00125,0.000946$, and $0.000221 \mathrm{~g} \mathrm{~cm}^{-2} \mathrm{sec}^{-1} \mathrm{~atm}^{-1}$, respectively. Kinetic results show the same trend as the relative gasification reactivities indicated earlier. These results further indicate that using kinetic parameters found in the literature for a particular application should be done with circumspection. For instance, wen and Chuang's data would over-predict PSC char gasification performance in the present temperature range by a factor of at least five.

Kinetic parameters for JRC char gasification in steam were estimated from a limited number of data points. Preliminary results showed a much higher activation energy ( $75900 \mathrm{cal} / \mathrm{mole}$ ) than found for gasification in carbon dioxide $(42470 \mathrm{cal} / \mathrm{mole})$. The ratios of $\mathrm{K}_{\mathrm{S}}$, i.e., $\left(\mathrm{K}_{\mathrm{S}}\right)_{\mathrm{C}-\mathrm{H}_{2} \mathrm{O}} /\left(\mathrm{K}_{\mathrm{S}}\right)_{\mathrm{CO}}=\left[2.79 \times 10^{7} \exp \right.$ $(-75900 / R T)] /[1040 \exp (-42470 / R T)]$, are $0.12,0.67$, and 4.22 at 2000,2400 , and $3000^{\circ} \mathrm{F}$, respectively. This information indicates that $\mathrm{C}-\mathrm{H}_{2} \mathrm{O}$ reaction is more efficient than $\mathrm{C}-\mathrm{CO}_{2}$ reaction at higher temperatures $\left(\sim 3000^{\circ} \mathrm{F}\right)$, but it is less efficient at lower temperatures. This interesting trend shows the need to further quantify the DTFS-derived kinetic parameters of coal char gasification in steam. 


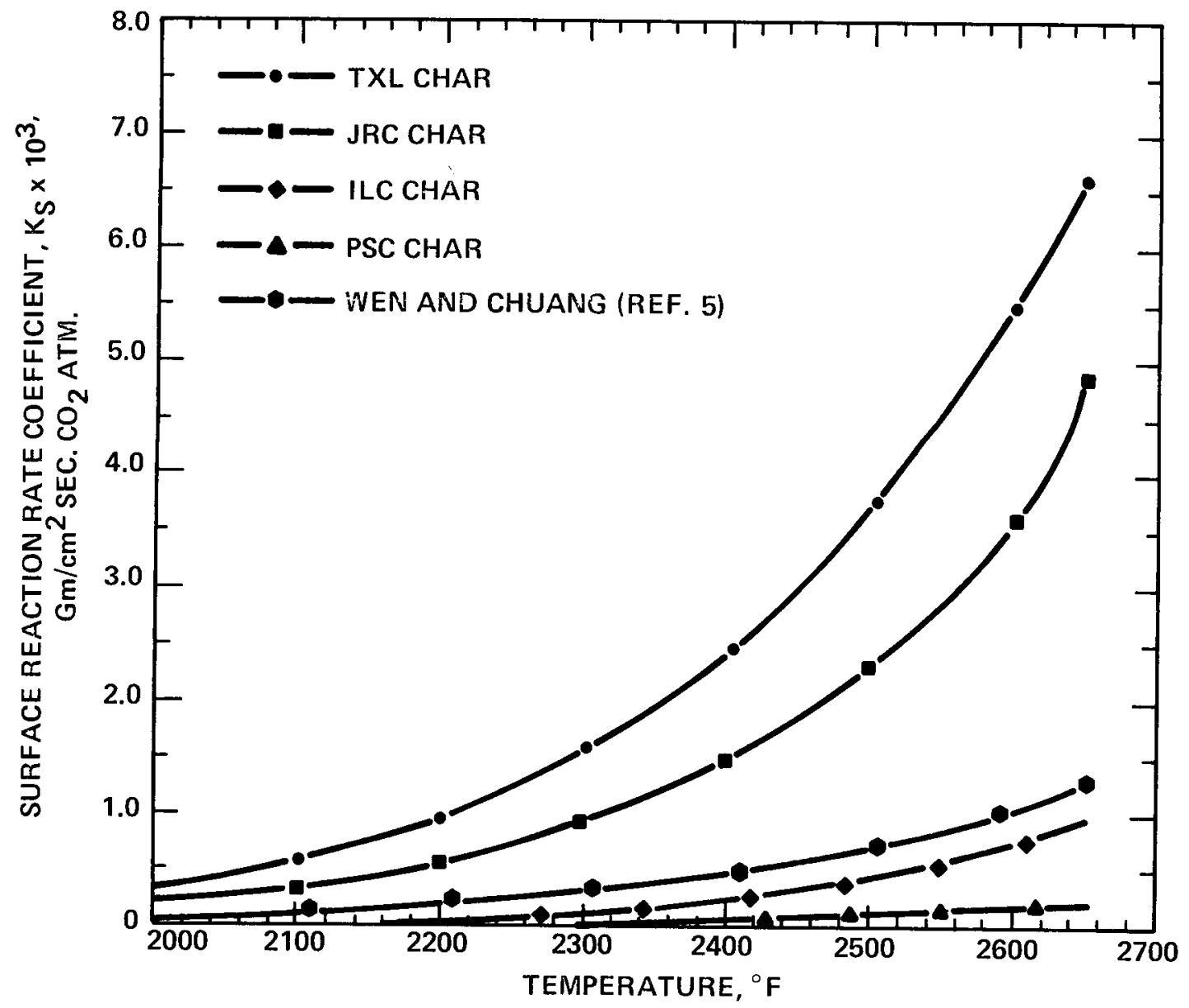

FIGURE 4-20 VARIATION OF GASIFICATION SURFACE REACTION RATE COEFFICIENT WITH TEMPERATURE FOR VARIOUS CHARS IN THE DTFS 
The gasification kinetic reaction order with respect to carbon dioxide concentration $\left[\mathrm{CO}_{2}\right]$ was evaluated for PSC char following the same procedure outlined earlier in the section on "Combustion of Chars". That is

$$
\mathrm{K}_{\mathrm{S}}=\mathrm{K}^{\prime}\left[\mathrm{CO}_{2}\right]^{\mathrm{n}}
$$

where $K_{S}, K^{\prime}$, and $n$ are as explained in Eq. (4-1).

Equation (4-3) can be expressed as

$$
\ln K_{5}=\ln K^{\prime}+n \ln \left[\mathrm{CO}_{2}\right]
$$

A plot of $\ln K_{S}$ vs. In $\left[\mathrm{CO}_{2}\right]$ gives a straight line whose slope is equal to $n$. This method was used as shown in Table 4-14 and Figure 4-21. The value of $n$ in this figure is equal to 0.91 , which is very close to first order. Knight and Sergeant (8) found a value of 0.7 from their thermo-gravimetric studies of Australian coal chars. Wen et a1. (20) used first order reaction kinetics with respect to $\mathrm{CO}_{2}$ concentration in their TGA coal gasification studies. Computer printouts of char gasification data are given in Appendix $C$.

Table 4-14

OATA FOR EVALUATING GASIFICATION REACTION

\begin{tabular}{|c|c|c|c|}
\hline $\begin{array}{l}{\left[\mathrm{CO}_{2}\right]} \\
\% \\
\end{array}$ & $\ln \left[\mathrm{CO}_{2}\right]$ & $\begin{array}{l}\left.\mathrm{K}_{\mathrm{S}}^{\prime}=\overline{\mathrm{K}}_{\mathrm{S}} \times \mathrm{CO}_{2} \mathrm{CO}_{2}\right]^{\star} \\
\mathrm{g} \mathrm{cm}{ }^{-1} \mathrm{sec}^{-1}\end{array}$ & $\ln K_{S}^{\prime}$ \\
\hline 15 & 2.71 & 0.0024 & -6.03 \\
\hline 30 & 3.40 & 0.0070 & -4.96 \\
\hline 60 & 4.09 & 0.0084 & -4.78 \\
\hline
\end{tabular}
ORDER OF $200 \times 400$ MESH PSC CHAR

$\overline{* \bar{K}_{S}}$ are averages of $K_{S}$ values found at each carbon dioxide partial pressure. 


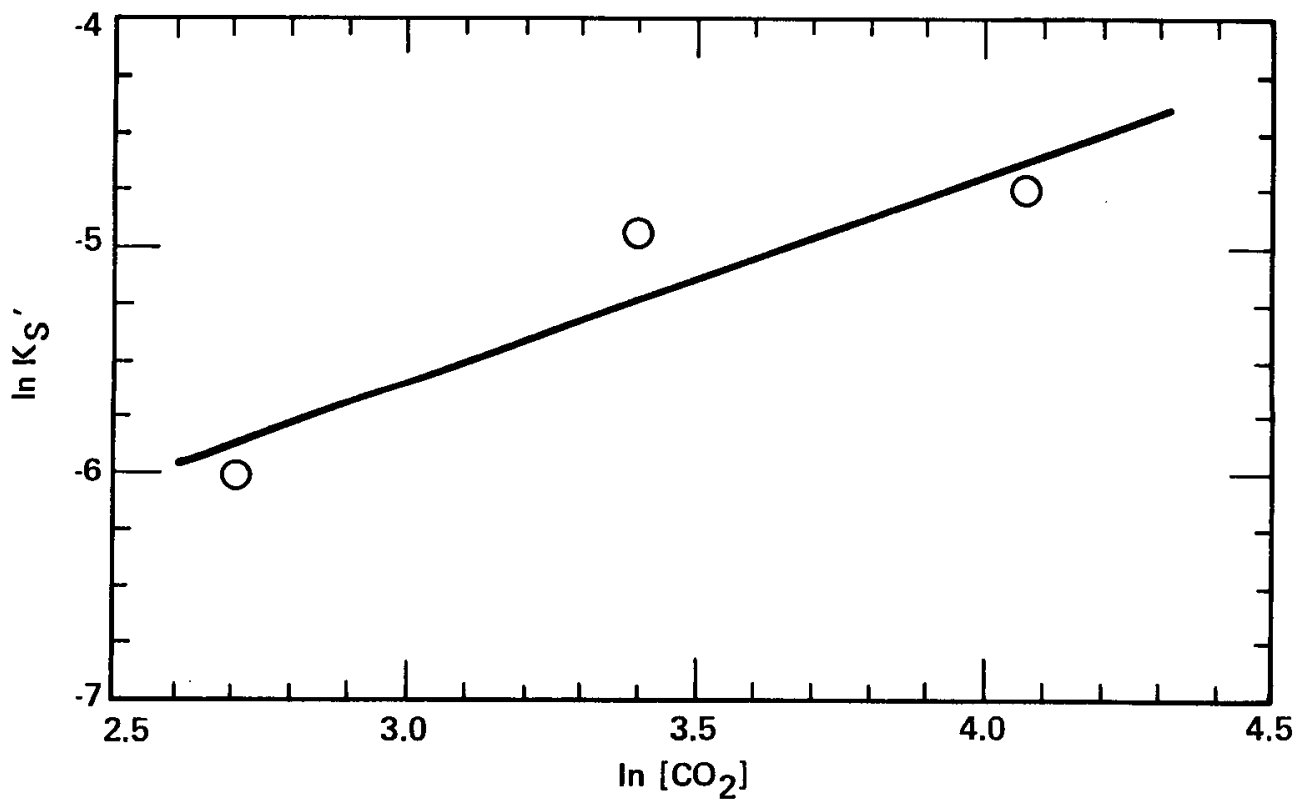

FIGURE 4-21 VARIATION OF In $\mathrm{K}^{\prime}$ ' INITH In [ $\mathrm{CO}_{2}$ ] FOR 200×400 MESH PSC CHAR GASIFICÁTION IN THE DTFS AT $2650^{\circ} \mathrm{F}$ GAS TEMPERATURE 
Comparison Between Combustion and Gasification Reaction Rates of Chars

Reaction rate coefficients $\left(K_{S}\right)$ calculated from combustion and gasification kinetic parameters of each char are compared in Table 4-15.

Table 4-15

RATIOS OF COMBUSTION TO GASIFICATION SURFACE

REACTION RATE COEFFICIENTS OF $200 \times 400$ MESH CHARS

\begin{tabular}{|c|c|c|c|c|c|}
\hline \multicolumn{2}{|c|}{ Temperature } & $\frac{145}{1040}$ & $\begin{array}{l}\text { JRC Char } \\
\exp (-19970 / R T) \\
\exp (-42470 / R T)\end{array}$ & $\begin{array}{c}\text { ILC Char } \\
\frac{60 \exp (-17150 / R T)}{12950 \exp (-56360 / R T)}\end{array}$ & $\begin{array}{c}\text { PSC Char } \\
66 \exp (-20360 / R T) \\
1390 \exp (-53700 / R T) \\
\end{array}$ \\
\hline $\begin{array}{l}2000 \\
2200 \\
2400 \\
2600 \\
2650\end{array}$ & $\begin{array}{l}1366 \\
1477 \\
1589 \\
1700 \\
1727\end{array}$ & & $\begin{array}{r}558 \\
2.98 \\
174 \\
109 \\
98\end{array}$ & $\begin{array}{r}8,765 \\
2,959 \\
1,153 \\
512 \\
427\end{array}$ & $\begin{array}{r}10,318 \\
4,098 \\
1,840 \\
923 \\
791\end{array}$ \\
\hline
\end{tabular}

Results in Table 4-15 show that char combustion rates are two to four orders of magnitude greater than their corresponding gasification rates and that the ratios of combustion to gasification rates decrease with increasing temperature and decreasing coal rank. The former effect is due to the higher activation energies associated with gasification indicating that it is more temperature sensitive than combustion. These results point to the trend given by walker et al. (19). For example, extrapolating PSC results to $1472^{\circ} \mathrm{F}\left(800^{\circ} \mathrm{C}\right)$ yields a ratio of $3 \times 10^{5}$. The comparable value of Walker et. al. at $1470^{\circ} \mathrm{F}$ and 0.1 atmospheric pressure is $1 \times 10^{5}$.

Surface Area - Reactivity Relationships

The BET pore surface areas $\left(\mathrm{S}_{\mathrm{BET}}\right)$ of $200 \times 400$ mesh chars (Table 4-4) are plotted against combustion and gasification surface reaction rate coefficients $\left(K_{S}\right)$ calculated at $2650^{\circ} \mathrm{F}$ using kinetic parameters obtained from this study (Tables 4-9 and 4-13). Results are given in Figure 4-22. They indicate that: (1) as the BET surface areas increase from 13 to $97 \mathrm{~m}^{2} / \mathrm{g}$, the combustion surface reaction rate coefficients increase from 0.175 to $0.429 \mathrm{~g} \mathrm{~cm}^{-2} \mathrm{sec}^{-1} \mathrm{~atm}^{-1}$; and (2) as the BET surface areas increase from 13 to $213 \mathrm{~m}^{2} / \mathrm{g}$, the gasification surface reaction rate coefficients increase from 0.000227 to $0.00663 \mathrm{~g} \mathrm{~cm}^{-2} \mathrm{sec}^{-1} \mathrm{~atm}^{-1}$. 


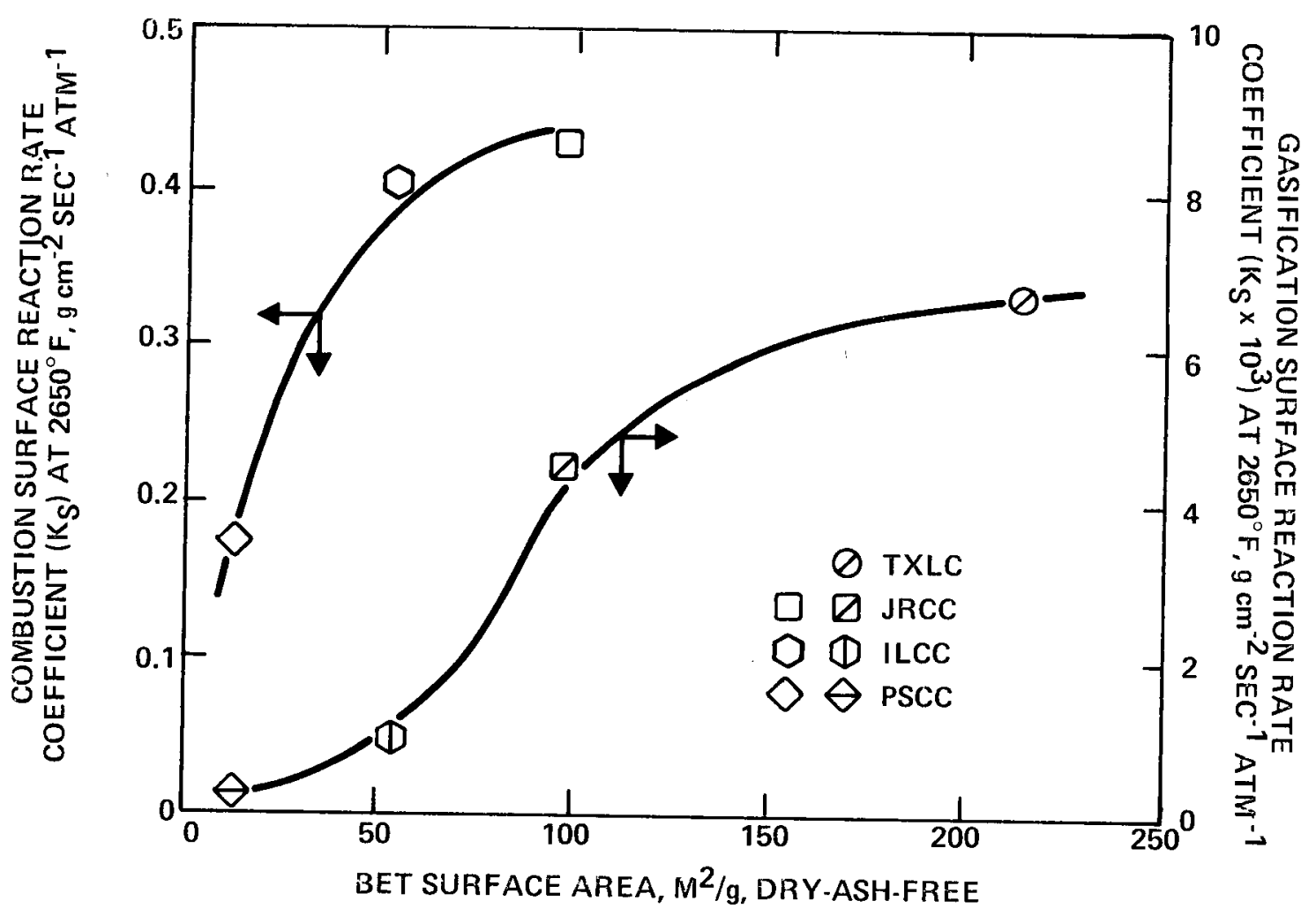

FIGURE 4-22 RELATIONSHIP OF BET PORE SURFACE AREA $\left(S_{B E T}\right)$ WITH DTÏS COMBUSTION AND GASIFICATION SURFACE REACTION RATE COEFFICIENTS $\left(K_{S}\right)$ FOR $200 \times 400$ MESH CHARS 
The qualitative shapes of the $S_{B E T}-K_{S}$ curves in Figure 4-22 are strikingly similar to those exhibited by $S_{B E T}{ }^{-R_{T}}$ relationships (Figure $4-3$ ). This underscores the fact that char combustion and gasification in entrained and fixed bed reactors are controlled to a large extent by a common parameter, internal pore surface area, and that fuels with greater internal areas are more reactive.

Morphology of Coals and Chars

Coals and chars sized to $200 \times 400$ mesh were observed under a Scanning Electron Microscope (SEM) to examine the surface structure of their particles. Some partially reacted chars were also examined similarly to study particle surface structure changes during char gasification and combustion in the Drop Tube Furnace System (DTFS). Results are presented in micrographic form in Figures 4-23 through 4-27.

Figure 4-23 shows the micrographs of coals. Coal particles appear angular in shape with no visible internal cavities. The physical appearance of these coal particles show no discernible correlation with coal rank.

Figures 4-24 through 4-27 show micrographs of: (1) $200 \times 400$ mesh pyrolysis chars (these chars were used as feed materials for subsequent char combustion and gasification studies); (2) gasification chars at various reaction zones; and (3) combustion chars at the sixteen-inch reaction zone.

Gasification and combustion chars from TXLC, Figure 4-24, are from $12^{\prime \prime}$ and $16^{\prime \prime}$ reaction zones, respectively. Gasification and combustion efficiencies at these positions are 61 and 85\%, respectively. The gasification char appears slightly more spherical than the pyrolysis char and also has larger surface defects. The combustion char appears different from the other two chars; it shows a predominance of globules which are ash constituents and a much more open porous structure representative of the latter stages of combustion of low rank fuel.

Figure 4-25 shows JRC gasification chars at 8 " and 16" reaction zones along with the pyrolysis char. The gasification efficiencies at these levels are 45 and $64 \%$, respectively. The surface defects on the pyrolysis char particles appear in the form of tiny holes. The particles of the 8 " gasification char have a predominance of surface fissures. At $16^{\prime \prime}$ char particles have a very open porous structure. In addition, some of the particles during the latter stages of gasification appear to have lost their structural integrity and have shattered into smaller pieces. 


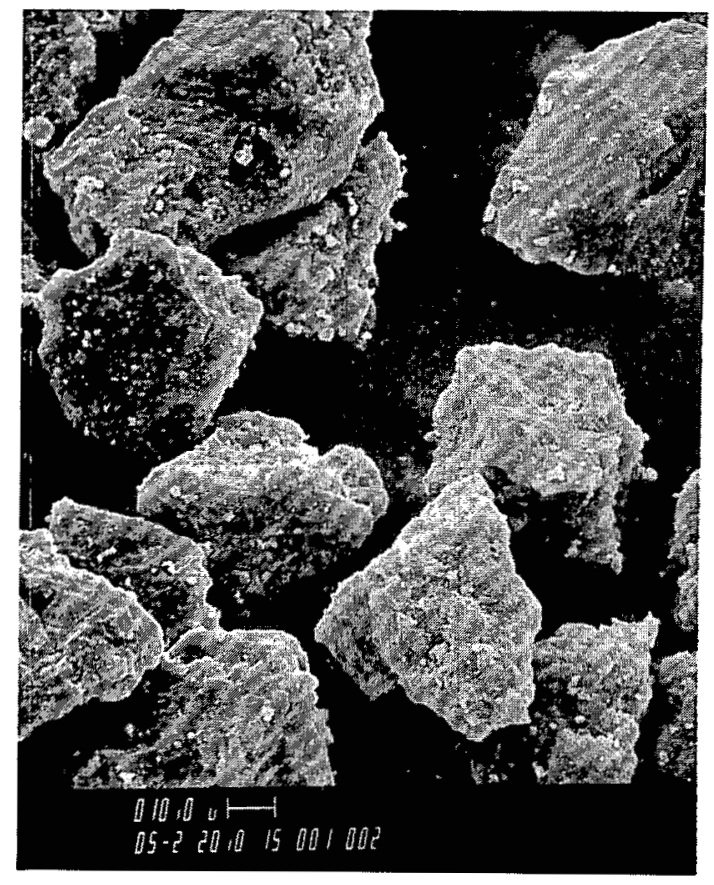

500X TXL LIGNITE

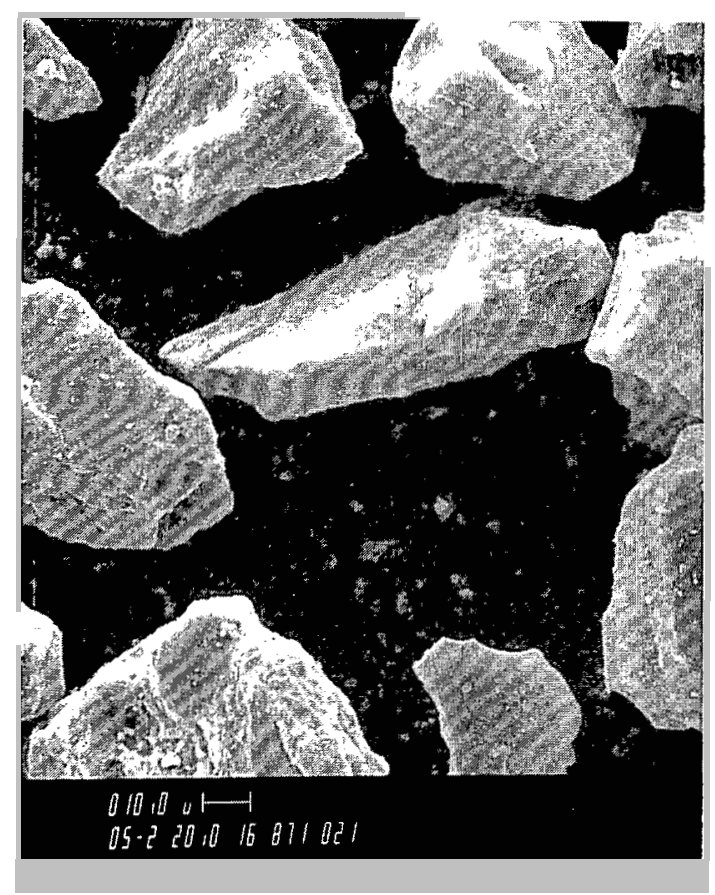

$500 X$ ILC HVCB

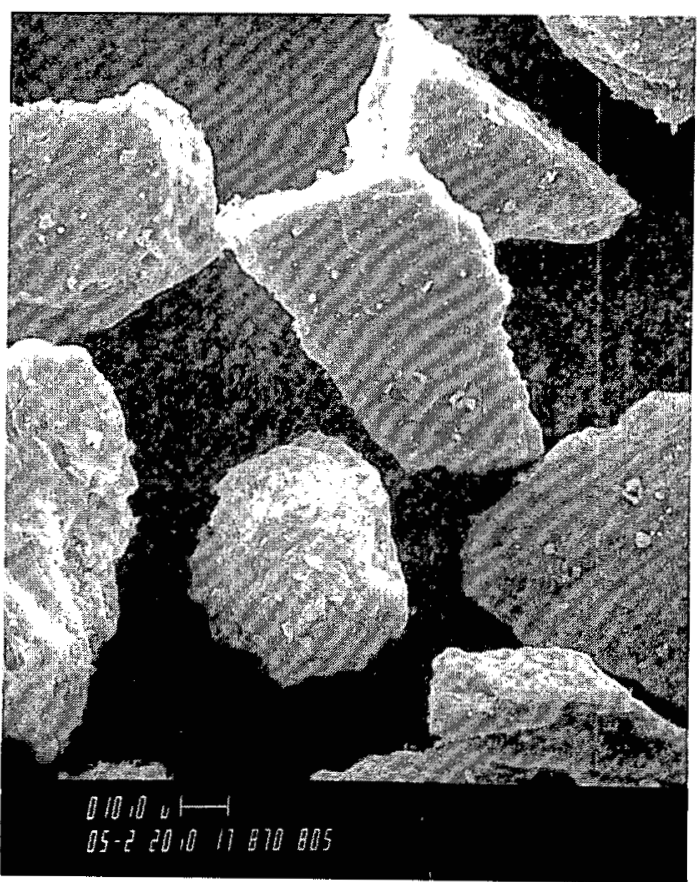

$500 \times$ JRC SUB C

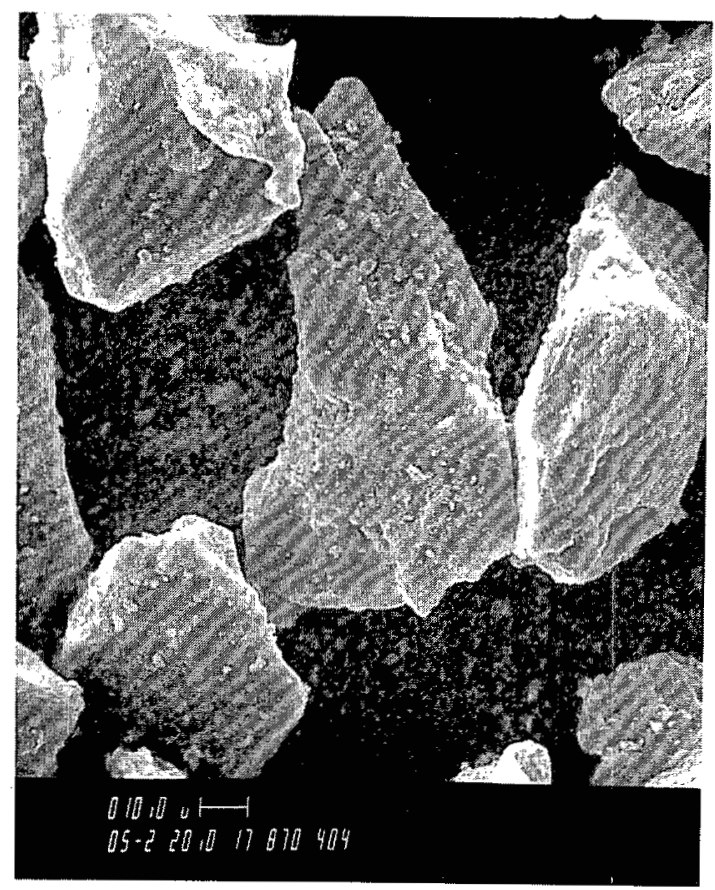

500X PSC HVAB

FIGURE 4-23 SCANNING ELECTRON MICROGRAPHS OF 200×400 MESH COALS 


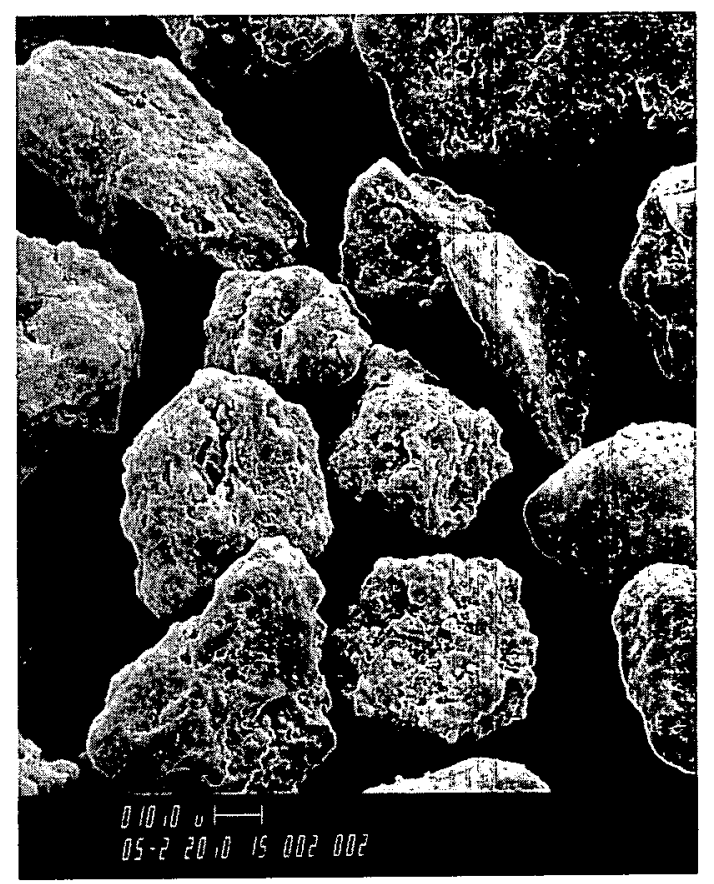

500X PYROLYSIS CHAR

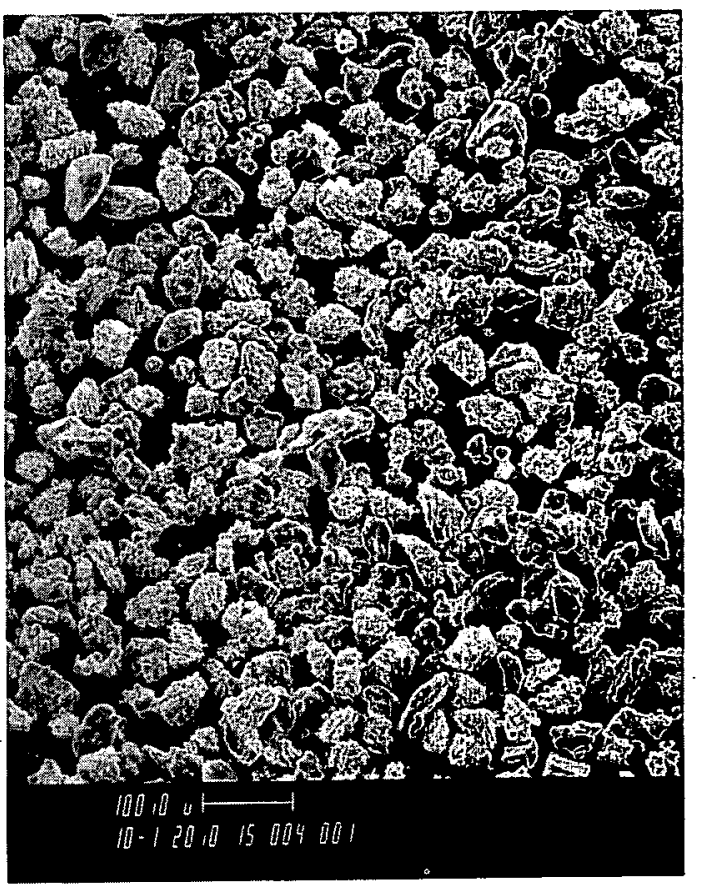

100X COMBUSTION CHAR DTFS-16"

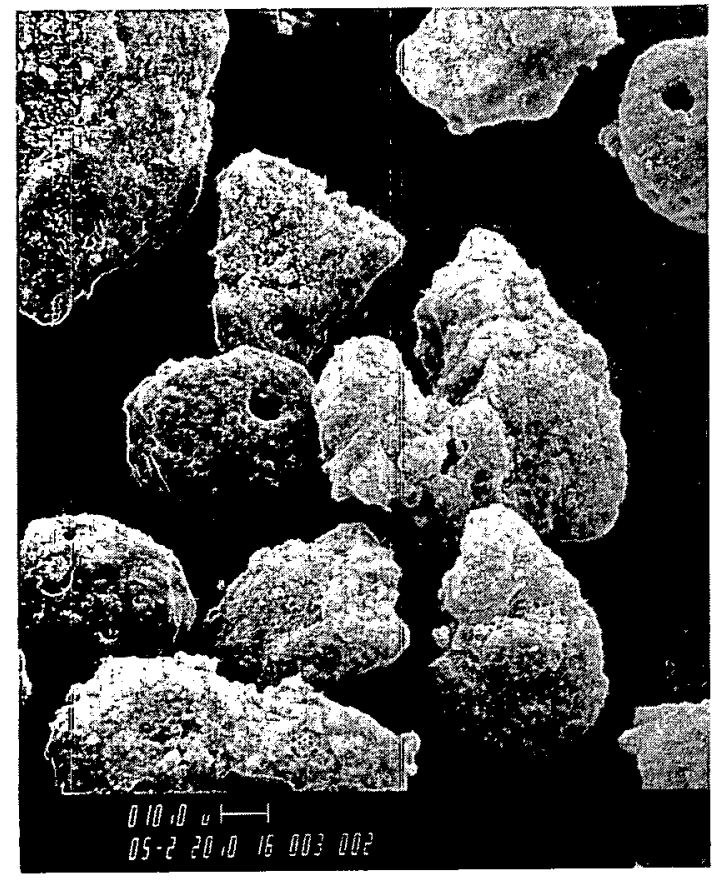

500X GASIFICATION CHAR DTFS-12"

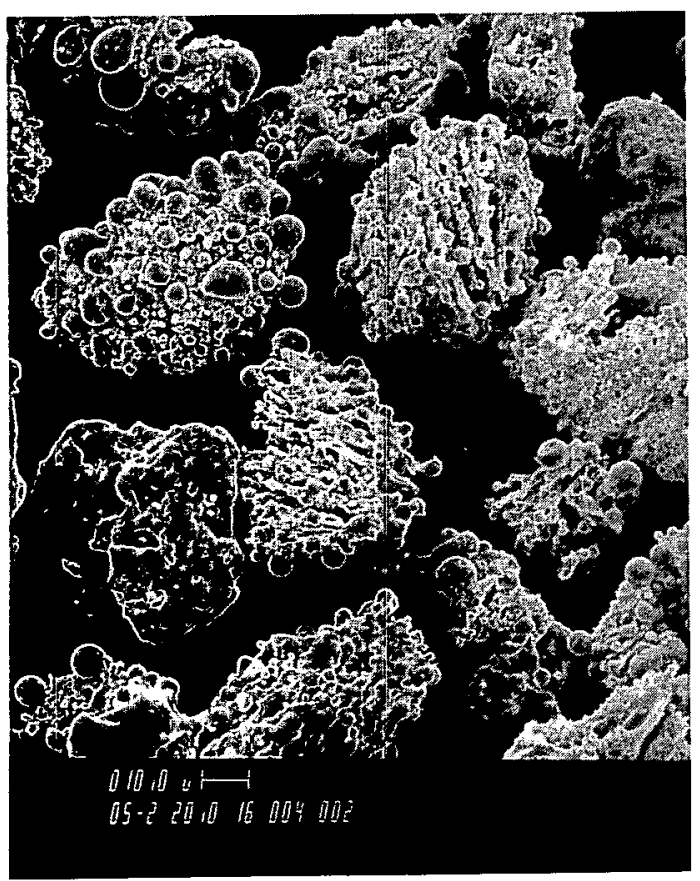

500X COMBUSTION CHAR DTFS-16"

FIGURE 4-24 SCANNING ELECTRON MICROGRAPHS OF TXL CHARS 


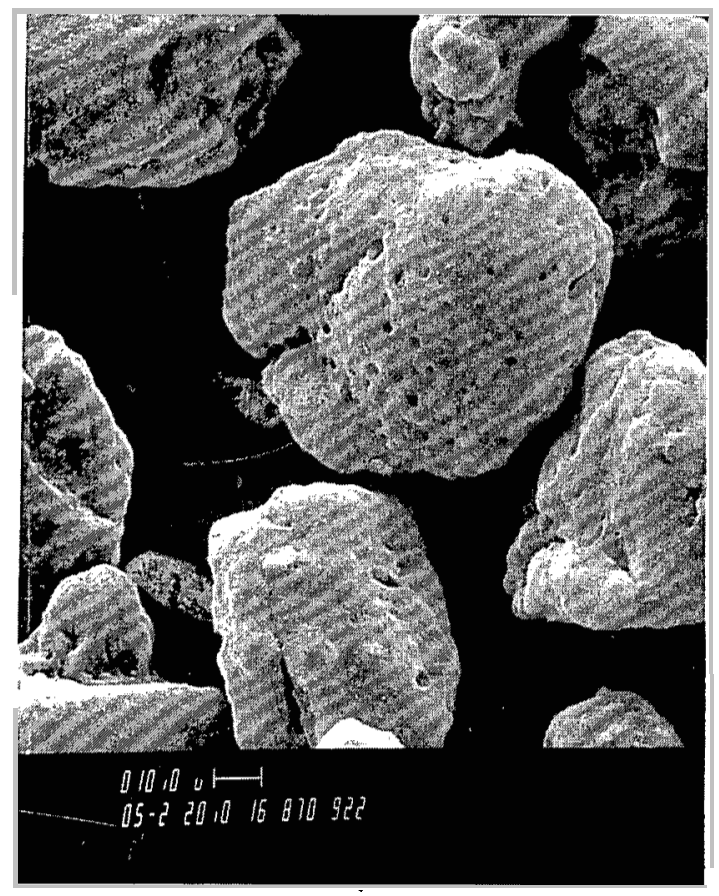

500X PYROLYSIS CHAR

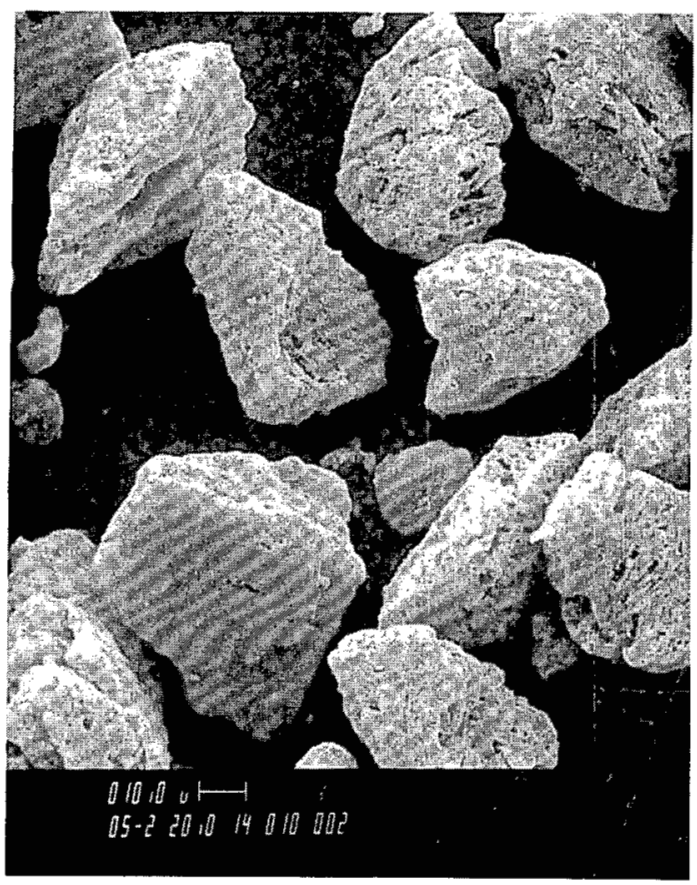

500X GASIFICATION CHAR DTFS-8"

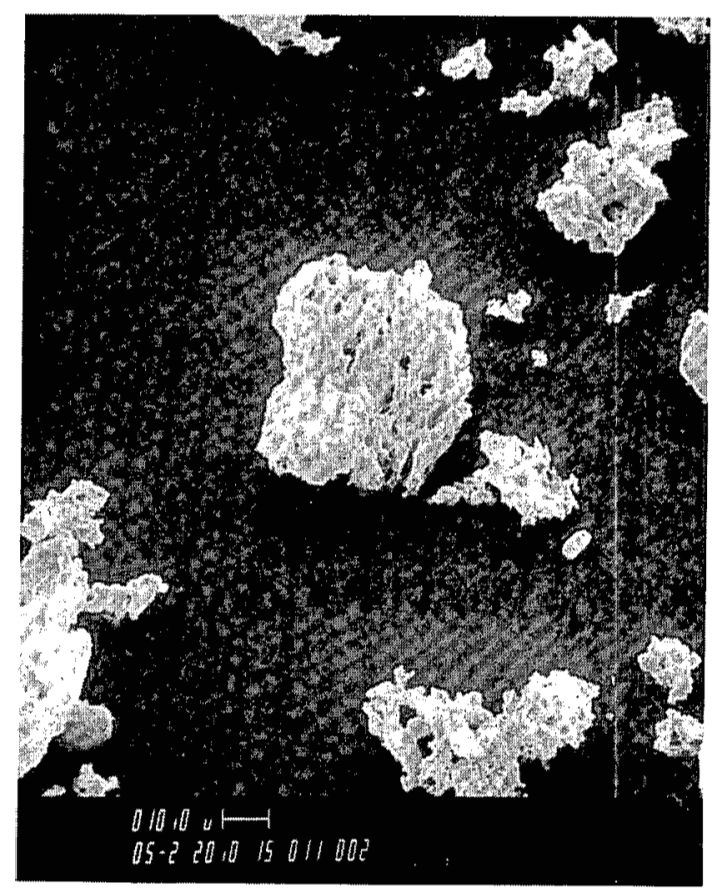

500X GASIFICATION CHAR DTFS-16"

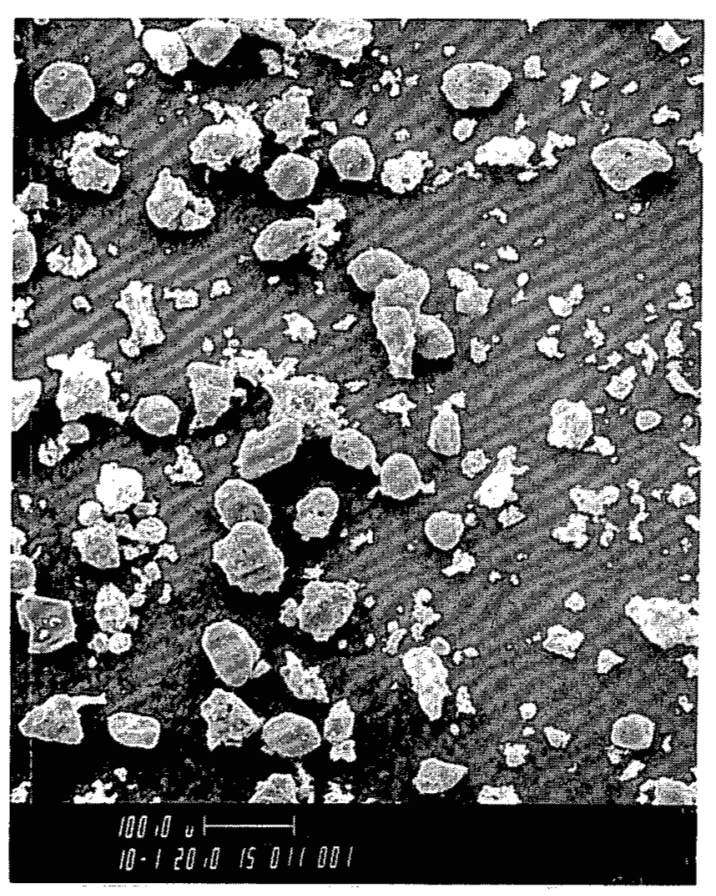

100X GASIFICATION CHAR DTFS-16" 


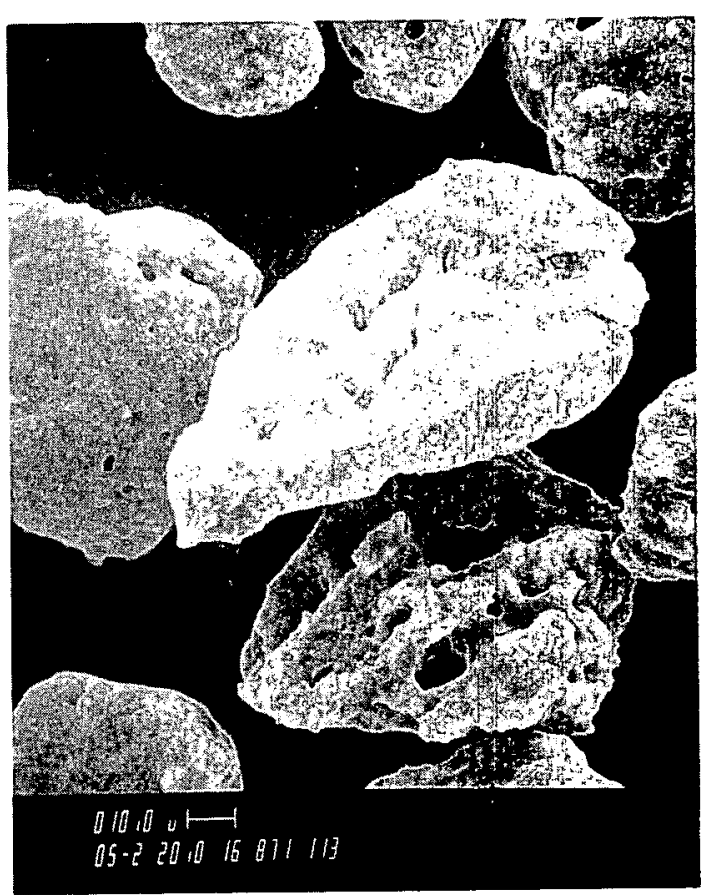

500X PYROLYSIS CHAR

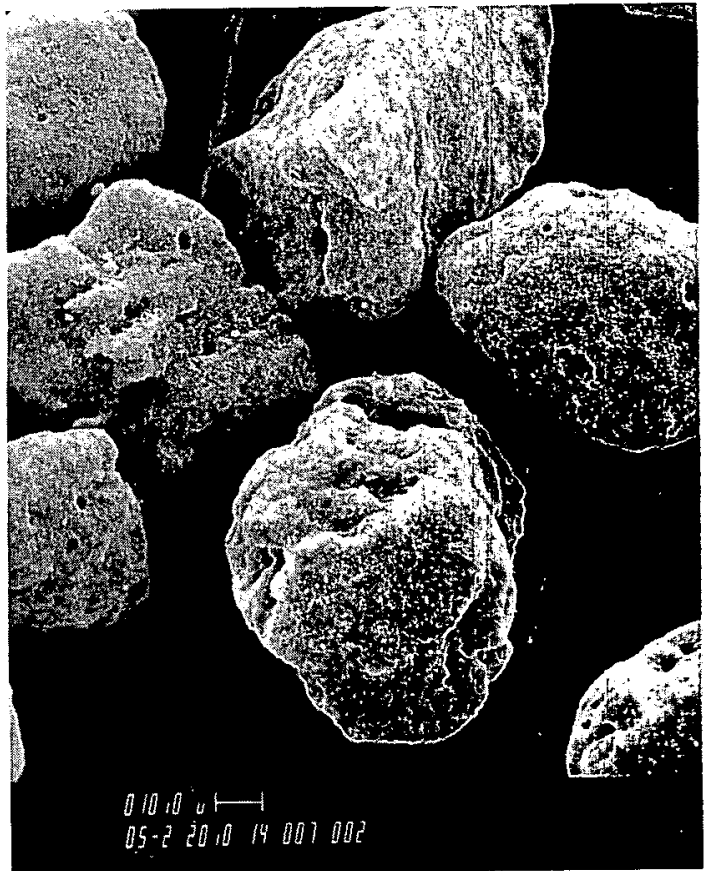

500X GASIFICATION CHAR DTFS-16"

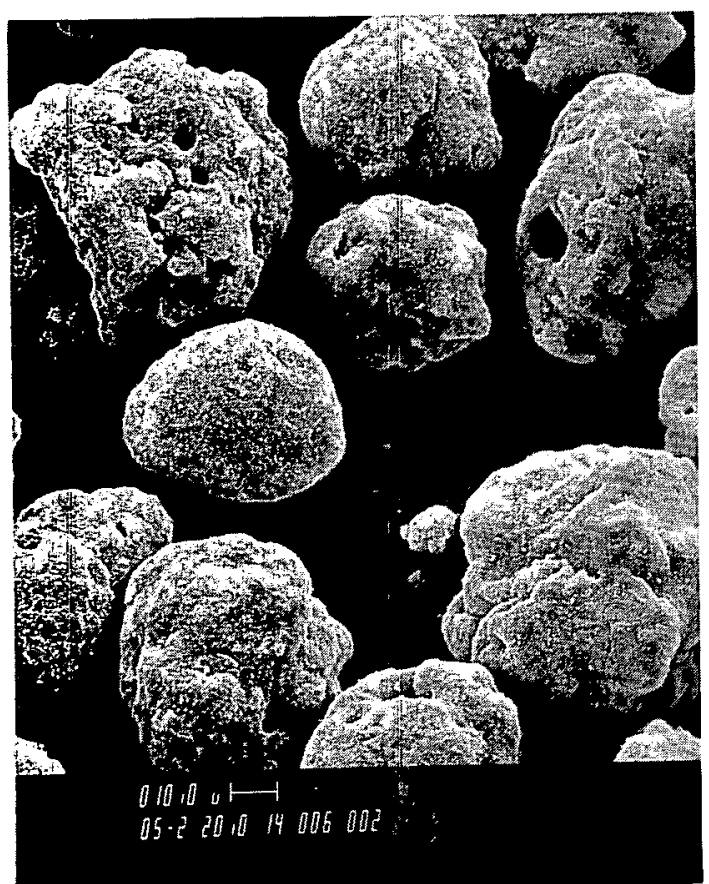

500X GASIFICATION CHAR DTFS-8"

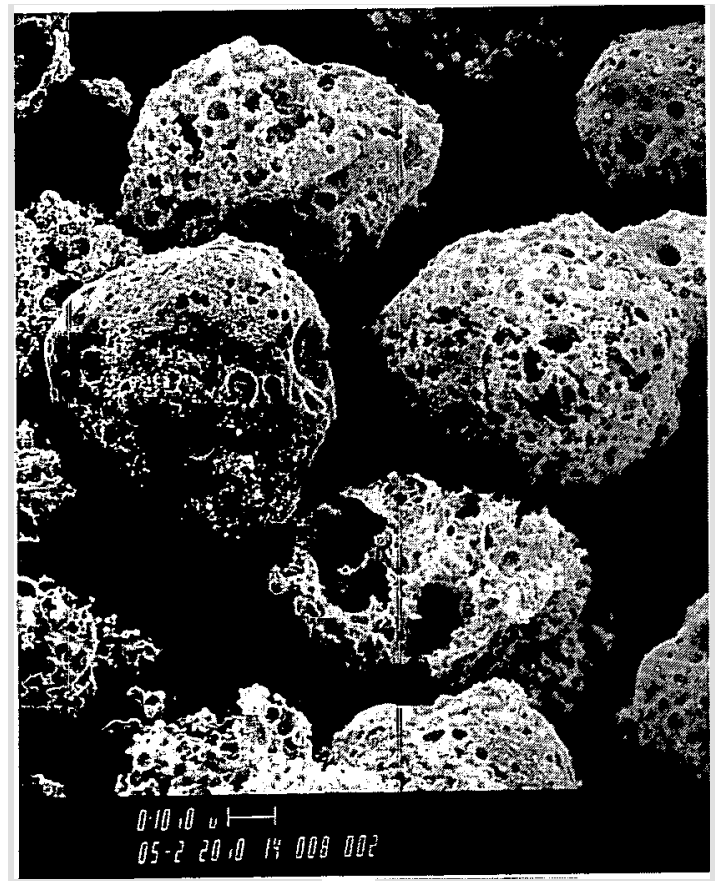

500X COMBUSTION CHAR DTFS-16"

FIGURE 4-26 SCANNING ELECTRON MICROGRAPHS OF ILC CHARS 


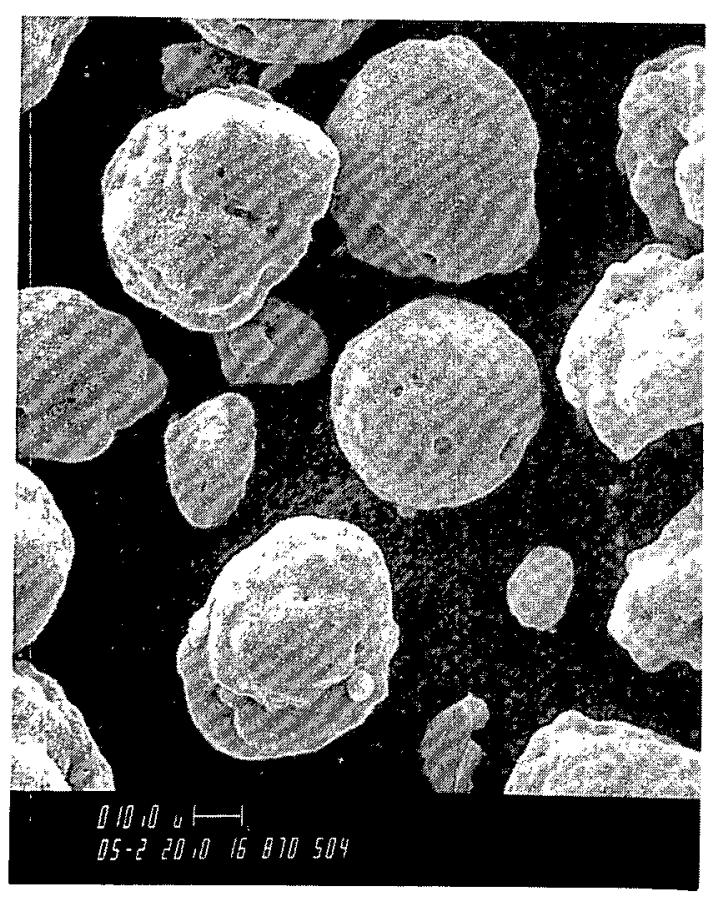

500X PYROLYSIS CHAR

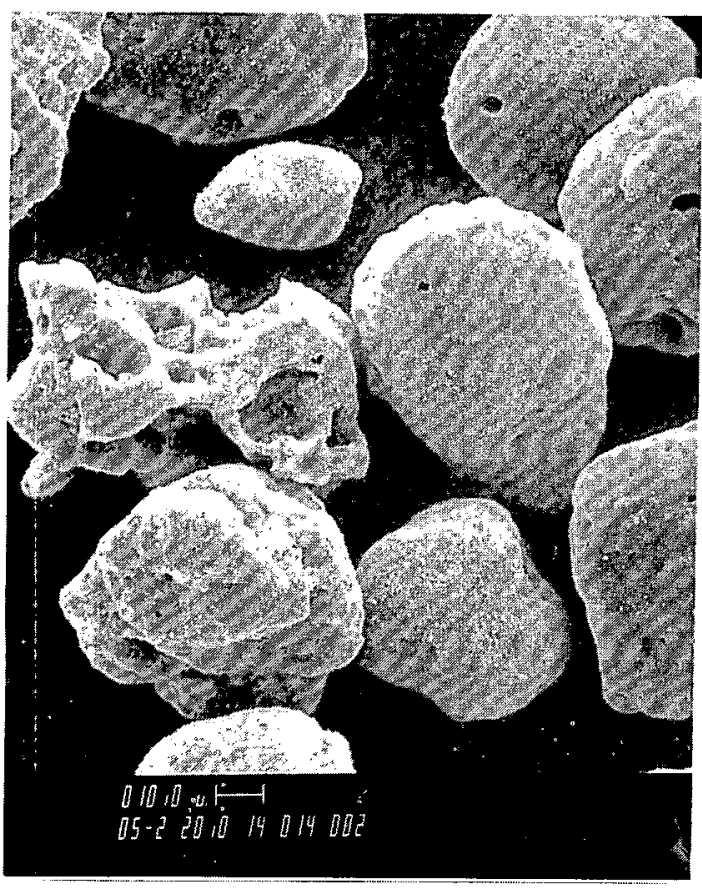

500X GASIFICATION CHAR DTFS-16"

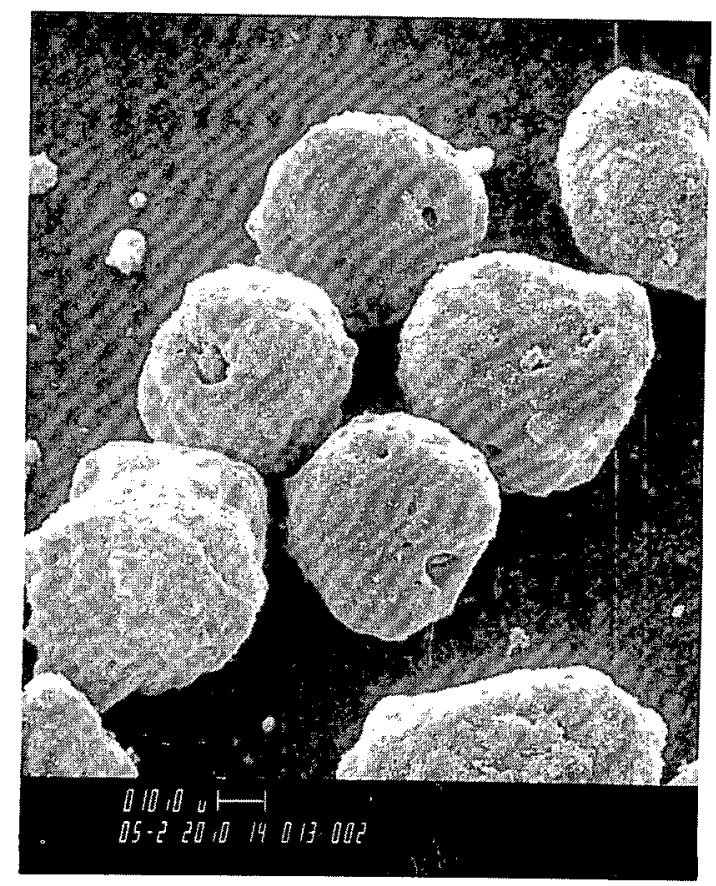

500X GASIFICATION CHAR DTFS-8"

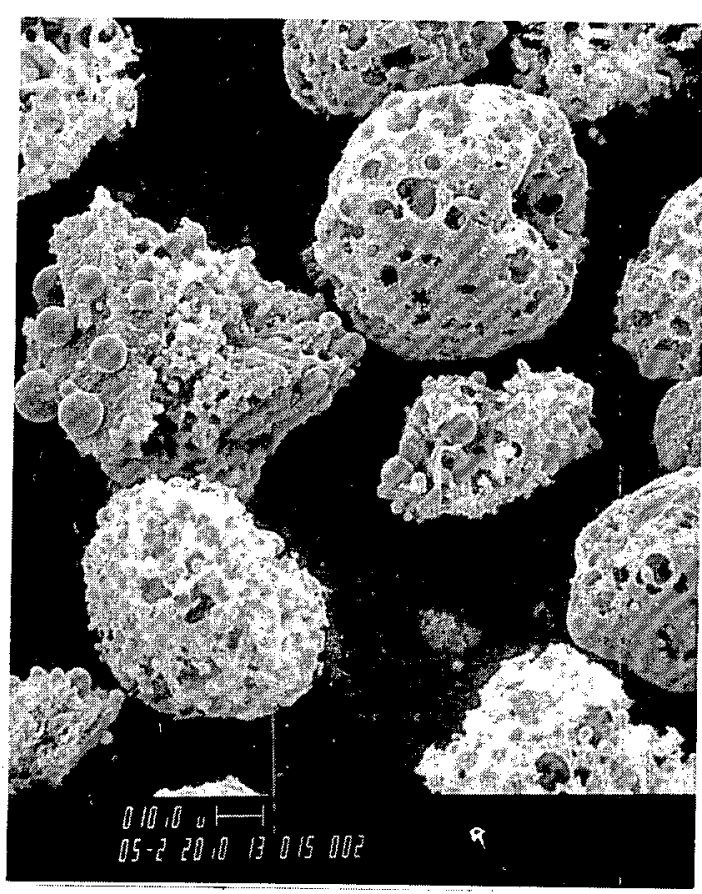

500X COMBUSTION CHAR DTFS-16"

FIGURE 4-27 SCANNING ELECTRON MICROGRAPHS OF PSC CHARS 
The micrographs of the ILC chars are given in Figure 4-26. Gasification efficiencies at $8^{\prime \prime}$ and $16^{\prime \prime}$ are 7 and $17 \%$, respectively, and combustion efficiency at $16^{\prime \prime}$ is $95 \%$. Pyrolysis and gasification chars do not appear to be materially different. Surface defects appear in the form of large holes. The combustion char particles also appear different from the other chars. Their surfaces look relatively porous. Globule ash constituents are also abundant.

Figure 4-27 depicts micrographs of PSC chars. Gasification efficiencies at 8" and $16^{\prime \prime}$ reaction zones are 2 and $6 \%$, respectively, and combustion efficiency at $16^{\prime \prime}$ reaction zone is $73 \%$. Again, no significant differences are found between pyrolysis and gasification char particles. Particles are fairly spherical in shape and have only a few defects in the form of holes. This is typical of agglomerating coals which go through a plastic stage during pyrolysis; they assume a more spherical shape and result in a closed pore structure. The combustion char looks somewhat similar to ILC combustion char. That is, it is relatively porous and has an abundance of globule ash constituent. The TXL char appears somewhat more porous.

The surface defects found in gasification and combustion char particles (Figures 4-24 through 4-27) are indicative of varying degrees of porosity of these chars. They also indicate that both char gasification and combustion are controlled to a large extent by the same physical phenomenon, namely, the surface reaction. The very high porosity and large open pore structure of the TXL and JRC chars is largely responsible for their high reactivities. The agglomerating nature of the pittsburgh No. 8 coal and its subsequent formation of a spherical char with few surface defects is largely responsible for the relatively low reactivity of the PSC char. 
Section 5

APPLICATION

\section{DTFS PERFORMANCE PREDICTIONS}

The combustion/gasification model described in Appendix D was used in conjunction with the kinetic parameters (Activation Energies and Frequency Factors) obtained from this study to predict the performances of TXL, JRC, ILC, and PSC chars in the Drop Tube Furnace System (DTFS). In this manner, it is possible to generalize coal and char behavior in the Drop Tube Furnace System to anticipate performance and trends at conditions where experimental data may not have been taken.

\section{Char Combustion}

Results given in Figure 5- 1 show the effects of temperature and residence time on the predicted combustion efficiencies of JRC, ILC, and PSC $200 \times 400$ mesh chars. Experimental data points are shown for comparison. This figure generally shows good agreement between experimental and theoretical char combustion efficiency $(n)$ results, even though theory slightly over-predicts $n$ values at higher temperatures and longer residence times.

PSC char is further examined in more detail since its reactivity performance is lower than those of other chars. Three cases are presented based on the assumptions that this char is burned in air at an isothermal temperature of $3000^{\circ} \mathrm{F}$ and $-20,0$, and $10 \%$ excess air. Results, given in Figure 5-2, show that: (1) as expected, only $80 \%$ of the char can be burned at $-20 \%$ excess air; (2) at $0 \%$ excess air, $98 \%$ of the char is burned in 0.6 second; and (3) at $10 \%$ excess air, the char is burned to completion in $0.4 \mathrm{sec}$.

These results indicate that from an application standpoint the PSC char can be burned to completion in an adequate residence time given proper temperature and excess air. For instance, Figure 5-1 indicates that if the $3 \% \mathrm{O}_{2} / 97 \% \mathrm{~N}_{2}$ gas temperature were held isothermally at $3000^{\circ} \mathrm{F}$, the PSC char would burn to completion in about $0.6 \mathrm{sec}$. 


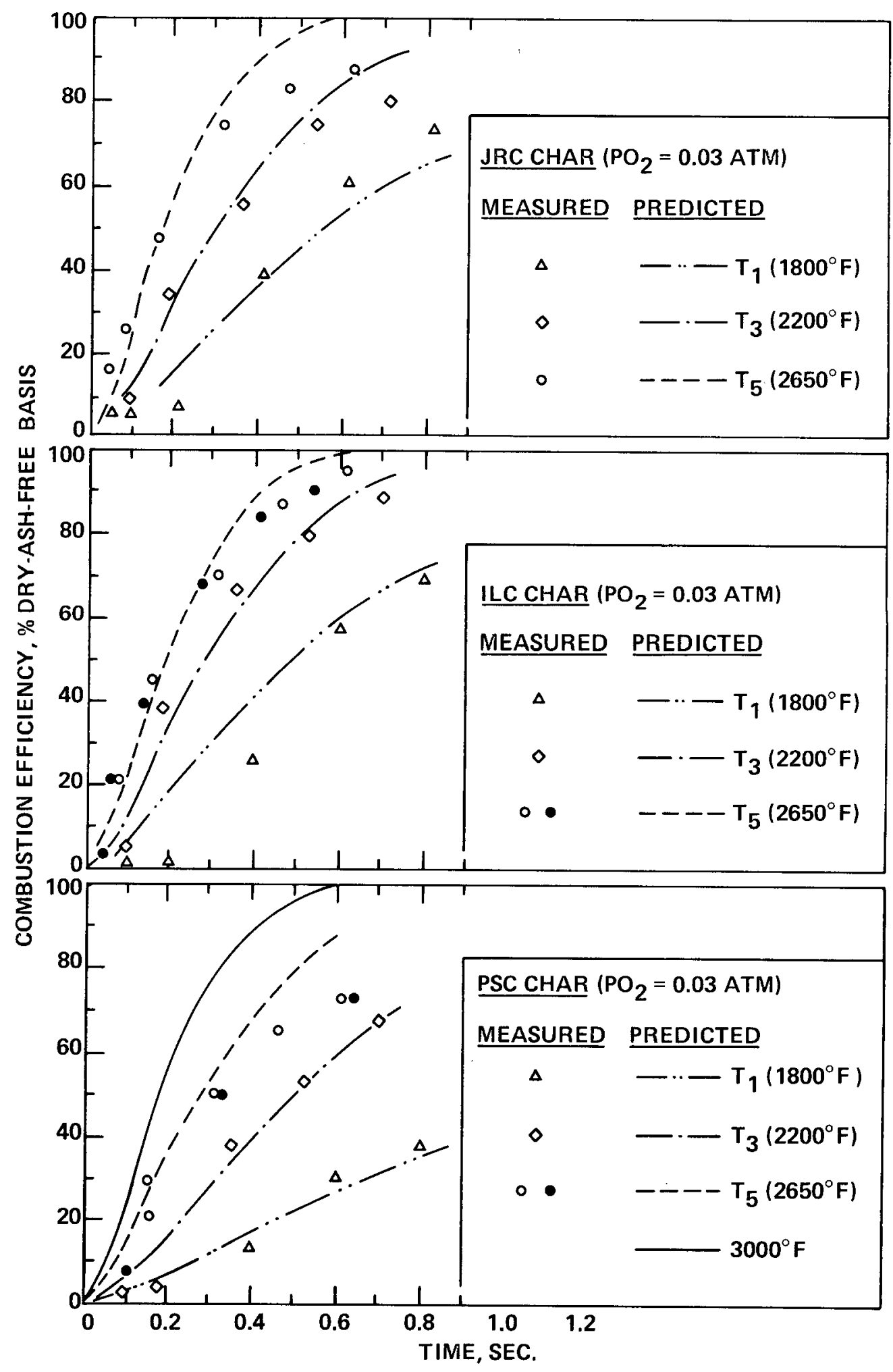

Figure 5-1 EFFECT OF GAS TEMPERATURE ON PREDICTED DTFS COMBUSTION EFFICIENCIES OF VARIOUS 200x400 MESH CHARS 


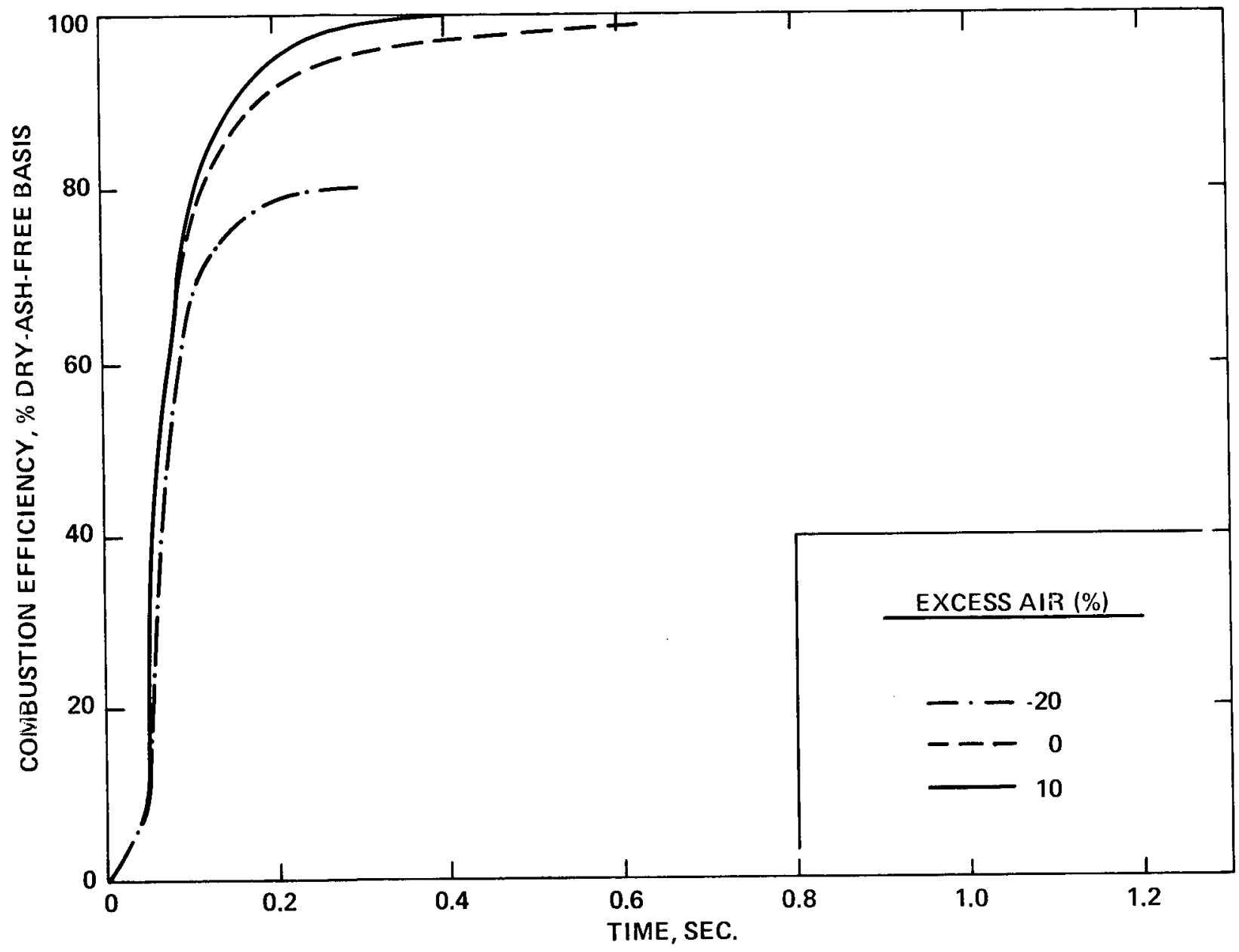

Figure 5-2 EFFECT OF PERCENT EXCESS AIR ON PREDICTED COMBUSTION EFFICIENCY OF $200 \times 400 \mathrm{MESH}$ PSC CHAR AT AN ISOTHERMAL TEMPERATURE OF $3000^{\circ} \mathrm{F}$ 


\section{Char Gasification}

Figures 5-3a and 5-3b show predicted gasification results in a $0.3 \mathrm{CO}_{2}$ atmosphere in nitrogen balance at different temperatures for TXL, JRC, ILC, and PSC $200 \times$ 400 mesh chars. Experimental data points are included for comparison. Figure 5-3 shows that temperature has a significant effect on gasification efficiency. For example, conversion efficiency can be increased by an order of magnitude (in a $0.5 \mathrm{sec}$. residence time) by increasing temperature by $600-800^{\circ} \mathrm{F}$. Figure $5-3$ shows that fuel property effects are also great. Even though an order of magnitude increase in gasification efficiency can be attained for the PSC char in going from $2200^{\circ} \mathrm{F}$ to $3000^{\circ} \mathrm{F}$, its gasification efficiency at $3000^{\circ} \mathrm{F}$ is only $16 \%$ at 0.5 sec. residence time.

The effect of $\mathrm{CO}_{2}$ partial pressure on predicted gasification efficiency of $200 \times$ 400 mesh PSC char at $2650^{\circ} \mathrm{F}$ gas temperature is shown in Figure 5-4. Experimental data points are included for comparison. It is evident that $\mathrm{CO}_{2}$ partial pressure has a favorable influence on gasification. However, since PSC char is so unreactive in carbon dioxide, an increase of $\mathrm{CO}_{2}$ partial pressure to one atmosphere from 0.6 atmosphere results in only $13 \%$ versus $7 \%$ conversion efficiency at 0.6 sec. residence time in the DTFS. Even though the first order effect of $\mathrm{CO}_{2}$ partial pressure is evident, the absolute amount of carbon conversion in both cases is small.

The effect of particle size on the predicted gasification efficiencies of JRC, ILC, and PSC chars was simulated. Two size grades were considered: $200 \times 400$ mesh (the same results given in Figures 5-3a and 5-3b) and -400 mesh obtained from grinding a portion of $200 \times 400$ mesh. It was found that the kinetic parameters developed on $200 \times 400$ mesh chars consistently over-predicted the performance of -400 mesh size fractions compared to experimental data points. More work needs to be done to scrutinize the dependency of kinetic parameters on particle size. Curve-fitting was achieved by adjusting the values of frequency factors (A) while keeping the activation energies (E) constant. The prediction of the -400 mesh PSC char performance was based on an adjusted $A$ value of $800 \mathrm{~g}$ $\mathrm{cm}^{-2} \mathrm{sec}^{-1} \mathrm{~atm}^{-1}$ from a value of $1390 \mathrm{~g} \mathrm{~cm}^{-2} \mathrm{sec}^{-1} \mathrm{~atm}^{-1}$ obtained from $200 \times 400$ mesh size fraction. The correspondingly adjusted $A$ values for predicting -400 mesh ILC and JRC chars are, respectively, $2500 \mathrm{~g} \mathrm{~cm}^{-2} \mathrm{sec}^{-1} \mathrm{~atm}^{-1}$ from $12950 \mathrm{~g} \mathrm{~cm}^{-2} \mathrm{sec}^{-1}$ $\mathrm{atm}^{-1}$ and $500 \mathrm{~g} \mathrm{~cm}^{-2} \mathrm{sec}^{-1} \mathrm{~atm}^{-1}$ from $1040 \mathrm{~g} \mathrm{~cm}^{-2} \mathrm{sec}^{-1} \mathrm{~atm}^{-1}$. Results are plotted in Figure 5-5. 


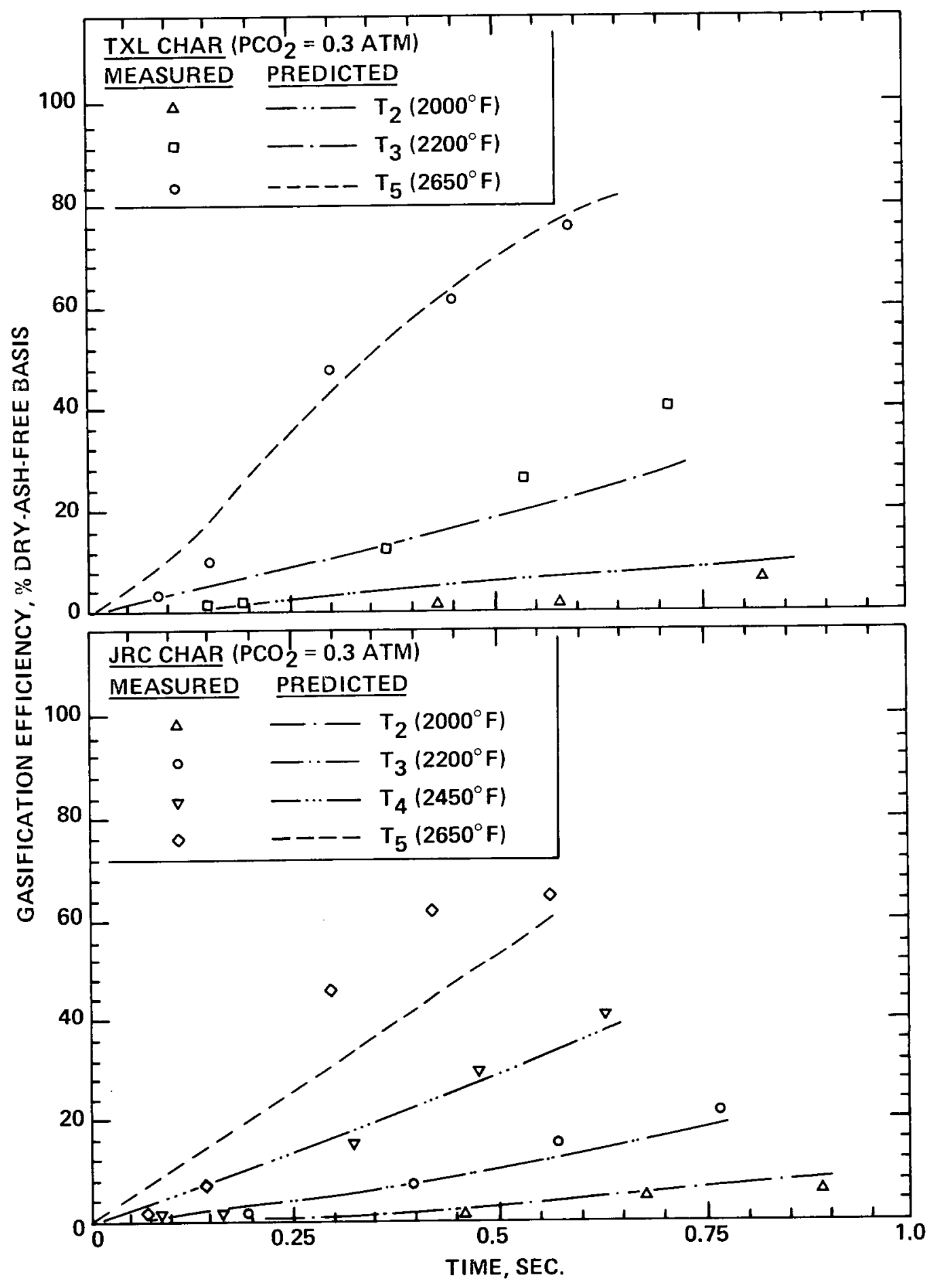

Figure 5-3a EFFECT OF GAS TEMPERATURE ON PREDICTED DTFS GASIFICATION EFFICIENCIES OF TXL AND JRC 200×400 MESH CHARS 


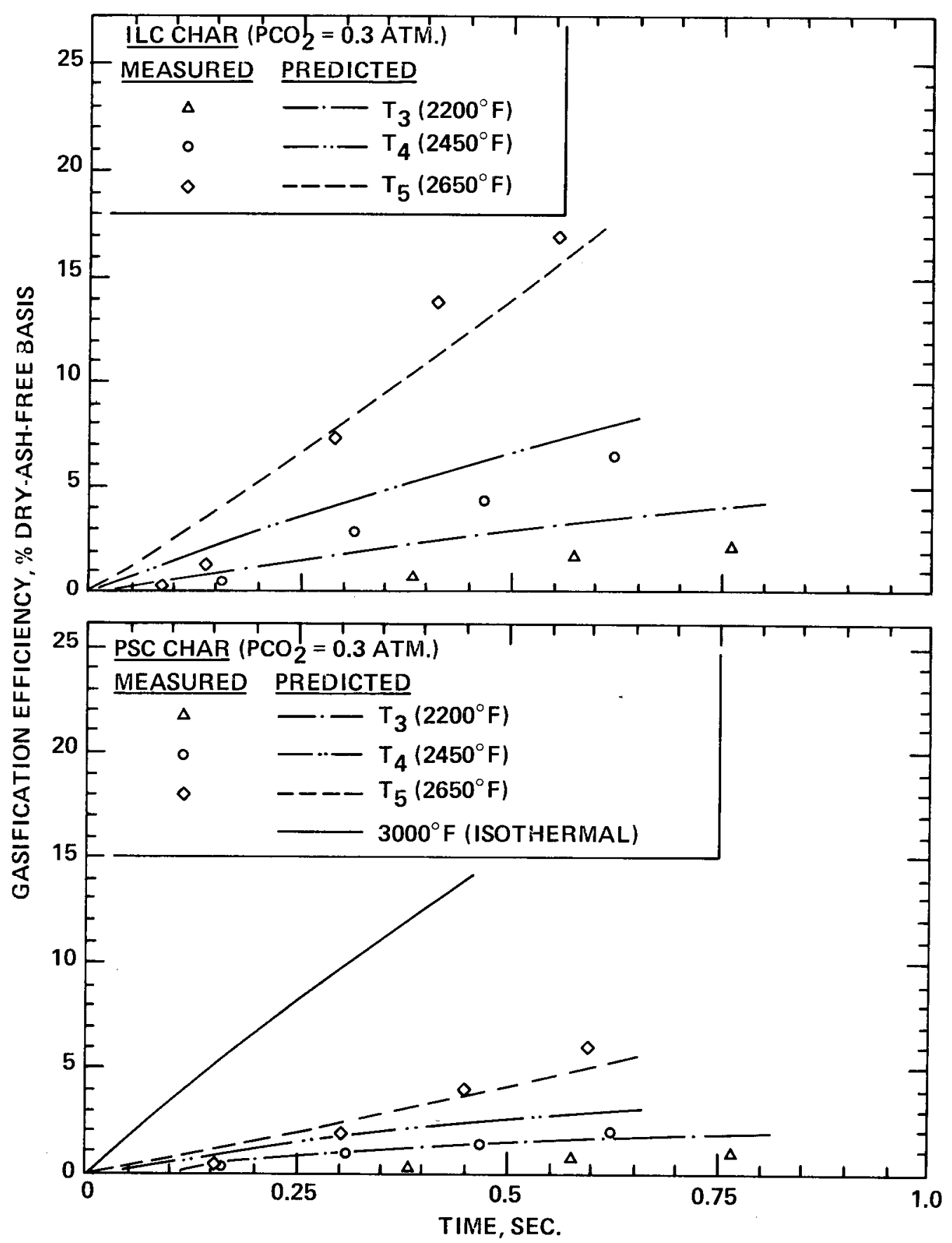

Figure 5-3b EFFECT OF GAS TEMPERATURE ON PREDICTED DTFS GASIFICATION EFFICIENCIES OF ILC AND PSC 200×400 MESH CHARS 


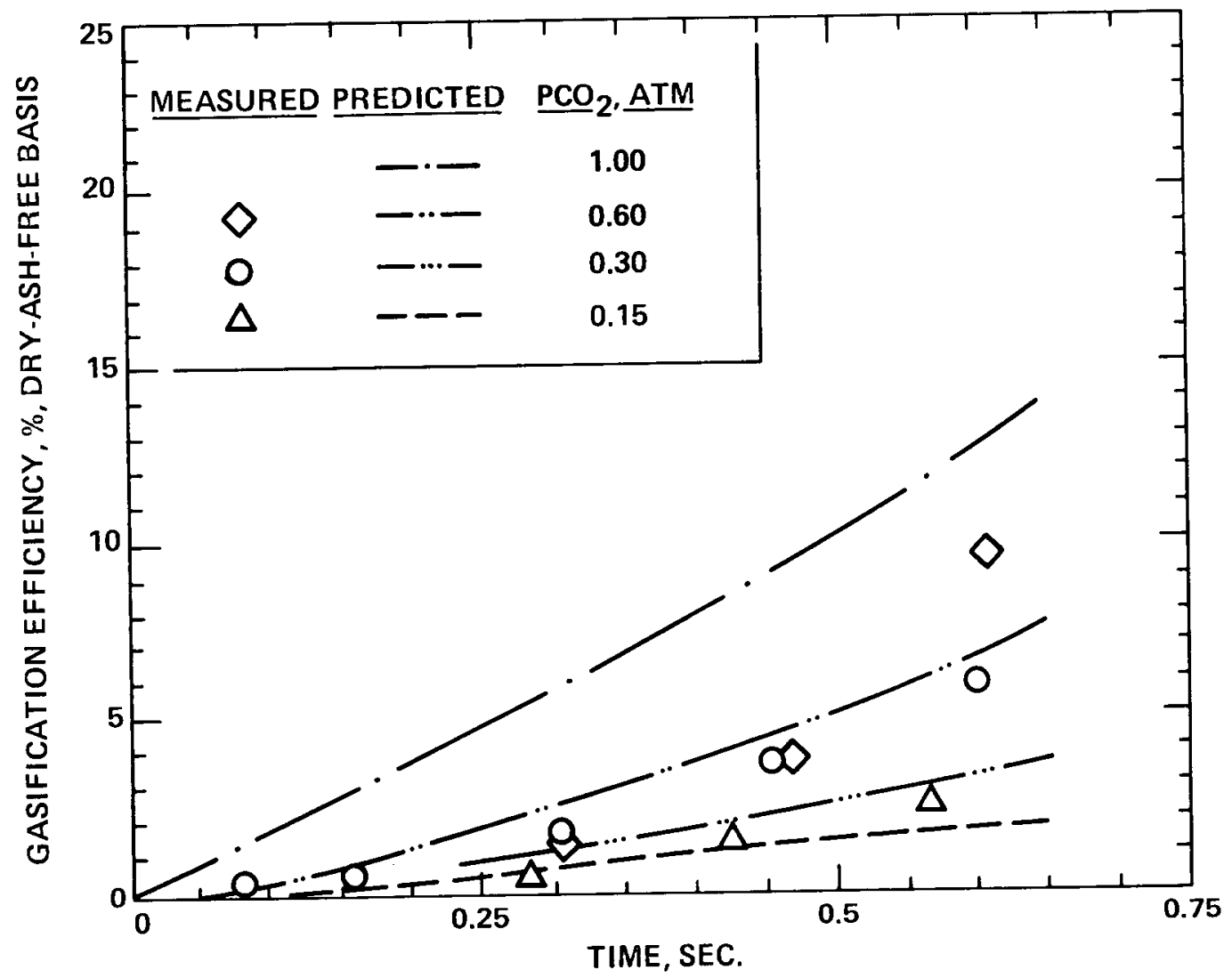

Figure 5-4 EFFECT OF CARBON DIOXIDE PARTIAL PRESSURE ON PREDICTED DTFS GASIFICATION EFFICIENCY OF 200x400 MESH PSC CHAR AT $2650^{\circ} \mathrm{F}$ GAS TEMPERATURE 


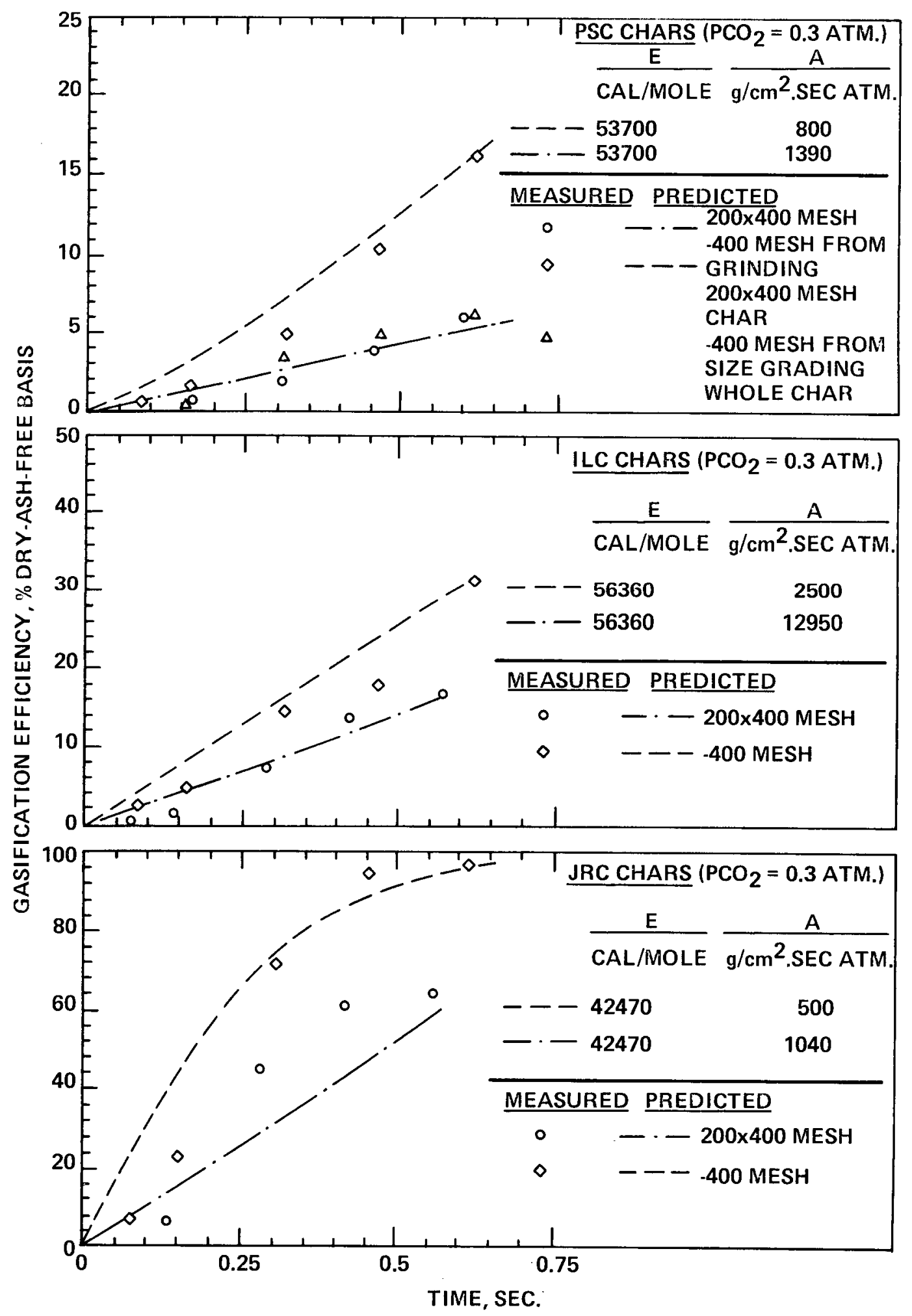

Figure 5-5 EFFECT OF PARTICLE SIZE ON PREDICTED DTFS GASIFICATION EFFICIENCIES OF VARIOUS CHARS AT $2650^{\circ} \mathrm{F}$ GAS TEMPERATURE 
Results presented in Figures 5-3a through 5-4 show that temperature, and carbon dioxide partial pressure and particle size play very important roles during char gasification. However, one thing is evident: None of these reaction parameters improves the performance of the low reactivity PSC char in the DTFS to a point where substantial increases in carbon conversions can be achieved in a single pass. A good combination of the same reaction parameters would lead to a very high performance of JRC char (close to complete gasification). These results indicate that the nature of the parent coal is very important and that empirical data are required to determine gasification rates for any particular coal.

\section{Coal Gasification}

Gasification reaction kinetic parameters obtained from this study were also used to predict the gasification performances of JRC, ILC, and PSC coals under specific conditions.

It is assumed that volatiles are released instantly and char gasification starts thereafter. The quantity of volatiles released in each case is equal to the DTFS weight loss obtained at 16-inch reaction zone during coal pyrolysis in nitrogen at $2650^{\circ} \mathrm{F}\left(\mathrm{VM}_{16}, \%\right.$ dry-ash-free basis) (Table 4-7). As such, predicted coal gasification efficiency $\left(\eta_{C}\right)$ is obtained as follows:

$$
\eta_{C}=V_{16}+\left(1-V M_{16} / 100\right) \eta
$$

where $\eta$ is the char gasification efficiency predicted by the model described in Appendix D. Eq. (5-1) indicates that $\eta_{C}$ is the total solid conversion to gas phase by both pyrolysis and gasification processes. Note that if char, instead of coal, were the starting material, $\mathrm{VM}_{16} \sim 0$, and Eq. $(5-1)$ reduces to $\eta_{c} \sim n$.

Figure 5-6 shows results on the predicted gasification efficiencies of $70 \%-200$ mesh fractions of JRC, ILC, and PSC coals at an isothermal gas temperature of $2600^{\circ} \mathrm{F}$ and constant $\mathrm{CO}_{2}$ partial pressure of 0.15 atmosphere. The gasification efficiencies $\left(\eta_{C}\right)$ of JRC, ILC, and PSC coals after a two-second residence time are 94,71 , and $63 \%$, respectively, indicating the great influence of fuel property effects.

Figure 5-7 shows the effects of temperature, particle size, and $\mathrm{CO}_{2}$ partial pressure $\left(\mathrm{P}_{2}\right)$ on the gasification efficiency of PSC coal. To examine the effect of temperature, $\mathrm{CO}_{2}$ partial pressure is maintained constant at 0.15 atmosphere, a $70 \%-200$ mesh is used, and temperature is varied from $2200^{\circ} \mathrm{F}$ to $3200^{\circ} \mathrm{F}$. The 


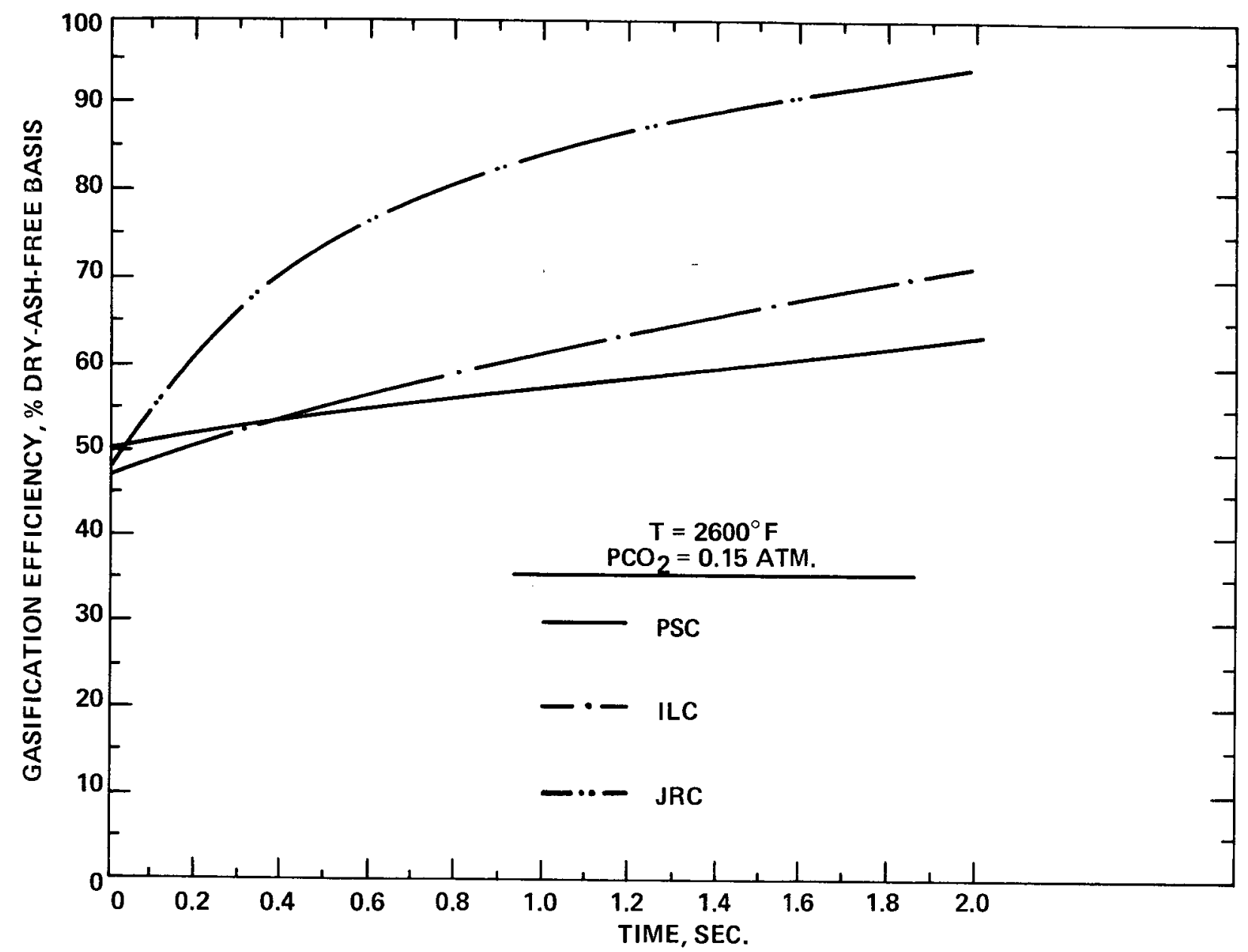

Figure 5-6 EFFECT OF FUEL TYPE ON PREDICTED DTFS GASIFICATION EFFICIENCIES OF 70\% - 200 MESH COALS 


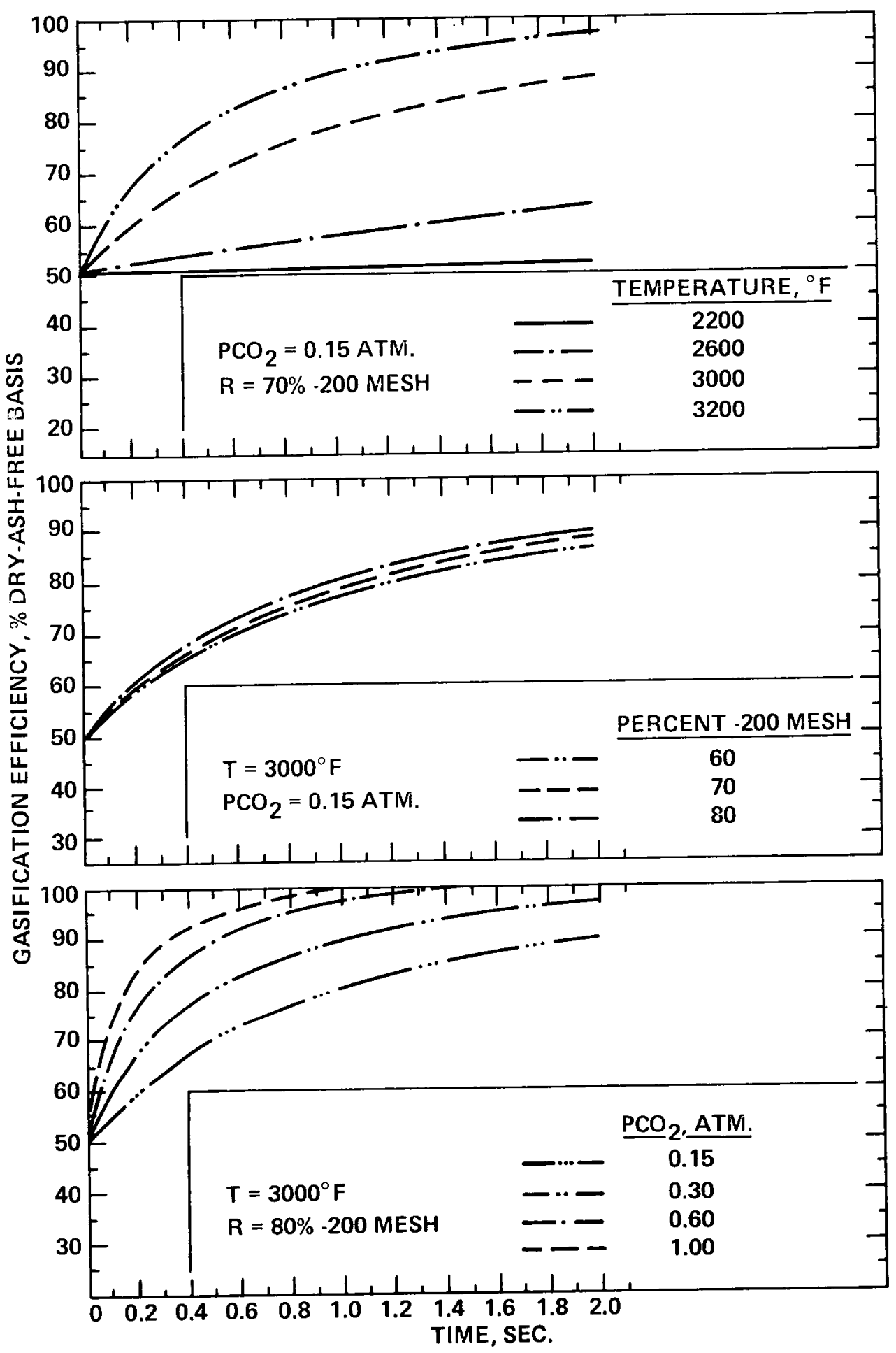

Figure 5.7 EFFECTS OF TEMPERATURE, PARTICLE SIZE AND CARBON DIOXIDE PARTIAL PRESSURE ON PREDICTED DTFS GASIFICATION EFFICIENCIES OF PSC COAL 
gasification efficiencies at two-second residence time are $52,63,88$, and $97 \%$, respectively, for $2200,2600,3000$, and $3200^{\circ} \mathrm{F}$ gas temperatures, indicating its substantial effect.

The effect of particle size on the gasification efficiency of PSC coal is examined by maintaining the temperature at an isothermal value of $3000^{\circ} \mathrm{F}$, the partial pressure of $\mathrm{CO}_{2}$ constant at 0.15 atmosphere, and varying particle size distributions from 60 to $80 \%-200$ mesh. The effect of particle size, under prevailing conditions, is quite small. Coal gasification efficiencies at a two-second residenct time are 86,88 , and $89 \%$, respectively, for 60,70 , and $80 \%-200$ mesh size distributions.

The effect of $\mathrm{CO}_{2}$ partial pressure on the gasification efficiency of PSC coal is examined by maintaining the temperature at $3000^{\circ} \mathrm{F}$, using a size grade of $80 \%-200$ mesh, and varying the partial pressure from 0.15 to 1.0 atmosphere. Under these conditions, coal gasification efficiency goes to completion in 1.4 seconds at carbon dioxide partial pressure of one atmosphere. At this time, the coal gasification efficiencies are 85,94 , and $99 \%$, respectively, for $\mathrm{CO}_{2}$ partial pressure of $0.15,0.30$, and 0.60 atmospheres. The corresponding values at two-second residence time are 90,97 , and $100 \%$. Although this particular parametric study is carried out at a very high temperature using very fine particles, $\mathrm{CO}_{2}$ partial pressure still exerts a strong influence on the PSC gasification efficiency.

Equation (5-1) makes a simplifying assumption that volatile matter $\left(\mathrm{VM}_{16}\right)$ released by pyrolysis does not react. In actuality, pyrogenic species $\mathrm{CH}_{2} \mathrm{O}, \mathrm{CO}_{2}, \mathrm{CO}, \mathrm{H}_{2}$, $\mathrm{CH}_{4}$, etc.) react homogeneously and heterogeneously. For example, $\mathrm{CO}_{2}$ and $\mathrm{H}_{2} \mathrm{O}$ react heterogeneously with carbon in the char to produce $\mathrm{CO}$ and $\mathrm{H}_{2}$. Therefore, the ultimate quantity and quality of product gas during coal gasification depends on the extents of both coal pyrolysis and char gasification. As such, the results obtained by Eq. (5-1) are not absolute values. They, instead, indicate gasification efficiency trends as a function of study parameters.

The above results indicate that temperature, fuel properties, and carbon dioxide partial pressure have significant effects on the extent of coal gasification. They further indicate that because of the low gasification reactivity of the Pittsburgh No. 8 coal, significant overall gasification can only occur if extremely high temperatures $\left(3000^{\circ} \mathrm{F}\right)$ and high carbon dioxide partial pressure $(0.6 \mathrm{~atm}$ ) are sustained for long residence times ( 2 seconds). Therefore, a relatively large contribution to product gas heating values will be due to devolatilization because of the low char reactivity of the Pittsburgh coal as it is gasified. 
Section 6

REFERENCES

1. Brunauer, S., Emmett, P. H., and Teller, E., "Adsorption of Gases in Multilayers," J. Am. Chem, Soc., 60 , 309 (1938).

2. Gregg, S. J., and Sing, K. S. W., "Adsorption, Surface Area and Porosity, "Academic Press, London and New York, Second Printing, 1969, p. 223.

3. Patterson, R. C., and Darling, S. L., "A Low-Btu Coal Gasification System," Combustion Engineering Power Systems Publication TIS-6299, Presented at 72nd Annual Meeting of the American Institute of Chemical Engineers in San Francisco, CA, November 25-29, 1979.

4. Darling, S. L., Koucky, R. W., and Tanca, M. C., "PDU Comprehensive Report," DOE Technical Report FE-1545-91 under DOE Contract No. DE-AC01-76ET10204, June, 1982.

5. Wen, C. Y., and Chuang, T. Z., "Entrained-Bed Coal Gasification Modelling," Interim Report FE-2274-T1 Submitted to the US Department of Energy, 1978.

6. Dobner, S., "Modelling of Entrained-Bed Gasification: The Issues," Electric Power Research Institute, Palo Alto, CA, January 15, 1976.

7. Gray, M. D., and Kimber, G. M., "Reaction of Charcoal Particles with Carbon Dioxide and Water at Temperatures up to $2800^{\circ} \mathrm{K}, "$ Nature, 214, 797 (1967).

8. Knight, A. T., and Sergeant, G. D., "Reactivity of Australian Coal-Derived Chars to Carbon Dioxide," Fue1, 61, 145 (1981).

9. Field, M. A., Gill, D. W., Morgan, B. B., and Hawksley, P. G. W., "Isothermal Combustion of a Suspension of Coal Particles in Plug Flow," Combustion of Pulverized Coal, BCURA, Leatherhead, England, 1967, p. 211.

10. Field, M. A., "Rate of Combustion of Size-Graded Fractions of Char from a Low Rank Coal Between $1200^{\circ} \mathrm{K}$ and $2000^{\circ} \mathrm{K}$, "Combustion and Flame, 13, 237 (1969).

11. Field, M. A., "Measurements of the Effect of Rank on Combustion Rates of Pulverized Coal," Combustion and Flame, 14, 237 (1970).

12. Badzioch, S., and Hawksley, P. G. W., "Kinetics of Thermal Decomposition of Pulverized Coal Particles," In. Eng. Chem. Process Des. Develop., 9, 521 (1970).

13. Nsakala, N., Essenhigh, R. H., and Walker, P. L., Jr., "Studies on Coal Reactivity: Kinetics of Lignite Pyrolysis in Nitrogen at $808^{\circ} \mathrm{C}$, " Combustion Science and Technology, 16, 153 (1977). 
14. Hawksley, P. G. W., Badzioch, S., and Blackett, J. H., "Terminal Velocities of Particles," Measurement of Solids in Flue Gases, BCURA, Leatherhead, England, 1961, p. 181.

15. Davies, C. N., "Definitive Equations for the Fluid Resistance of Spheres," Proc. Phys. Soc., London, 57, 259 (1945).

16. Nsakala, N., "Characteristics of Chars Produced by Pyrolysis Following Rapid Heating of Pulverized Coal," PhD Thesis, The Pennsylvania State University, University Park, PA, November 1976.

17. Field, M. A., Gill, D. W., Morgan, B. B., and Hawksley, P. G. W., "The Fineness of Pulverized Fuel, "Combustion of Pulverized Coal, BCURA, Leatherhead, England, 1967, p. 245.

18. Walker, P. L., Jr., and Kini, K. A., "Measurement of U1trafine Areas of Coals," Fuel, 44, 463 (1965).

19. Walker, P. L., Jr., Rusinko, F., Jr., and Austin, L. G., "Gas Reactions of Carbon," Advances in Catalysis, Vol. 11, Academic Press, Inc., New York and London, 1959, p. 133.

20. Wen, C. Y., Galli, A. F., and Sears, J. T., "The Role of the Char-CO, Reaction in Coal Gasification, "Final Report FE-0497-T9 Submitted to the US Department of Energy, 1980. 
APPENDIX A

TEST FACILITIES

Al1 the major test facilities used throughout this investigation are described below.

\section{FLAMMABILITY INDEX APPARATUS}

The Flammability Index Apparatus (Figure A-1) is a device used to determine the ignition temperatures of pulverized solid fuels under specific conditions. This apparatus was employed to measure the relative ignition temperatures of coals. About $0.2 \mathrm{~g}$ of sample sized to $200 \times 0$ mesh is placed in the sample holder. The furnace is preheated to a desired level, then the solenoid-operated valve is opened, allowing oxygen from a $2-1$ iter storage reservoir to suspend and convey the sample through the furnace. If ignition does not occur, the procedure is repeated at higher temperatures, in $50^{\circ} \mathrm{F}$ increments, until ignition occurs. If ignition does occur in the first trial, then the procedure is repeated to determine the temperature below which ignition does not occur. In either case, fine tuning is necessary to further narrow the error margin. This ignition temperature is called the Flammability Index. The value of the Flammability Index compared to other fuels indicates the flame ignition temperature/stability on a relative basis.

\section{TGS-2 THERMO-GRAVIMETRIC ANALYSIS SYSTEM}

The Perkin-Elmer Model TGS-2 is a complete, second-generation system for accurately recording the weight loss or weight gain or rate of weight change of a sample as it is subjected to a precisely controlled temperature environment. It is a completely modular system consisting of the following independently packaged units: the Thermobalance Analyzer, the Electronic Balance Control, the Temperature (program) Microprocessor Controller, the Heater Control Unit, the First Derivative Computer (FDC), and the Recorder.

This apparatus uses a small solid sample to determine either its micro-proximate analysis using the general procedure established by the American Society for 


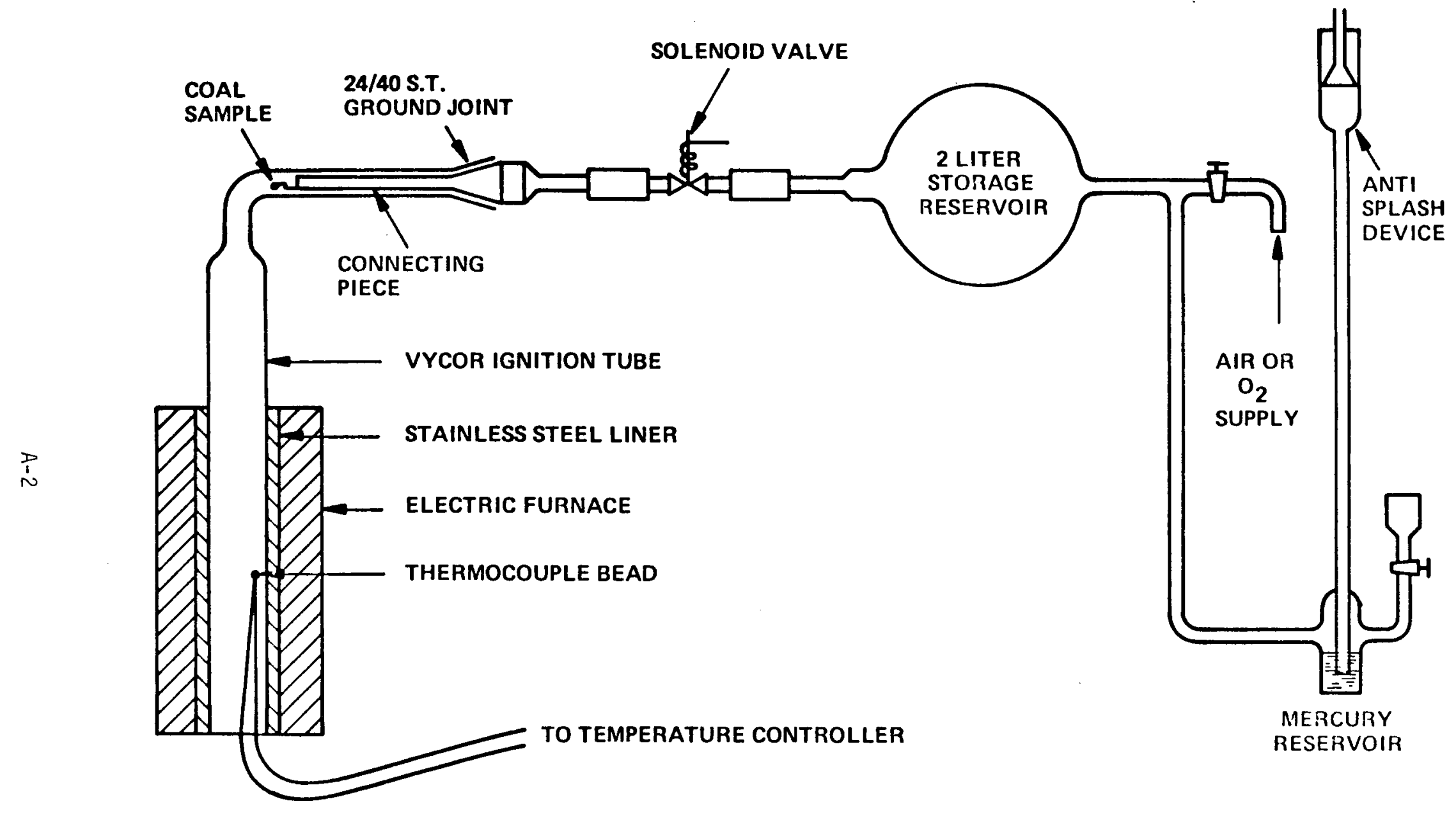

Figure A-1 SCHEMATIC OF FLAMMABILITY APPARATUS 
Testing Materials (ASTM) or its thermo-gravimetric reactivity under specific experimental conditions (heating rate, reaction medium, and reaction temperature).

The micro-proximate analysis is determined as follows. A 4-6 $\mathrm{mg}$ sample is purged with nitrogen to remove oxygen traces. The moisture loss is obtained by heating in nitrogen to $105^{\circ} \mathrm{C}$ and holding for three minutes. Subsequently, the sample is heated at $100^{\circ} \mathrm{C} / \mathrm{min}$ to $950^{\circ} \mathrm{C}$ and held at this temperature for five minutes to obtain volatile matter. After this, the temperature is lowered to $750^{\circ} \mathrm{C}$ and a switching valve is used to introduce oxygen for the combustion of fixed carbon at this temperature. The residue represents the ash content.

The isothermal char reactivity test is determined as follows. A 4-6 $\mathrm{mg}$ sample of specific size grade is placed in the TGS-2 System and heated in the presence of nitrogen at $20^{\circ} \mathrm{C} / \mathrm{min}$ to the reactivity temperature $\left(700^{\circ} \mathrm{C}\right.$ for combustion and $950^{\circ} \mathrm{C}$ for gasification). After stabilization at this temperature, the reaction medium (air for combustion and carbon dioxide for gasification) is introduced. The percent weight of the unburned or ungasified char and rate of weight loss are recorded on a strip chart as a function of time. These thermo-grams are subsequently used to determine the char combustion or gasification efficiency history and reactivity parameter (which indicates the maximum rate of weight loss per unit weight of the original sample in the TGS-2 System).

\section{QUANTASORB SURFACE AREA ANALYZER}

The principle of operation of the Quantasorb Surface Area Analyzer involves passing a mixture of helium (used as a carrier) and adsorbate $\left(\mathrm{N}_{2}\right.$ or $\left.\mathrm{CO}_{2}\right)$ through a U-shaped small cell containing the smaple.* The amount of adsorbate physically adsorbed at various partial pressures on the sample (adsorbent) surface can then be used to calculate the sample's surface area.

Adsorption and desorption occur when the sample is immersed into and then withdrawn from the liquid controlling the adsorption temperature. Liquid nitrogen and room temperature $\left(25^{\circ} \mathrm{C}\right)$ water are used for nitrogen adsorption and desorption, respectively. Room temperature and hot $\left(60^{\circ} \mathrm{C}\right)$ water are used for carbon dioxide

* Outgassed in the Quantasorb at $200^{\circ} \mathrm{C}$ and one hour using nitrogen as the sweeping gas. 
adsorption and desorption, respectively. Changes in the ratio of helium to adsorbate in the flowing stream, due to adsorption and desorption, are sensed by a specially designed thermal conductivity detector. The signals delivered by the detector are nearly Gaussian in shape. The instantaneous signal height is proportional to the rate of adsorption or desorption and the total integrated area under the curve is proportional to the quantity of gas adsorbed. As such, the function of the Quantasorb Surface Analyzer is to measure the quantity of gas adsorbed at a given temperature and partial pressure.

A BET (Brunauer, Emmett, Teller) single point method is used in conjunction with $\mathrm{N}_{2}$ adsorption at $-196^{\circ} \mathrm{C}\left(-321^{\circ} \mathrm{F}\right)$ to determine the sample's BET specific surface area (1). A Dubinin-Kaganer method is used in conjunction with $\mathrm{CO}_{2}$ adsorption at $25^{\circ} \mathrm{C}\left(77^{\circ} \mathrm{F}\right)$ to determine the sample's $\mathrm{CO}_{2}$ specific surface area (2).

DROP TUBE FURNACE SYSTEM (DTFS)

The Drop Tube Furnace System (Figure A-2) is comprised of a 1-inch inner diameter horizontal tube gas preheater and a 2-inch inner diameter vertical tube test furnace for providing controlled temperature conditions. Both tubes are electrically heated with silicon carbide elements $(\mathrm{SiC})$ and are rated at $2800^{\circ} \mathrm{F}$. The DTFS was used to study pyrolysis, combustion, and gasification of coals and/or chars.

The principle of operation of the DTFS is as follows. Size graded fuel $(0.055-$ $0.095 \mathrm{gm} / \mathrm{min}$ ) is introduced with a small amount of carrier gas into the hot reaction zone of the test furnace through a water-cooled fuel injector. A preheated secondary gas stream is introduced around the primary stream. Injection of fuel particles into the hot gas stream results in a rapid heating of the particles to the prevailing gas temperature (at a rate of the order of $10^{4}{ }^{\circ} \mathrm{C} / \mathrm{sec}$ ). Following the rapid heating period, pyrolysis, gasification, and/or combustion of particles occur for a specific time. Then all reactions are rapidly quenched. Solid products are separated from the gaseous products in a small filter housing, and an aliquot of the effluent gas sample is sent to a pre-calibrated Gas Analysis System.

The solid products collected at various locations along the axis of the DTFS reaction zone can be analyzed to determine solid conversion efficiencies. An ash tracer method, which is based on the assumption that ash remains inert during 


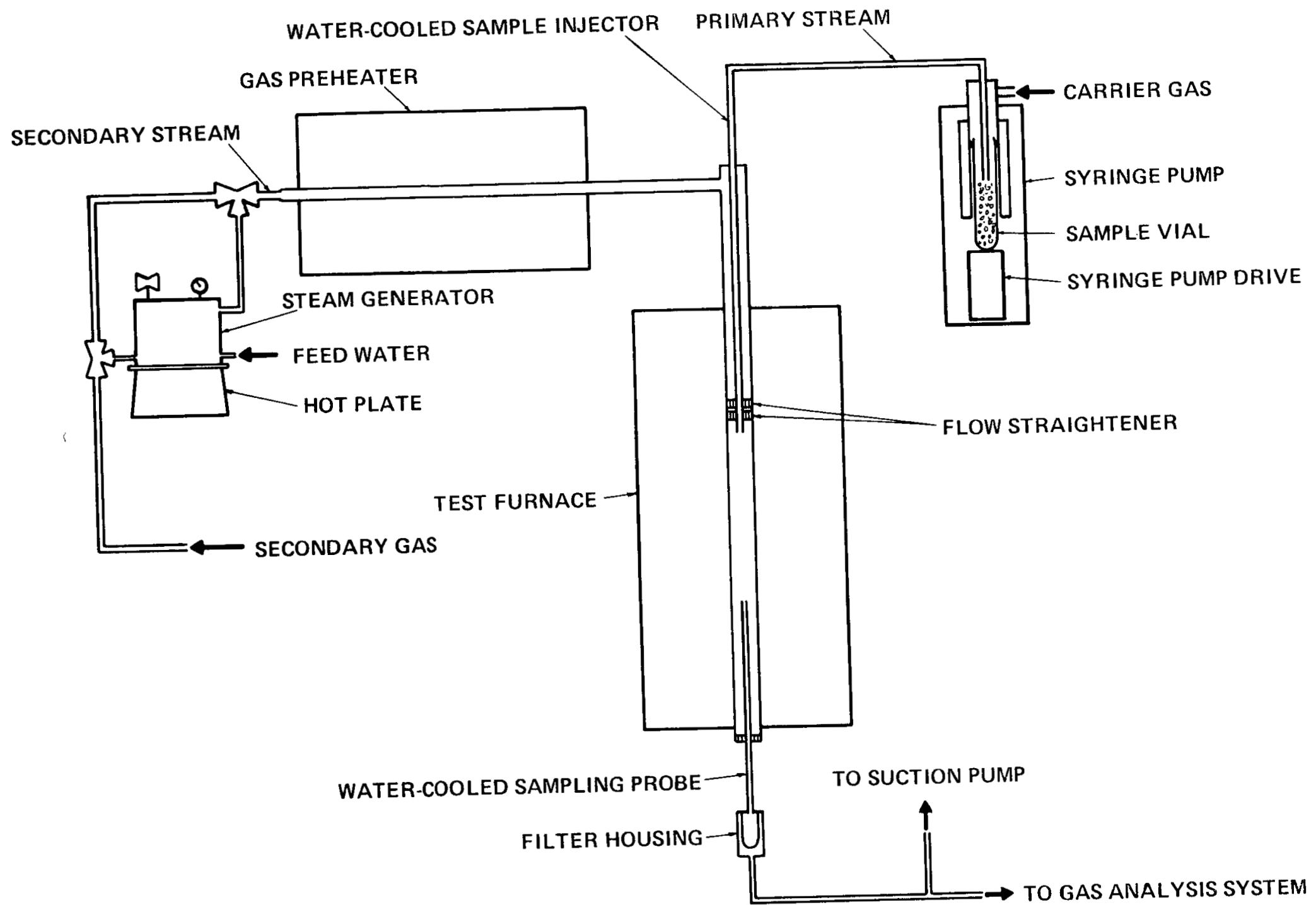

FIGURE A-2 SCHEMATIC OF THE COMBUSTION ENGINEERING DROP TUBE FURNACE SYSTEM 
either pyrolysis or combustion, is used to calculate the fuels' pyrolys is or combustion efficiency. The aliquot of the effluent gas sample is analyzed on-tine to determine $\mathrm{NO}_{\mathrm{X}}, \mathrm{O}_{2}, \mathrm{CO}$, and $\mathrm{CO}_{2}$ concentrations. Carbon monoxide (CO) is used to determine carbon gasification efficiency in carbon dioxide and steam. 
APPENDIX B

REACTION KINETIC PARAMETER DETERMINATIONS

Char combustion or gasification kinetic parameters were determined on the basis of Field's formulation given below (10, 11 ).

OVERALL REACTION RATE COEFFICIENT

The overall reaction rate coefficient $(K)$ is defined as the rate of carbon removal per unit external surface area per unit atmosphere partial pressure of oxygen in gas (for combustion) or carbon dioxide in gas (for gasification). That is

$$
K=q / P_{g}
$$

where $q$ is the rate of carbon removal per unit external surface area $\left(\mathrm{g} \mathrm{cm}^{-2} \mathrm{sec}^{-1}\right)$, and $\mathrm{P}_{\mathrm{g}}$ is the partial pressure of oxygen or carbon dioxide in the gas (atm.).

Reaction rate, $q$, is given by

$$
q=(1 / t) \oint_{0}^{B}(1 / s) d B
$$

where $S$ is the surface area at burn-off or gasification-level B per unit weight of moisture and ash-free char, and $t$ is the residence time in the reaction zone. $S$ is given by

$$
S=6 U / X_{\rho}
$$

where $U=1-B$ is the fraction of combustible or gasifiable char remaining unburnt or ungasified, $X$ is the mean weight particle diameter $(\mathrm{cm})$, and $\rho$ is the apparent density of char $\left(\mathrm{g} / \mathrm{cm}^{3}\right.$, dry-ash-free $)$.

Field found the following variation of surface area with burn-off for a non-swelling coal assuming a shrinking core mechanism

$$
s / s_{0}=u^{2 / 3}
$$


where $S_{0}$ is the geometric surface area of the feed char. It was reasonable to use Eq. (B-4) in the present work since: (1) the chars were non-swelling, and (2) it could be assumed on the basis of experimental data given in Tables 4-8 and 4-12 that both char combustion and gasification proceeded by a shrinking core mechanism.

Combining Eqs. $(B-2)$ and $(B-4)$ yields

$$
q=(1 / t) \int_{1}^{U}\left(-1 /\left(s_{0} u^{2 / 3}\right)\right) d U
$$

which, upon integrating between the limits, leads to

$$
q=3\left(1-u^{1 / 3}\right) / s_{0} t
$$

Substituting $q$ in Eq. (B-1) from Eq. $(B-6)$ yields

$$
K=3\left(1-U^{1 / 3}\right) /\left(S_{o} t P_{g}\right)
$$

DIFFUSIONAL REACTION RATE COEFFICIENT

Diffusional reaction rate coefficient $\left(K_{D I F F}\right)$ is given by

$$
K_{D I F F}=24 \emptyset D / \bar{X} R^{\prime} T
$$

where $D$ is the diffusion coefficient of oxygen or carbon dioxide through the carrier gas $\left(\mathrm{cm}^{2} / \mathrm{sec}.\right), \bar{X}$ is the mean weight particle diameter $(\mathrm{cm}), R^{\prime}$ is the gas constant $\left(82.06 \mathrm{~atm} . \mathrm{cm}^{3} / \mathrm{mole}^{\circ} \mathrm{K}\right), T$ is the gas temperature in the boundary layer $\left({ }^{\circ} \mathrm{K}\right.$ ), and $\emptyset$ is the mechanism factor (defined as the ratio of moles of carbon consumed to moles of reactant gas transported to the surface). Values of $\emptyset$ equal to 2 and 1 were used for char combustion and gasification, respectively.

\section{SURFACE REACTION RATE COEFFICIENT}

The overal1 reaction rate coefficient $(K)$ is dependent both on the rate of transport of oxygen or carbon dioxide by diffusion to the particle surface $\left(K_{D I F F}\right)$ and the rate of reaction of oxygen or carbon dioxide at the particle surface $\left(K_{S}\right)$. This is represented mathematically as

$$
1 / K=1 / K_{\text {DIFF }}+1 / K_{S}
$$


Eq. (B-9) can be rearranged to

$$
K_{S}=K K_{D I F F} /\left(K_{D I F F}-K\right)
$$

Eq. (B-10) was used throughout this work to calculate surface reaction rate coefficients during char combustion or gasification.

\section{APPARENT ACTIVATION ENERGY AND FREQUENCY FACTOR}

The Arrhenius relation was used in conjunction with Eq. (B-10) to calculate the apparent activation energy $(E)$ and frequency factor $(A)$ for char combustion or gasification. That is

$$
K_{S}=A \exp (-E / R T)
$$

The values of $E$ and $A$ in $E q$. ( $B-11)$ were determined for each char combustion or gasification from the slope and intercept of the least squares fits of in $K_{S} v s$. $1 / T$ plot. Results obtained from this work are illustrated in Section 4. 
APPENDIX C

SUMMARY OF DROP TUBE FURNACE SYSTEM (DTFS) TEST DATA

The computer printouts presented in this Appendix summarize the DTFS test data. Terms which may not be obvious are explained as follows:

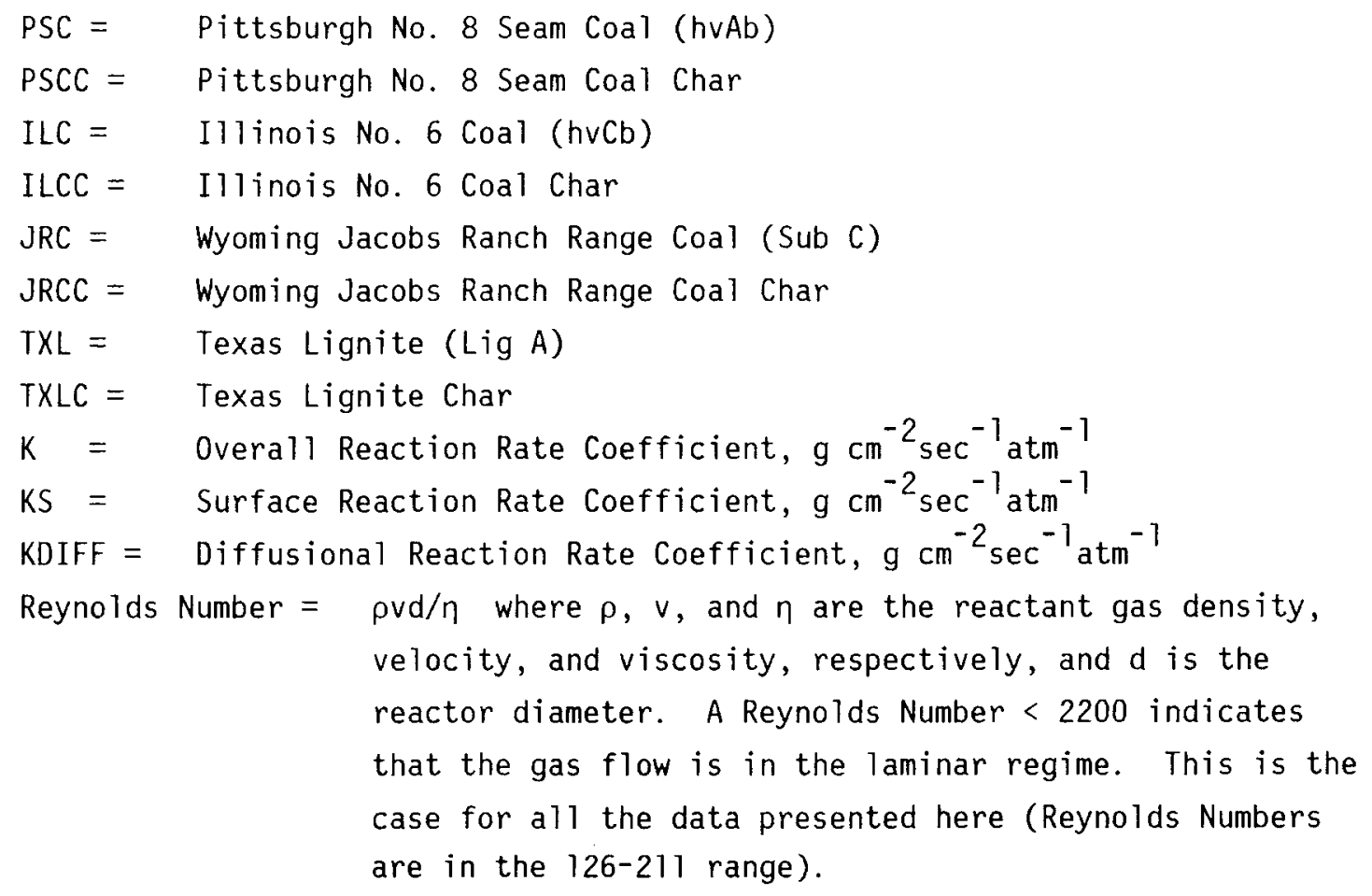

Notes: 1. Combustion data start on p. C-2.

2. Gasification data start on p. c-13.

3. The values of K/DIFF approaching unity indicate a diffusion-controlled phenomenon. All K/DIFF $>0.7$ were deleted when calculating surface reaction rate coefficients (KS). 
JROP IUBE FURVACE SYSTEM DATA REDUCTION PROGRAM

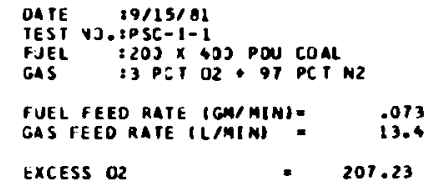

\begin{tabular}{|c|c|c|c|c|c|c|c|}
\hline $\begin{array}{l}\text { DISIANCE } \\
\text { IINCHESI }\end{array}$ & $\begin{array}{l}\text { TEMPERA IURE } \\
\text { IDEG FI }\end{array}$ & $\begin{array}{l}\text { MOI S TURE } \\
\text { IN CHAR } \\
\text { IPCT I }\end{array}$ & $\begin{array}{l}\text { ASH IN } \\
\text { CHAR } \\
\text { (PCT) }\end{array}$ & $\underset{(P P Y)}{\operatorname{Nox}}$ & $\begin{array}{c}02 \\
(P C T)\end{array}$ & $\underset{(P C T)}{C O 2}$ & $\underset{\text { (PPM) }}{C O}$ \\
\hline $\begin{array}{r}1.0 \\
2.0 \\
4.0 \\
8.0 \\
12.0 \\
16.0\end{array}$ & $\begin{array}{l}1738 . \\
1769 . \\
1776 . \\
1803 . \\
1806 . \\
1804 .\end{array}$ & $\begin{array}{l}2.2 \\
1.9 \\
2.1 \\
2.4 \\
2.2 \\
1.0\end{array}$ & $\begin{array}{l}15.2 \\
16.0 \\
10.7 \\
18.0 \\
16.8 \\
21.2\end{array}$ & $\begin{array}{l}55 . \\
23 . \\
10 . \\
73 . \\
48 . \\
85 .\end{array}$ & $\begin{array}{l}2.400 \\
2.800 \\
3.130 \\
2.300 \\
2.300 \\
2.200\end{array}$ & $\begin{array}{r}.720 \\
.480 \\
.120 \\
.900 \\
.780 \\
1.080\end{array}$ & $\begin{array}{r}3600 . \\
2700 . \\
660 . \\
160 . \\
40 . \\
40 .\end{array}$ \\
\hline
\end{tabular}

\begin{tabular}{|c|c|c|c|c|c|c|}
\hline $\begin{array}{l}\text { DISIAYCE } \\
\text { (IVCHES) }\end{array}$ & $\begin{array}{l}\text { TEMPERA TURE } \\
\text { (DEG F) }\end{array}$ & $\begin{array}{l}\text { IIME } \\
\text { ISEC.) }\end{array}$ & $\begin{array}{l}\text { CONYERSIJH } \\
\text { EFFICIENCY } \\
\text { (aY ASH IRACES) } \\
\text { (PCI) }\end{array}$ & $\begin{array}{l}\text { PAR TICLE } \\
\text { (FREE-FALL) } \\
\text { VELOCITY } \\
\text { (CM.IS }\end{array}$ & $\begin{array}{l}\text { GAS } \\
\text { YELOCITY } \\
\text { SEC. I }\end{array}$ & $\begin{array}{l}\text { REYMOLO } \\
\text { NUMBER }\end{array}$ \\
\hline $\begin{array}{r}1.0 \\
2.0 \\
4.0 \\
8.0 \\
12.0 \\
16.0\end{array}$ & $\begin{array}{l}1738 . \\
1769 . \\
1716 . \\
1803 . \\
1806 . \\
1804 .\end{array}$ & $\begin{array}{l}.050 \\
.101 \\
.200 \\
.397 \\
.593 \\
.709\end{array}$ & $\begin{array}{l}47.6 \\
50.6 \\
21.5 \\
57.5 \\
53.5 \\
64.6\end{array}$ & $\begin{array}{l}4.69 \\
4.68 \\
4.65 \\
4.62 \\
4.62 \\
4.62\end{array}$ & $\begin{array}{l}45.72 \\
45.94 \\
46.50 \\
47.06 \\
47.13 \\
47.09\end{array}$ & $\begin{array}{l}160 . \\
160 . \\
139 . \\
158 . \\
158 . \\
158 .\end{array}$ \\
\hline
\end{tabular}

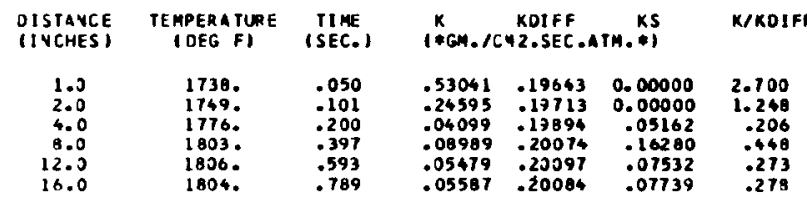

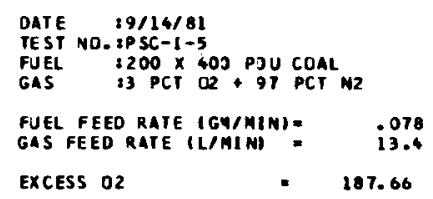

\begin{tabular}{|c|c|c|c|c|c|c|c|}
\hline $\begin{array}{l}\text { PISTAYCE } \\
\text { IIVCHESI }\end{array}$ & $\begin{array}{l}\text { TEMPERA TURE } \\
\text { (DEG F) }\end{array}$ & $\begin{array}{l}\text { MOISIURE } \\
\text { IN CHAR } \\
\text { (PCT) }\end{array}$ & $\begin{array}{l}\text { ASH IN } \\
\text { CHAR } \\
\text { (PCT) }\end{array}$ & $\begin{array}{l}\text { MOX } \\
\text { (P PM) }\end{array}$ & $\underbrace{02}_{(P C N)}$ & $\begin{array}{c}\mathrm{CO2} \\
(\mathrm{PC} \mathrm{T})\end{array}$ & $\operatorname{CO}_{(\mathrm{PPM})}$ \\
\hline $\begin{array}{r}1.0 \\
2.0 \\
4.0 \\
8.0 \\
12.0 \\
16.0\end{array}$ & $\begin{array}{l}23600^{\circ} \\
2410 . \\
26840^{\circ} \\
25620^{\circ} \\
26240^{\circ}\end{array}$ & $\begin{array}{r}1.2 \\
.9 \\
.9 \\
.7 \\
.6\end{array}$ & $\begin{array}{l}16.3 \\
17.3 \\
18.2 \\
19.9 \\
28.3 \\
39.0\end{array}$ & $\begin{array}{l}33 . \\
88 . \\
75 . \\
53 . \\
75 . \\
33 .\end{array}$ & $\begin{array}{l}2.850 \\
2.400 \\
2.250 \\
2.150 \\
1.900 \\
1.900\end{array}$ & $\begin{array}{r}.210 \\
.720 \\
.780 \\
.900 \\
1.800 \\
1.200\end{array}$ & $\begin{array}{r}2220 \\
2025 \\
160^{\circ} \\
150^{\circ} \\
160^{\circ} \\
40^{\circ}\end{array}$ \\
\hline
\end{tabular}

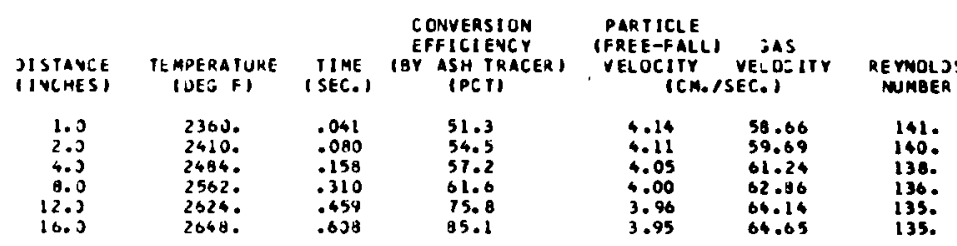

\begin{tabular}{|c|c|c|c|c|c|c|}
\hline $\begin{array}{l}\text { MISTAYCE } \\
\text { IINCHESI }\end{array}$ & $\begin{array}{l}\text { TEMPERA IURE } \\
\text { IUES FI }\end{array}$ & $\begin{array}{l}\text { TIME } \\
\text { ( SEC.) }\end{array}$ & $\stackrel{x}{10 G M .1:}$ & $\begin{array}{l}\text { KOIFF } \\
\text { M2.SEC.A }\end{array}$ & $\mid \begin{array}{r}k s \\
m .\end{array}$ & $\ll /<D I f$ \\
\hline $\begin{array}{r}1.0 \\
2.0 \\
6.0 \\
0.0 \\
22.3 \\
10.0\end{array}$ & $\begin{array}{l}2363 . \\
2610 . \\
2684 . \\
2562 . \\
2626 . \\
2568 .\end{array}$ & $\begin{array}{l}.041 \\
.040 \\
.158 \\
.310 \\
.459 \\
.6 .39\end{array}$ & $\begin{array}{l}.60968 \\
.39599 \\
.22932 \\
.13567 \\
.14308 \\
.13490\end{array}$ & $\begin{array}{l}.23680 \\
.23991 \\
.24456 \\
.26941 \\
.25321 \\
.25471\end{array}$ & $\begin{array}{r}0.00000 \\
0.00000 \\
3.87813 \\
.29746 \\
.32895 \\
.28681\end{array}$ & $\begin{array}{l}2.575 \\
1.551 \\
.938 \\
.544 \\
.505 \\
.530\end{array}$ \\
\hline
\end{tabular}


DRUP IUBE Furnace SYSIEM JATA REOUCTIOM PROGMAM

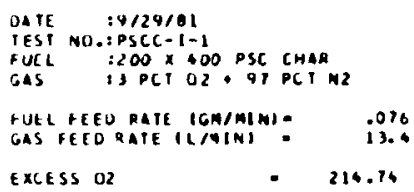




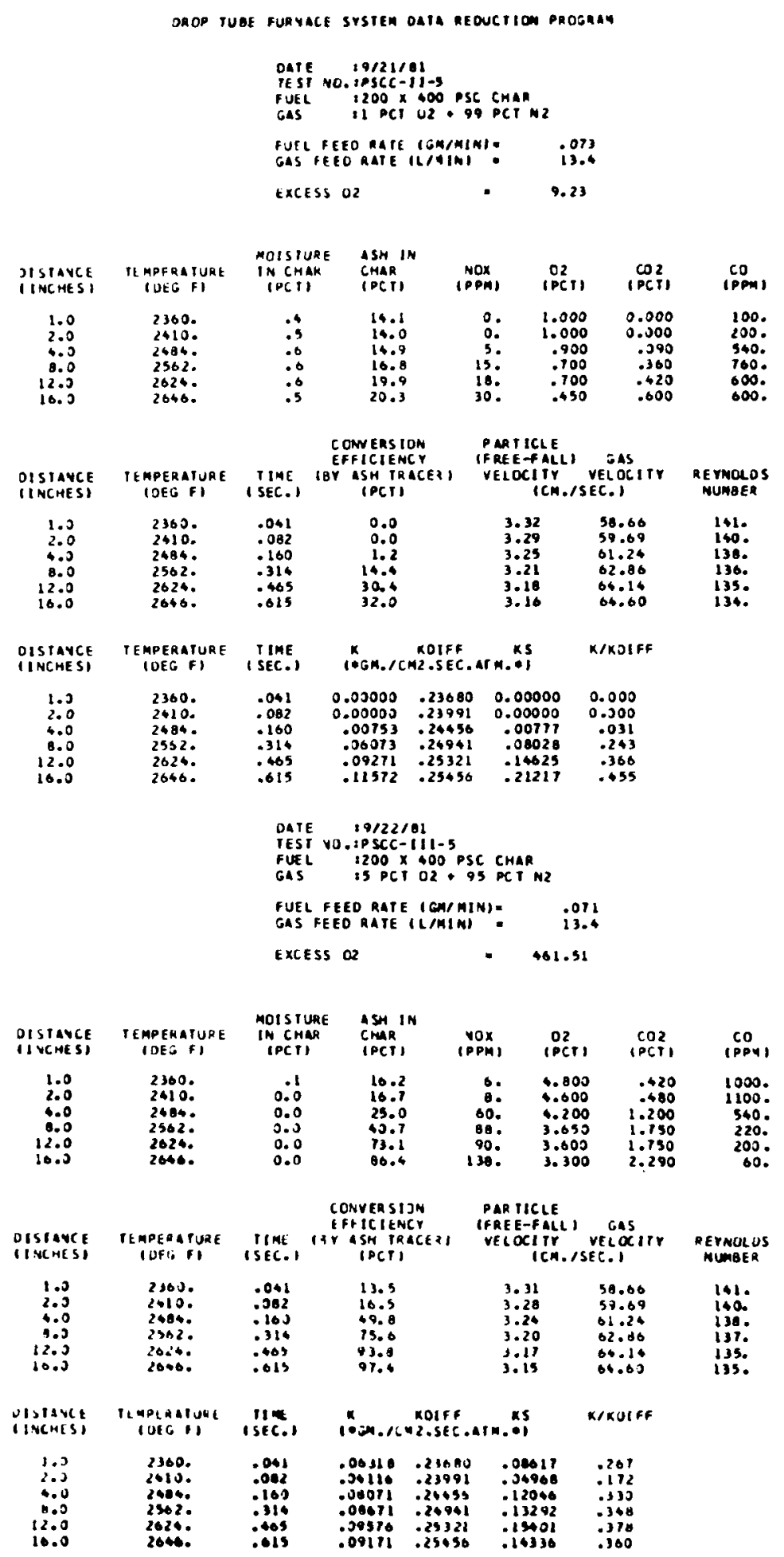


OROP TUBE FURAACE SYSTEM DATA REDUCTIOM PROGRAM

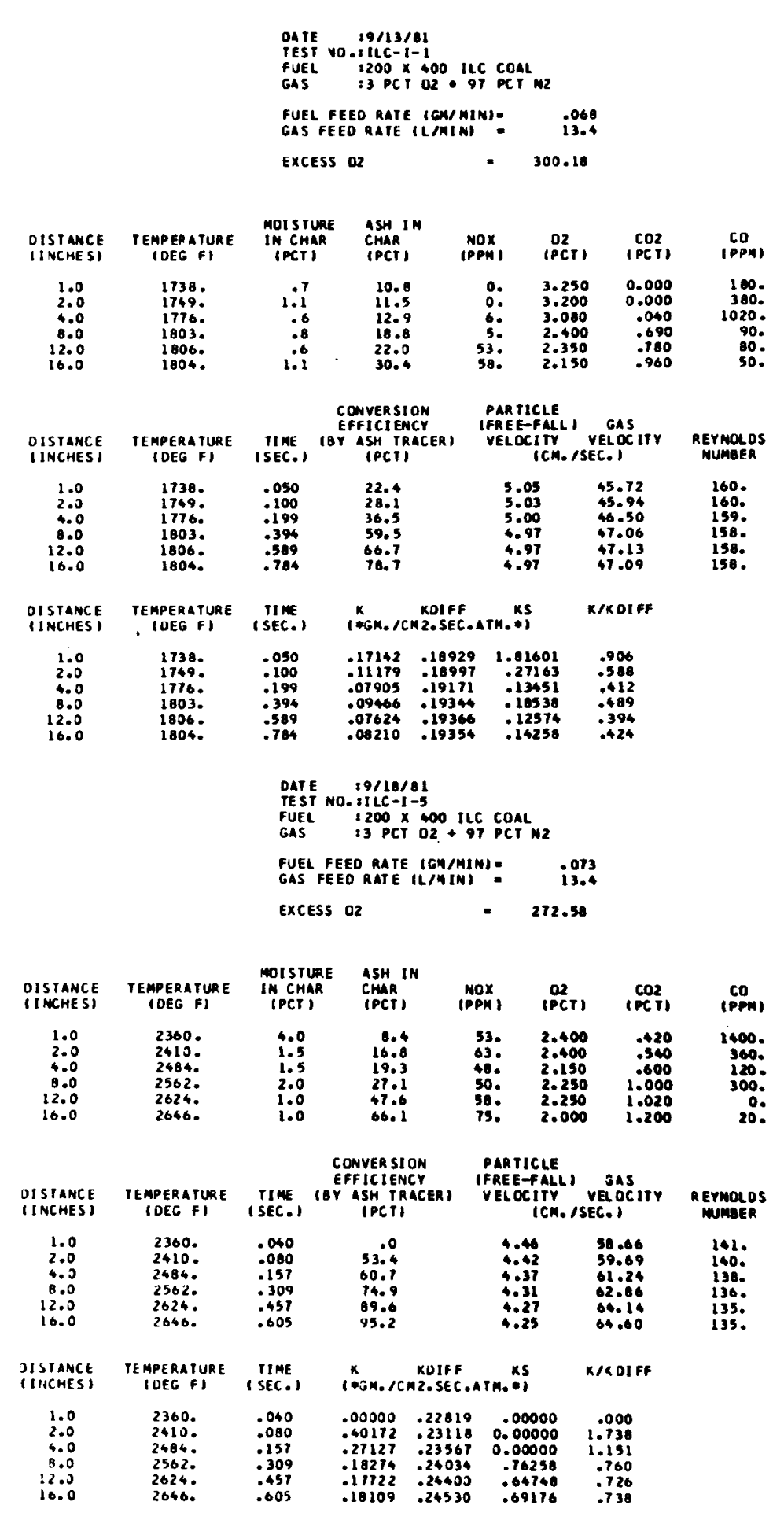


DROP TUBE FURNACE SYSTEM DATA REDUCTION PROGRAM

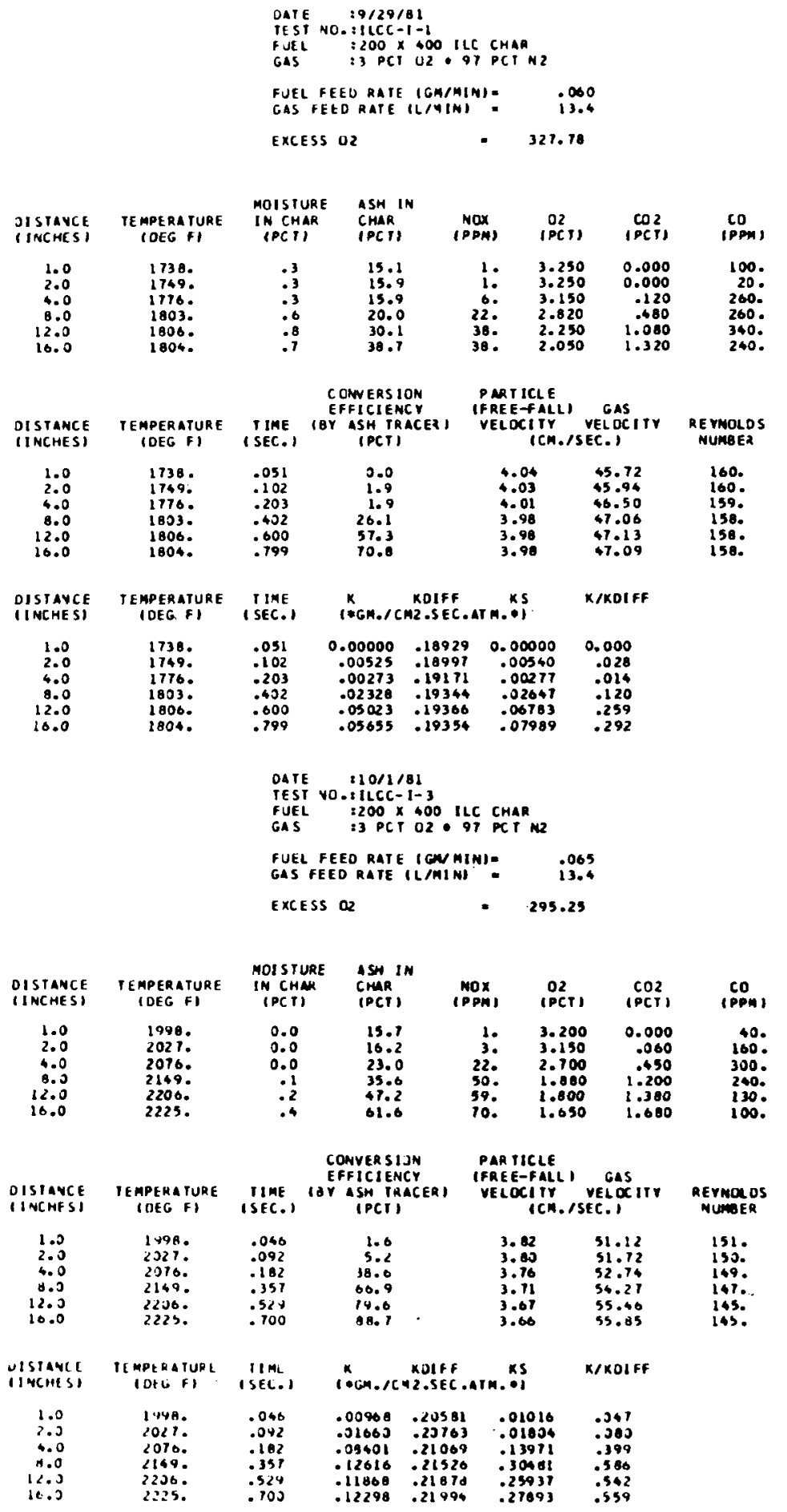


DROP TUBE FURNACE SYSTEM DATA REDUCTION PROGR MM

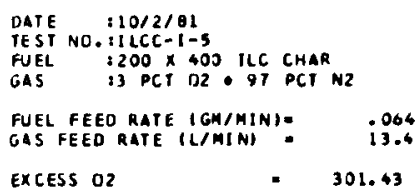


JROP IUBE FURMACE SYSTEM OATA REDUCTION PRUGRAY
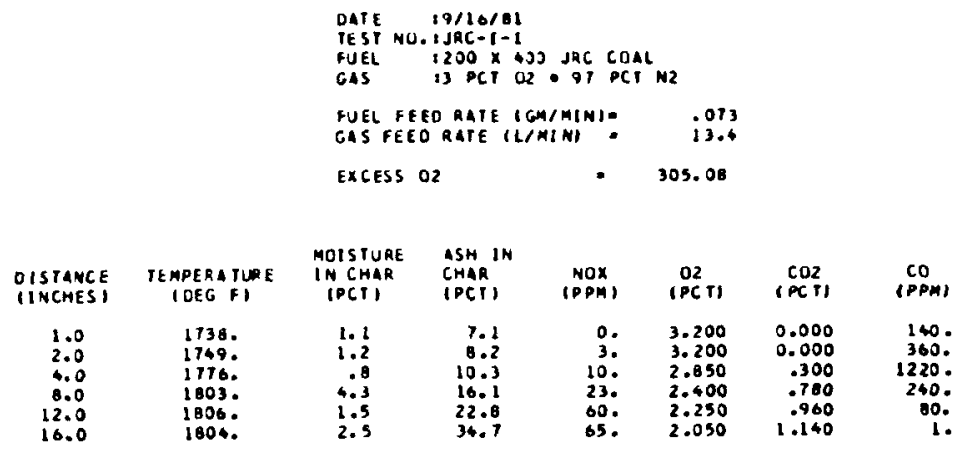

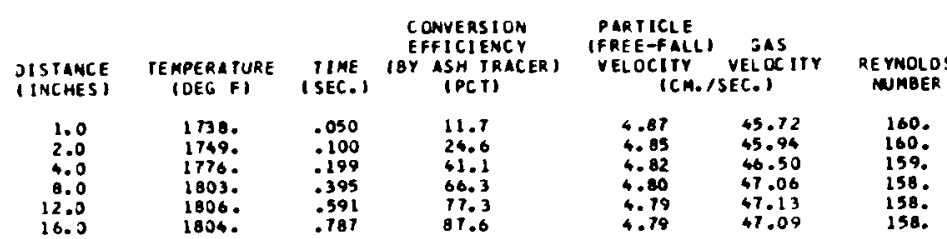

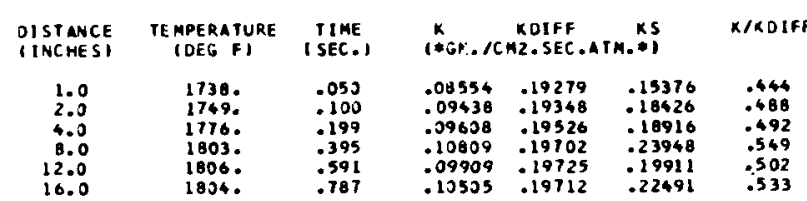

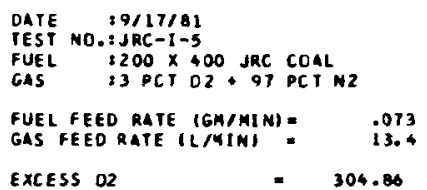

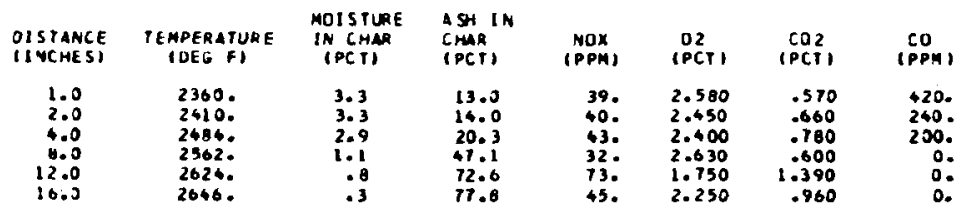

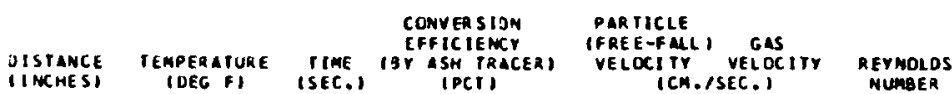

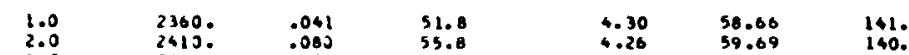

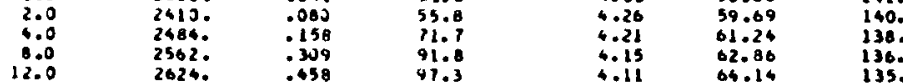

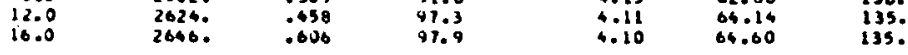

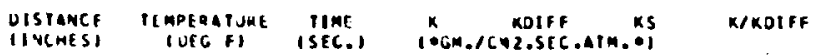

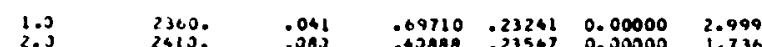

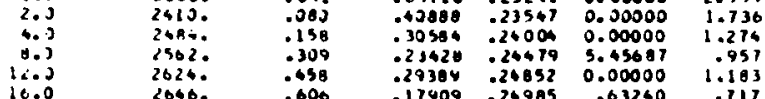


OROP TUEE FURNACE SYSTEM OATA REDCTION PROGRAM

$$
\begin{aligned}
& \text { OATE } 99 / 29 / 81 \\
& \text { GUEL :203X } 4 J 3 \text { JRE CHAR } \\
& \begin{array}{l}
\text { FUEL FEED RATE (GM/MIN)E } \\
\text { GASFEEDRATE (LMIN) }
\end{array} \\
& \text { EXCESS } 02 \\
& \text { - } 248.07
\end{aligned}
$$

\begin{tabular}{|c|c|c|c|c|c|c|c|c|c|c|}
\hline $\begin{array}{l}\text { DISTANCE } \\
\text { IINCHESI }\end{array}$ & $\begin{array}{l}\text { TEMPERATURE } \\
\text { IDEG FI }\end{array}$ & \multicolumn{2}{|c|}{$\begin{array}{l}\text { MOISTURE } \\
\text { IN CHAR } \\
\text { (PCT) }\end{array}$} & \multicolumn{2}{|c|}{$\begin{array}{l}\text { ASH IN } \\
\text { CHAR } \\
\text { (PCT) }\end{array}$} & \multicolumn{2}{|c|}{$\begin{array}{l}\text { NOX } \\
\text { (PPA) }\end{array}$} & \multicolumn{2}{|c|}{$\underset{\mid P C T)}{O P 2}$} & \\
\hline $\begin{array}{l}1.0 \\
2.0 \\
4.0 \\
8.0 \\
12.0 \\
16.0\end{array}$ & $\begin{array}{l}1730 . \\
1749 . \\
1776 . \\
1803 . \\
1806 . \\
1804 .\end{array}$ & $\begin{array}{r}.5 \\
0.0 \\
.1 \\
.3 \\
.4\end{array}$ & & $\begin{array}{l}12.8 \\
12.8 \\
12.9 \\
18.4 \\
28.2 \\
34.1\end{array}$ & & $\begin{array}{c}0 \\
0 \\
0 \\
18 \\
33 \\
31\end{array}$ & : & \multicolumn{2}{|c|}{$\begin{array}{l}3.230 \\
3.230 \\
3.150 \\
2.000 \\
2.000 \\
1.800\end{array}$} & \\
\hline $\begin{array}{l}\text { DI STANCE } \\
\text { (I NCHESI) }\end{array}$ & $\begin{array}{l}\text { TEMPER A TURE } \\
\text { (OEG F) }\end{array}$ & \multicolumn{4}{|c|}{$\begin{array}{c}\text { CONVERSION } \\
\text { EFFICIENCY } \\
\text { IBY ASH TRACER) } \\
\text { (PCTI }\end{array}$} & \multicolumn{3}{|c|}{$\begin{array}{l}\text { PARTICLE } \\
\text { IFREE-FALL) } \\
\text { VELOCITY } \\
\text { (CM. IS }\end{array}$} & & \\
\hline $\begin{array}{l}1.0 \\
2.0 \\
4.0 \\
6.0 \\
12.0 \\
16.0\end{array}$ & $\begin{array}{l}1738 . \\
1749 . \\
1776 . \\
1803 . \\
1806 . \\
1804 .\end{array}$ & $\begin{array}{l}.052 \\
.103 \\
.205 \\
.406 \\
.607 \\
.808\end{array}$ & & $\begin{array}{r}6.8 \\
6.3 \\
7.2 \\
39.2 \\
61.4 \\
73.6\end{array}$ & & & $\begin{array}{l}3.4 \\
3.4 \\
3.4 \\
3.4 \\
3.4 \\
3.4\end{array}$ & & & \\
\hline $\begin{array}{l}\text { DI STANCE } \\
\text { I INCHESI }\end{array}$ & $\begin{array}{l}\text { TE MPERATURE } \\
\text { (DEG F) }\end{array}$ & 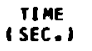 & & $\begin{array}{l}K \\
* G M_{*} / C M\end{array}$ & $\begin{array}{l}\text { KOIFF } \\
\text { N2. SEC }\end{array}$ & f.ATR & {$\left[\begin{array}{rl}k S \\
H_{0} * 1\end{array}\right.$} & & & 18 \\
\hline $\begin{array}{l}1.0 \\
2.0 \\
4.0 \\
0.0 \\
12.0 \\
16.0\end{array}$ & $\begin{array}{l}1738 . \\
1749 . \\
1716 . \\
1803 . \\
1806 . \\
1804 .\end{array}$ & $\begin{array}{l}.052 \\
.103 \\
.205 \\
.406 \\
.807 \\
.808\end{array}$ & & $\begin{array}{l}03534 \\
01629 \\
00971 \\
03691 \\
05717 \\
06279\end{array}$ & $\begin{array}{l}.2041 \\
.2048 \\
.2067 \\
.2086 \\
.2088 \\
.2087\end{array}$ & $\begin{array}{l}13 \\
87 \\
74 \\
61 \\
85 \\
71\end{array}$ & $\begin{array}{l}.04 \\
.01 \\
.02 \\
.04 \\
.07 \\
.08\end{array}$ & $\begin{array}{l}273 \\
770 \\
019 \\
484 \\
911 \\
981\end{array}$ & & $\begin{array}{l}173 \\
000 \\
047 \\
177 \\
274 \\
301\end{array}$ \\
\hline
\end{tabular}

\begin{tabular}{|c|c|c|c|c|c|c|c|c|}
\hline \multirow{2}{*}{$\begin{array}{c}\text { DISTAYCE } \\
\text { (INCHES) } \\
1.0 \\
2.0 \\
4.0 \\
8.0 \\
12.0 \\
16.0\end{array}$} & \multirow{2}{*}{$\begin{array}{l}\text { TE MPERA TURE } \\
\text { IDEG FI } \\
2990 . \\
2027 . \\
2076 . \\
2160^{\circ} \\
2206 . \\
2225 .\end{array}$} & $\begin{array}{l}\text { MOISTURE } \\
\text { IN CHAR } \\
\text { (PCI) }\end{array}$ & \multicolumn{2}{|c|}{$\begin{array}{l}\text { ASH IN } \\
\text { CHAR } \\
\text { (PCT) }\end{array}$} & $\begin{array}{l}\text { MOX } \\
\text { (PPH) }\end{array}$ & $\stackrel{02}{(P C T)}$ & $\begin{array}{l}\mathrm{CO} 2 \\
\text { (PCT) }\end{array}$ & \multirow{2}{*}{$\begin{array}{l}\text { CO } \\
\text { (PPH) } \\
540 . \\
580 . \\
640 . \\
300 . \\
180 . \\
160 .\end{array}$} \\
\hline & & $\begin{array}{l}0.0 \\
.3 \\
0.0 \\
0.0 \\
0.0 \\
.9\end{array}$ & \multicolumn{2}{|c|}{$\begin{array}{l}13.2 \\
13.5 \\
17.9 \\
24.5 \\
35.9 \\
41.0\end{array}$} & $\begin{array}{l}3 . \\
62 . \\
39 . \\
47: \\
50 .\end{array}$ & $\begin{array}{l}2.750 \\
2.700 \\
2.450 \\
2.100 \\
1.600 \\
1.400\end{array}$ & $\begin{array}{r}.540 \\
.540 \\
.960 \\
1.330 \\
1.610 \\
2.110\end{array}$ & \\
\hline $\begin{array}{l}\text { DISTAVCE } \\
\text { IINCHESSI }\end{array}$ & $\begin{array}{l}\text { TEMPER ATUPE } \\
\text { TOEG FI }\end{array}$ & \multicolumn{3}{|c|}{$\begin{array}{l}\text { CONGERSION } \\
\text { EFFICIENCY } \\
\text { BY ASH TRACEA) } \\
\text { (PCT) }\end{array}$} & \multicolumn{3}{|c|}{$\begin{array}{l}\text { PAR TICLE } \\
\text { (FREE-FALLI GAS } \\
\text { VELOCIIY VELOLITY } \\
\text { ICH./SEC.) }\end{array}$} & \multirow{2}{*}{$\begin{array}{l}\text { RE YMOLDS } \\
\text { NUMER } \\
151 . \\
150 . \\
149 . \\
147 . \\
145 . \\
145 .\end{array}$} \\
\hline $\begin{array}{r}1.0 \\
2.0 \\
6.0 \\
12.0 \\
12.0 \\
16.0\end{array}$ & $\begin{array}{l}1998 . \\
2021: \\
2076 . \\
2169 . \\
2206 . \\
2225 .\end{array}$ & $\begin{array}{l}.047 \\
.093 \\
.104 \\
.361 \\
.334 \\
.706\end{array}$ & \multicolumn{2}{|l|}{$\begin{array}{r}6.2 \\
1.9 \\
34.6 \\
56.0 \\
74.5 \\
79.9\end{array}$} & \multicolumn{2}{|c|}{$\begin{array}{l}3.29 \\
3.27 \\
3.24 \\
3.19 \\
3.16 \\
3.15\end{array}$} & $\begin{array}{l}31.12 \\
31.72 \\
52.14 \\
54.27 \\
33.46 \\
55.05\end{array}$ & \\
\hline $\begin{array}{l}\text { UlSIAYCE } \\
\text { IINCNESI }\end{array}$ & $\begin{array}{l}\text { It mPEKAIISKE } \\
\text { POIG \&I }\end{array}$ & $\begin{array}{l}\operatorname{lima} \\
\text { I sec. }\end{array}$ & \multicolumn{4}{|c|}{ 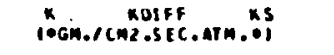 } & $x / X D I F F$ & \\
\hline $\begin{array}{l}1.0 \\
2: 0 \\
6.0 \\
1: 0 \\
10.0 \\
10.0\end{array}$ & $\begin{array}{l}1040 . \\
2021: \\
2370 . \\
2169 . \\
2209 . \\
2263 .\end{array}$ & $\begin{array}{l}.047 \\
.093 \\
.106 \\
.361 \\
.536 \\
.106\end{array}$ & $\begin{array}{l}.04155 \\
.03130 \\
.07662 \\
.030067 \\
.109225 \\
.10696\end{array}$ & $\begin{array}{l}.22196 \\
.22392 \\
.22722 \\
.23214 \\
.23593 \\
.23719\end{array}$ & & & $\begin{array}{l}.197 \\
.130 \\
.320 \\
.347 \\
.463 \\
.451\end{array}$ & \\
\hline
\end{tabular}

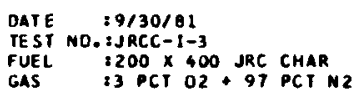

FUEL FEED RATE (GM/MIN) =
GAS FEED RATE (L/4IN) $=009$

EXCESS 02

- 200.69 
JROP TUBE FUKNACE SYSTEM OAIA REDUCTION PROGRAK

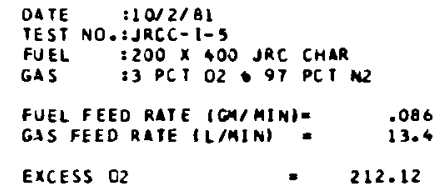


DROP TUBE FURNACE SYSTEM OATA REDUCTIOCM PROGRAY

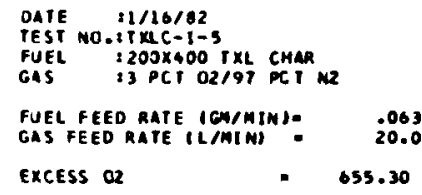


URUP IUEE FUHNACE SYSTEM DATA REOUCTION PROGREY
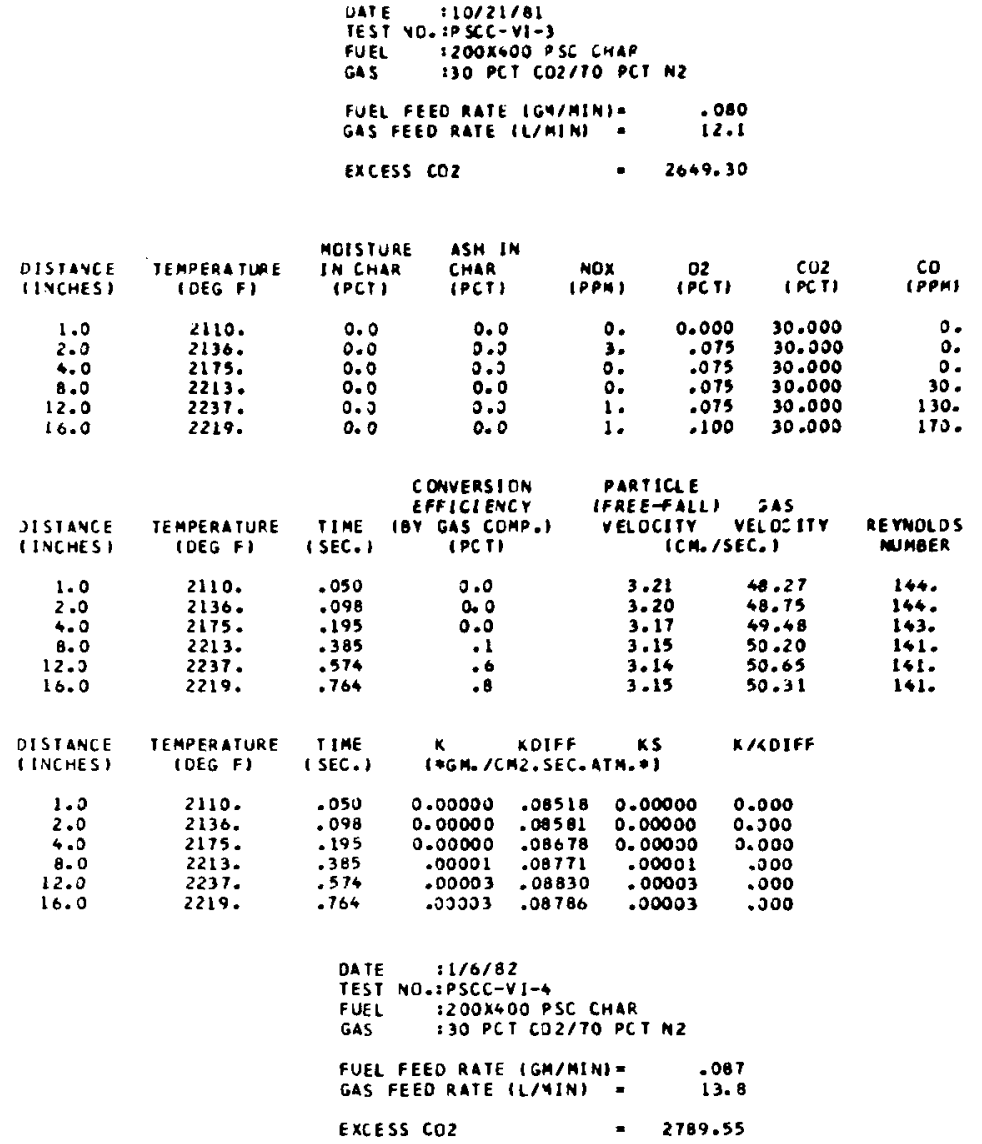

\begin{tabular}{|c|c|c|c|c|c|c|c|c|}
\hline $\begin{array}{l}\text { IISTANCE } \\
\text { IINCHESI }\end{array}$ & $\begin{array}{l}\text { TEMPERATURE } \\
\text { IOEG FI }\end{array}$ & $\begin{array}{l}\text { MOISTURE } \\
\text { IN CHAR } \\
\text { (PCT) }\end{array}$ & $\begin{array}{l}\text { ASH II } \\
\text { CHAR } \\
\text { (PCT) }\end{array}$ & & $\begin{array}{l}\text { OXX } \\
P M I\end{array}$ & $\underset{\text { (PCT) }}{02}$ & $\underset{\text { COST }}{\operatorname{COT}}$ & $\operatorname{CO}_{(P D M)}$ \\
\hline $\begin{array}{r}1.0 \\
2.0 \\
4.0 \\
1.0 \\
12.0 \\
10.0\end{array}$ & $\begin{array}{l}2322 . \\
23730 \\
24250 \\
2646 . \\
2650 . \\
2451 .\end{array}$ & $\begin{array}{l}0.0 \\
0.0 \\
0.0 \\
0.0 \\
0.0 \\
0.0\end{array}$ & $\begin{array}{l}0.0 \\
0.0 \\
0.0 \\
0.0 \\
0.0 \\
0.0\end{array}$ & & $\begin{array}{l}0 . \\
0 . \\
0 . \\
0 . \\
0 . \\
0 .\end{array}$ & $\begin{array}{l}0.000 \\
.100 \\
.100 \\
.070 \\
.070 \\
.050\end{array}$ & $\begin{array}{l}30.000 \\
30.000 \\
30.000 \\
30.000 \\
30.000 \\
30.000\end{array}$ & $\begin{array}{l}0 . \\
20 . \\
50 . \\
160 . \\
240 . \\
400 .\end{array}$ \\
\hline $\begin{array}{l}\text { DISTANCE } \\
\text { (IVCHESI }\end{array}$ & $\begin{array}{l}\text { TEMPERATURE } \\
\text { (UEG F) }\end{array}$ & $\underset{\text { ISIME }}{\text { ISEC. }}$ & $\begin{array}{l}\text { CONWERS ID } \\
\text { EFF ICIEN } \\
\text { (BY GAS CO } \\
\text { (PCI) }\end{array}$ & $\begin{array}{l}\text { ON } \\
\text { IS } \\
\text { MP . I }\end{array}$ & $\begin{array}{l}\text { PAAT } \\
\text { IFREE } \\
\text { VELO }\end{array}$ & $\begin{array}{l}\text { CLE } \\
\text { FALL) } \\
\text { i IY } \\
\text { ICM./SE }\end{array}$ & $\begin{array}{l}\text { GAS } \\
\text { VELOC ITY } \\
\text { EC.1 }\end{array}$ & $\begin{array}{l}\text { RE YNOLOS } \\
\text { NUMBER }\end{array}$ \\
\hline $\begin{array}{r}1.0 \\
2.0 \\
3.0 \\
8.0 \\
12.0 \\
10.0\end{array}$ & $\begin{array}{l}2322 . \\
2373 . \\
2425 . \\
26640 \\
2450 . \\
2451 .\end{array}$ & $\begin{array}{l}.041 \\
.080 \\
.159 \\
.314 \\
.464 \\
.624\end{array}$ & $\begin{array}{r}0.0 \\
.1 \\
.2 \\
.8 \\
1.2 \\
1.9\end{array}$ & & $\begin{array}{l}3 . \\
3 . \\
3 . \\
3 . \\
3 . \\
3 .\end{array}$ & & $\begin{array}{l}59.71 \\
60.81 \\
61.94 \\
62.34 \\
62.47 \\
62.46\end{array}$ & $\begin{array}{l}159 . \\
151 . \\
150 . \\
155 . \\
155 . \\
155 .\end{array}$ \\
\hline $\begin{array}{l}\text { JISIANCE } \\
\text { IIYCAESSI }\end{array}$ & $\begin{array}{l}\text { TIMPERA TURE } \\
\text { IOEG FI }\end{array}$ & $\begin{array}{l}\operatorname{lime}_{\text {ISEC.) }} \\
\text { ISEC }\end{array}$ & $\mathbb{R}_{1 \in \Delta M . / C}$ & $\begin{array}{l}\text { KOIFF } \\
\qquad 2.5 E C . A\end{array}$ & AIN.. & & K/KDIff & \\
\hline $\begin{array}{l}1.0 \\
2.0 \\
6.0 \\
3.0 \\
1 \% .0 \\
16.0\end{array}$ & $\begin{array}{l}2322 . \\
2373 . \\
2625 . \\
2664 . \\
2650 . \\
2451 .\end{array}$ & $\begin{array}{l}.041 \\
.080 \\
.154 \\
.316 \\
.064 \\
.024\end{array}$ & $\begin{array}{r}0.00000 \\
.00004 \\
.00004 \\
.00001 \\
.03001 \\
.00009\end{array}$ & $\begin{array}{l}.09034 \\
.09162 \\
.09289 \\
.09335 \\
.09390 \\
.09351\end{array}$ & $\begin{array}{l}0.0 \\
.0 \\
.0 \\
.0 \\
.0 \\
.0\end{array}$ & $\begin{array}{l}1000 \\
0004 \\
0004 \\
0007 \\
0007 \\
0009\end{array}$ & $\begin{array}{r}0.000 \\
.000 \\
.000 \\
.001 \\
.001 \\
.001\end{array}$ & \\
\hline
\end{tabular}


DROP TUBE FURMACE SYSTEM DATA RE OUCTION PROGAAN

$$
\begin{aligned}
& \text { DATE NI/19/82 } \\
& \text { FUEL } \$ 200 \times 400 \text { PSC CHAR } \\
& \text { GAS IIS PCT CO2/OS PCT N2 } \\
& \begin{array}{l}
\text { FUEL FEEO RATE (GY/MIN): } \\
\text { GAS FEEO RATE (L/YIN) }
\end{array} \\
& \text { EXCESS } \mathrm{CO} 2=1915.75
\end{aligned}
$$

\begin{tabular}{|c|c|c|c|c|c|c|c|}
\hline $\begin{array}{l}\text { DISTANCE } \\
\text { IINCHESI }\end{array}$ & $\begin{array}{l}\text { TE MPERA TURE } \\
\text { IDEG FI }\end{array}$ & $\begin{array}{l}\text { MDISTURE } \\
\text { IN CHAR } \\
\text { IPCTI }\end{array}$ & $\begin{array}{l}\text { ASH IN } \\
\text { CHAR } \\
\text { IPCTI }\end{array}$ & $\begin{array}{l}\operatorname{Max} \\
\text { (PPM) }\end{array}$ & $\operatorname{lPC}_{(P C)}^{02}$ & $\cos _{(P C)}^{\cos }$ & $\underset{\text { (PPM) }}{\text { CO }}$ \\
\hline $\begin{array}{r}1.0 \\
2.0 \\
4.0 \\
B .0 \\
12.0 \\
16.0\end{array}$ & $\begin{array}{l}24677^{\circ} \\
2520^{\circ} \\
25960^{\circ} \\
26380^{\circ} \\
26430^{\circ}\end{array}$ & $\begin{array}{l}0.0 \\
0.0 \\
0.0 \\
0.0 \\
0.0 \\
0.0\end{array}$ & $\begin{array}{l}0.0 \\
0.00 \\
0.0 \\
0.0 \\
0.0 \\
0.0\end{array}$ & $\begin{array}{l}0 . \\
0 . \\
0: \\
1: \\
1 . \\
2 .\end{array}$ & $\begin{array}{r}0.000 \\
.075 \\
0.000 \\
0.000 \\
.050 \\
.063\end{array}$ & $\begin{array}{l}14.500 \\
14.500 \\
14.500 \\
14.500 \\
14.500 \\
14.500\end{array}$ & $\begin{array}{r}0 . \\
10 . \\
50 . \\
80 . \\
280 . \\
480 .\end{array}$ \\
\hline
\end{tabular}

\begin{tabular}{|c|c|c|c|c|c|c|}
\hline \multirow{2}{*}{$\begin{array}{c}\text { DI SIANCE } \\
\text { (INCHES ) } \\
1.0 \\
2.0 \\
0.0 \\
0.0 \\
12.0 \\
16.0\end{array}$} & \multirow{2}{*}{$\begin{array}{l}\text { TE MPERA IURE } \\
\text { IDEG FI } \\
2467 . \\
2528 . \\
2596 . \\
2638 . \\
2643 \\
2637\end{array}$} & \multirow{2}{*}{$\begin{array}{l}\text { TI IAE } \\
\text { I SEC. I } \\
.037 \\
.074 \\
.145 \\
.285 \\
.426 \\
.566\end{array}$} & \multicolumn{2}{|c|}{$\begin{array}{l}\text { CONYEASION } \\
\text { EFFICIENCY } \\
\text { (OY GAS COMP.I } \\
\text { (PCT) }\end{array}$} & $\begin{array}{l}\text { PART ICLE } \\
\text { IFREE FALL) } \\
\text { VEOCITY } \\
\text { (CM.) }\end{array}$ & $\begin{array}{l}\text { GAS } \\
\text { VELOC IT } \\
\text { SEC. }\end{array}$ \\
\hline & & & $\begin{array}{r}0.0 \\
.1 \\
.3 \\
.4 \\
1.5 \\
2.6\end{array}$ & & $\begin{array}{l}3.13 \\
3.10 \\
3.06 \\
3.04 \\
3.04 \\
3.04\end{array}$ & $\begin{array}{l}65.43 \\
66.79 \\
68.30 \\
69.25 \\
69.36 \\
69.22\end{array}$ \\
\hline $\begin{array}{l}\text { ( STAYCE } \\
\text { ( NCHES) }\end{array}$ & $\begin{array}{l}\text { TEMPERATURE } \\
\text { (DEG FI }\end{array}$ & $\begin{array}{c}\text { TIME } \\
\text { I SEC. }\end{array}$ & $\underset{i * G N_{0} / C}{K}$ & $\begin{array}{l}\text { KDIFF } \\
\text { M2.SEC. }\end{array}$ & at m.*s & K/XDIFF \\
\hline $\begin{aligned} 1.0 \\
2.0 \\
4.0 \\
8.0 \\
12.0 \\
16.0\end{aligned}$ & $\begin{array}{l}2467 . \\
2528 . \\
2596 . \\
2638 . \\
2643 . \\
2637 .\end{array}$ & $\begin{array}{l}.037 \\
.074 \\
.145 \\
.265 \\
.426 \\
.566\end{array}$ & $\begin{array}{l}0.00000 \\
.00004 \\
.00011 \\
.00009 \\
.00022 \\
.00028\end{array}$ & $\begin{array}{l}.09391 \\
.09537 \\
.09698 \\
.09799 \\
.09811 \\
.09796\end{array}$ & $\begin{array}{l}0.00000 \\
.00004 \\
.00011 \\
.00009 \\
.00022 \\
.00020\end{array}$ & $\begin{array}{l}0.000 \\
.000 \\
.001 \\
.001 \\
.002 \\
.003\end{array}$ \\
\hline
\end{tabular}

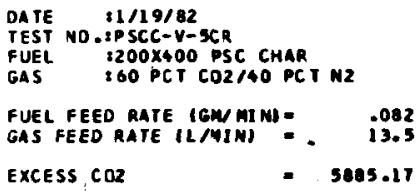


DROP TUBE FURAGE SYSTEM DATA REDUCTICN PROGPAM

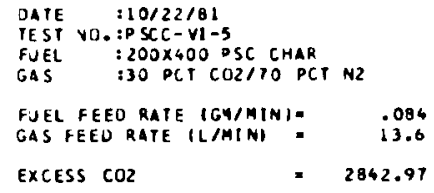

\begin{tabular}{|c|c|c|c|c|c|c|c|}
\hline $\begin{array}{l}\text { DISIANCE } \\
\text { (INCHES I }\end{array}$ & $\begin{array}{l}\text { TE MP ER A TURE } \\
\text { (OEG FI }\end{array}$ & $\begin{array}{l}\text { TIRE } \\
\text { I SEC. }\end{array}$ & $\begin{array}{r}\text { CONVERSI } \\
\text { EFFICIEN } \\
\text { AOY GAS CO } \\
\text { IPCTI }\end{array}$ & & $\begin{array}{l}\text { PARTICLE } \\
\text { IFREE-FALL) } \\
\text { VELOCITY } \\
\text { ICM. }\end{array}$ & $\begin{array}{l}\text { SAS } \\
\text { YEL DCITY } \\
\text { SEC. I }\end{array}$ & $\begin{array}{l}\text { REYMOL DS } \\
\text { MUMBER }\end{array}$ \\
\hline $\begin{array}{r}1.0 \\
2.0 \\
4.0 \\
8.0 \\
12.0 \\
16.0\end{array}$ & $\begin{array}{l}2467 . \\
2528 . \\
2596 . \\
2638 . \\
2643 . \\
2637 .\end{array}$ & $\begin{array}{l}.039 \\
.078 \\
.153 \\
.302 \\
.450 \\
.599\end{array}$ & $\begin{array}{r}0.0 \\
.1 \\
1.4 \\
1.7 \\
3.7 \\
5.9\end{array}$ & & $\begin{array}{l}3.01 \\
2.98 \\
2.95 \\
2.93 \\
2.93 \\
2.93\end{array}$ & $\begin{array}{l}61.79 \\
63.08 \\
66.51 \\
65.60 \\
65.51 \\
65.37\end{array}$ & $\begin{array}{l}152 . \\
150, \\
149 . \\
148 . \\
148 . \\
148 .\end{array}$ \\
\hline $\begin{array}{l}\text { DI SIANCE } \\
\text { (INCHES) }\end{array}$ & $\begin{array}{l}\text { TE MPERA TURE } \\
\text { (DEG F) }\end{array}$ & TIME & $\log _{1 M_{-} / C}^{K}$ & $\begin{array}{l}\text { KOIFF } \\
\text { Q2.SEC. }\end{array}$ & Arm. $\begin{array}{r}K S \\
* 1\end{array}$ & $K /<$ OIfF & \\
\hline $\begin{array}{r}1.0 \\
2.0 \\
4.0 \\
9.0 \\
12.0 \\
16.0\end{array}$ & $\begin{array}{l}2667 . \\
2528 . \\
2596 . \\
2638 . \\
2643 . \\
2637 .\end{array}$ & $\begin{array}{l}.039 \\
.078 \\
.153 \\
.302 \\
.450 \\
.599\end{array}$ & $\begin{array}{r}0.00000 \\
.00004 \\
.00008 \\
.00016 \\
.00024 \\
.00030\end{array}$ & $\begin{array}{l}.09391 \\
.09537 \\
.09696 \\
.09799 \\
.09811 \\
.09796\end{array}$ & $\begin{array}{r}0.00000 \\
.00004 \\
.00008 \\
.00016 \\
.00024 \\
.00030\end{array}$ & $\begin{array}{l}0.000 \\
.000 \\
.001 \\
.002 \\
.002 \\
.003\end{array}$ & \\
\hline
\end{tabular}


OROP TUEE FURMACE SYSTEM DAIA REDUCIION PROGRAY

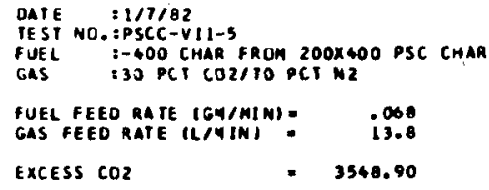

\begin{tabular}{|c|c|c|c|c|c|c|c|c|c|}
\hline $\begin{array}{l}\text { OI STANCE } \\
\text { II NCHESI }\end{array}$ & $\begin{array}{l}\text { TEMPERATURE } \\
\text { IDEG FI }\end{array}$ & \multicolumn{2}{|c|}{$\begin{array}{l}\text { MOI S TURE } \\
\text { IN CHAR } \\
\text { (PC TI }\end{array}$} & \multicolumn{2}{|c|}{$\begin{array}{l}\text { ASH IN } \\
\text { CHAR } \\
\text { (PCT) }\end{array}$} & $\begin{array}{l}\text { MOX } \\
\text { (PPMI) }\end{array}$ & $\begin{array}{l}02 \\
\text { (PCI) }\end{array}$ & $\begin{array}{l}\mathrm{CO} 2 \\
\text { (PCT) }\end{array}$ & \multirow{2}{*}{$\begin{array}{r}\text { CD } \\
\text { (PPH } \\
0 . \\
0 . \\
75 . \\
550 . \\
1000 \\
1000 .\end{array}$} \\
\hline $\begin{array}{r}1.0 \\
2.0 \\
4.0 \\
8.0 \\
12.0 \\
16.0\end{array}$ & $\begin{array}{l}2667 . \\
2528 . \\
2596 . \\
2638 . \\
2643 . \\
2637 .\end{array}$ & $\begin{array}{l}0.0 \\
0.0 \\
0.0 \\
0.0 \\
0.0 \\
0.0\end{array}$ & & $\begin{array}{l}0.0 \\
0.0 \\
0.0 \\
0.0 \\
0.0 \\
0.0\end{array}$ & & $\begin{array}{l}0: \\
0: \\
0: \\
5: \\
25:\end{array}$ & $\begin{array}{l}0.000 \\
0.000 \\
0.000 \\
0.000 \\
0.000 \\
0.000\end{array}$ & $\begin{array}{l}30.000 \\
30.000 \\
30.000 \\
30.000 \\
30.000 \\
30.000\end{array}$ & \\
\hline $\begin{array}{l}\text { OISIANCE } \\
\text { IINCHESI }\end{array}$ & $\begin{array}{l}\text { TEMPERA IURE } \\
\text { (DEG FI }\end{array}$ & \multicolumn{4}{|c|}{$\begin{array}{l}\text { CONYERSIJN } \\
\text { EFFICIENCY } \\
\text { E IBY GAS CUMP.I } \\
\text {-) } \\
\text { IPCI) }\end{array}$} & \multicolumn{2}{|c|}{$\begin{array}{l}\text { PARTICLE } \\
\text { IFAEE-FALLI } \\
\text { VELOCI IY } \\
\text { ICH.I }\end{array}$} & $\begin{array}{l}\text { GAS } \\
\text { VELOCITY } \\
\text { SEC.I }\end{array}$ & $\begin{array}{l}\text { REYMOLDS } \\
\text { NUMAER }\end{array}$ \\
\hline $\begin{array}{r}1.0 \\
2.0 \\
4.0 \\
1.0 \\
12.5 \\
16.0\end{array}$ & $\begin{array}{l}2467 . \\
2528: \\
2596 . \\
2638 . \\
2643 . \\
2037 .\end{array}$ & $\begin{array}{l}.041 \\
.099 \\
.151 \\
.309 \\
.661 \\
.614\end{array}$ & \multicolumn{3}{|c|}{$\begin{array}{l}0.0 \\
0.0 \\
.5 \\
3.3 \\
4.8 \\
0.1\end{array}$} & \multicolumn{2}{|c|}{$\begin{array}{l}.39 \\
.30 \\
.30 \\
.30 \\
.38 \\
.38\end{array}$} & $\begin{array}{l}62.70 \\
64.01 \\
65.45 \\
66.36 \\
66.47 \\
08.33\end{array}$ & $\begin{array}{l}\text { 154. } \\
\text { 153: } \\
151 . \\
150 . \\
150 . \\
150 .\end{array}$ \\
\hline $\begin{array}{l}\text { DISTANCE } \\
\text { IINCHES I }\end{array}$ & $\begin{array}{l}\text { TE MPERATUKE } \\
\text { IDEC FI }\end{array}$ & $\begin{array}{l}\text { YIME } \\
\text { ISEC.) }\end{array}$ & & \multicolumn{2}{|c|}{$\begin{array}{c}K \\
\text { KOIFF } \\
\text { KGM.ICYZ.SEC.A }\end{array}$} & ATM." & & K/KOIFF & \\
\hline $\begin{array}{l}1.0 \\
2.0 \\
4.0 \\
0.0 \\
12.0 \\
10.0\end{array}$ & $\begin{array}{l}2407 . \\
2528 . \\
2596 . \\
2638 . \\
2643 . \\
2637 .\end{array}$ & $\begin{array}{l}.041 \\
.080 \\
.08151 \\
.309 \\
.461 \\
.014\end{array}$ & & $\begin{array}{l}.00000 \\
.03000 \\
.00003 \\
.00011 \\
.00011 \\
.00011\end{array}$ & $\begin{array}{l}.26195 \\
.26603 \\
.27053 \\
.27335 \\
.27368 \\
.27325\end{array}$ & $\begin{array}{l}0.0 \\
0.8 \\
: 0 \\
.0\end{array}$ & $\begin{array}{l}000 \\
1000 \\
0013 \\
011 \\
011 \\
011\end{array}$ & $\begin{array}{l}0.000 \\
0.000 \\
.000 \\
.000 \\
.000 \\
.000\end{array}$ & \\
\hline
\end{tabular}


DROP IUAE FLRNACE SYSTEM DATA REDCTICM PROGRAM

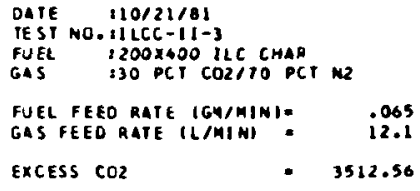


DROP TUDE FURMACE SYSTEM DATA REDUCTICM PROGRAM

$$
\begin{aligned}
& \text { OATE PIOSI YO.BILCC-11-s }
\end{aligned}
$$

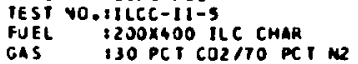

$$
\begin{aligned}
& \begin{array}{l}
\text { FUEL FEEO RAIE (GN/MIN): } \\
\text { GAS FEED RAIE ILMINI) : } \\
\text { i4.7 }
\end{array} \\
& \text { ExCESS CO2 }
\end{aligned}
$$

\begin{tabular}{|c|c|c|c|c|c|c|c|c|c|}
\hline $\begin{array}{l}\text { DISTANCE } \\
\text { IINCHESI }\end{array}$ & $\begin{array}{l}\text { TEMPERATURE } \\
\text { TDEG FI }\end{array}$ & \multicolumn{2}{|c|}{$\begin{array}{l}\text { MDI S T URE } \\
\text { IM CMAR } \\
\text { (PCT) }\end{array}$} & \multicolumn{2}{|c|}{$\begin{array}{l}\text { ASH IN } \\
\text { CMAR } \\
(P C T)\end{array}$} & $\begin{array}{l}0 x \\
\text { PMI }\end{array}$ & (P2) & $\begin{array}{l}\text { CO2 } \\
\text { (PCT) }\end{array}$ & $\cos _{(\operatorname{pon})}$ \\
\hline $\begin{array}{r}1.0 \\
2.0 \\
4.0 \\
8.0 \\
12.0 \\
16.0\end{array}$ & $\begin{array}{l}2467 . \\
2528 . \\
2590^{\circ} \\
2638 . \\
2643 . \\
2637 .\end{array}$ & $\begin{array}{l}0.0 \\
0.0 \\
0.0 \\
0.0 \\
0.0 \\
0.0\end{array}$ & & $\begin{array}{l}0.0 \\
0.0 \\
0.0 \\
0.0 \\
0.0 \\
0.0\end{array}$ & & $\begin{array}{l}0 . \\
0: \\
0 . \\
3 . \\
3 . \\
9 .\end{array}$ & $\begin{array}{r}0.000 \\
.100 \\
.100 \\
.100 \\
.100 \\
.100\end{array}$ & $\begin{array}{l}30.000 \\
30.000 \\
30.000 \\
30.000 \\
30.000 \\
30.000\end{array}$ & $\begin{array}{l}30 . \\
170 . \\
1000 . \\
1920 . \\
2340 .\end{array}$ \\
\hline $\begin{array}{l}\text { DISIANCE } \\
\text { IINCHESI }\end{array}$ & $\begin{array}{l}\text { TEMPERA TURE } \\
\text { IOEG FI }\end{array}$ & \multicolumn{4}{|c|}{$\begin{array}{c}\text { CONVERSION } \\
\text { EFF ICIENCY } \\
\text { IBY GAS COMP.) } \\
\text { (PCT) }\end{array}$} & \multicolumn{2}{|c|}{$\begin{array}{l}\text { PAR IICLE } \\
\text { (FREE-FALL) } \\
\text { VELOCI IY } \\
\text { (CH./SE }\end{array}$} & $\begin{array}{l}\text { GAS } \\
\text { veLOCITY } \\
\text { EC. }\end{array}$ & $\begin{array}{l}\text { REYMOL OS } \\
\text { MUMBER }\end{array}$ \\
\hline $\begin{array}{r}1.0 \\
2.0 \\
4.0 \\
8.0 \\
12.0 \\
16.0\end{array}$ & $\begin{array}{l}2467 . \\
2528 . \\
2596 . \\
2638 . \\
2643 . \\
2637 .\end{array}$ & $\begin{array}{l}.037 \\
.072 \\
.142 \\
.279 \\
.417 \\
.554\end{array}$ & \multicolumn{3}{|c|}{$\begin{array}{r}0.0 \\
1.2 \\
1.2 \\
7.2 \\
13.8 \\
16.9\end{array}$} & \multicolumn{2}{|c|}{$\begin{array}{l}3.24 \\
3.21 \\
3.18 \\
3.15 \\
3.15 \\
3.15\end{array}$} & $\begin{array}{l}66.79 \\
68.18 \\
69.12 \\
10.69 \\
10.81 \\
70.66\end{array}$ & $\begin{array}{l}164 . \\
163 . \\
161 . \\
160 . \\
160 . \\
160 .\end{array}$ \\
\hline $\begin{array}{l}\text { DISTANCE } \\
\text { (INCHES) }\end{array}$ & $\begin{array}{l}\text { TEMPER A IURE } \\
\text { (DEG F) }\end{array}$ & $\begin{array}{l}\operatorname{IIME}_{\text {ISEC.) }} \\
\text { (SEC }\end{array}$ & \multicolumn{5}{|c|}{$\begin{array}{l}K \\
\text { I*GM./CM KOIFF }\end{array}$} & K/KOIFF & \\
\hline $\begin{array}{r}1.0 \\
2.0 \\
4.0 \\
8.0 \\
12.0 \\
16.0\end{array}$ & $\begin{array}{l}2467 . \\
2528 . \\
2596 . \\
2638 . \\
2643 . \\
2637 .\end{array}$ & $\begin{array}{l}.037 \\
.072 \\
.142 \\
.279 \\
.617 \\
.554\end{array}$ & & $\begin{array}{l}.00000 \\
.00009 \\
.00026 \\
.00081 \\
.00106 \\
.00099\end{array}$ & $\begin{array}{l}.09049 \\
.09190 \\
.09346 \\
.09443 \\
.09454 \\
.09439\end{array}$ & $\begin{array}{l}0.0 \\
.0 \\
.0 \\
.0 \\
.0\end{array}$ & $\begin{array}{l}000 \\
009 \\
027 \\
1081 \\
108 \\
100\end{array}$ & $\begin{array}{l}0.000 \\
.001 \\
.003 \\
.009 \\
.011 \\
.010\end{array}$ & \\
\hline
\end{tabular}

\begin{tabular}{|c|c|c|c|c|c|c|c|}
\hline $\begin{array}{l}\text { ISTANCE } \\
\text { INCHESS }\end{array}$ & $\begin{array}{l}\text { TEMPERA TURE } \\
\text { (DEG FI) }\end{array}$ & $\begin{array}{l}\text { MOISTURE } \\
\text { IN CHAR } \\
\text { IPCT) }\end{array}$ & $\begin{array}{l}\text { ASH IN } \\
\text { CHAR } \\
\text { (PCT) }\end{array}$ & $\underset{\text { (PPM) }}{\text { MOX }}$ & $\underset{1 P C N 1)}{102}$ & $\begin{array}{l}\operatorname{COO} \\
(\operatorname{PC} T)\end{array}$ & (PPA) \\
\hline $\begin{array}{l}1.0 \\
2.0 \\
4: 0 \\
12.0 \\
12.0 \\
16.0\end{array}$ & $\begin{array}{l}2467 . \\
2528 . \\
2596 . \\
2638 . \\
2643 . \\
2637 .\end{array}$ & $\begin{array}{l}0.0 \\
0.0 \\
0.0 \\
0.0 \\
0.0 \\
0.0\end{array}$ & $\begin{array}{l}0.0 \\
0.0 \\
0.0 \\
0.0 \\
0.0 \\
0.0\end{array}$ & $\begin{array}{l}0 . \\
1 . \\
20 \\
11 . \\
14 .\end{array}$ & $\begin{array}{r}0.000 \\
.100 \\
.050 \\
.050 \\
.050 \\
0.000\end{array}$ & $\begin{array}{l}30.0005 \\
30.000 \\
30.000 \\
30.000 \\
30.000 \\
30.000\end{array}$ & $\begin{array}{l}0 . \\
360 . \\
700: \\
2600: \\
3000 . \\
3100 .\end{array}$ \\
\hline
\end{tabular}

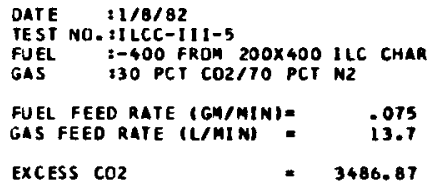

\begin{tabular}{|c|c|c|c|c|c|c|}
\hline $\begin{array}{l}\text { I SIANCE } \\
\text { UINCHESI }\end{array}$ & $\begin{array}{l}\text { TE MPERA TURE } \\
\text { DOEG FI }\end{array}$ & $\begin{array}{l}\operatorname{TIME}_{\text {I MEC. }} \\
\text { I SEC. }\end{array}$ & $\begin{array}{l}\text { CONYERSION } \\
\text { EFFICIENCY } \\
\text { IOY GAS CONP.) } \\
\text { IPC II }\end{array}$ & $\begin{array}{c}\text { PARTICLE } \\
\text { PFREE-FALLI) } \\
\text { VELOCIIY } \\
\text { ICM.Is }\end{array}$ & $\begin{array}{l}\text { SEAS } \\
\text { EEL OE ITr } \\
\text { EC.) }\end{array}$ & PE MOLO \\
\hline $\begin{array}{l}1.0 \\
2.00 \\
4.0 \\
6.0 \\
12.0 \\
16.0\end{array}$ & $\begin{array}{l}2467 . \\
2528: \\
2596: \\
2630: \\
2643: \\
2631:\end{array}$ & $\begin{array}{l}.041 \\
0.041 \\
.159 \\
0.313 \\
.467 \\
.6621\end{array}$ & $\begin{array}{r}0.0 \\
2.2 \\
4.2 \\
14.3 \\
17.9 \\
30.5\end{array}$ & $\begin{array}{l}.09 \\
.09 \\
.09 \\
.08 \\
.08 \\
.08\end{array}$ & $\begin{array}{l}62.25 \\
63.54 \\
64.98 \\
65.08 \\
65.99 \\
65.85\end{array}$ & $\begin{array}{l}1530 \\
132 . \\
1500 \\
1490 \\
149: \\
1490\end{array}$ \\
\hline
\end{tabular}

\begin{tabular}{|c|c|c|c|c|c|c|}
\hline $\begin{array}{l}\text { IISIAYLE } \\
\text { inchesi }\end{array}$ & $\begin{array}{l}\text { TEMPERA TURE } \\
\text { IOEG F) }\end{array}$ & $\begin{array}{l}\operatorname{lime} \\
1 \text { Sec. }\end{array}$ & $\underset{10 G N .1}{K}$ & $\begin{array}{l}\text { KDIFF } \\
12 . S E C \text {. }\end{array}$ & 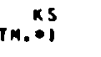 & DOIF \\
\hline $\begin{array}{r}1.0 \\
2.0 \\
6.3 \\
8.0 \\
12.0 \\
16.0\end{array}$ & $\begin{array}{l}2467 . \\
2528: \\
2596 . \\
2638: \\
26430 \\
2031:\end{array}$ & $\begin{array}{l}.041 \\
.081 \\
.159 \\
.313 \\
.467 \\
.621\end{array}$ & $\begin{array}{r}0.00000 \\
.00013 \\
.00013 \\
.00024 \\
.00020 \\
.00028\end{array}$ & $\begin{array}{r}.55301 \\
.551663 \\
.57112 \\
.57106 \\
.57770 \\
.57605\end{array}$ & $\begin{array}{r}0.00000 \\
000013 \\
0.00013 \\
000024 \\
0.00020 \\
.00028\end{array}$ & $\begin{array}{r}0.000 \\
.000 \\
.000 \\
.000 \\
.000 \\
.000\end{array}$ \\
\hline
\end{tabular}


DROP TUAE FURNACE SYSTEA DATA REOUCTION PROGAM
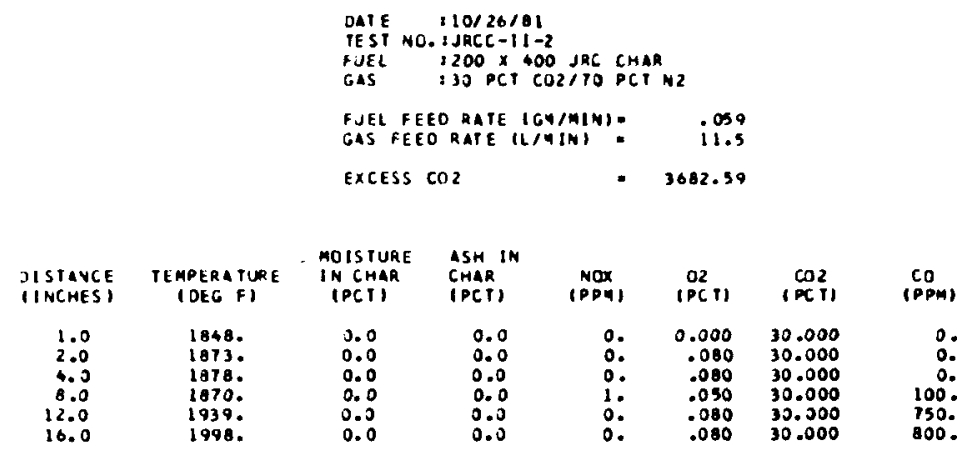

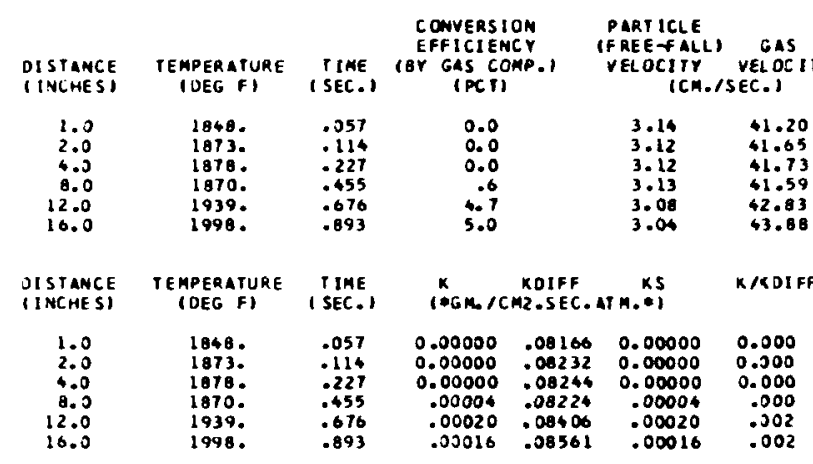

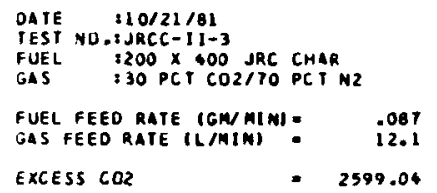

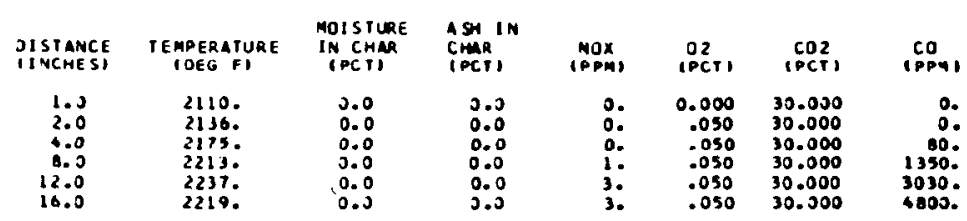

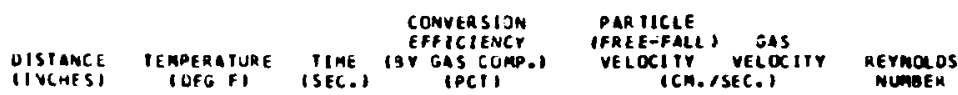

$\begin{array}{lllllll}1.3 & 2110 . & .050 & 0.0 & 2.90 & 43.27 & 144 . \\ 2.0 & 2136 . & .090 & 0.0 & 2.96 & 40.75 & 144 .\end{array}$

$\begin{array}{lllllll}2.3 & 2136 . & .099 & 0.0 & 2.96 & 40.75 & 144 . \\ 4.0 & 2175 . & .196 & .0 & 2.04 & 69.48 & 143 . \\ 1.1 & 2213 . & .397 & 0.1 & 2.92 & 50.20 & 141 .\end{array}$

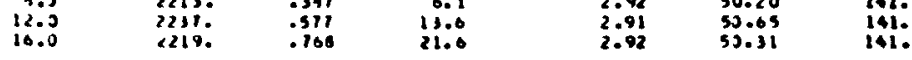

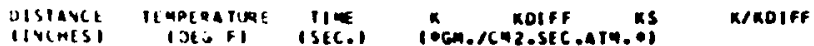

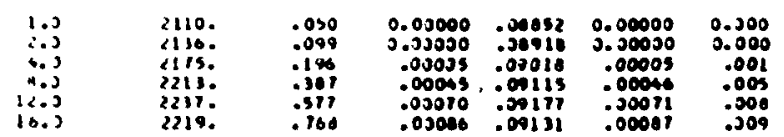


DROP TUBE FURNACE SYSTEM DATA REOUCTION PROGRAM

OATE $21 / 6 / 82$

IESI NC.: JACC - TI - G

GAS 130 PCT CO2110 PCT M2

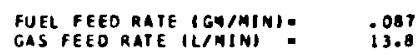

EXCESS CO2 $\quad 2979.25$

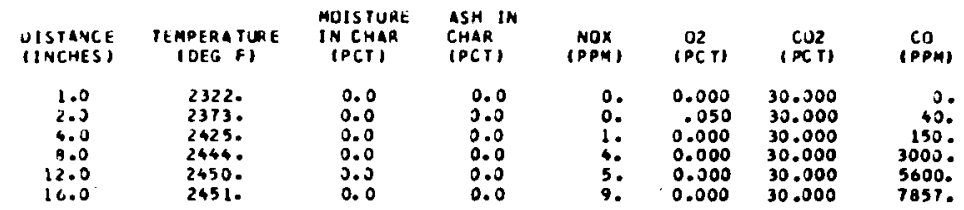

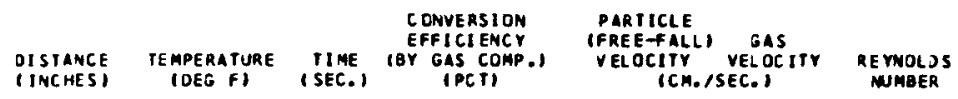

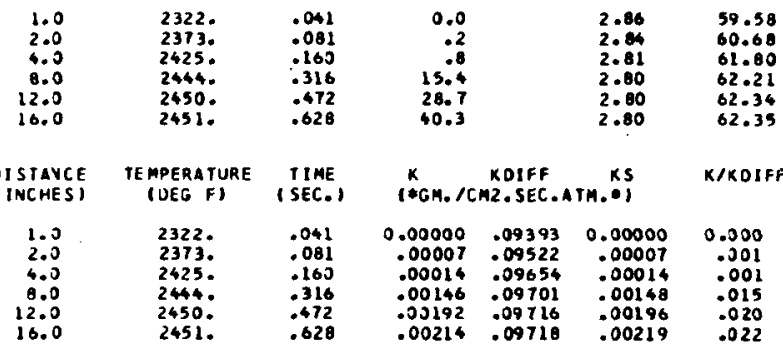

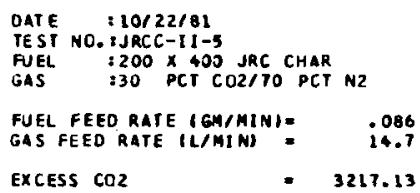

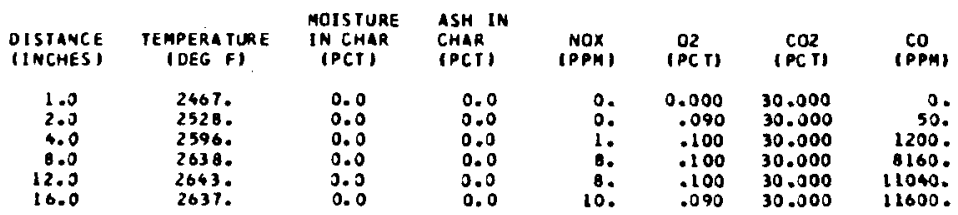

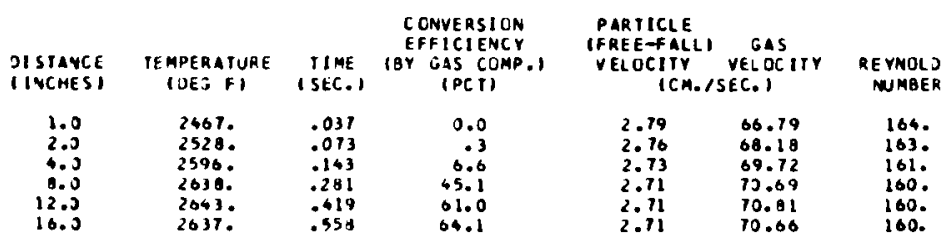

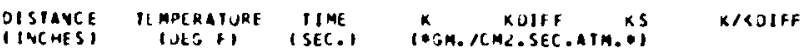

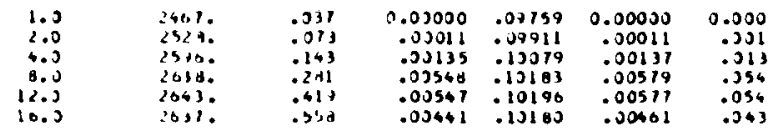


DHUP TUAE FURNALE SYSTEM OATA REDUCTION PROGKAM

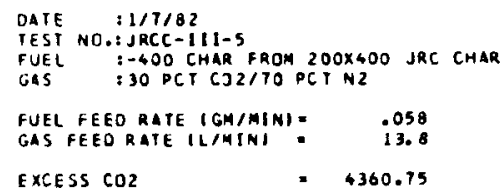

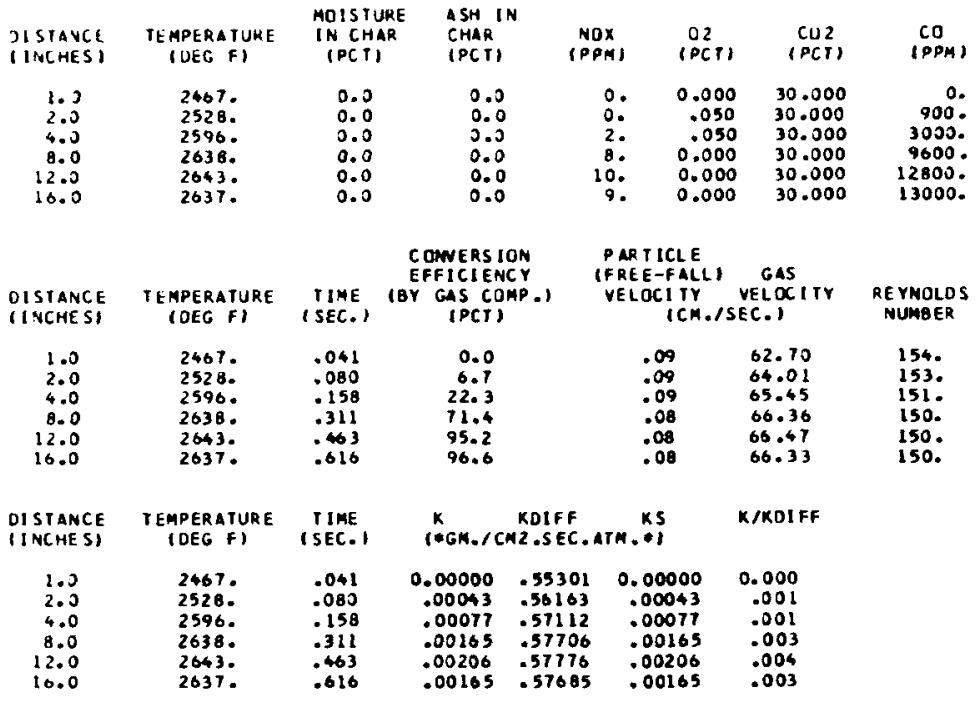


DROP TUBE FLRMACE SYSTEM DATA REOUCTION PROGRAM

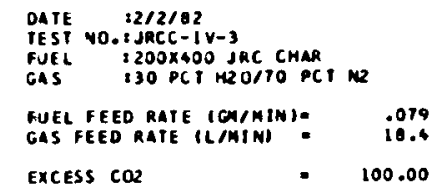

\begin{tabular}{|c|c|c|c|c|c|c|c|}
\hline $\begin{array}{l}\text { DISTANCE } \\
\text { (INCHESI) }\end{array}$ & $\begin{array}{c}\text { TEMPERATURE } \\
\text { IDEG FI }\end{array}$ & $\begin{array}{l}\text { MOIS T UAAE } \\
\text { IN CMAR } \\
\text { (PCT) }\end{array}$ & 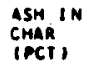 & 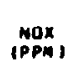 & $\begin{array}{l}02 \\
\text { (PCT) }\end{array}$ & $\begin{array}{c}\operatorname{CO2} \\
\text { (PC II) }\end{array}$ & $\underset{\text { (PPM) }}{\text { CO }}$ \\
\hline $\begin{array}{r}1.0 \\
2.0 \\
4.0 \\
8.0 \\
12.0 \\
16.0\end{array}$ & $\begin{array}{l}2110 . \\
2136 . \\
2275 . \\
2213 . \\
2231 . \\
2219 .\end{array}$ & $\begin{array}{l}0.0 \\
0.0 \\
0.0 \\
0.0 \\
0.0 \\
0.0\end{array}$ & $\begin{array}{l}0.0 \\
0.0 \\
0.0 \\
0.0 \\
0.0 \\
0.0\end{array}$ & $\begin{array}{l}0 . \\
0 . \\
0 . \\
20 \\
40\end{array}$ & $\begin{array}{r}0.000 \\
.050 \\
.050 \\
.010 \\
.010 \\
.100\end{array}$ & $\begin{array}{l}30.000 \\
30.000 \\
30.000 \\
30.000 \\
30.000 \\
30.000\end{array}$ & $\begin{array}{l}40 . \\
40 . \\
40 . \\
40 . \\
120 . \\
200 .\end{array}$ \\
\hline
\end{tabular}
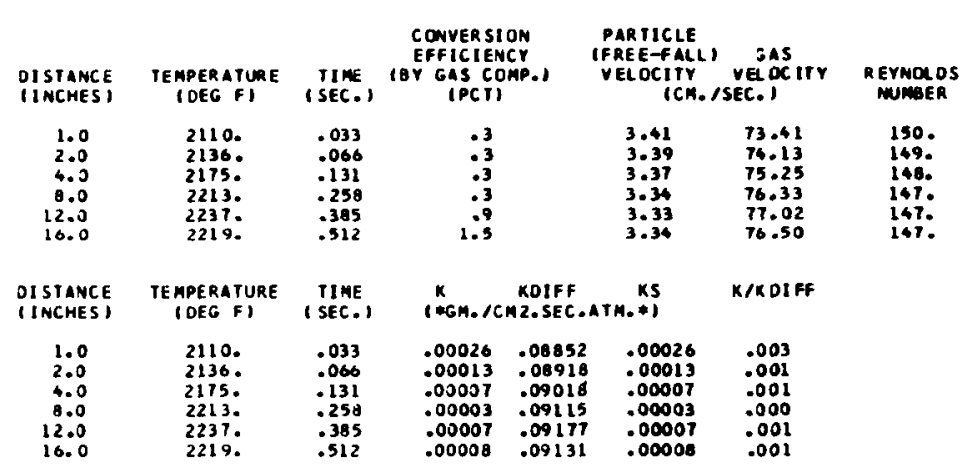

$$
\begin{aligned}
& \begin{array}{ll}
\text { OATE } & : 1 / 29 / 82 \\
\text { TESI NO. : } J R C C-I V-5 \\
\text { FUEL } & : 200 \times 400 \text { JRC CHAR } \\
\text { GAS } & : 30 \text { PCT H2O/10 PCI N2 }
\end{array} \\
& \begin{array}{l}
\text { FUEL FEED RATE (GM/MIN) } \\
\text { GAS FEED RATE (L/MIN) }
\end{array} \\
& \text { GAS FEEO RATE IL/MIN) = } 18.4
\end{aligned}
$$

\begin{tabular}{|c|c|c|c|c|c|c|c|}
\hline $\begin{array}{l}\text { DISTAYCE } \\
\text { lINCHESI }\end{array}$ & $\begin{array}{l}\text { JEMPERA TURE } \\
\text { IOEG FI }\end{array}$ & $\begin{array}{l}\text { MOIS TURE } \\
\text { IN CHAR } \\
\text { (PCT) }\end{array}$ & $\begin{array}{l}\text { ASH IN } \\
\text { CHAR } \\
\text { (PCI) }\end{array}$ & $\begin{array}{l}\text { NOX } \\
\text { (PPM) }\end{array}$ & $\underset{|P C T|}{O P 2}$ & $\mid \begin{array}{cc}\operatorname{Cos} 2 \\
|P C T|\end{array}$ & $\underset{\text { (PPM) }}{\text { CO }}$ \\
\hline $\begin{array}{r}1.0 \\
2.0 \\
4.0 \\
8.0 \\
12.0 \\
16.0\end{array}$ & $\begin{array}{l}2461 . \\
2528 . \\
2596 . \\
2638 . \\
2643 . \\
2637 .\end{array}$ & $\begin{array}{l}0.0 \\
0.0 \\
0.0 \\
0.0 \\
0.0 \\
0.0\end{array}$ & $\begin{array}{l}0.0 \\
0.0 \\
0.0 \\
0.0 \\
0.0 \\
0.0\end{array}$ & $\begin{array}{r}0 . \\
0 . \\
1 . \\
8: \\
9 .\end{array}$ & $\begin{array}{r}0.000 \\
0.000 \\
.100 \\
.050 \\
.050 \\
.100\end{array}$ & $\begin{array}{r}0.000 \\
0.000 \\
0.000 \\
30.000 \\
30.000 \\
30.000\end{array}$ & $\begin{array}{r}0 . \\
0 . \\
0 . \\
540 . \\
600 . \\
2100 .\end{array}$ \\
\hline
\end{tabular}

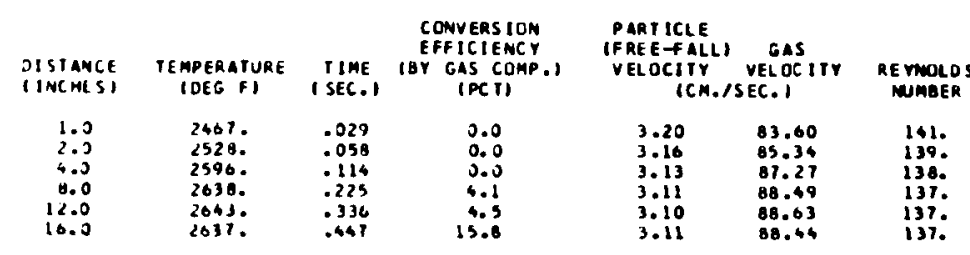

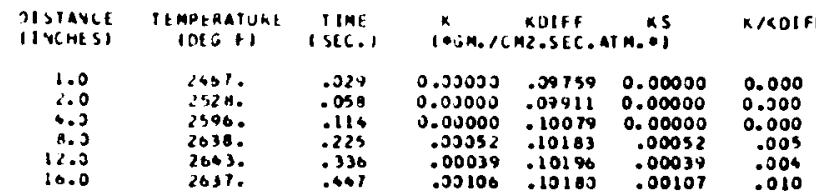


OROP TUBE FURMACE SYSTEM OATA REDUCTION MOCAAM

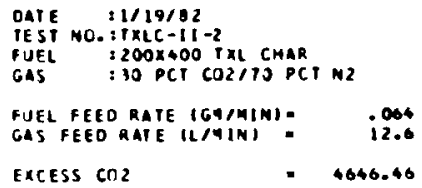

\begin{tabular}{|c|c|c|c|c|c|c|c|}
\hline $\begin{array}{l}\text { IS STAYCE } \\
\text { (INCHESI }\end{array}$ & $\begin{array}{l}\text { It MPERA TURE } \\
\text { POEG FI }\end{array}$ & $\begin{array}{l}\text { MOIS IURE } \\
\text { IN CHAR } \\
\text { (PCT) }\end{array}$ & $\begin{array}{l}\text { ASH IN } \\
\text { CHAR } \\
\text { IPCI }\end{array}$ & $\underset{\mid \max }{\operatorname{pop} \mid}$ & $\begin{array}{l}02 \\
(P(T)\end{array}$ & $\cos _{(\infty)}$ & CO \\
\hline $\begin{array}{r}1.0 \\
2.0 \\
4.0 \\
8.0 \\
12.0 \\
16.0\end{array}$ & $\begin{array}{l}1848 . \\
1873 . \\
1878 . \\
1070 . \\
1939 . \\
1998 .\end{array}$ & $\begin{array}{l}0.0 \\
0.0 \\
0.0 \\
0.0 \\
0.0 \\
0.0\end{array}$ & $\begin{array}{l}0.0 \\
0.0 \\
0.0 \\
0.0 \\
0.0 \\
0.0\end{array}$ & $\begin{array}{l}0 . \\
0 . \\
0: \\
0 . \\
0 . \\
0 .\end{array}$ & $\begin{array}{l}0.000 \\
0.000 \\
0.000 \\
0.000 \\
0.000 \\
0.000\end{array}$ & $\begin{array}{l}30.000 \\
30.000 \\
30.000 \\
30.000 \\
30.000 \\
30.000\end{array}$ & $\begin{array}{r}0 . \\
0 . \\
0 . \\
50 . \\
80 . \\
600 .\end{array}$ \\
\hline
\end{tabular}

\begin{tabular}{|c|c|c|c|c|c|c|}
\hline $\begin{array}{l}\text { DI SIANCE } \\
\text { (INCHESI) }\end{array}$ & $\begin{array}{l}\text { TE MPER A TURE } \\
\text { IOEG FI }\end{array}$ & $\begin{array}{l}\operatorname{l} \operatorname{limE} \\
\text { I SEC.I }\end{array}$ & $\begin{array}{l}\text { CONVERSION } \\
\text { EFFICIENCY } \\
\text { (BY GAS COMP.) } \\
\text { IPCII }\end{array}$ & $\begin{array}{l}\text { PART ICLE } \\
\text { IF REE FALLI } \\
\text { VELOCITY } \\
\text { ICH.I }\end{array}$ & $\begin{array}{l}\text { GAS } \\
\text { VELOCITY } \\
\text { SEC. }\end{array}$ & $\begin{array}{l}\text { REYMOLD } \\
\text { MUMER }\end{array}$ \\
\hline $\begin{array}{r}1.0 \\
2.0 \\
4.0 \\
8.0 \\
12.0 \\
16.0\end{array}$ & $\begin{array}{l}1848 . \\
1873 . \\
1878 . \\
1870 . \\
1939 . \\
1998 .\end{array}$ & $\begin{array}{l}.053 \\
.105 \\
.209 \\
.418 \\
.021 \\
.819\end{array}$ & $\begin{array}{l}0.0 \\
0.0 \\
0.0 \\
.4 \\
. .6\end{array}$ & $\begin{array}{l}3.14 \\
3.12 \\
3.12 \\
3.13 \\
3.00 \\
3.04\end{array}$ & $\begin{array}{l}45.14 \\
45.63 \\
45.72 \\
45.57 \\
46.92 \\
40.08\end{array}$ & $\begin{array}{l}159 . \\
130 . \\
158 . \\
150 . \\
156 . \\
154 .\end{array}$ \\
\hline
\end{tabular}

\begin{tabular}{|c|c|c|c|c|c|c|}
\hline $\begin{array}{l}\text { DISIAANCE } \\
\text { (INCHESI }\end{array}$ & $\begin{array}{l}\text { TEMPERATURE } \\
\text { (OEG FI }\end{array}$ & $\begin{array}{l}\text { TIME } \\
\text { ( SEC.) }\end{array}$ & $\underset{\left.1 * G M_{0}\right)}{K}$ & $\begin{array}{l}\text { XOIFF } \\
\text { A2.SEC. }\end{array}$ & $\begin{array}{r}k S \\
m . * i)\end{array}$ & $x<1<01$ \\
\hline $\begin{array}{r}1.0 \\
2.0 \\
6.0 \\
8.0 \\
12.0 \\
16.0\end{array}$ & $\begin{array}{l}1848 . \\
1873 . \\
1878 . \\
1870 \\
1939 . \\
1998 .\end{array}$ & $\begin{array}{l}.053 \\
.105 \\
.209 \\
.418 \\
.821 \\
.819\end{array}$ & $\begin{array}{r}0.00000 \\
0.00000 \\
0.00000 \\
.00003 \\
.00003 \\
.00019\end{array}$ & $\begin{array}{l}.08166 \\
.00232 \\
.08244 \\
.08224 \\
.00606 \\
.08561\end{array}$ & $\begin{array}{r}0.00000 \\
0.00000 \\
0.00000 \\
.00003 \\
.00003 \\
.00019\end{array}$ & $\begin{array}{l}0.000 \\
0.000 \\
0.000 \\
.000 \\
.000 \\
.002\end{array}$ \\
\hline
\end{tabular}

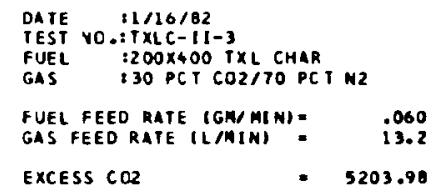

\begin{tabular}{|c|c|c|c|c|c|c|c|}
\hline $\begin{array}{l}\text { OISI ANCE } \\
\text { (INCHESI) }\end{array}$ & $\begin{array}{l}\text { TEMP ERATURE } \\
\text { (DEG F) }\end{array}$ & $\begin{array}{l}\text { MOI S TURE } \\
\text { IN CHAR } \\
\text { IPCT) }\end{array}$ & $\begin{array}{l}\text { A SH IN } \\
\text { CMAR } \\
\text { IPCII }\end{array}$ & $\begin{array}{l}\text { NOX } \\
\text { (PPAN) }\end{array}$ & (PCT) & $\begin{array}{c}\mathrm{CO} 2 \\
\text { (PCT) }\end{array}$ & $\begin{array}{l}\text { CO } \\
\text { IPPYI }\end{array}$ \\
\hline $\begin{array}{r}1.0 \\
2.0 \\
4.0 \\
8.0 \\
12.0 \\
16.0\end{array}$ & $\begin{array}{l}2110 . \\
2136 . \\
2175 . \\
2213 . \\
2231 . \\
2219 .\end{array}$ & $\begin{array}{l}0.0 \\
0.0 \\
0.0 \\
0.0 \\
0.0 \\
0.0\end{array}$ & $\begin{array}{l}0.0 \\
0.0 \\
0.0 \\
0.0 \\
0.0 \\
0.0\end{array}$ & $\begin{array}{l}0 . \\
0 . \\
0 . \\
0 . \\
0 . \\
1 .\end{array}$ & $\begin{array}{l}0.000 \\
0.000 \\
0.000 \\
0.000 \\
0.000 \\
0.000\end{array}$ & $\begin{array}{l}30.000 \\
30.000 \\
30.000 \\
30.000 \\
30.000 \\
30.000\end{array}$ & $\begin{array}{r}0 . \\
60 . \\
192 . \\
1320 \\
2800 \\
4640\end{array}$ \\
\hline
\end{tabular}

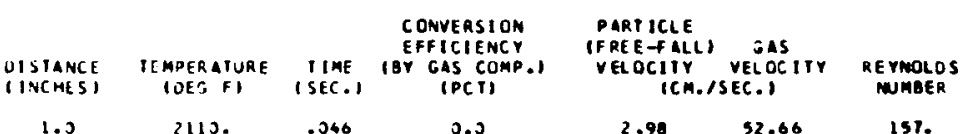

\begin{tabular}{|c|c|c|c|c|c|c|}
\hline $\begin{array}{r}1.0 \\
2.0 \\
6.0 \\
8.0 \\
12.0 \\
16.0\end{array}$ & $\begin{array}{l}2110 . \\
2136 . \\
2115 . \\
2213 . \\
2239 . \\
2219 .\end{array}$ & $\begin{array}{l}.066 \\
.091 \\
.180 \\
.353 \\
.531 \\
.707\end{array}$ & $\begin{array}{r}0.5 \\
: 5 \\
11.8 \\
11.7 \\
25.5 \\
39.2\end{array}$ & & $\begin{array}{l}2.98 \\
2.96 \\
2.94 \\
2.92 \\
2.91 \\
2.92\end{array}$ & $\begin{array}{l}52.68 \\
53.18 \\
33.98 \\
54.76 \\
55.25 \\
54.88\end{array}$ \\
\hline $\begin{array}{l}\text { ISIANCE } \\
\text { IVCHESI }\end{array}$ & $\begin{array}{c}\text { IEMHEAATURE } \\
\text { IJEG FI }\end{array}$ & $\begin{array}{l}\text { IIME } \\
\text { I SEC.) }\end{array}$ & $\stackrel{x}{\left.\log M_{0}\right)}$ & $\begin{array}{l}\text { KDIfF } \\
\text { M2.SEC.AT }\end{array}$ & $\begin{array}{r}k S \\
m .01\end{array}$ & $K /<0|f|$ \\
\hline $\begin{array}{l}1.3 \\
2.0 \\
4.0 \\
9.3 \\
12.0 \\
10.3\end{array}$ & $\begin{array}{l}2119 . \\
2136 . \\
2175 . \\
2139 \\
22310 \\
2219 .\end{array}$ & $\begin{array}{l}.046 \\
.091 \\
.180 \\
.356 \\
.531 \\
.101\end{array}$ & $\begin{array}{r}0.00000 \\
.00017 \\
.00027 \\
.00097 \\
.00149 \\
.00184\end{array}$ & $\begin{array}{l}.08852 \\
.09918 \\
.09011 \\
.07115 \\
.091111 \\
.39131\end{array}$ & $\begin{array}{l}0.00020 \\
.00011 \\
.00027 \\
.00098 \\
.00152 \\
.00108\end{array}$ & $\begin{array}{l}0.000 \\
.002 \\
.003 \\
.011 \\
.016 \\
.020\end{array}$ \\
\hline
\end{tabular}


OROP TUBE FURNACE SYSTEM DATA REDUCTICN PROGRAM

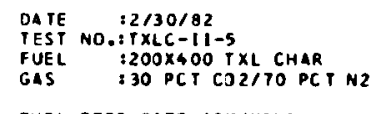

FUEL FEED RATE (GN/MIN]:
GAS FEEDRATE (L/MINI)

EXCESS CO2

- 5863.80

DISTAVCE
IINCHESI

TEMPERATURE
(DEG F)
2467.
2528.
2596.
2638.
2643.
2637.

MOISTURE ASH IN

IPCT)

(PCT)

NOX 02

$\begin{array}{llll}0.0 & 0.0 & 0 . & 0.000 \\ 0.0 & 0.0 & 0 . & 0.000\end{array}$

$\begin{array}{lllll}0.0 & 0.0 & 0 . & 0.000 & 30.000 \\ 0.0 & 0.0 & 1 . & 0.000 & 30.000\end{array}$

$\begin{array}{lllll}0.0 & 0.0 & 1 . & 0.000 & 30.000 \\ 0.0 & 0.0 & 9.0 & 0.000 & 30.000 \\ 0.0 & 0.0 & 9.000 & 30.000 \\ 0.0 & 0.0 & 9.000 & 30.000\end{array}$

CONVERSION
EFFICIENCY PARTICLE
(FREE-FALL) GAS

EFFICIENCY (FREE-FALL) GAS

DISTANCE TEMPERATURE
(INGHESI (DEG FI

TIME, COY GAS COMP.

1.0
2.0
4.0
8.0
12.0
16.0

$\begin{array}{ll}2467 . & .038 \\ 2528 . & .076\end{array}$

2528.

$2630 . \quad-293$

2637 .

0.0
1.2
8.3
46.5
60.6
75.7

ICM.ISEC.I

DISTANCE TEMPERATURE
IINCHESI TOEG FI

(OEG FI TIME

1.0

2467.

SEC.
.038

2467.
2528.
2596.

2643 . $\quad .436$

$\begin{array}{ll}2.79 & 64.06 \\ 2.76 & 65.40 \\ 2.73 & 66.88 \\ 2.71 & 67.81\end{array}$

67.81
67.92

NUMBER

$\begin{array}{rl}4.0 & 2638 . \\ 8.0 & 2643 .\end{array}$

.076
.149
.293
.436

$\mathbb{R}_{0 \mathrm{CM}}$ ROIFF

K/KOI FF

$\begin{array}{lll}0.00000 & .09759 & 0.0 \\ .00045 & .09911 & \end{array}$

.00164 .10079

$\begin{array}{lll}.00547 & .10183 & .00578 \\ .00520 & .10196 & .00548\end{array}$

0.00000
.00045

.00045
.00167

0.000
.005

.016

.00551 .10180 .00582

158.

…

153.$$
\text { .054 }
$$ 
APPENDIX D

CHAR COMBUSTION/GASIFICATION MODEL

The computer model formulated by Combustion Engineering, Inc., to simulate plugflow char combustion or gasification in the DTFS, was based on kinetic expressions derived by Field and co-workers at BCURA ( $\underline{9})$. This particular model was chosen because the laminar-flow DTFS satisfies the plug-flow requirements whereby the reaction products are time-resolved along the furnace distance.

This model is versatile enough to take into account certain parameter changes, such as the percentage of excess $\mathrm{O}_{2}$ (for combustion) or $\mathrm{CO}_{2}$ (for gasification), anisothermal temperature profile in the reaction zone, particle size distributions, and reaction mechanism factor. Reaction rates are governed by diffusional and surface reaction rate coefficients, depending on particle size and temperature.

The program is written in general terms for predicting pulverized coal combustion or gasification in the DTFS. It is discussed as such, although the special precautions taken for char combustion or gasification will be explained in the course of this discussion.

The basic model formulation is as follows. First, a definition of symbols is given.

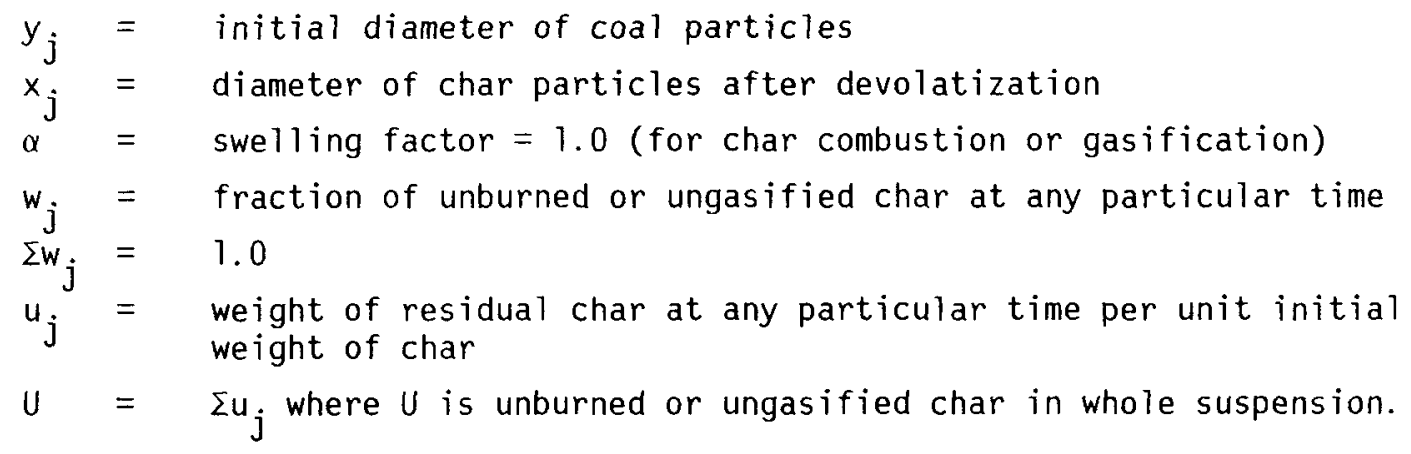


The rate of change of weight fraction $u_{j}$ is given by:

$$
d u_{j} / d t=-s_{j} q_{j}
$$

where $S_{j}=$ geometric surface area of each particular fraction per unit weight of initial char, $\left(\mathrm{cm}^{2} / \mathrm{g}\right)$, and

$\mathrm{q}_{\mathrm{j}}=$ rate of carbon removal per unit surface area, $\left(\mathrm{g} / \mathrm{cm}^{2}-\mathrm{sec}\right)$

Assuming spherical particles

$$
s_{j}=\left(6 w_{j} \alpha^{2}\right) /\left(c_{f} \rho_{f} y_{f}\right)
$$

where $C_{f}$ is a fraction of moisture and ash-free fuel after devolatilization

$\left(C_{f}=1\right.$ for char combustion or gasification $)$

$\rho_{f}$ is apparent density of moisture and ash-free fuel, $\left(\mathrm{g} / \mathrm{cm}^{3}\right)$

$$
q_{j}=\left[P_{g}(U)\right] /\left(1 / K_{D I F F}+1 / K_{S}\right)
$$

$K_{\text {DIFF }}$ is diffusional reaction rate coefficient, $\left(\mathrm{g} / \mathrm{cm}^{2}-\mathrm{sec}-\mathrm{atm}\right)$, and

$$
K_{D I F F}=\left(\begin{array}{lll}
24 & \emptyset & D
\end{array}\right) /\left(R^{\prime} T X_{j}\right)
$$

where $\emptyset$ is mechanism factor, defined as the ratio of moles of carbon consumed to moles of reactant gas transported to the surface.

$R^{\prime}$ is gas constant, (82.06 atm $-\mathrm{cm}^{3} \cdot / \mathrm{mole}^{\left.-{ }^{\circ} \mathrm{K}\right)}$

$T$ is gas temperature, $\left({ }^{\circ} \mathrm{K}\right)$

$D$ is binary diffusion coefficient at 1 atm. for $\mathrm{O}_{2}-\mathrm{N}_{2}$ medium (Combustion) or $\mathrm{CO}_{2}-\mathrm{N}_{2}$ medium (gasification), $\left(\mathrm{cm}^{2} / \mathrm{sec}\right)$

$\mathrm{K}_{\mathrm{s}}$ is surface reaction rate coefficient, $\left(\mathrm{g} / \mathrm{cm}^{2}-\mathrm{sec}\right)$

$$
K_{S}=A \exp (-E / R T)
$$

where $E$ is activation energy, (cal/mole)

$R$ is gas constant, $\left(1.986 \mathrm{cal} / \mathrm{mole}^{\circ} \mathrm{K}\right)$

$A$ is frequency factor, $\left(\mathrm{g} / \mathrm{cm}^{2} \mathrm{sec}\right.$. atm.)

$P_{g}(U)$ is a function of oxygen concentration (combustion) or carbon dioxide concentration (gasification) 


$$
P_{g}(U)=[(c U+e) /(1+e)]\left(P_{0}\right)
$$

where $\mathrm{c}=\frac{\mathrm{O}_{2}\left(\text { or } \mathrm{CO}_{2}\right) \text { required to burn (or gasify) char from raw fuel }}{\mathrm{O}_{2}\left(\text { or } \mathrm{CO}_{2}\right) \text { required to burn (or gasify) raw fuel }}$

$(c=1.0$ for char combustion or gasification)

e is excess oxygen (combustion) or carbon dioxide (gasification)

$\mathrm{P}_{\mathrm{O}}$ is initial partial pressure of $\mathrm{O}_{2}$ in combustion medium or $\mathrm{CO}_{2}$ in gasification medium.

Assuming constant particle density and burning or gasifying from the outside, this leads to the final equation form:

$$
d u_{j} / d t=-\left[\left(u_{j} / w_{j}\right)^{2 / 3} S_{j} P_{g}(U)\right] /\left[\left(u_{j} / w_{j}\right)^{1 / 3} / K_{D I F F}+1 / K_{S}\right]
$$

Equation (D-7) represents a series of differential equations for all particle sizes for each fraction. The only variables are time, particle size distribution of each fraction, oxygen or carbon dioxide concentration, and the physical properties of the fuet.

A sample of a typical run is given for PSC char gasfication in 0.3 carbon dioxide atmosphere (in nitrogen balance) at $2650^{\circ} \mathrm{F}$.

$\underline{\text { INPUT }}$

1. Particle size distribution of $200 \times 400$ mesh feed char having a Rosin-Rammler dispersion index of 7.1 . The representation of such a distribution by 10 monosize fractions is shown in the computer output.

2. Swelling factor $(\alpha)$ : 1.0 (for char combustion or gasification).

3. Apparent density $\left(\rho_{f}\right): 1.0 \mathrm{~g} / \mathrm{cm}^{3}$ (dry-ash-free basis).

4. Fraction of moisture and ash-free char remaining after devolatilization $\left(C_{f}\right): 1.0$ (for char combustion or gasification).

5. $\mathrm{CO}_{2}$ required to gasify char $/ \mathrm{CO}_{2}$ required to gasify coal (c): 1.0 (for char combustion or gasification). 
6. Temperature Profile (see output).

7. Excess $\mathrm{CO}_{2}: 28.4$

8. $\mathrm{CO}_{2}$ Partial Pressure $\left(\mathrm{P}_{0}\right): 0.30 \mathrm{~atm}$

9. Mechanism Factor $(\emptyset): 1.0$

10. Activation Energy (E): $53700 \mathrm{cal} / \mathrm{mole}$

11. Frequency Factor $(A): 1390 \mathrm{~g} / \mathrm{cm}^{2}-\mathrm{sec}-\mathrm{atm}$

12. Gasification Mode: Shrinking core

\section{OUTPUT}

The terms used in the output are explained as follows:

PSAD: $\quad$ Particle size diameter, $(\mathrm{cm})$

KDIFF: Diffusional reaction rate coefficient, $\left(\mathrm{g} / \mathrm{cm}^{2}-\mathrm{sec}-\mathrm{atm}\right)$

SI : Particle geometric surface area, $\left(\mathrm{cm}^{2} / \mathrm{g}\right)$

WF : Fractional weight in each size cut

PARTICLES: Number of particles

Values of the above terms are the average values per size fraction

KS: $\quad$ Surface reaction rate coefficient, $\left(\mathrm{g} / \mathrm{cm}^{2} \mathrm{sec}\right.$. atm. $)$.

CC: Percent carbon in the char

SIZE FRACTION OF CHAR GASIFIED OFF: An "o" indicates incompleteness of gasification of a given size fraction. A "numerical value" indicates completeness of gasification of a given size fraction. 
MATHEMATICAL MODELS

OF PULVERIZED CGIAL GASIFICATION IN UTFS

EST NO.: PSCC-I1-5

FLIEL: $200 \times 400 M$ PSC CHAR

GAS: 3OPCT CO2 + 7OPCT NE

\begin{tabular}{lllll} 
PSAD & KDIFF & \multicolumn{1}{l}{ SI } & WF & PARTICLES \\
.0040 & .1249 & 78.34 & .0512 & $.1545 E+07$ \\
.0044 & .1143 & 114.55 & .0818 & $.1892 E+07$ \\
.0047 & .1053 & 154.01 & .1193 & $.2161 E+07$ \\
.0051 & .0977 & 186.95 & .1562 & $.2256 E+07$ \\
.0055 & .0911 & 199.18 & .1785 & $.2089 E+07$ \\
.0058 & .0853 & 179.04 & .1713 & $.1647 E+07$ \\
.0062 & .0802 & 128.76 & .1310 & $.1048 E+07$ \\
.0066 & .0757 & 69.19 & .0746 & $.5013 E+06$ \\
.0069 & .0717 & 25.48 & .0290 & $.1654 E+06$ \\
.0073 & .0080 & 5.78 & .0069 & $.3383 E+05$
\end{tabular}

ks

co:

$.000083 \quad 84.68$

$\begin{array}{cccc}\text { TIME(SEC) } & \begin{array}{c}\text { FRACTION OF } \\ \text { CHAR UNGASIFIED }\end{array} & \begin{array}{c}\text { PRETIAL } \\ \text { PRESSURE }\end{array} & \begin{array}{c}\text { CF } \\ \text { TEMPERATURE } \\ \text { (DEG K) }\end{array} \\ .0890 & .9986 & .3000 & 1626.0 \\ .1390 & .9965 & .3000 & 1665.4 \\ .1890 & .9938 & .2999 & 1690.1 \\ .2390 & .9908 & .2999 & 1702.8 \\ .2890 & .9876 & .2999 & 1710.9 \\ .3390 & .9841 & .2998 & 1718.9 \\ .3890 & .9805 & .2998 & 1721.8 \\ .4390 & .9770 & .2998 & 1722.8 \\ .4890 & .9734 & .2997 & 1723.8 \\ .5390 & .9698 & .2997 & 1723.0 \\ .5890 & .9663 & .2997 & 1721.6 \\ .0390 & .9628 & .2996 & 1720.3\end{array}$

TOTAL GASIFICATION EFFICIENCY

1.54

1.75

2.01

2.31

2.63

2.97

3.32
3.67

4.03

4.38

5.06
SIZE FRACTION OF PCT. C CHAR GASIFIED IN ASH

0000000000094.60 $0 \begin{array}{llllllllll}0 & 0 & 0 & 0 & 0 & 0 & 0 & 0 & 0 & 0.84 .64\end{array}$

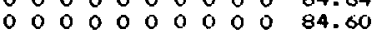

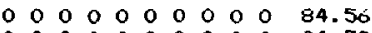
$\begin{array}{llllllllllll}0 & 0 & 0 & 0 & 0 & 0 & 0 & 0 & 0 & 0 & 84.52\end{array}$

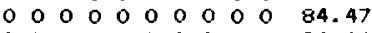
$0 \begin{array}{lllllllllll}0 & 0 & 0 & 0 & 0 & 0 & 0 & 0 & 0 & 0 & 84.43\end{array}$ $\begin{array}{llllllllllll}0 & 0 & 0 & 0 & 0 & 0 & 0 & 0 & 0 & 0 & 84.38\end{array}$ $\begin{array}{lllllllllll}0 & 0 & 0 & 0 & 0 & 0 & 0 & 0 & 0 & 0 & 84.33\end{array}$ $\begin{array}{llllllllllll}0 & 0 & 0 & 0 & 0 & 0 & 0 & 0 & 0 & 0 & 84.28\end{array}$

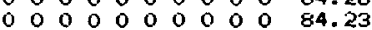

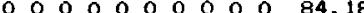

UNGASIFIED SIZE FRACTION

.0487

.0781

.1143

.1501

.1720

.1268

CAREON IN EACH SIZE FRACIION
84.07

84.12

84.16

84.20

84.23

84.25

E

\section{ALFHA}

PPCO2

ExCO2

c

1.00

.3000

28.4000

1.0000

1390. 53700 .
TEMP

PHI

1 .
1720.
.0723

84.28

CF

.9840
.028

94. 30

TIMI

.04
.0067

84.32

TIMET

.60

GASIFICATION MODE : SHRINKING LOFE 